\title{
Water-Resources Investigations in Wisconsin, 2000
}

Open-File Report 00-251

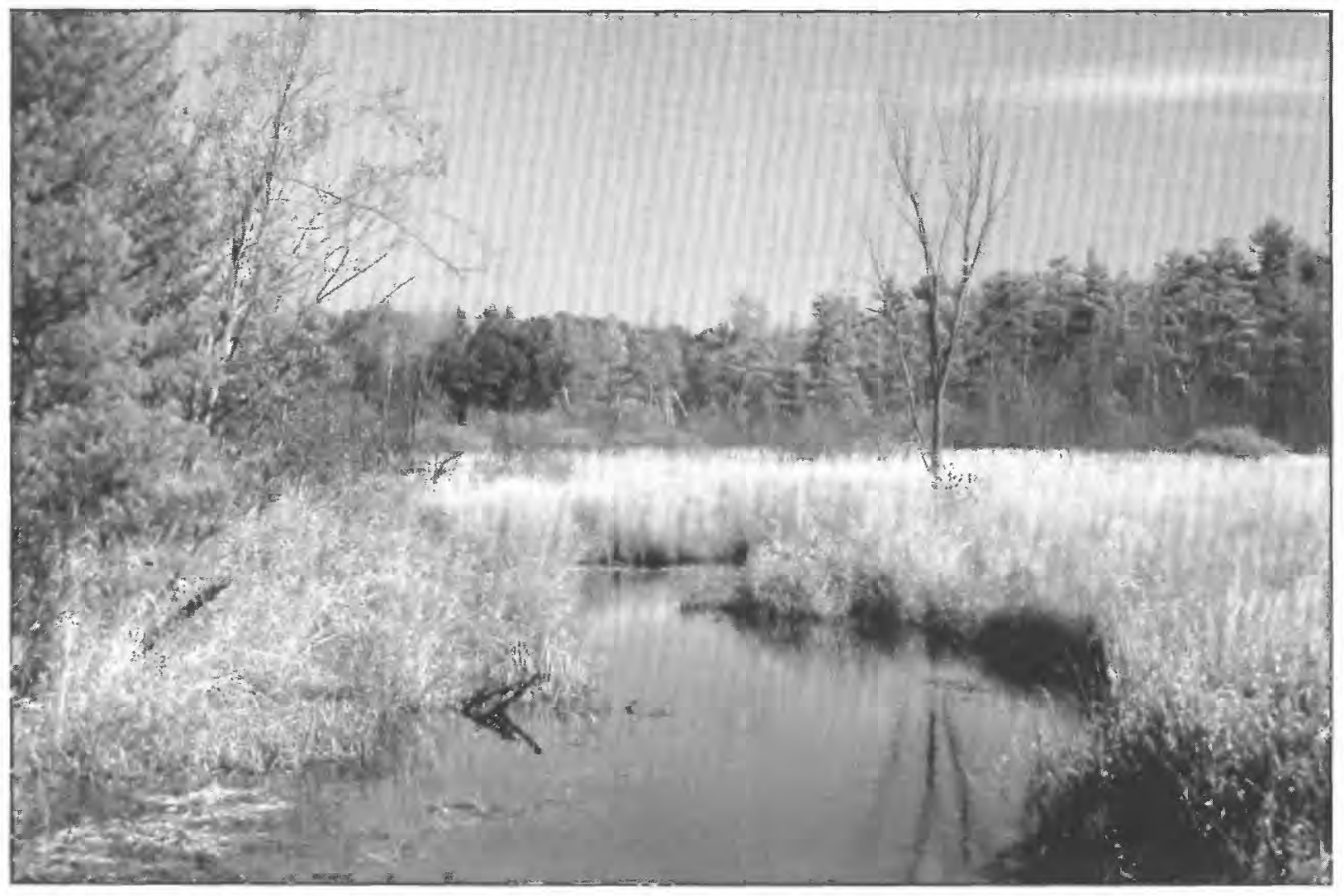

Tomorrow River, Portage County 



\section{WATER-RESOURCES INVESTIGATIONS IN WISCONSIN, 2000}

Compiled by D.E. Maertz

U.S. GEOLOGICAL SURVEY

Open-File Report 00-251

Middleton, Wisconsin

2000 


\title{
U.S. DEPARTMENT OF THE INTERIOR \\ BRUCE BABBIT, Secretary
}

\author{
U.S. GEOLOGICAL SURVEY \\ Charles G. Groat, Director
}

For additional information write to:

District Chief

U.S. Geological Suvey

8505 Research Way

Middleton, WI 53562
Copies of this report can be purchased from:

U.S. Geological Survey

Branch of Information Services

P.O. Box 25286

Denver, CO 80225-0286

Wisconsin District WRD home page: http:/ / wi.water.usgs.gov/

Wisconsin Real-Time Water Data: http://wi.water.usgs.gov/rt-cgi/gen_tbl_pg

Wisconsin Ground Water page: http://wi.water.usgs.gov/gw/

USGS home page: http://www.usgs.gov/ 


\section{CONTENTS}

Program

Basic data collection

Page

$00100 \quad$ Collection of basic records-surface water ....................................................

$00200 \quad$ Collection of basic records-ground water .......................................................... 10

$00201 \quad$ Crandon ground water...............................................................................12

$00302 \quad$ Collection of basic records-Dane County program ............................................13

00303 Interagency methods and data comparability board (MDCB) ..............................14

00304 Age dating ground water in atrazine prohibition areas in Wisconsin.....................15

$00351 \quad$ Ground-water age dating in the Little Plover River Basin, Wisconsin.....................16

$00400 \quad$ Collection of basic records-sediment ..............................................................17

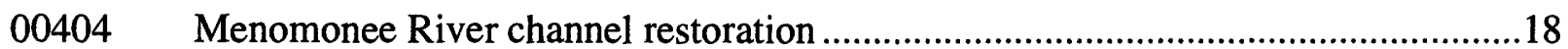

$00700 \quad$ Wisconsin water-use data file .................................................................... 19

Interpretive studies

10900 Regional flood-frequency study for urban and rural streams in Wisconsin ............20

$12301 \quad$ Menominee trace element monitoring ................................................................23

12303 Compilation and analysis of water-resources data near the

St. Croix Reservation, Wisconsin ...........................................................24

12306 Oneida Nation hydrologic investigations.........................................................25

12309 Bedrock aquifer characterization, northern Bad River Indian Reservation.............26

12312 Delineation of the area of ground-water contribution and the times of travel to community water systems on the Menominee Indian Reservation ...................27

13300 Lake water-quality monitoring, chemical and biological monitoring of

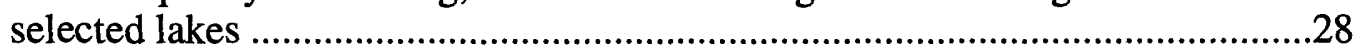

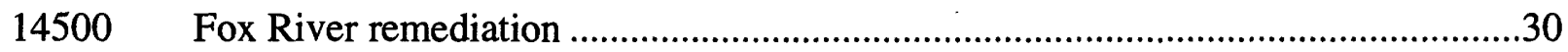

16400 Technical and field support for U.S. Environmental Protection Agency, Region V32

17202-04, Trends in water quality and stream habitat for priority watersheds..........................33

17213

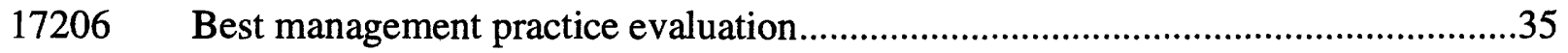

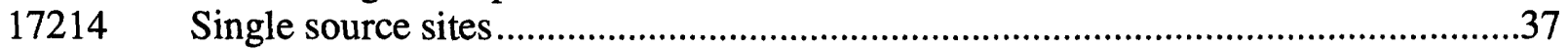

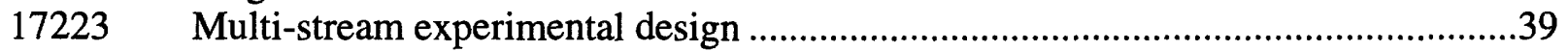

17229 Hydrology and water quality of three pastures in southwestern Wisconsin ............40

$17230 \quad$ Bridge scour on Balsam Road bridge ...............................................................42

17231 Evaluating improved street sweeping for enhancing water quality in highway runoff in Milwaukee

17232 Quantification of solids loading from residential and commercial construction sites in Dane County, Wisconsin ..............................................................44

17233 Evaluation of the effectiveness of urban conservation design practices..................45

17234 Temperature modeling of urban stormwater runoff...............................................46

17235 Impacts of residential construction on stream water quality ..............................47

$17236 \quad$ Rock River phosphorus..............................................................................48

17301 Assessment of the hydrology and water quality of, and phosphorus loading to, Pike Lake in Washington County .............................................................49

17302 Miscellaneous monitoring associated with lakes .............................................50

17303 Wisconsin lakes, Green Lake tributary monitoring .............................................51

$17304 \quad$ Pool 8 ground-water/surface-water study ....................................................52

$17305 \quad$ Hydrologic investigation of Silver Lake .....................................................53

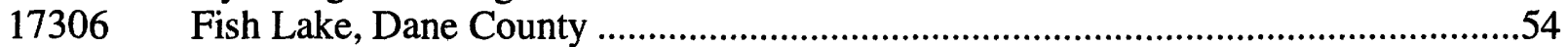




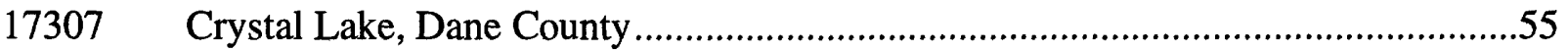

17310 Lauderdale Lakes restoration monitoring ......................................................56

17313 Assessment of phosphorus loading, winter anoxia, and stage regulation of Little St. Germain Lake, Vilas County ...........................................................57

17314 Assessment of the water quality, hydrology, and biology of Geneva Lake .............58

17317 Determination of streamflow, phosphorus, and solids loads at three sites above Sinissippi Lake in Dodge County ......................................................................59

$17319 \quad$ Middle Genesee Lake ground-water study ..........................................................6

17400 Western Lake Michigan drainages National Water-Quality Assessment

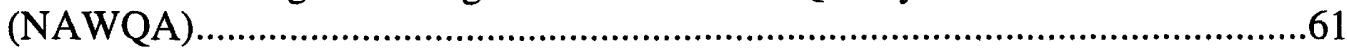

17402 Upper Illinois River Basin National Water-Quality Assessment (NAWQA) ..........63

17406 Technical assistance in the development of regional nutrient criteria for the nation.

17500 Hydrologic and biogeochemical budgets in temperate lakes and their watersheds, northern Wisconsin

18101 Assessment of the hydrology, water quality, and biology of Delavan Lake .............68

$18300 \quad$ Lake Michigan tributary loading ..........................................................................70

18301 Trace-metal loading to Lakes Michigan and Superior............................................72

18900 Dane County regional hydrologic study ..............................................................73

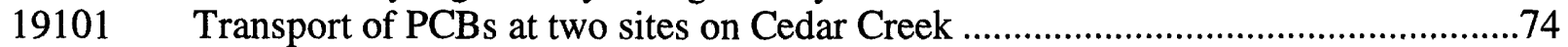

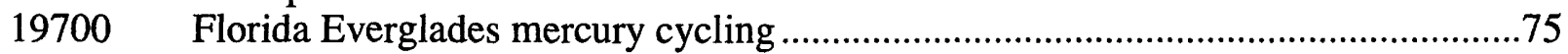

20200, Mitigation of future North Fork urbanization impacts on the Pheasant

20202-03 Branch hydrologic system........................................................................76

20201 Mitigation of future impacts of urbanization on the Badger Mill Creek

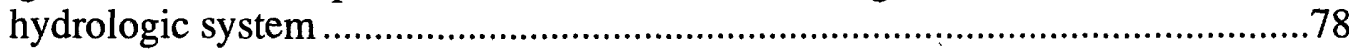

20400 Monitoring and evaluation of the impacts of aircraft and runway deicers on the Kinnickinnic River surface-water resources ............................................79

20500 Modeling the effects of the Crandon Mine using the HSPF watershed model.........81

20501 Developing a Geographic Information System and relational database of HSPF and FEMWATER layers used in modeling efforts related to the proposed

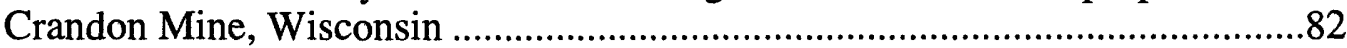

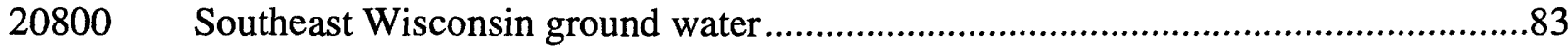

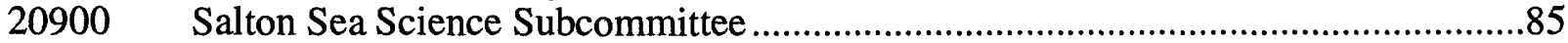

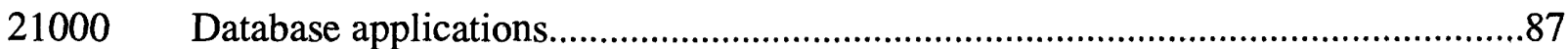

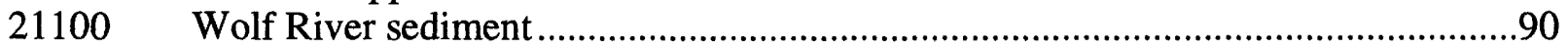

21200, St. Croix National Scenic Riverway - nutrient and sediment loading and

$21202 \quad$ long-term water-quality monitoring...................................................................91

21300 St. Croix National Scenic Riverway - nutrient and sediment loading, waterquality monitoring and assessment partnership ...................................................93

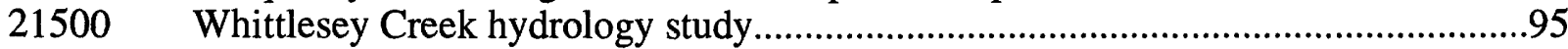

21600 Sources of cryptosporidium in watersheds ...........................................................96

21700 Historical ecosystem reconstruction and potential identification of effects of past ecosystem perturbations in Lac Courte Oreilles............................................98

21800 The effect of near-shore development on constituent loading to lakes in

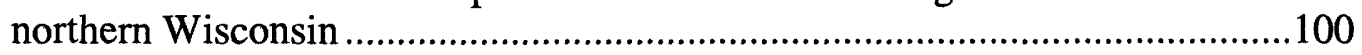

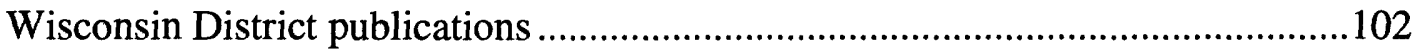

Wisconsin District personnel ...........................................................................116 


\section{ILLUSTRATIONS}

Page

Figure 1. Organization chart of the U.S. Geological Survey, Water Resources Division, Wisconsin District. viii

2. Location of offices in the Wisconsin District ix

3. Funding sources for the water-resources program in Wisconsin for the 2000 fiscal year. xi

4. 1999 runoff as percent of long-term average runoff xii

5. Comparison of annual discharge at representative gaging stations to the long-term average discharge for water years 1916-99. xiii

6. Comparison of discharge at representative gaging stations during water year 1998 with discharge for 1916-99. xiv

7. Relation of seasonal water-table levels to long-term means. xviii

8. Location of continuous-record data-collection stations .5

9. Location of network observation wells 11

10. Location of crest-stage-gage data-collection stations 22 


\section{BASIC MISSION AND PROGRAMS}

\section{U.S. Geological Survey}

The U.S. Geological Survey was established by an act of Congress on March 3, 1879, to provide a permanent Federal agency to conduct the systematic and scientific "classification of the public lands, and examination of the geological structure, mineral resources, and products of national domain." An integral part of that original mission includes publishing and disseminating the earthscience information needed to understand, to plan the use of, and to manage the Nation's energy, land, mineral, and water resources.

Since 1879, the research and fact-finding role of the U.S. Geological Survey (USGS) has grown and has been modified to meet the changing needs of the Nation it serves. As part of the evolution, the USGS has become the Federal Government's largest earth-science research agency, the Nation's largest civilian map-making agency, the primary source of data on the Nation's surfacewater and ground-water resources, and the employer of the largest number of professional earth scientists in the Nation. Today's programs serve a diversity of needs and users. Programs include:

Conducting detailed assessments of the energy and mineral potential of land and offshore areas.

Investigating and issuing warnings of earthquakes, volcanic eruptions, landslides, and other geologic and hydrologic hazards.

Conducting research on the geologic structure of land and offshore areas.

Studying the geologic features, structure, processes, and history of the other planets of our solar system.

Conducting topographic surveys and preparing topographic and thematic maps and related cartographic products.

Developing and producing digital cartographic data bases and products.

Collecting data on a routine basis to determine the quantity, quality, and use of surface water and ground water.

Conducting water-resource appraisals to describe the consequences of alternative plans for developing land and water resources.

Conducting research in hydraulics and hydrology, and coordinating all Federal water-data acquisition.

Using remotely sensed data to develop new cartographic, geologic, and hydrologic research techniques for natural resources planning and management.

Providing earth-science information through an extensive publications program and a network of public access points.

Along with its continuing commitment to meet the growing and changing earth-science needs of the Nation, the USGS remains dedicated to its original mission to collect, analyze, interpret, publish, and disseminate information about the natural resources of the Nation-providing "Earth science in the public service." 


\section{Water Resources Division}

The mission of the Water Resources Division (WRD) is to provide the hydrologic information and understanding needed for the optimum utilization and management of the Nation's water resources for the overall benefit of the people of the United States. This mission is accomplished, in large part, through cooperation with other Federal and non-Federal agencies, by:

Collecting, on a systematic basis, data needed for the continuing determination and evaluation of the quantity, quality, and use of the Nation's water resources.

Conducting analytical and interpretive water-resource appraisals describing the occurrence, availability, and physical, chemical, and biological characteristics of surface water and ground water.

Conducting supportive basic and problem-oriented research in hydraulics, hydrology, and related fields of science to improve the scientific basis for investigations and measurement techniques and to understand hydrologic systems sufficiently well to quantitatively predict their response to stress.

Disseminating the water data and the results of these investigations and research through reports, maps, computerized information services, and other forms of public releases.

Coordinating the activities of Federal agencies in the acquisition of water data for streams, lakes, reservoirs, estuaries, and ground water.

Providing scientific and technical assistance in hydrologic fields to other federal, state, and local agencies, to licensees of the Federal Energy Regulatory Commission, and to international agencies on behalf of the U.S. Department of State. 


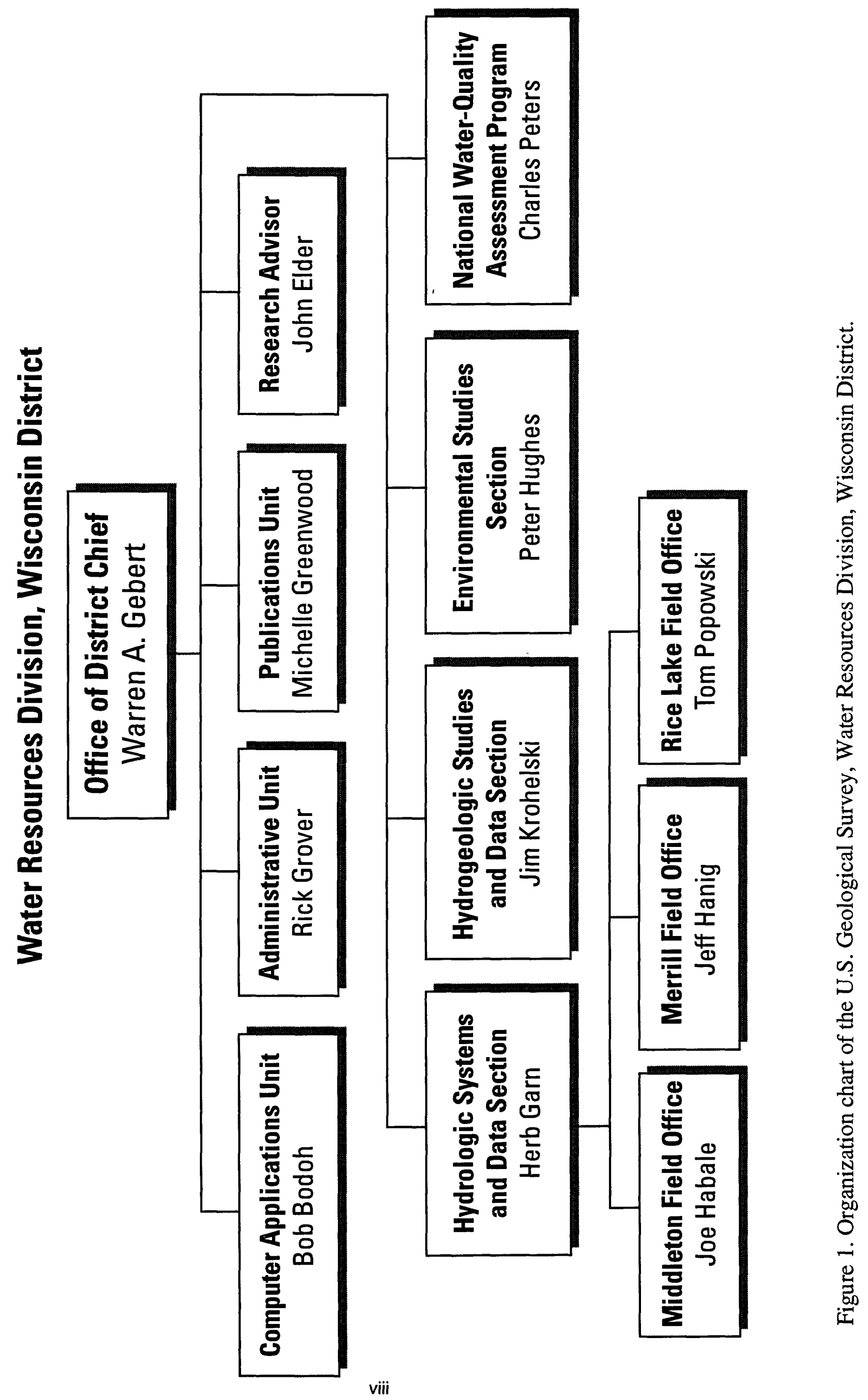




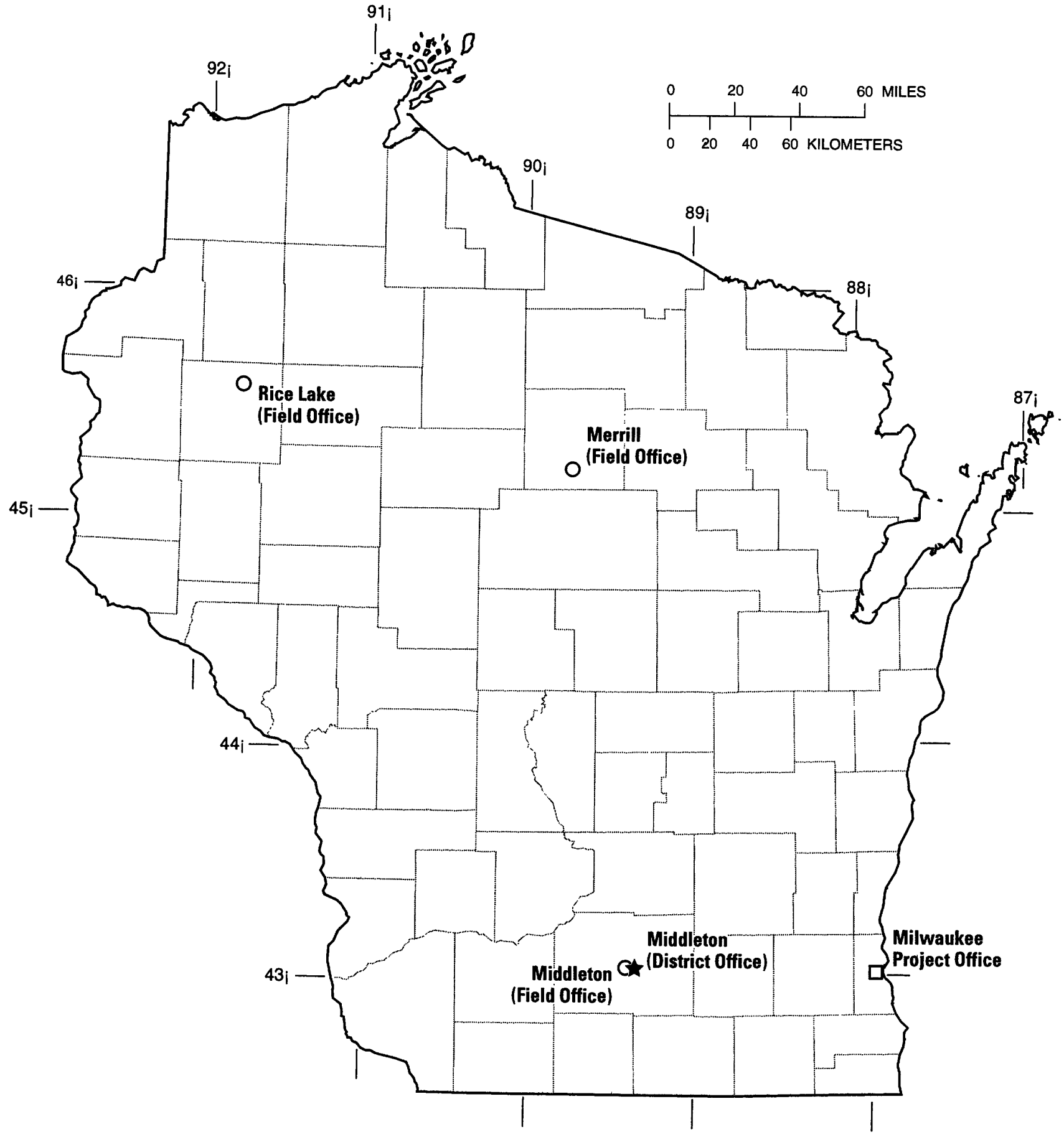

Figure 2. Location of offices in the Wisconsin District. 


\section{COOPERATORS}

\section{State Agencies}

Illinois Department of Transportation

Kickapoo Reserve

University of Wisconsin, Madison

University of Wisconsin, Stevens Point

Wisconsin Department of Agriculture, Trade, and Consumer Protection

Wisconsin Department of Natural Resources

Wisconsin Department of Transportation

Wisconsin Geological and Natural History Survey

Wisconsin State Laboratory of Hygiene

\section{Local Agencies}

City of Barron

City of Beaver Dam

City of Brookfield

City of Fond du Lac

City of Fort Atkinson

City of Hillsboro

City of Madison

City of Middleton

City of Milwaukee

City of Peshtigo

City of Sparta

City of Thorp

City of Waupun

County of Bayfield

County of Milwaukee

Dane County Lakes and Watershed Management

Dane County Land Conservation Department

Dane County Regional Planning Commission

Dane County Department of Planning \& Development

Fontana/Walworth Water Pollution Control Commission

Geneva Lake Environmental Agency

Green Bay Metropolitan Sewerage District

Madison Metropolitan Sewerage District

Marathon County Highway Department

Rock County Public Works Department

Rock River Watershed POTW

Southeastern Wisconsin Regional Planning Commission

St. Croix County Land Conservation Department

Village of Wittenberg

Walworth County Metropolitan Sewerage District

\section{Other Federal Agencies}

U.S. Army Corps of Engineers,

Detroit District

Rock Island District

St. Paul District

Vicksburg, MS

\author{
Other Federal Agencies (continued) \\ Federal Energy Regulatory Commission licensees \\ Black River Falls Municipal Utilities \\ Consolidated Paper Corporation, Niagara Division \\ Dairyland Power Cooperative \\ Northern States Power Company \\ Northwoods Hydropower \\ Wisconsin Electric Power Company \\ Wisconsin Public Service Corporation \\ Wisconsin Valley Improvement Company \\ National Park Service \\ U.S. Environmental Protection Agency
}

\author{
Indian Tribes \\ Bad River Band of Lake Superior Chippewa \\ Lac Courte Oreilles Tribe \\ Lac du Flambeau Band of Lake Superior Chippewa \\ Menominee Indian Tribe of Wisconsin \\ Oneida Tribe of Indians of Wisconsin \\ St. Croix Tribe of Wisconsin \\ Stockbridge-Munsee Band of Mohican Indians
}

\section{Lake Districts}

Benedict/Tombeau Lake Management District

Buffalo Lake District

City of Muskego

Eagle Spring Lake Management District

Green Lake Sanitary District

Lauderdale Lakes Lake Management District

Little Cedar Lake Protection and Rehabilitation District

Little Green Lake Protection and Rehabilitation District

Little Muskego Lake Management District

Little St. Germain Protection and Rehabilitation District

Middle Genesee Lake District

Okauchee Lake District

Pike Lake Management District

Potter Lake Rehabilitation and Protection District

Powers Lake District

Silver Lake Protection and Rehabilitation District

Whitewater Rice Lake Management District

Wind Lake Management District

Town of Delavan

Town of Hubbard

Town of Sand Lake

Town of Wascott

Village of Oconomowoc Lake 


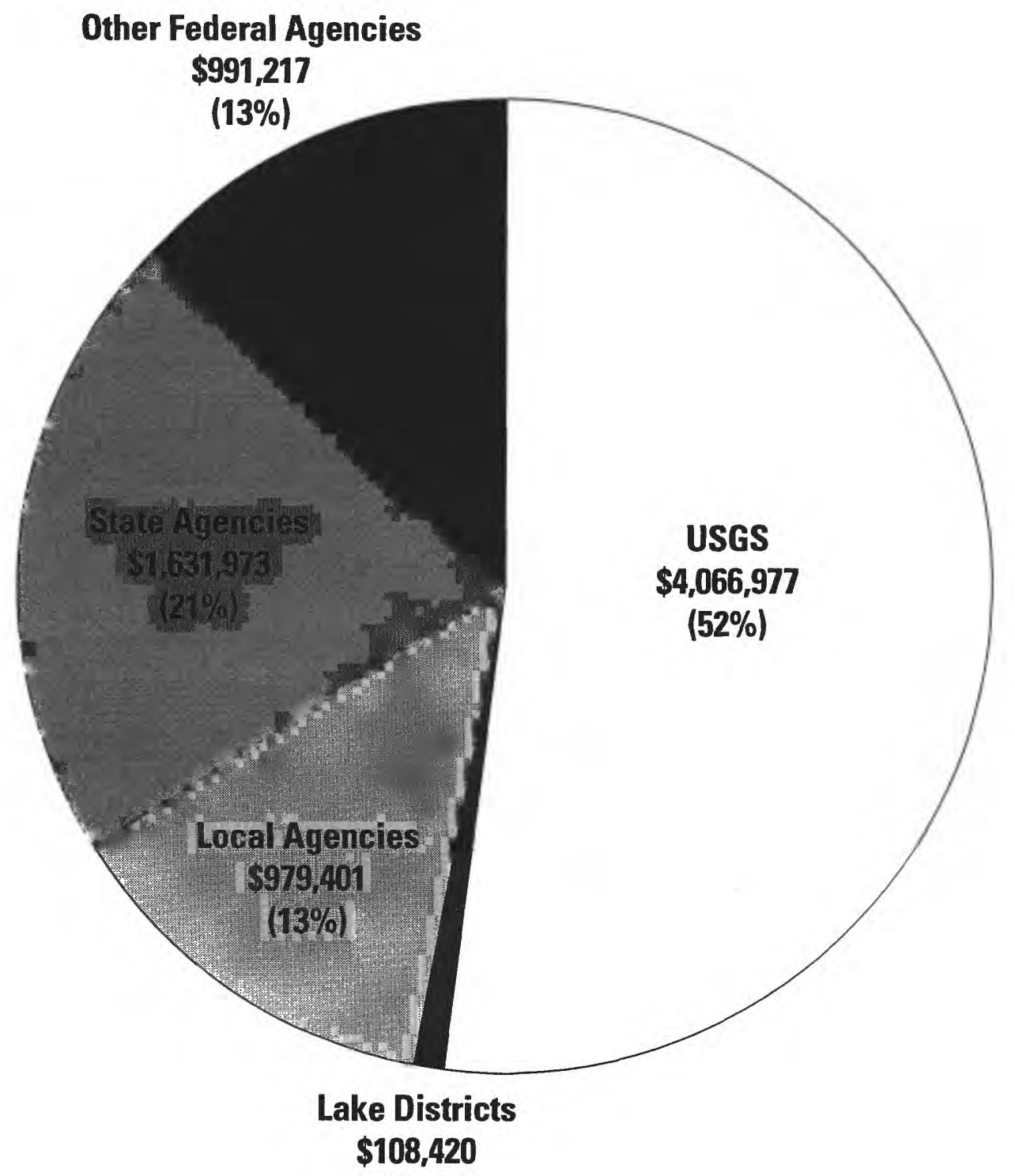

$(1 \%)$

\section{Total Funding $=\$ \mathbf{7}, 777,988$}

Figure 3. Funding sources for the water-resources program in Wisconsin for the 2000 fiscal year. 


\section{SUMMARY OF HYDROLOGIC CONDITIONS}

\section{Streamflow}

The statewide average precipitation of 36.00 inches for the 1999 water year was 4.35 inches greater than the normal annual precipitation of 31.65 inches for water years 1961-90. Average precipitation values ranged from 83 percent of normal at both the Rosholt 9 NNE weather station in north central Wisconsin and Shawano 2 SSW WWTP weather station in northeast Wisconsin to 155 percent of normal at the Solon Springs weather station in northwestern Wisconsin (from tables provided by JoAnne Kruepke, UW-Extension, Wisconsin Geological and Natural History Survey, written commun., 2000).

Runoff differed for rivers throughout the State and ranged from 46 percent in east central Wisconsin to 157 percent in south central Wisconsin. Runoff was lowest (46 percent of the average annual runoff from 1989-99) for the Duck Creek near Oneida station and highest (157 percent of the average annual runoff from 1949-69, 1988-99) for the South Branch Rock River at Waupun station in south central Wisconsin. Departures of runoff in the 1999 water year as a percent of long-term average runoff in the State (determined using stations with drainage areas greater than 150 square miles and at least 20 years of record) are shown in Figure 4.
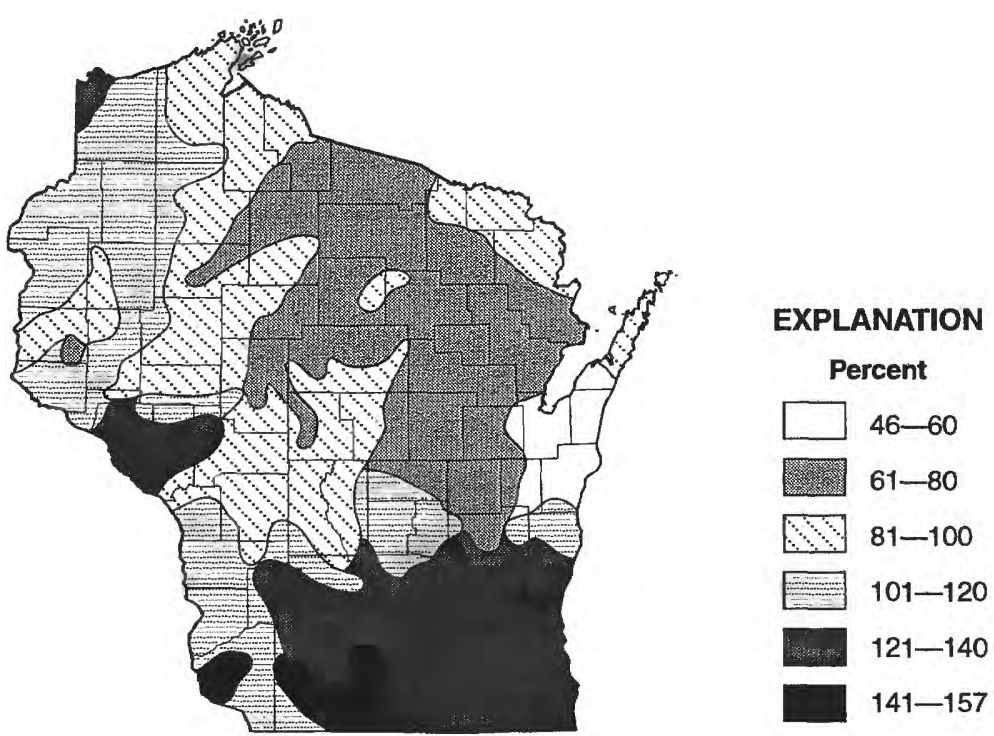

Figure 4. 1999 runoff as percentage of long-term average runoff.

Annual discharges for the individual water years (1916-99) at the Oconto River near Gillett, Jump River at Sheldon, and Sugar River near Brodhead are shown in Figure 5. The comparison of monthly and annual discharges for the 1999 water year to discharge for an 84-year base period at the same three gaging stations is shown in Figure 6. 
05436500 SUGAR RIVER NEAR BRODHEAD

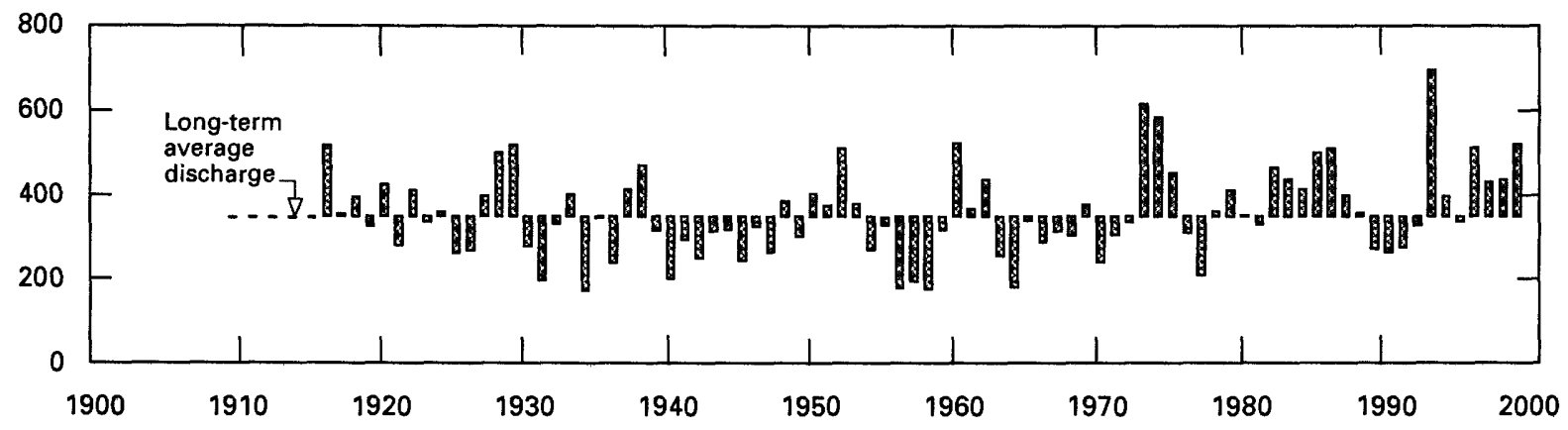

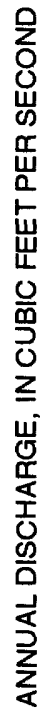

05362000 JUMP RIVER AT SHELDON

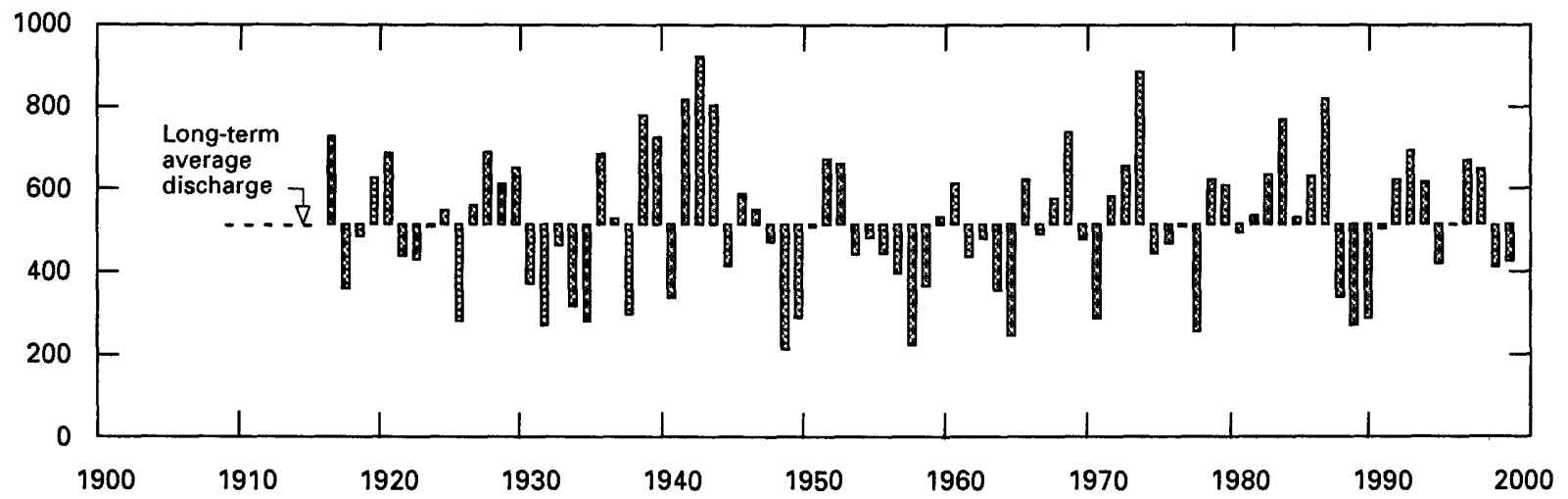

04071000 OCONTO RIVER NEAR GILLETT

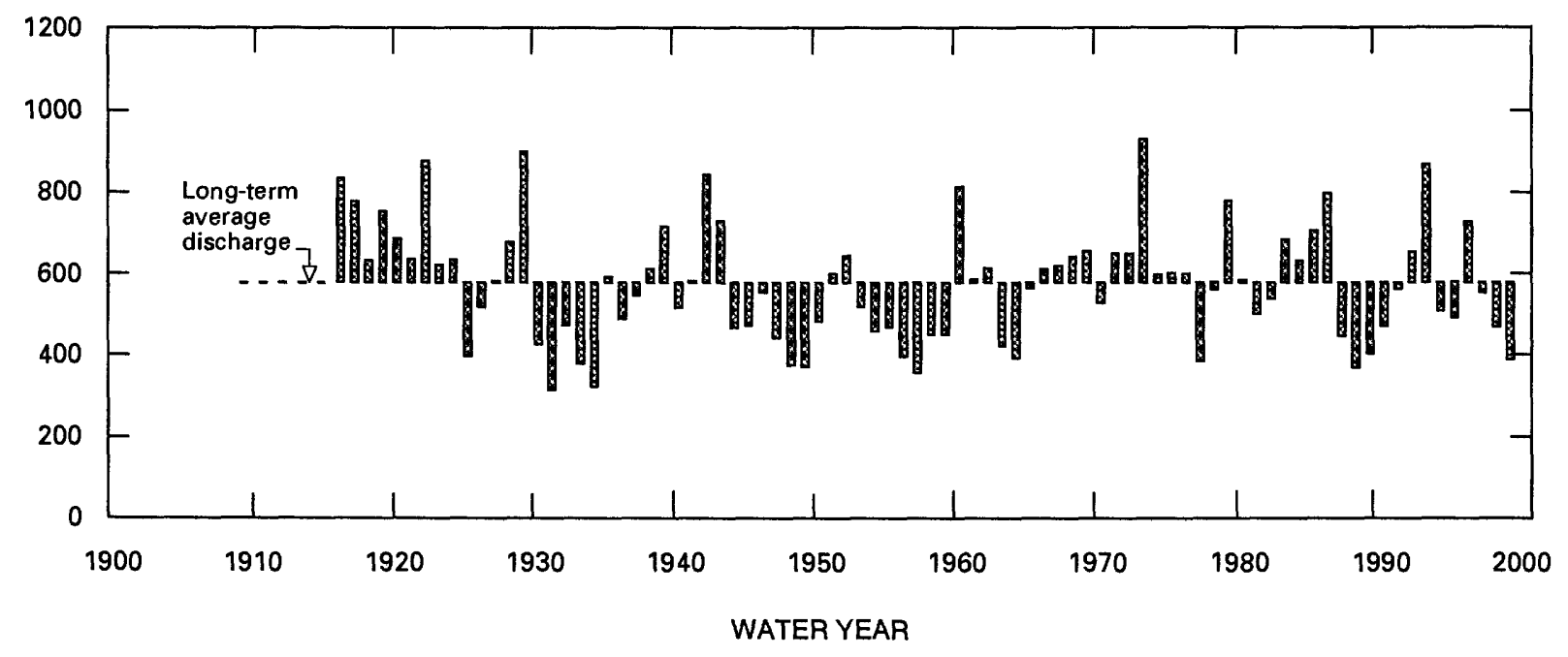

Figure 5. Comparison of annual discharge at representative gaging stations to their long-term average discharge for water years 1916-1999. 
05436500 SUGAR RIVER NEAR BRODHEAD DRAINAGE AREA: 523 SQUARE MILES
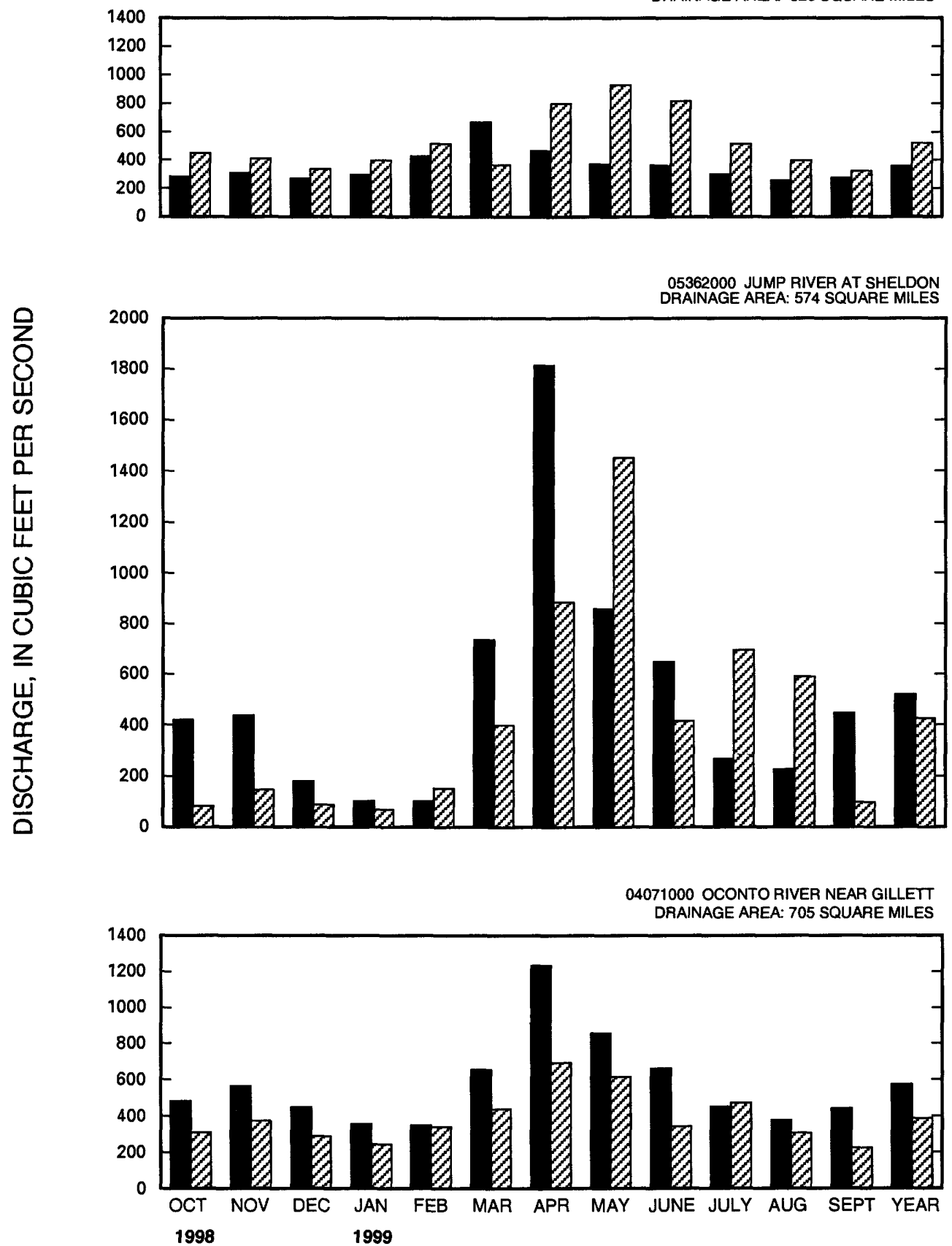

\section{EXPLANATION}

Long-term average monthly and long-term average annual discharge for 1916-1999

Monthly and annual discharge for 1999 water year

Figure 6. Comparison of discharge at representative gaging stations during water year 1999 with discharge for 1916-1999. 
Low flows occurred at 13 gaging stations where the annual minimum 7-consecutive day average flows (Q7) had recurrence intervals of 5 or more years. Precipitation was well below normal in the summer and early fall months of 1998 in northern Wisconsin (Holmstrom and others, 1999). This resulted in Q7 values which equalled or exceeded the 5-year recurrence interval at a number of stations in north central and northwestern Wisconsin in early October and December. Below normal precipitation totals in August and early September in east central and southeastern Wisconsin (from tables provided by JoAnne Kruepke, UW-Extension, Wisconsin Geological and Natural History Survey, written commun., 2000) also resulted in Q7 values equal to or greater than the 5-year recurrence interval for stations in that area. The Q7 values and recurrence intervals for 13 gaging stations that equalled or exceeded 5 years are listed in the following table:

\begin{tabular}{lllcc}
\hline $\begin{array}{l}\text { Station } \\
\text { number }\end{array}$ & Station name & Date & Q7 (ft3/s) & $\begin{array}{c}\text { Recurrence interval } \\
\text { (years) }\end{array}$ \\
\hline 04027500 & White River near Ashland & Dec. 18 & 135 & 5 \\
04074950 & Wolf River at Langlade & Dec. 21 & 179 & 6 \\
04085200 & Kewaunee River near Kewaunee & Sept. 6 & 8.7 & 5 \\
04087120 & Menomonee River at Wauwatosa & Sept. 5 & 8.7 & 5 \\
04087159 & Kinnickinnic River at South 11th Street & Jan. 1 & 3.7 & 10 \\
& at Milwaukee & & & 5 \\
04087204 & Oak Creek at South Milwaukee & Sept. 5 & 0.88 & 7 \\
04087220 & Root River near Franklin & Sept. 6 & 2.2 & 10 \\
04087240 & Root River at Racine & Sept. 9 & 2.2 & 32 \\
05360500 & Flambeau River near Bruce & Dec. 22 & 319 & 5 \\
05365500 & Chippewa River at Chippewa Falls & Dec. 21 & 1080 & 9 \\
05395000 & Wisconsin River at Merrill & Oct. 20 & 797 & 9 \\
05398000 & Wisconsin River at Rothschild & Oct. 21 & 1060 & 16 \\
05400760 & Wisconsin River at Wisconsin Rapids & Oct. 11 & 1070 & 5 \\
\hline
\end{tabular}

Runoff from rainfall caused flooding in Wisconsin in late April. Storms in mid-May, mid-June, and July also caused floods with discharges that equalled or exceeded those with a recurrence interval of 10 years (Krug and others, 1991). Heavy rains and isolated thunderstorms in April through July caused localized flooding in south central and southeastern Wisconsin. Thunderstorms in northern Wisconsin during the month of July caused flood damages. Isolated thunderstorms occurring in a short time period late on July 15 and early on July 16 caused road damages estimated to be $\$ 1.5$ million and damage to homes of about $\$ 80,000$ in Florence County (Wisconsin State Journal, July 17, 1999). The rainfall at Florence was 7.3 inches, and a recording station seven miles south of Florence recorded 5.1 inches (Wisconsin State Journal, July 16, 1999). The 7.3 inches at Florence exceeds the 100-year 24-hour precipitation value of about 6 inches for the Florence area (Huff and Angel, 1992). Thunderstorms in northwestern Wisconsin on July 26 produced rainfall amounts at many stations which exceeded 3 inches, and the largest recorded values of 5.60 inches at Solon Springs and 5.04 inches at Gordon (National Oceanic and Atmospheric Administration, July 1999) occurred in Douglas County. Governor Thompson requested Federal Emergency Management Agency assistance for flood damages in Bayfield, Douglas, Rusk, and Sawyer counties as a result of these storms in late July (Federal Emergency Management Agency, July 28, 1999). 
Peak discharges at 14 stations which had recurrence intervals that equalled or exceeded 10 years are summarized in the following table:

\begin{tabular}{lllcc}
\hline $\begin{array}{l}\text { Station } \\
\text { number }\end{array}$ & Station name & Date & $\begin{array}{c}\text { Peak discharge } \\
\text { (ft3/s) }\end{array}$ & $\begin{array}{c}\text { Recurrence interval } \\
\text { (years) }\end{array}$ \\
\hline 04024400 & Stony Brook near Superior & July 26 & 480 & 20 \\
04025200 & Pearson Creek near Maple & July 26 & 878 & 10 \\
04027200 & Pearl Creek at Grandview & July 8 & 406 & 10 \\
04064500 & Pine River near Florence & July 15 & 3260 & 11 \\
04087088 & Underwood Creek at Wauwatosa & July 21 & 3280 & $>100$ \\
04087100 & Honey Creek at Milwaukee & June 13 & 1040 & $>100$ \\
04087200 & Oak Creek near South Milwaukee & Apr. 23 & 910 & 35 \\
04087204 & Oak Creek at South Milwaukee & Apr. 23 & 1060 & 27 \\
04087250 & Pike Creek near Kenosha & Apr. 23 & 174 & 10 \\
05430175 & Yahara River near Fulton & May 17 & 2490 & 11 \\
05436200 & Gill Creek near Brooklyn & May 17 & 960 & $>100$ \\
05545200 & White River tributary near Burlington & June 13 & 354 & $>100$ \\
05545750 & Fox River near New Munster & June 15 & 4670 & 11 \\
05548150 & North Branch Nippersink Creek near Genoa City June 13 & 517 & $>100$ \\
\hline
\end{tabular}

References cited:

Federal Emergency Management Agency, July 28, 1999, Wisconsin Requests Damage Assessments: accessed July 30, 1999, at URL http://www.fema.gov/nwz99/wi0728.htm.

Holmstrom, B.K., Olson, D.L., and Ellefson, B.R., 1999, Water Resources Data-Wisconsin, Water Year 1998: U.S. Geological Survey Water-Data Report WI-98-1, p. 5.

Huff, Floyd A. and Angel, James R., 1992, Rainfall Frequency Atlas of the Midwest: Midwestern Climate Center Research Report 92-03, Bulletin 71, p. 89.

Krug, W. R., Conger, D. H., and Gebert, W. A., 1991, Flood-frequency Characteristics of Wisconsin Streams: U.S. Geological Survey Water-Resources Investigations Report 91-4128, 185 p.

National Oceanic and Atmospheric Administration, 1999, Climatological data, Wisconsin, July 1999, Vol. 104, Number 07, p. 9.

Wisconsin State Journal, Severe flooding damages highways: Madison, Wis., July 17, 1999. , Major roads still out in Florence County: Madison, Wis., July 16, 1999. 
Suspended-sediment yields were monitored at two stations for water year 1999. The suspended-sediment yield at the Grant River at Burton in southwestern Wisconsin was $318 \mathrm{tons} / \mathrm{mi}^{2}$ (tons per square mile), or 129 percent of the average annual yield for 1978-99. The suspended-sediment yield for Jackson Creek Tributary near Elkhorn in southeastern Wisconsin for water year 1999 was 65 tons/ $/ \mathrm{mi}^{2}$, which was 89 percent of the average annual yield for the period 1984-99. The total phosphorus yield for Jackson Creek Tributary was $353 \mathrm{lbs} / \mathrm{mi}^{2}$ (pounds per square mile), or 80 percent of the 1984-99 annual average.

\section{Ground-Water Levels}

Maps showing the seasonal ground-water trends for the year (fig. 7) are based on water-level data from 22 shallow-aquifer wells, each having at least 15 years of record. Water-level measurements from each well are grouped so that FALL consists of measurements from October through December 1998; WINTER consists of measurements from January through March 1999; SPRING consists of measurements from April through June 1999; and SUMMER consists of measurements from July through September 1999. Mean seasonal water levels were compared to the long-term mean seasonal water levels. The 1999 water level was considered normal if it was within one-half of the standard deviation on the long-term mean.

In general, shallow ground-water levels during the 1999 water year were normal to above normal for most of the wells in the State. Milwaukee and Kenosha Counties had below normal ground-water levels at the beginning of the water year, and these levels remained below normal for most of the water year. The large extent of normal and above-normal ground-water levels can be attributed to near normal rainfall during the 1999 water year and normal rainfall during the previous water year. 


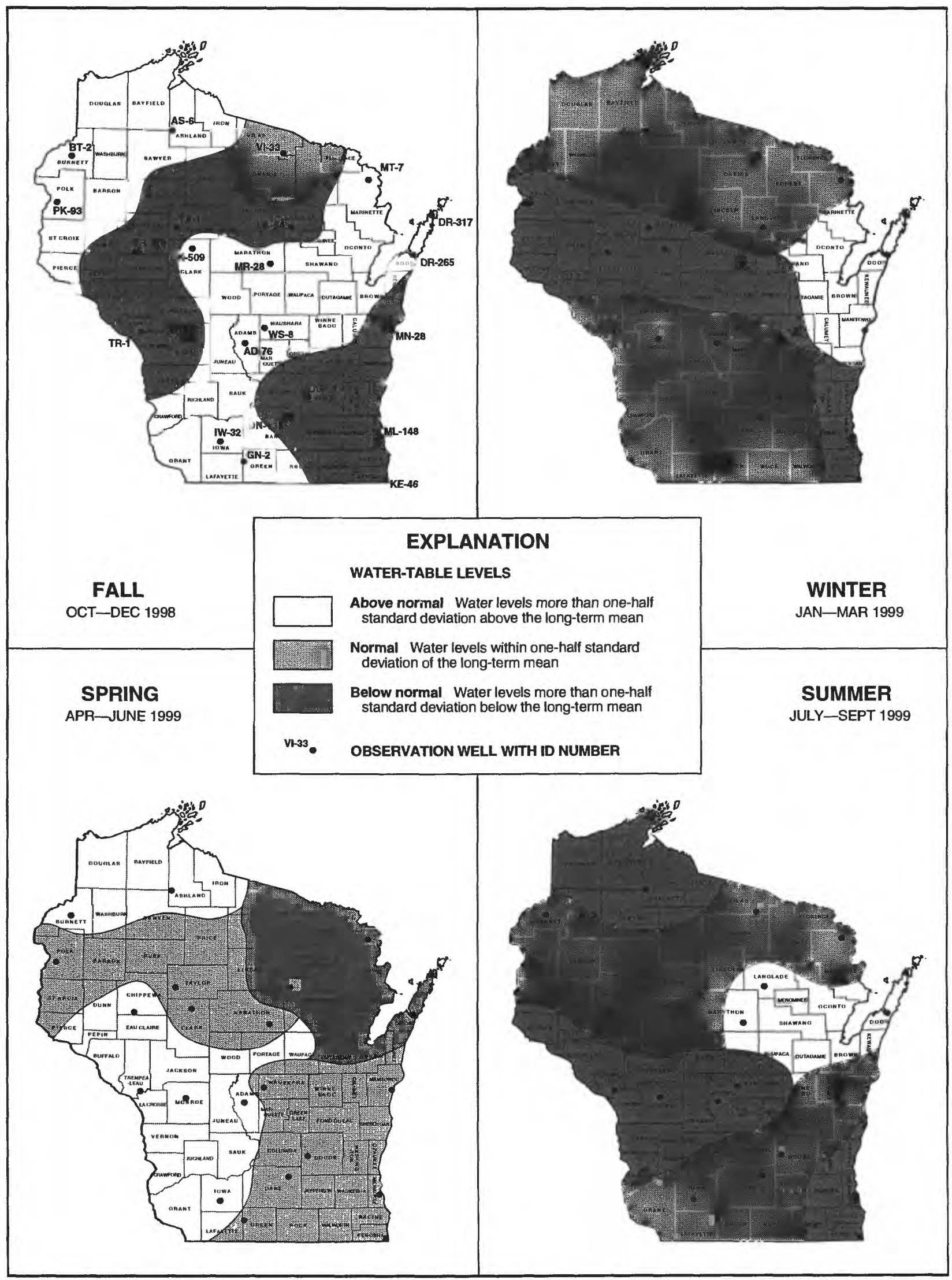

Figure 7. Relation of seasonal water-table levels to long-term means. 


\section{COLLECTION OF BASIC RECORDS-SURFACE WATER, WI 00100}

\section{COOPERATORS:}

Bad River Band of Lake Superior Chippewa Indians

City of Barron

City of Beaver Dam

City of Black River Falls

City of Brookfield

City of Fort Atkinson

City of Hillsboro

City of Peshtigo

City of Sparta

City of Thorp

City of Waupun

Dane County Department of Planning and Development

Dane County Regional Planning Commission

Federal (Regular)

Federal Energy Regulatory Commission Licensees

Consolidated Paper Corporation, Niagara Division

Dairyland Power Cooperative

Northern States Power Company

Northwoods Hydropower

Wisconsin Electric Power Company

Wisconsin Public Service Corporation

Wisconsin Valley Improvement Company

Fontana/Walworth Water Pollution Control Commission

Green Bay Metropolitan Sewerage District

Illinois Department of Transportation

Jefferson County

Kickapoo Reserve

Lac du Flambeau Band of Lake Superior Chippewa

Madison Metropolitan Sewerage District

Menominee Indian Tribe of Wisconsin

Oneida Tribe of Indians of Wisconsin

Rock County Public Works Department

Southeastern Wisconsin Regional Planning Commission Stockbridge-Munsee Band of Mohican Indians

U.S. Army Corps of Engineers

Village of Wittenberg

Walworth County Metropolitan Sewerage District

Wisconsin Department of Natural Resources

PROBLEM: Surface-water information is needed for surveillance, planning, design, hazard warning, operation, and management in water-related fields such as water supply, hydroelectric power, flood control, irrigation, bridge and culvert design, wildlife
LOCATION:

Statewide

PROJECT CHIEF:

Barry K. Holmstrom

PERIOD OF PROJECT:

July 1913-Continuing

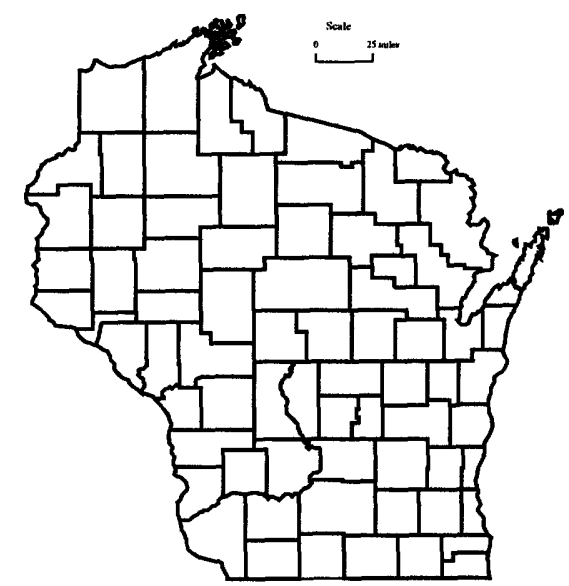


management, pollution abatement, flood-plain management, and water-resources development. An appropriate database is necessary to provide this information.

OBJECTIVE: The objectives of this study are to provide continuous discharge records for selected rivers at specific sites to supply the needs for regulation, analytical studies, definition of statistical properties, trends analysis, determination of the occurrence, and distribution of water in streams for planning. The project is also designed to determine lake levels and to provide discharge for floods, low-flow conditions, and for waterquality investigations. Requests for streamflow data and information relating to streamflow in Wisconsin are answered. Basic data are published annually in the report "Water Resources Data-Wisconsin".

APPROACH: A network of streamflow stations and lake-level stations will be maintained throughout Wisconsin. This includes operating the equipment at the gaging station to record river or lake stage, making periodic discharge measurements at each streamflow station to establish or verify a stage-discharge rating curve, reducing the stage records to instantaneous and daily discharges, compilation of monthly and annual discharges, and preparing data for publication in the annual report "Water Resources Data-Wisconsin".

Requests for streamflow data from other government agencies, consultants, and private parties will be processed.

PROGRESS (July 1999 to June 2000): During the current fiscal year, streamflow data were collected at a total of 110 sites: 18 sites for the Corps of Engineers, 14 sites for the Southeastern Wisconsin Regional Planning Commission, 10 sites for the Wisconsin Department of Natural Resources (WDNR), 8 sites for the Federal program, 4 sites for Federal Energy Commission licensees, 3 sites for the Madison Metropolitan Sewerage District, 3 sites for the Lac du Flambeau Band of Lake Superior Chippewa, and 1 site each for the Bad River Band of Lake Superior Chippewa Indians, Menominee Indian Tribe of Wisconsin, Oneida Tribe of Indians of Wisconsin, Stockbridge-Munsee Band of Mohican Indians, Illinois Department of Transportation, Rock County Public Works Department, Fontana/Walworth Water Pollution Control Commission, Dane County Department of Planning and Development, Walworth County Metropolitan Sewerage District, Dane County Regional Planning Commission, Green Bay Metropolitan Sewerage District, Kickapoo Reserve, and cities of Barron, Beaver Dam, Brookfield, Fort Atkinson, Hillsboro, Peshtigo, Sparta, Thorp, Waupun, and village of Wittenberg. Streamflow data were also collected at 28 sites for agencies working jointly with the USGS. Lakelevel data were collected at two sites for the Dane County Department of Planning and Development, two sites for the Corps of Engineers, one site for the Rock County Public Works Department, and one site for the WDNR.
A map showing the location of all continuous-record streamflow-gaging stations in Wisconsin is shown on page 5.

Computation of streamflow and lake-level records for all the network stations for the 1999 water year was completed, stored in our WATSTORE computer database, and published in the annual report "Water Resources Data-Wisconsin, water year 1999". More than 300 requests for streamflow information were answered.

PLANS (July 2000 to June 2001): Data will be collected at 114 continuous-streamflow stations (see the following list) and lake levels at 6 stations. Streamflow records will be computed and data published for the 2000 water year. Requests for streamflow information will be answered.

\section{Real-time data can be accessed on the World Wide Web at http://wi.water.usgs.gov}

Discharge data computation and publication is planned to be discontinued for 05369500 Chippewa River at Durand, 05379500 Trempealeau River at Dodge, 05381000 Black River at Neillsville, and 05382000 Black River near Galesville for the 2001 water year. Stage data only will be collected at these four stations. 


\section{SURFACE-WATER GAGING STATIONS EXPECTED TO BE OPERATED IN 2001 FY}

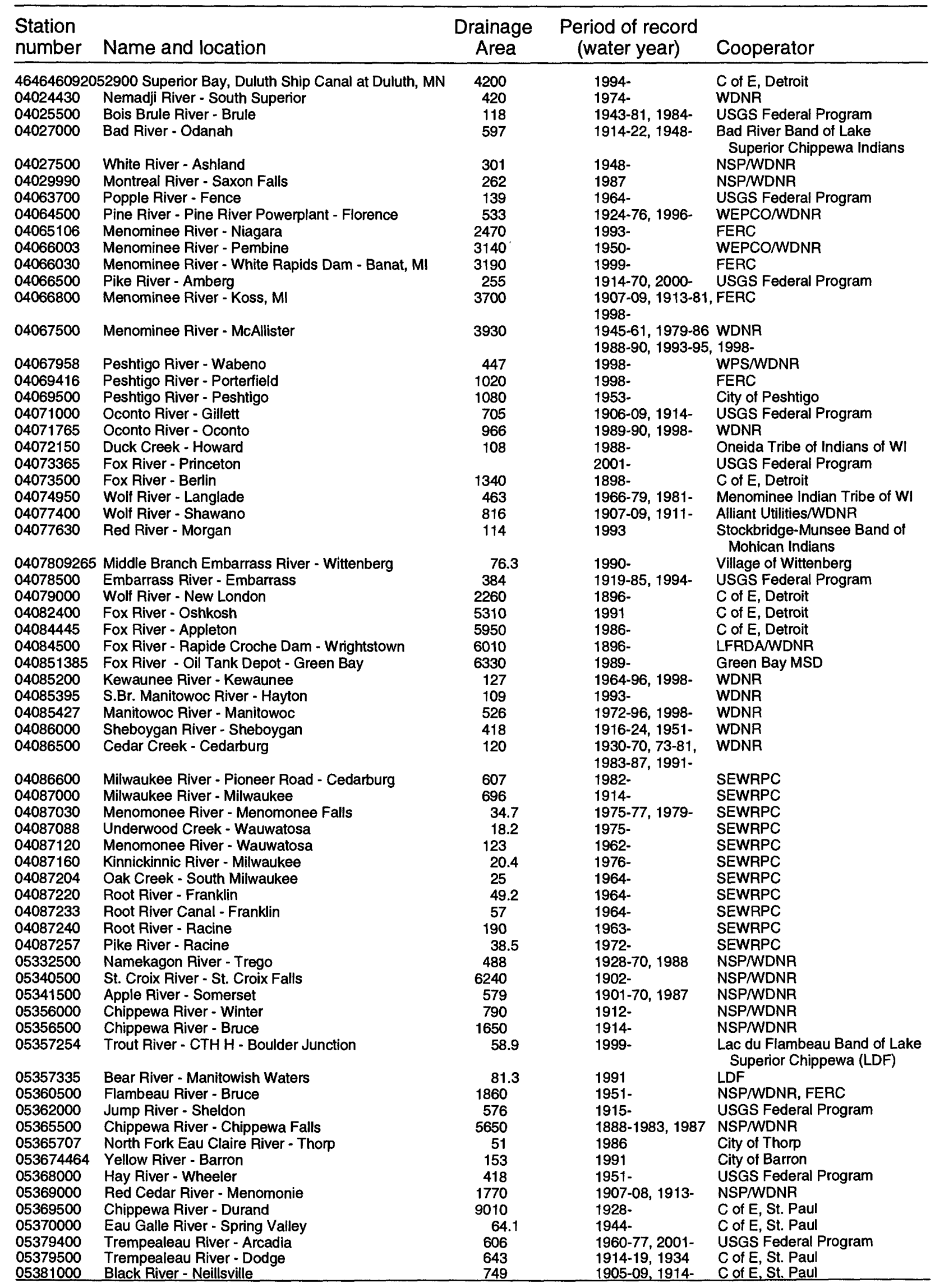


SURFACE-WATER GAGING STATIONS EXPECTED TO BE OPERATED IN 2001 FY

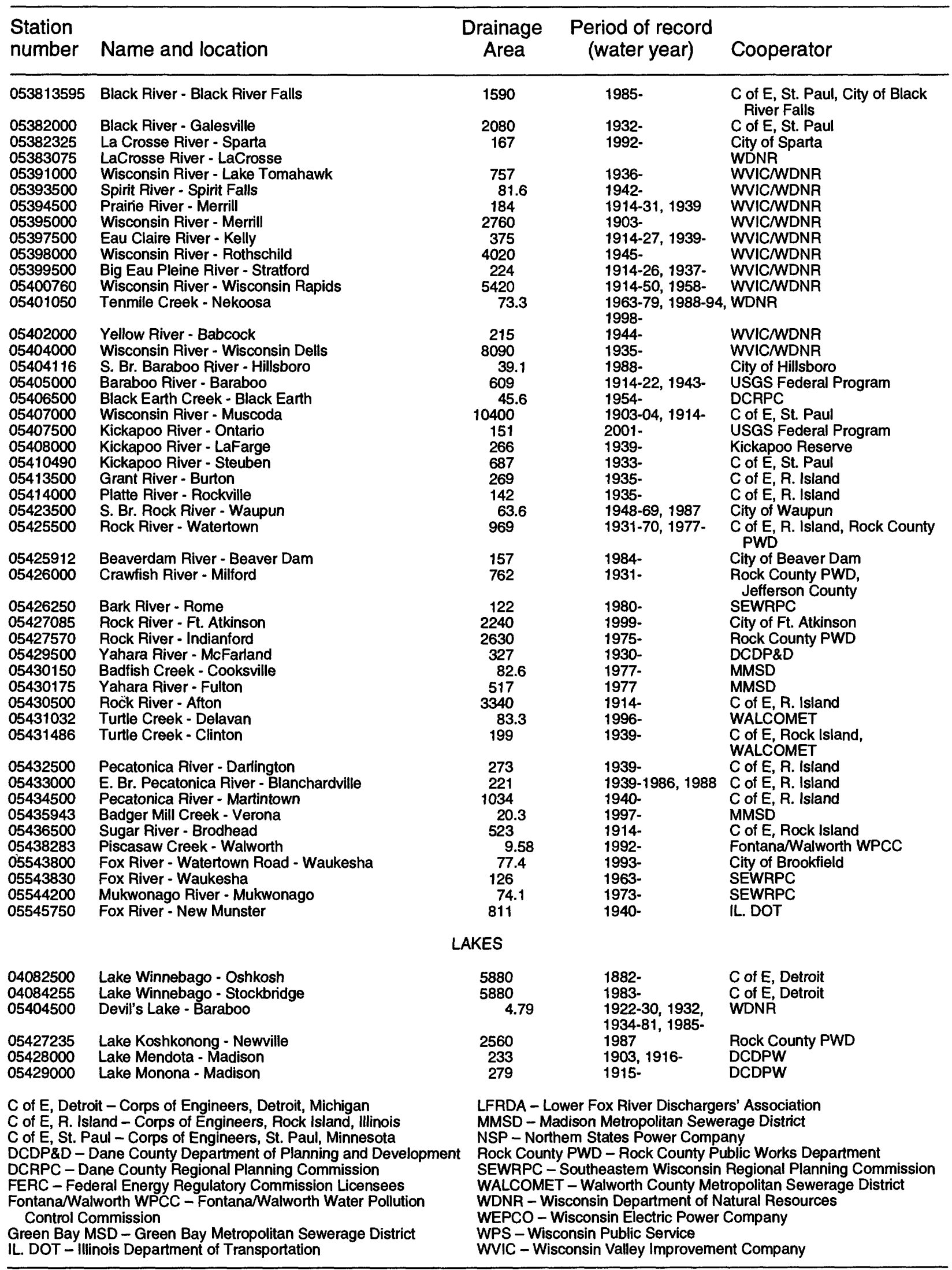




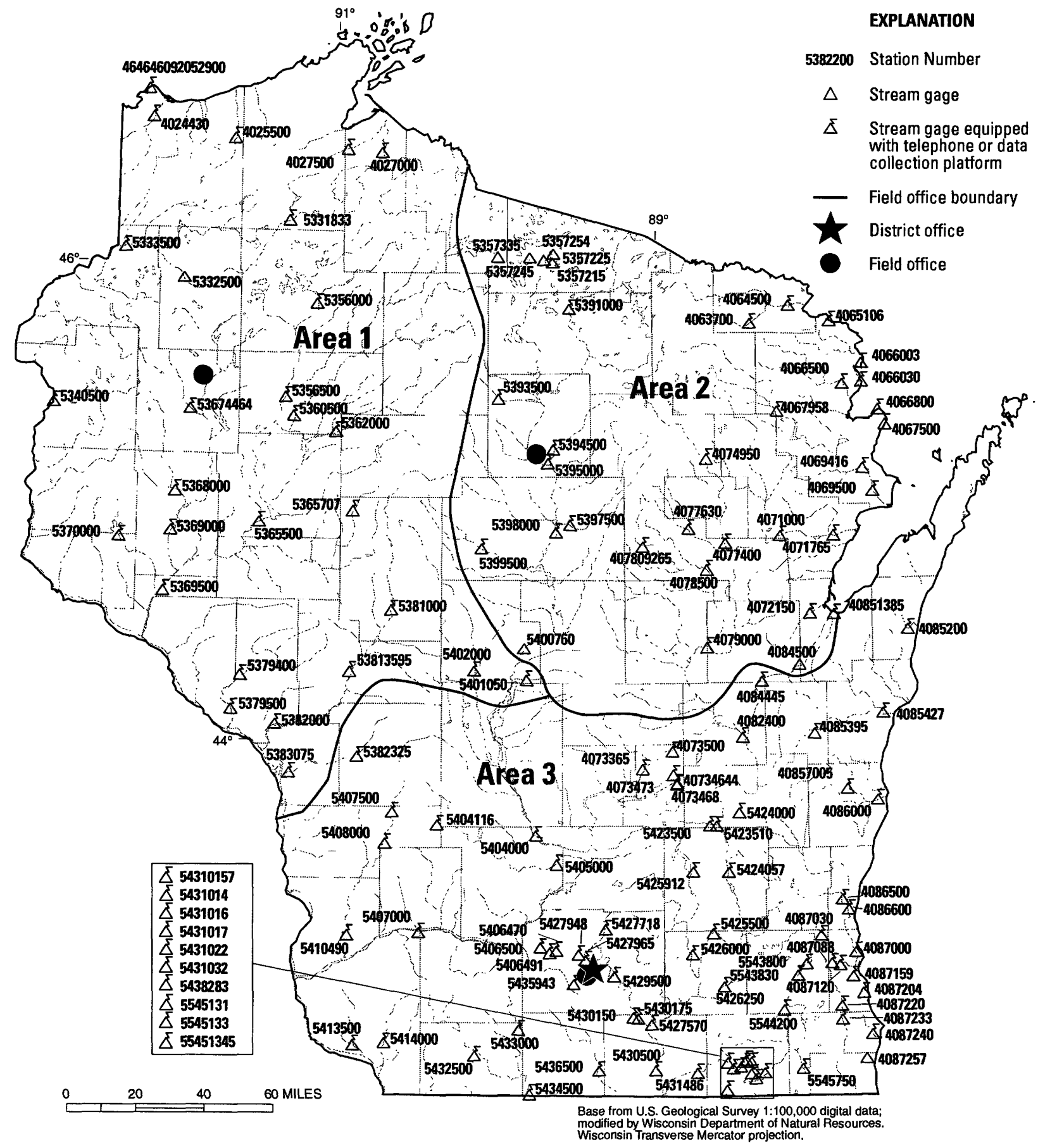

Figure 8. Location of continuous-record data-collection stations. 


\section{DISCONTINUED SURFACE-WATER DISCHARGE STATIONS}

The following continuous-record surface-water discharge stations in Wisconsin have been discontinued. Daily streamflow records were collected and published for the period of record, expressed in water years, shown for each station. Those stations with an asterisk (*) after the station number are currently operated as crest-stage partial-record stations. Some of the discontinued project stations with less than three years of record have not been included. Information regarding these stations may be obtained from the District Office at the address given on the back side of the title page of this report.

\section{Discontinued surface-water discharge stations}

$\begin{array}{lll}\text { Station name } & \begin{array}{l}\text { Station } \\ \text { number }\end{array} & \begin{array}{l}\text { Drainage area } \\ \text { (square miles) }\end{array} \quad \text { Period of record }\end{array}$

STREAMS TRIBUTARY TO LAKE SUPERIOR

Little Balsam Creek at Patzau, WI

Little Balsam Creek near Patzau, WI

Little Balsam Creek Tributary near Patzau, WI

Little Balsam Creek near Foxboro, WI

Amnicon River near Poplar (Amnicon Falls), WI

Bols Brule (Brule) River near Brule, WI

Sioux River near Washbum, WI

Pine Creek at Moquah, WI

Pine Creek Tributary at Moquah, WI

Pine Creek near Moquah, WI

North Fish Creek near Moquah, Wl

Bad River near Mellen, WI

Bad River at Mellen, WI

Alder Creek near Upson, WI

Montreal River near Kimball, WI

West Fork Montreal River at Gile, Wl

West Fork Montreal River near Kimball, WI

$\begin{array}{lc}04024314 & 4.89 \\ 04024315 & 5.05 \\ 04024318 & 0.60 \\ 04024320 & 3.27 \\ 04025000 & 110 \\ 04026000 & 160 \\ 04026300^{\star} & 33.9 \\ 04026347 & 6.20 \\ 04026348 & 0.48 \\ 04026349 & 19.9 \\ 040263491 & 65.4 \\ 04026450^{\star} & 82.0 \\ 04026500 & 98.3 \\ 04026870 & 22.2 \\ 04028500 & 100 \\ 04029000 & 75.0 \\ 04029500 & 86.2\end{array}$

4.89

5.05

3.27

110

33.9

6.20

19.9

65.4

82.0

98.3

100

86.2
1976-78

1976-78

1976-78

1977-78

1914-16

1914-17

1965-66

1976-78

1976-78

1976-78

$1990-91$

$1971-75$

1948-55

1972-77

1924-26

1918-26, 1943-47

1924-26

\section{STREAMS TRIBUTARY TO LAKE MICHIGAN}

North Branch Pine River at Windsor Dam near Alvin, WI

Pine River near Florence, WI

Pine River below Pine River Power Plant near Florence, WI

Peshtigo River at High Falls near Crivitz, Wl

Pensaukee River near Pensaukee, WI

Suamico River at Suamico, WI

Lawrence Creek near Westfield, WI

Grand River near Kingston, WI

West Branch White River near Wautoma, WI

White Creek at Forest Glen Beach near Green Lake, WI

Swamp Creek above Rice Lake at Mole Lake, W

Swamp Creek below Rice Lake at Mole Lake, WI

Wolf River near White Lake, WI

Evergreen Creek near Langlade, WI

Wolf River above West Branch Wolf River, WI

West Branch Wolf River at Neopit, WI

West Branch Wolf River near Keshena, WI

Little Wolf River near Galloway, WI

Spaulding Creek near Big Falls, WI

Little Wolf River at Royalton, WI

Emmons Creek near Rural, WI

Storm Sewer to Mirror Lake at Waupaca, WI

Waupaca River near Waupaca, WI

Daggets Creek at Butte Des Morts, W

West Branch Fond du Lac River at Fond du Lac, WI

East Branch Fond du Lac River near Fond du Lac, WI

Brothertown Creek at Brothertown, WI

East Twin River at Mishicot, WI

Onion River at Hingham, WI

Onion River near Sheboygan Falls, WI

Milwaukee River at Kewaskum, WI

East Branch Milwaukee River near New Fane, WI
$04063640^{*}$

04064000

04064500

04068000

04071858

04072000

04072750

04073050

04073405

04073462

04074538

04074548

04075000

$04075200^{*}$

04075500

04076000

04076500

04079602

$04079700^{*}$

04080000

04080950

04080976

04081000

04081800

04083000

04083500

04084200

04085281

04085813

04085845

04086150

04086200

\section{8}

510

533

537

134

60.7

13.4

73.5

38.9

3.05

46.3

56.8

485

8.09

616

93.2

163

22.6

5.57

507

25.1

0.04

265

10.6

83.1

78.4

5.10

110

37.2

94.1

138

54.1
1967-68

1914-23

1924-76

1912-57

1973-96

1951-52

1968-73

1968-75

1964-75

1982-88

$1977-83,1985-87$

1977-79, 1982-85

1935-38

1964-73

1928-62

1911-17

1928-32

1974-79

1964-66

1914-70, 1983-85

1977

$1971-74$

$1916-66,1983-85$

1977

1939-54

1939-54

1976-77

1972-96

$1979-80$

1979-82

1968-81

1968-81 
Discontinued surface-water discharge stations

\begin{tabular}{llll}
\hline Station name & $\begin{array}{l}\text { Station } \\
\text { number }\end{array}$ & $\begin{array}{l}\text { Drainage area } \\
\text { (square miles) }\end{array} \quad$ Period of record
\end{tabular}

North Branch Milwaukee River near Fillmore, WI $\quad 04086340$

Milwaukee River at Waubeka, WI

Mud Lake Outlet near Decker Comer, WI

Milwaukee River above North Ave. Dam at Milwaukee, WI

Menomonee River at Germantown, WI

Jefferson Park Drainageway at Germantown, WI

Menomonee River at Butler, WI

Little Menomonee River near Freistadt, WI

Noyes Creek at Milwaukee, WI

Little Menomonee River at Milwaukee, WI

Honey Creek at Wauwatosa, WI

Schoonmaker Creek at Wauwatosa, WI

Hawley Road Storm Sewer at Milwaukee, WI

Menomonee River at Milwaukee, WI

Kinnickinnic River at Milwaukee, WI
04086360

04086488

04087010

04087018

04087019

04087040

$04087050^{*}$

04087060

04087070

04087119

04087125

04087130

04087138

04087160
1968-81

1968-81, 1994

1983-84

1975-77

1976-78

1975-79

1975-79

$1975-80,1990$

1975-77

1975-81

1975-79

1975-77

$1982-84$

1976-83

\section{ST. CROIX RIVER BASIN}

Namekagon River at Trego, WI

Loon Creek near Danbury, WI

Bashaw Brook near Shell Lake, WI

Clam River near Webster, WI

St. Croix River near Grantsburg, WI

Wood River near Grantsburg, WI

Rice Creek near Balsam Lake, WI

Balsam Branch at Balsam Lake, WI

Kinnickinnic River near River Falls, WI

05332000
05335010
$05335380^{*}$
05335500
05336000
05339000
05341375
05341402
05342000

CHIPPEWA RIVER BASIN

West Fork Chippewa River at Lessards, near Winter, WI 05355500

Couderay River near Couderay, WI

05356121

Flambeau River at Flambeau Flowage (Flambeau Reservoir), WI05357500

Flambeau River near Butternut, WI

05358000

05358300

Flambeau River at Babbs Island near Winter, WI

05358500

05359500

$05359600^{*}$

05360000

05361000

05361500

05362500

05363000

05363500

05363700

05364000 *

$05364500^{*}$

05364850

05365000

05366000

05366300

05366500

05367000

05367425

05367426

05367500

05369900

05369945

05369955

05369970

05369985

05370500

$$
\begin{gathered}
433 \\
17.6 \\
26.6 \\
361 \\
2,980 \\
185 \\
12.5 \\
52.8 \\
165
\end{gathered}
$$

1914-27

1970-71

1964-66

1941-42

1923-70

1939-40

1988-89

1988-90

1917-21
1912-16

1981-83

1927-61

1914-39

1971-75

1929-75

1929-75

1964-66

1903-06, 1914-61

1944-49

1944-54

1943-49

1944-45

1944-45

1962-63

1943-61

1944-52

1987-89

1943-55

1914-26

1980

1943-55

1903-09, 1944-54

1966-70

1971-73

1914-80, 1989-90

1978-83

1982-83, 1986-96

1981-83

1981-83

1981-83

1943-54

\section{BUFFALO RIVER BASIN}




\section{Discontinued surface-water discharge stations}

\begin{tabular}{llll}
\hline Station name & $\begin{array}{l}\text { Station } \\
\text { number }\end{array}$ & $\begin{array}{l}\text { Drainage area } \\
\text { (square miles) }\end{array} \quad$ Period of record
\end{tabular}

TREMPEALEAU RIVER BASIN

Bruce Valley Creek near Pleasantville, WI Elk Creek near Independence, WI

Trempealeau River near Trempealeau, WI

Black River at Medford, WI

Poplar River near Owen, WI

Little LaCrosse River near Leon, WI

LaCrosse River near West Salem, WI

Spring Coulee Creek near Coon Valley, WI

Coon Creek at Coon Valley, WI

Coon Creek near Stoddard, WI

North Fork Bad Axe River near Genoa, WI
05379288

05379305

05380000

BLACK RIVER BASIN

05380806

05380900*

\section{LA CROSSE RIVER BASIN}

05382500

05383000

76.9

396

\section{COON CREEK BASIN}

05386490

05386500

05386999

9.01
77.2

120

\section{BAD AXE RIVER BASIN}

$05387100^{*}$

80.8

1964-66

10.1

719

1980

1932-34

1984-87

1964-66

$1914-70$

1979-81

\section{WISCONSIN RIVER BASIN}

Wisconsin River at Conover, WI

Pelican River near Rhinelander, WI

Wisconsin River at Whirlpool Rapids, near Rhinelander, WI

Bearskin Creek near Harshaw, WI

Tomahawk River near Bradley, W

Tomahawk River at Bradley, WI

New Wood River near Merrill, WI

Rib River at Rib Falls, WI

Little Rib River near Wausau, W!

East Branch Eau Claire River near Antigo, WI

Eau Claire River near Antigo, WI

Bull Junior Creek (Bull Creek Junior) near Rothschild, WI

Big Eau Pleine River near Colby, Wi

Hamann Creek near Stratford, WI

Wisconsin River at Knowlton, W

Plover River near Stevens Point, WI

Little Plover River near Arnott, WI

Little Plover River at Plover, WI

Fourmile Creek near Kellner, $W I$

Buena Vista Creek near Kellner, WI

Tenmile Creek Ditch 5 near Bancroft, WI

Fourteenmile Creek near New Rome, WI

Wisconsin River near Necedah, WI

Big Roche a Cri Creek near Hancock, W

Big Roche a Cri Creek near Adams, WI

Yellow River at Sprague, WI

Yellow River at Necedah, Wl

Lemonweir River at New Lisbon, WI

Hulbert Creek near Wisconsin Dells, WI

Dell Creek near Lake Delton, Wl

Narrows Creek at Loganville, WI

Wisconsin River at Prairie du Sac, WI

Trout Creek at Confluence with Ameson Creek near Bameveld,

Trout Creek at Twin Parks Dam 8 near Bameveld, WI

Trout Creek at County Highway T near Bameveld, WI

Trout Creek near Ridgeway, WI

Knight Hollow Creek near Arena, WI

Otter Creek near Highland, WI

Knapp Creek near Bloomingdale, WI

West Fork Kickapoo River near Readstown, WI

Kickapoo River at Soldiers Grove, WI
05390180

05391226

05392000

$05392350^{*}$

05392400

05393000

05394000

05396000

05396500

05397000

05397110

05398500

05399000

05399431

05400000

05400500

05400600

05400650

05400840

05400853

05401020

05401100

05401500

05401510

05401535

05402500

05403000

05403500

$05403630^{*}$

$05403700^{*}$

$05404200^{*}$

05406000

WI 05406573

05406574

05406575

05406577

05406590

05406640

05408500

05409000

05409500
1934-61, 1979-81

1934-40, 1978-81

$1934-40,1979-81$

1967-71

1976-79

1906-61

1964-66

1915-27, 1929

1930-73

1953-61

1925-57

1914-16

1949-55

1975-81

1944-52

1941-54

1977-79

1921-42

1914-20, 1944-52

1959-75

1959-87

1964-67

1964-67

1964-73

1964-79

1903-14, 1944-50

1964-67

1964-78

1927-40

1941-57

1944-87, 1994

1971-77

$1957-65,1971-80$

1964-66

1946-54

1976-79

1976-78

1976-79

1976-78

$1968-69,1970-75$

1955-69

1939

1939 
Discontinued surface-water discharge stations

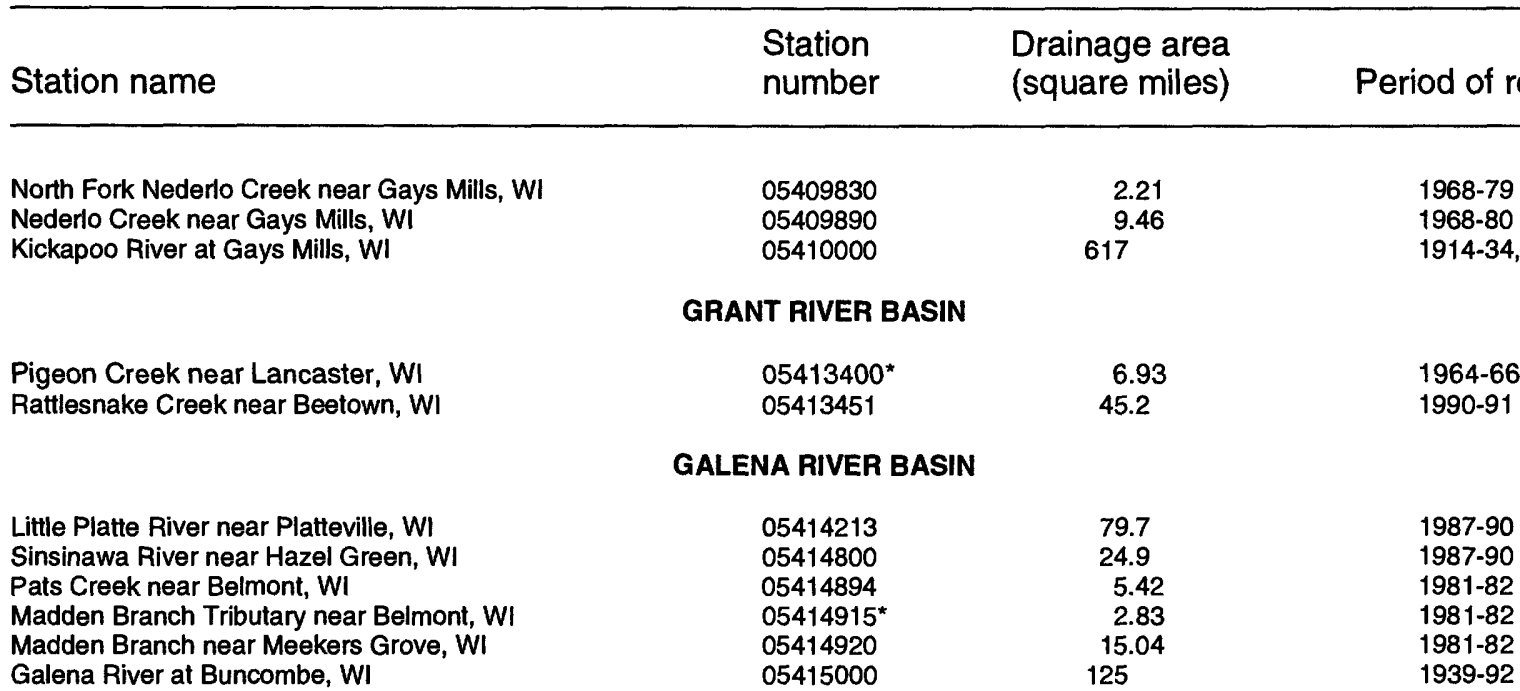

\section{APPLE RIVER BASIN}

Apple River near Shullsburg, WI

West Branch Rock River near Waupun, WI

West Branch Rock River at County Trunk Highway D near Waupun, WI

East Branch Rock River near Mayville, WI

Rock River at Hustisford, WI

Johnson Creek near Johnson Creek, WI

Johnson Creek near Johnson Creek, WI

Pratt Creek near Juneau, WI

Rock River at Jefferson, WI

Whitewater Creek near Whitewater, WI

Whitewater Creek at Millis Road near Whitewater, WI

Whitewater Creek at Whitewater, W!

Koshkonong Creek near Rockdale, WI

Token Creek near Madison, WI

Sixmile Creek near Waunakee, WI

Pheasant Branch at Airport Road near Middleton, WI

South Fork Pheasant Branch at Highway 14 near Midd

Pheasant Branch at Century Avenue at Middleton, WI

Pheasant Branch at mouth at Middleton, WI

Willow Creek at Madison, WI

Olbrich Park Storm Ditch at Madison, WI

Manitou Way Storm Sewer at Madison, WI

Nakoma Storm Sewer at Madison, WI

Lake Wingra Outlet at Madison, WI

Door Creek near Cottage Grove, WI

Yahara River near Edgerton, WI

Oregon Branch at Oregon, WI

Badfish Creek at County Highway A near Stoughton, WI

Badfish Creek near Stoughton, $W$

Jackson Creek at Petrie Road near Elkhorn, WI

Livingston Branch, Pecatonica River near Livingston, WI

Yellowstone River near Blanchardville, WI

Pecatonica River at Dill, WI

Steiner Branch near Waldwick, WI

Skinner Creek at Skinner Hollow Road near Monroe, WI

Skinner Creek at Klondyke Road near Monroe, WI

West Branch Sugar River near Mount Vernon, WI

Mount Vernon Creek near Mount Vernon, WI
05418731

$1981-82$

\section{ROCK RIVER BASIN}

$\begin{array}{lcl}05423000 & 40.7 & 1949-70,1978-81 \\ 05423100 & 43.9 & 1978-81 \\ 05424000 & 179 & 1949-70 \\ 05424082 & 511 & 1978-85 \\ 05425537 & 1.13 & 1978-80 \\ 05425539 & 13.3 & 1978-80 \\ 05425928 & 3.54 & 1978-80 \\ 05426031 & 1,850 & 1978-94 \\ 05426500 & 11.8 & 1926-28,1946-54 \\ 05426900 & 20.6 & 1978-81 \\ 05427000 & 22.8 & 1926-28,1946-54 \\ 05427507 & 150 & 1977-82 \\ 05427800^{*} & 24.3 & 1964-66,1976-81 \\ 05427900 & 41.1 & 1976-82 \\ 05427943 & 9.61 & 1977-81 \\ 05427945 & 5.74 & 1978-81 \\ 05427950 & 20.8 & 1977-81 \\ 05427952 & 24.5 & 1978-81 \\ 05427970 & 3.15 & 1974-83 \\ 05428665 & 2.57 & 1976-80 \\ 05429040 & 0.23 & 1971-77 \\ 05429050 & 2.30 & 1972-77 \\ 05429120 & 6.00 & 1971-77 \\ 05429580 & 15.3 & 1976-79 \\ 05430000 & 430 & 1917-18 \\ 05430030 & 9.93 & 1979-81 \\ 05430095 & 41.9 & 1956-66,1986-88 \\ 05430100 & 41.3 & 1956-66 \\ 05431014 & 8.96 & 1984-95 \\ 05432055 & 16.4 & 1987-91 \\ 05433500^{*} & 28.5 & 1954-65,1978-79 \\ 05434000 & 944 & 1914-19 \\ 05433510 & 5.9 & 1978-79 \\ 05434235 & 32.6 & 1978-81 \\ 05434240 & 35.0 & 1978-81 \\ 05435980 & 32.7 & 1979-80 \\ 05436000 & 16.4 & 1954-65,1976-80\end{array}$

\section{ILLINOIS RIVER BASIN}




\section{COLLECTION OF BASIC RECORDS-GROUND WATER, WI 00200}

\section{COOPERATOR:}

Wisconsin Geological and Natural History Survey

\section{LOCATION:}

Statewide

\section{PROJECT CHIEF:}

Bernard R. Ellefson

PERIOD OF PROJECT: July 1946-Continuing
PROBLEM: Ground-water data are needed to determine shortterm changes and long-term trends in ground-water levels in the State. It is important to know if these changes are natural or maninduced and how these changes are affecting storage in the groundwater reservoirs.

OBJECTIVE: The objective is to maintain records of groundwater levels from a network of observation wells representative of Wisconsin's principal aquifers.

APPROACH: A basic network of about 135 wells is being maintained. The network will be constantly modified and improved to provide the best possible coverage of our ground-water resource. A subnetwork of key wells is included in this network. Key wells have long periods of record and are measured weekly or are equipped with continuous recorders.

PROGRESS (July 1999 to June 2000): Slug testing and geophysical logging were completed on four additional wells in a continuing effort to evaluate the network. Water-level data for the annual report, "Water Resources Data-Wisconsin, water year 1999", was completed. Four wells were drilled to replace ones that were plugged. Ground-water levels for selected wells are available on the internet at http://wi.water.usgs.gov.

PLANS (July 2000 to June 2001): Plans include: (1) continue measurements on observation-well network, (2) replace and hire new observers and make quality-assurance checks when possible, (3) data evaluation and preparation for the annual report, and (4) drill and install equipment for six new wells to replace wells that were found to be plugged during testing.

\section{REPORTS:}

Patterson, G.L., and Zaporozec, A., 1988, Analysis of water-level fluctuations in Wisconsin wells: Wisconsin Geological and Natural History Survey Information Circular 63.

Erickson, R.M., and Cotter, R.D., 1983, Trends in ground-water levels in Wisconsin through 1981: Wisconsin Geological and Natural History Survey Information Circular No. 43.

Erickson, R.M., 1972, Trends in ground-water levels in Wisconsin, 1967-71: Wisconsin Geological and Natural History Survey Information Circular No. 21.

Devaul, R.W., 1967, Trends in ground-water levels in Wisconsin through 1966: Wisconsin Geological and Natural History Survey Information Circular No. 9. 


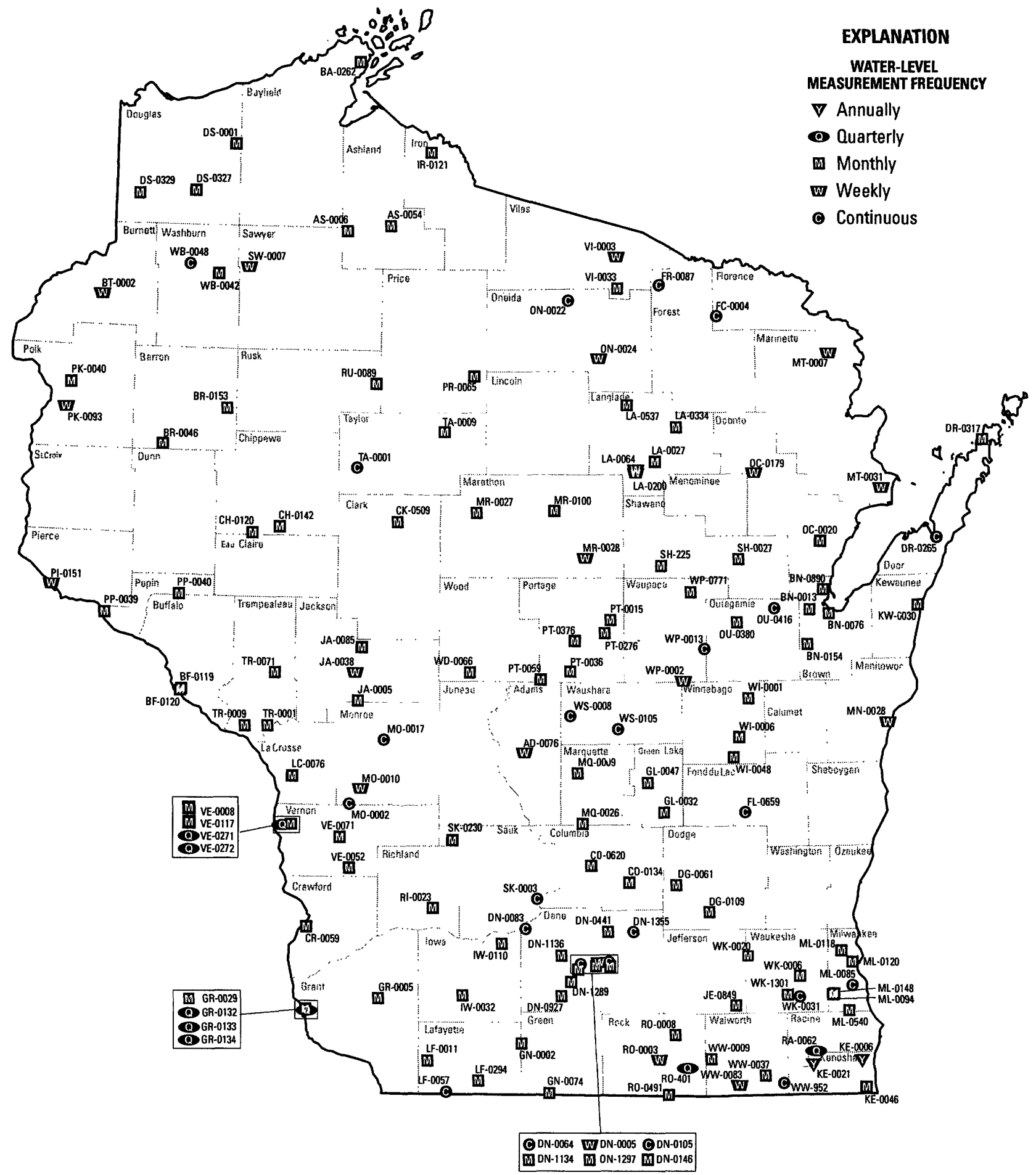

Figure 9. Location of network observation wells. 


\section{CRANDON GROUND WATER, WI 00201}

COOPERATOR:

Wisconsin Department of Natural Resources

\section{LOCATION:}

Forest County

\section{PROJECT CHIEF: \\ James T. Krohelski}

\section{PERIOD OF PROJECT: October 1994-Continuing}

PROBLEM: A large underground zinc-copper mine is being proposed at a site about five miles south of Crandon, Wisconsin, in Forest County. The Wisconsin Department of Natural Resources (WDNR) requested that District staff review the development of a ground-water-flow model and associated hydrologic documents as part of a permitting process for the proposed mine.

OBJECTIVE: The objective is to review documents related to water resources submitted to WDNR from the Nicolet Mining Company and their consultants and to make suggestions to WDNR on studies and approaches that will improve the understanding of the hydrology and effects of mining on the water resources in the vicinity of the proposed mine.

APPROACH: The schedule for review of documents will be mutually agreed upon between WDNR and USGS.

PROGRESS (July 1999 to June 2000): Ground-water-flow model calibration and predictive simulations, based on the calibrated ground-water model, were completed. Monitoring of lake stage and shallow ground-water levels adjacent to Little Sand Lake and Skunk Lake was continued.

PLANS (July 2000 to June 2001): Documents will be reviewed and meetings attended at the request of the WDNR. Descriptions of model development, calibration and simulation results of the flow model will be summarized and submitted to the Wisconsin Department of Natural Resources. Monitoring of lake stage and shallow ground-water levels adjacent to Little Sand Lake will be continued.

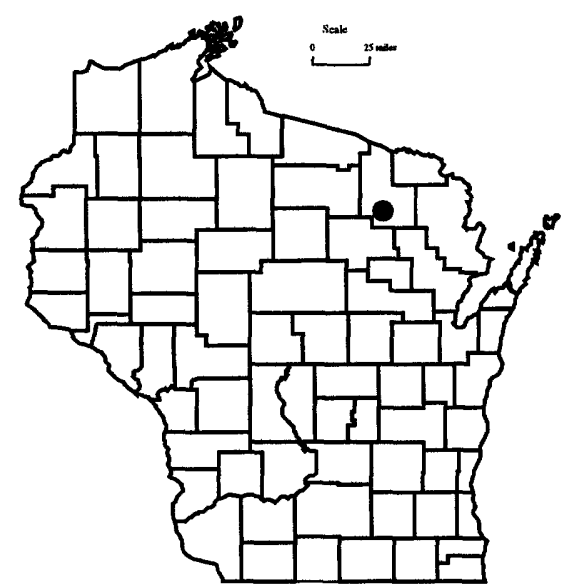




\section{COLLECTION OF BASIC RECORDS-DANE COUNTY PROGRAM, WI 00302}

PROBLEM: A long-term base of water-quality data is needed for water-resource planning and assessment of water quality in the lakes and streams of Dane County.

OBJECTIVE: The objectives of this program are to determine suspended-sediment and phosphorus loads of selected tributaries to Lake Mendota and to collect data to identify long-term changes in base-flow water quality in selected streams in Dane County.

APPROACH: Streamflow-monitoring stations with automatic water-quality samplers are operated on three tributaries to Lake Mendota. Samples for analysis of suspended-sediment and phosphorus concentrations are collected at low flow and during periods when surface runoff is entering the streams. The concentration and streamflow data are used to compute annual suspended-sediment and total-phosphorus loads for the three stations. Various water-quality constituents are measured six times during the year at base flow of selected streams in the county.

PROGRESS (July 1999 to June 2000): On-going streamflow and water-quality data collection at three continuousrecord monitoring sites (Pheasant Branch at Middleton, Spring Harbor Storm Sewer at Madison, and Yahara River at Windsor) continued. Suspended-sediment loads were computed for Spring Harbor Storm Sewer, and suspended-sediment and total-phosphorus loads were computed for the Yahara River and Pheasant Branch for the 1999 water year. Continuous-streamflow monitoring at Black Earth Creek near Black Earth was continued for the year.

Base-flow water-quality sampling was completed for Black Earth Creek near Cross Plains, West Branch Sugar River near Mt. Vernon, Koshkonong Creek near Sun Prairie, and Koshkonong Creek near Rockdale in December 1999. Base-flow sampling was begun at a new set of four streams in the county for 2000. All streamflow, load and concentration data were published in the annual data report "Water Resources Data-Wisconsin".

PLANS (July 2000 to June 2001): Streamflow monitoring will be continued at Black Earth Creek; streamflow and waterquality monitoring will be continued at the three continuous-record sites on tributaries to Lake Mendota. Six base-flow water-quality samples will be collected from Mt. Vernon Creek near Mt. Vernon, Six Mile Creek near Waunakee, Door Creek near Cottage Grove, and Yahara River near Stoughton during the calendar year (starting in spring 2000). Records and loads will be computed. Final data will be prepared and published in the annual data report, "Water Resources Data-Wisconsin".
COOPERATOR:

Dane County Regional Planning Commission

LOCATION:

Dane County

PROJECT CHIEF:

Herbert S. Garn

PERIOD OF PROJECT:

Continuing

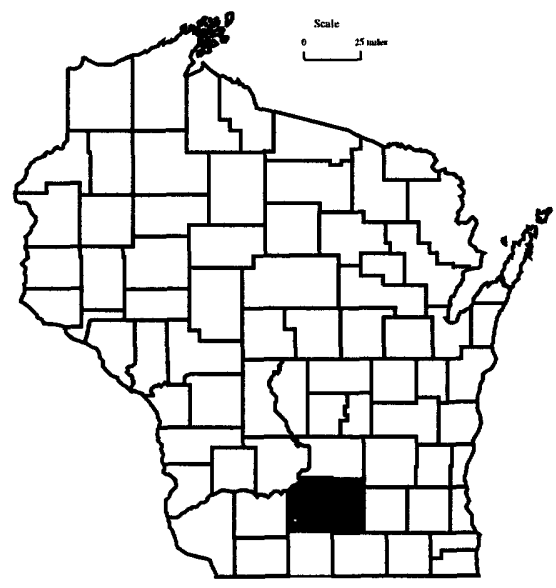




\section{INTERAGENCY METHODS AND DATA COMPARABILITY BOARD (MDCB), WI 00303}

COOPERATOR:

U.S. Geological Survey

LOCATION:

Comprised of individuals from throughout the United States

PROJECT CHIEF:

Charles A. Peters

PERIOD OF PROJECT:

April 1998 to April 2001
PROBLEM: Significant resources are spent to monitor water quality in the United States. The methods used to collect water samples and to analyze the samples collected vary between the collecting authority. The data obtained using the various methods may not be comparable and therefore each monitoring entity may collect duplicate data.

OBJECTIVE: A nationwide partnership of water-monitoring authorities from Federal and State agencies, tribes, municipalities, business and industry, academia, and others with expertise in environmental monitoring has been assembled to coordinate and provide guidance for implementation of a voluntary, integrated, nationwide monitoring strategy that will provide comparable data.

APPROACH: The MDCB holds quarterly meetings to discuss the progress and plans of work groups formed to develop consensus positions regarding issues related to sampling and analytical approaches. The seven work groups (Performance Based Systems, National Environmental Methods Index, Laboratory Accreditation and Field Certification, Biological Methods, Nutrient Methods, Water Quality Data Elements, and Publicity and Outreach) establish work plans and meet via conference calls and at the quarterly MDCB meetings to accomplish work plan objectives.

PROGRESS (July 1999 to June 2000): A co-chair is responsible for maintaining a public website, developing work plans, organizing meetings and conference calls, preparing meeting minutes, assisting with the preparation of position papers and pilot studies, preparing outreach products, and providing guidance for and participating in other MDCB activities. The co-chair also participates as a member of the National Water Quality Monitoring Council (NWQMC) and as a member of the NWQMC steering committee.

PLANS (July 2000 to April 2001): The co-chair will continue to maintain a public website, develop work plans, organize meetings and conference calls, prepare meeting minutes, assist with the preparation of position papers and pilot studies, prepare outreach products, and provide guidance for and participate in other MDCB activities. 


\section{AGE DATING GROUND WATER IN ATRAZINE PROHIBITION AREAS IN WISCONSIN, WI 00304}

PROBLEM: The Wisconsin Department of Agriculture, Trade and Consumer Protection (DATCP) will be monitoring groundwater quality from 63 wells at 21 locations in Wisconsin to determine if atrazine can be safely reintroduced in atrazine prohibition areas. The wells will be monitored for a five- or six-year period in order to detect changes in atrazine concentrations in ground water. It will be necessary to determine the age of the sampled ground water to show that the five- or six-year sampling period is long enough to show the effects of atrazine reuse on shallow ground-water quality.

OBJECTIVE: The objective of this project is to determine the age of the ground water that will be sampled in the atrazine reuse areas. The data collected for this study will be used to determine whether the planned five- or six-year monitoring period is sufficient to show the effects of atrazine reuse on shallow ground-water quality.

APPROACH: The U.S. Geological Survey (USGS), Wisconsin District will use chlorofluorocarbons (CFCs) to determine the age of shallow ground water from one well at each of the 21 locations chosen by DATCP. CFC samples will be collected, analyzed, and ground-water ages determined using procedures and equipment developed by the USGS.

PROGRESS (July 1999 to June 2000): None.

PLANS (July 2000 to September 2000): Additional monitor wells, to be sampled as part of this study, will be installed by DATCP during summer 2000. Fifteen CFC and five dissolved gas samples will be collected and sent for analysis.
COOPERATOR:

Wisconsin Department of

Agriculture, Trade and Consumer Protection

\section{LOCATION:}

Statewide

PROJECT CHIEF:

David A. Saad

PERIOD OF PROJECT:

June 1998 to September 2000

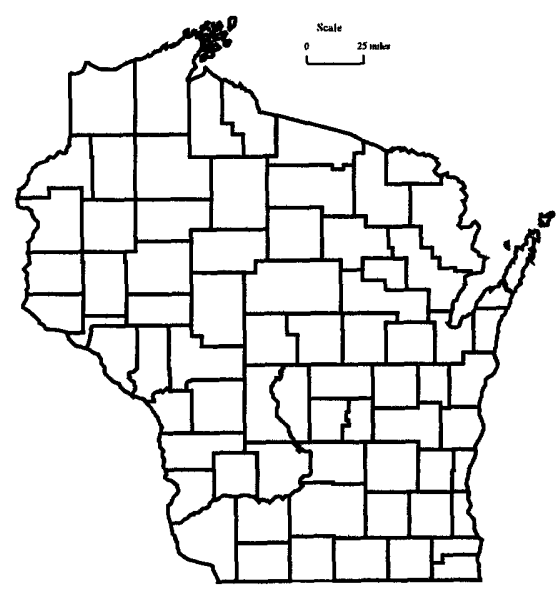




\section{GROUND-WATER AGE DATING IN THE LITTLE PLOVER RIVER BASIN, WISCONSIN, WI 00351}

\author{
COOPERATOR: \\ University of Wisconsin-Stevens \\ Point
}

\section{LOCATION: \\ Wood County}

\author{
PROJECT CHIEF: \\ David A. Saad
}

PERIOD OF PROJECT: July 1997 to September 2000
PROBLEM: The Little Plover River Basin is in one of the most highly productive irrigated agricultural regions of the Midwest United States. It has been the focus of studies relating to land use, hydrology, and water quality for over 30 years. The UW-Stevens Point, College of Natural Resources, is trying to develop a way of using data from the ground-water/surface-water interface in the basin to obtain a synoptic historical view of land-use and water-quality relations at the watershed scale. Determination of ground-water ages at the ground-water/surface-water interface would provide useful information for understanding ground-water flow in the basin and for linking water quality with historic land uses.

OBJECTIVE: The objective of this study is to estimate age of ground water at the ground-water/surface-water interface at approximately 100 locations in the basin.

APPROACH: Ground-water ages will be estimated using chlorofluorocarbons (CFCs). CFCs will be collected from existing nearand in-stream networks of minipiezometers. CFC samples will be collected and analyzed using procedures and equipment developed by the USGS.

PROGRESS (July 1999 to June 2000): None.

PLANS (July 2000 to September 2000): Forty CFC samples and two dissolved gas samples will be collected during summer 2000. Interpretation of CFC and dissolved gas sample data may be included in a future journal article.

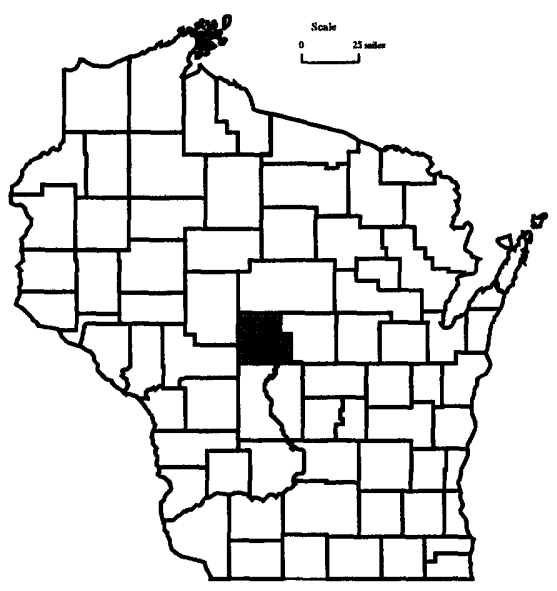




\section{COLLECTION OF BASIC RECORDS-SEDIMENT, WI 00400}

PROBLEM: Water-resources planning and water-quality assessment require a knowledge of the quantity and quality of sediment being transported in rivers and streams in Wisconsin.

OBJECTIVE: This project will provide sediment data for use in specific planning and action programs and will develop a database for determining trends in sediment discharge and yield. Streams will be characterized according to range of concentration and particle size of suspended sediment.

APPROACH: Sediment-monitoring stations will be operated at selected stream sites throughout the State, including sites of specific interest to cooperating agencies.

The extent of monitoring at a given site will depend on the characteristics of the basin and the needs of the cooperating agency. Some sites will be sampled manually at infrequent intervals; other sites, where flow responds rapidly to precipitation, will be sampled by automatic samplers.

At sites where bedload or unmeasured sediment discharge may be a significant part of the total sediment discharge, suspended- and bedsediment particle size will be determined from samples collected concurrently with hydraulic data. These data will be used to estimate total sediment discharge using one of several techniques such as the modified Einstein procedure.

PROGRESS (July 1999 to June 2000): Sediment data have been collected at more than 200 stream sites in Wisconsin since 1968. All data have been published annually in the data report, "Water Resources Data-Wisconsin". The 2000 monitoring program is as follows:

CORPS OF ENGINEERS-Suspended sediment was sampled at the Grant River at Burton. Equipment was upgraded to include an automatic water sampler to improve sampling coverage during storm events. Daily loads were determined from these data.

PLANS (July 2000 to June 2001):

CORPS OF ENGINEERS-Operation of the Grant River monitoring station will continue.

Efforts to secure cooperative funding to establish a long-term sediment-monitoring network will continue. About 10 sites areally distributed to sample runoff from the major geographic provinces would provide an adequate network.

\section{REPORTS:}

Rose, William J., and Graczyk, David J., 1996, Sediment transport, particle size, and loads in North Fish Creek in Bayfield County, Wisconsin, water years 1990-91, U.S. Geological Survey Water-Resources Investigations Report 95-4222, 18 p.

Rose, William J., 1992, Sediment transport, particle sizes, and loads in the lower reaches of the Chippewa, Black, and Wisconsin Rivers in western Wisconsin, U.S. Geological Survey WaterResources Investigations Report 90-4124, 38 p.
COOPERATORS:

U.S. Army Corps of Engineers

LOCATION:

Statewide

PROJECT CHIEF:

William J. Rose

PERIOD OF PROJECT:

March 1968-Continuing

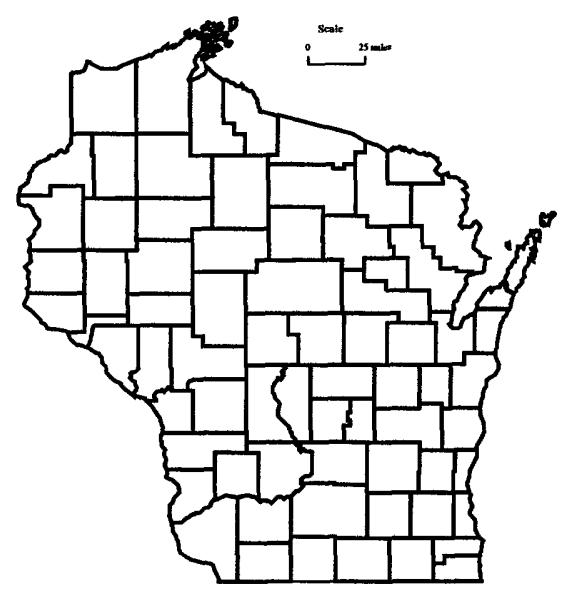




\section{MENOMONEE RIVER CHANNEL RESTORATION, WI00404}

\author{
COOPERATORS: \\ Wisconsin Department of \\ Transportation
}

\section{LOCATION:}

Milwaukee

\section{PROJECT CHIEF: Faith Fitzpatrick}

PERIOD OF PROJECT: April 2000 to June 2000
PROBLEM: The Highway 45 bridge over the Menomonee River near Wauwatosa, Wisconsin, will be replaced in the spring of 2000. A series of pilings supporting the existing bridge caused destabilization of the Menomonee River channel. The pilings will be replaced with a single pier for the new bridge design. The channel in the bridge zone needs to be restored to a stable design.

OBJECTIVE: Objective one is to measure existing channel dimensions, planform, and gradient within the bridge zone and in reference reaches upstream and downstream of the bridge. The reference reaches will be used as a template for the width, depth, gradient, and planform characteristics of the design channel in the bridge zone. Objective two is to provide the Wisconsin Department of Transportation with stable channel dimensions, planform, and gradient for the design channel in the bridge zone.

APPROACH: Existing channel dimensions and interconnectivity of flood-plain will be measured. Channel and flood-plain crosssection surveys of reference upstream and downstream reaches and bridge zone will be conducted. Channel and flood-plain gradient upstream, downstream, and through reach will be measured. Sediment characteristics in flood-plain stream banks, and channel in reference reaches through exploratory coring and textural analyses will be determined. Existing flood characteristics - using USGS gaging station data from Menomonee Falls (34.7 $\mathrm{mi}^{2} ; 0408730 ; 1974$-present) and Wauwatosa $\left(123 \mathrm{mi}^{2} ; 04087120 ; 1961\right.$-present $)$ weighted for drainage area at Hwy 45 (about $61 \mathrm{mi}^{2}$ ) will be evaluated. Design discharge for restored channel using bankfull discharges estimated from upstream and downstream reaches will be determined. Flood discharges through upstream and downstream reaches as well as bridge zone using HEC-RAS or WSPRO will be estimated.

PROGRESS: Project to be completed by June 2000.

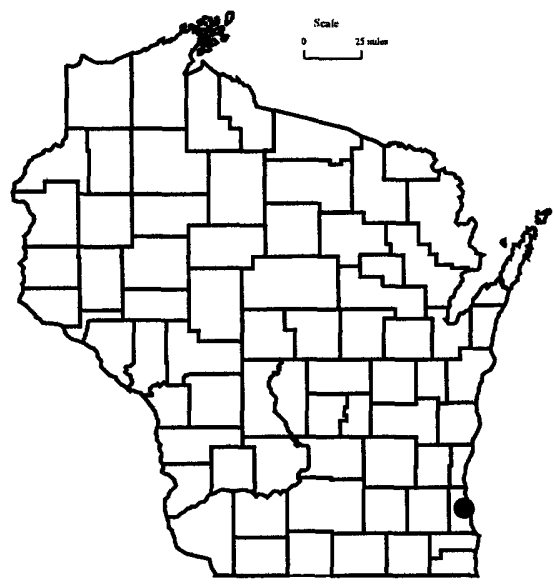




\section{WISCONSIN WATER-USE DATA FILE, WI 00700}

PROBLEM: The need for reliable water-use data by State and Federal planning agencies is increasing as the competition for use of the State's water resources increases. Water-use data in a standardized format needs to be available to assist in making decisions on future water use.

OBJECTIVE: The purpose of this project is to collect accurate and complete data on Wisconsin's water use, store data in the State Water-Use Data System (SWUDS), and prepare periodic reports on water use in the State.

APPROACH: Sources of water-use information will be evaluated. The best available data will be entered into SWUDS. Efforts will be made to upgrade the accuracy of the water-use data.

PROGRESS (July 1999 to June 2000): SWUDS was updated with current water-use information. These data included high-capacity well data and information on discharge from sewagetreatment plants in the State. Reformatting programs were written or updated as needed for entering data from other agencies into SWUDS.

PLANS (July 2000 to June 2001): Plans include: (1) continue to update and maintain SWUDS with current water-use data, (2) supply water-use data for water-resources studies currently being conducted in the State and (3) work with Department of Natural Resources and Wisconsin Geological and Natural History Survey in a joint effort to establish a water-use database that can be used and updated by each agency.

\section{REPORTS:}

Ellefson, B.R., Fan, C.H., and Ripley, J.L., 1995, Water use in Wisconsin, 1995: U.S. Geological Survey Open-File Report 97-356, 1 sheet, scale 1:5,000,000.

Ellefson, B.R., Sabin, T.J., Krohelski, J.T., 1993, Water use in Wisconsin, 1990: U.S. Geological Survey Open-File Report 93118,1 sheet, scale $1: 5,000,000$.

Ellefson, B.R., Rury, K.S., and Krohelski, J.T., 1988, Water-use in Wisconsin, 1985: U.S. Geological Survey Open-File Report 87-699, 1 sheet, scale 1:5,000,000.

U.S. Geological Survey, 1990, National Water Summary, 1987Hydrologic events and water supply and use: U.S. Geological Survey Water-Supply Paper 2350, $553 \mathrm{p}$.

Krohelski, J.T., Ellefson, B.R., and Storlie, C.A., 1987, Estimated use of ground water for irrigation in Wisconsin, 1984: U.S. Geological Survey Water-Resources Investigations Report 86-4079, 12 p., 1 pl.

Lawrence, C.L., and Ellefson, B.R., 1984, Public-supply pumpage in Wisconsin, by aquifer: U.S. Geological Survey Open-File Report 83-931, $40 \mathrm{p}$.

,1982, Water use in Wisconsin, 1979: U.S. Geological Survey Open-File Report 82-444, 98 p.
COOPERATOR:

Wisconsin Department of

Natural Resources

LOCATION:

Statewide

PROJECT CHIEF:

Bernard R. Ellefson

PERIOD OF PROJECT:

March 1978-Continuing

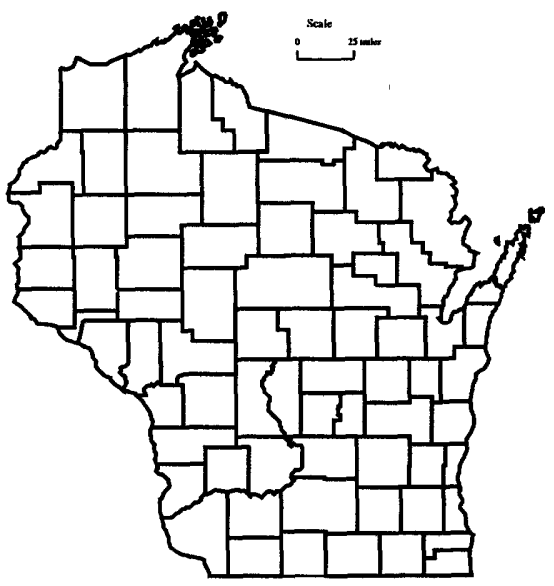




\section{REGIONAL FLOOD-FREQUENCY STUDY FOR URBAN AND RURAL STREAMS IN WISCONSIN, WI 10900}

COOPERATOR:

City of Fond du Lac

Wisconsin Department of

Transportation

\section{LOCATION:}

Statewide

PROJECT CHIEF:

William R. Krug

PERIOD OF PROJECT:

July 1985 -Continuing

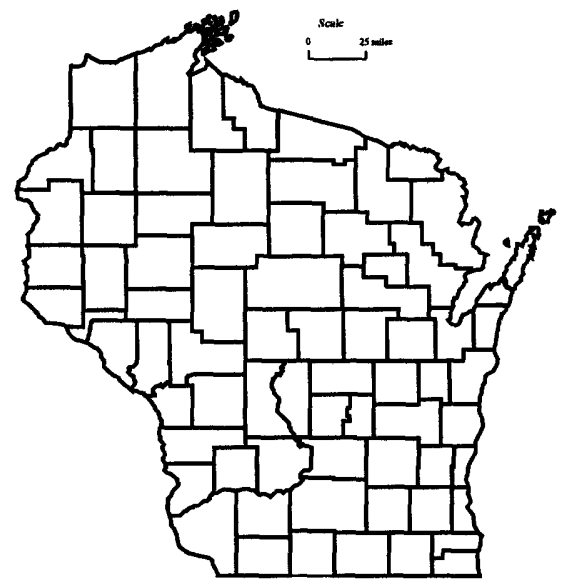

PROBLEM: Flood-frequency estimates are required at many sites for bridge and culvert design, as well as for flood-plain management and flood-insurance studies. Most sites at which such estimates are required do not have records of flood peaks.

OBJECTIVE: Objectives are to (1) operate a State-wide network of crest gages to obtain ongoing information on flood peaks; (2) develop improved regression equations for the State of Wisconsin; and (3) analyze and improve the network of crest-stage gages to obtain better data for developing improved regression equations.

APPROACH: A network of approximately 100 crest-stage gages will be maintained to gather flood peak information, especially on streams with small drainage areas. The information on annual flood peaks will be used to compute flood-frequency at these sites. Periodically, the expanded information on flood frequency at streams throughout the state will be used to compute regional floodfrequency equations to estimate flood frequency at ungaged sites.

PROGRESS (July 1999 to June 2000): Annual flood peaks were computed and published in the annual data report for 79 creststage stations, including 13 new stations. New stations have been installed in areas where the cooperator indicated the greatest need for more information on flooding. Significant effort has been made in measuring flood discharges at crest gages, especially at the newly installed gages, and improving ratings at crest gages. Flood frequency has been recalculated using data through water year 1998.

PLANS (July 2000 to June 2001): The crest-stage-gage network will be monitored throughout the year. Ratings will be developed for more new gages as measurements and surveys are available. Significant effort will be made to improve ratings at all the gages. Work will begin on recalculating regression equations for computing flood frequency.

\section{REPORTS:}

Krug, W.R., 1996, Simulation of temporal changes in rainfall-runoff characteristics, Coon Creek Basin, Wisconsin: Journal of the American Water Resources Association, v. 32, no. 4, p. 745752.

Krug, W.R., Conger, D.H., and Gebert, W.A., 1992, Floodfrequency characteristics of Wisconsin streams: U.S. Geological Survey Water-Resources Investigations Report 91-4128, 185 p., 2 pls.

Conger, D.H., 1986, Estimating magnitude and frequency of floods for Wisconsin urban streams: U.S. Geological Survey WaterResources Investigations Report 86-4005, 18 p.

Conger, D.H., 1981, Techniques for estimating magnitude and frequency of floods for Wisconsin streams: U.S. Geological Survey Water-Resources Investigations Open-File Report $80-1214,116$ p., 2 pls.

Conger, D.H., 1971, Estimating magnitude and frequency of floods in Wisconsin: U.S. Geological Survey Open-File Report, 200 p. 


\section{LIST OF CREST-STAGE GAGES}

\section{CHIPPEWA RIVER BASIN}

05357360

05359600

05361400

05361420

05361989

05363775

05364000

05364100

05364500

05366500

05367030

05367700

05370900
053674588

Bear River near Powell, WI

Price Creek near Phillips, WI

Hay Creek near Prentice, WI

Douglas Creek near Prentice, WI

Jump River tributary near Jump River, WI

Babit Creek at Gilman, WI

Yellow River at Cadott, WI

Seth Creek near Cadott, WI

Duncan Creek at Bloomer, WI

Eau Claire River near Fall Creek, WI

Willow Creek near Eau Claire, WI

Rock Creek tributary near Canton, WI

Lightning Creek at Almena, WI

Spring Creek near Durand, WI

\section{CENTRAL WISCONSIN RIVER BASIN}

05395020

05395100

05396300

05397600

05400025

05401800

05403397

05403700

Lloyd Creek near Doering, WI

Trappe River Tributary near Merrill, WI

Wisconsin River Tributary at Wausau, WI

Big Sandy Creek near Wausau, WI

Johnson Creek near Knowlton, WI

Yellow River Tributary near Pittsville, WI

Allen Creek at Canary Drive near Oakdale, WI

Dell Creek near Lake Delton, WI

\section{FOX-WOLF RIVER BASIN}

04072792

04073066

04073400

04074850

04075200

04079700

04081900

Tagatz Creek near Westfield, W

Grand River tributary near Manchester, WI

Bird Creek at Wautoma, WI

Lily River near Lily, WI

Evergreen Creek near Langlade, W

Spaulding Creek near Big Falls, WI

Sawyer Creek at Oshkosh, WI

\section{LAKE MICHIGAN BASIN}

04078891

04085145

04085400

040854105

04086310

04087100

04087200

04087250

Maple Creek near Sugar Bush, WI

Red River at CTH A near Dyckesville, WI

Killsnake River near Chilton, WI

Mud Creek at Marken Road near Valders, WI

Mink Creek at CTH S near Beechwood, W

Honey Creek at Milwaukee, WI

Oak Creek near South Milwaukee, W

Pike Creek near Kenosha, WI

\section{LAKE SUPERIOR BASIN}

04024400

04025200

04026200

04026300

04026450

04027200

Stony Brook near Superior, WI

Pearson Creek near Maple, W

Sand River Tributary near Red Cliff, WI

Sioux River near Washburn, WI

Bad River near Mellen, WI

Pearl Creek at Grandview, WI

\section{LOWER WISCONSIN RIVER BASIN}

05405600

054062391

Rowan Creek at Poynette, WI

Otter Creek at Kings Comer Road near Prairie du Sac, WI

05406605

05406754

05406854

05407039

05407200

Fancy Creek near Gillingham, WI

Willow Creek at CTH D near Loyd

Fennimore Fork near Fennimore, WI

Crooked Creek near Boscobel, WI
05413060 Martin Branch near Mount Ida, WI

05409270 Reads Creek at Riley Road near Readstown, WI

\section{MENOMINEE-OCONTO-PESHTIGO RIVER BASIN}

$04059900 \quad$ Allen Creek Tributary near Alvin, WI

04063640 North Branch Pine River at Windsor Dam near Alvin, WI

04067760 Peshtigo River near Cavour, WI

04069700 North Branch Oconto River near Wabeno, WI

$04071700 \quad$ North Branch Little River near Coleman, WI

04071800 Pensaukee River near Pulaski, WI

\section{PECATONICA-SUGAR RIVER BASIN}

$05413400 \quad$ Pigeon Creek near Lancaster, WI

05414213 Little Platte River near Platteville, WI

$05414900 \quad$ Pats Creek near Elk Grove, WI

05432055 Livingston Branch near Livingston, WI

05432300 Rock Branch near Mineral Point, WI

05433500 Yellowstone River near Blanchardville, WI

05436200 Gill Creek near Brooklyn, WI

\section{ROCK-FOX RIVER BASIN}

05424007 Gill Creek at Farmersville, WI

05425806 Mud Creek near Danville, WI

05430403 Fisher Creek Tributary at Janesville, WI

$05431400 \quad$ Little Turtle Creek at Allens Grove, WI

$05545100 \quad$ Sugar Creek at Elkhorn, WI

05545200 White River Tributary near Burlington, WI

$05548150 \quad$ North Branch Nippersink Creek Tributary near Genoa City, WI

\section{ST. CROIX RIVER BASIN}

05340300 Trade River near Frederic, WI

05341313 Bull Brook at CTH F near Amery, WI

05341900 Kinnickinnic River Tributary at River Falls, WI

05346294 Goose Creek at Beldenville, WI

05355315 Lost Creek near Waverly, WI

\section{TREMPEALEAU-BLACK RIVER BASIN}

05371800 Buffalo River Tributary near Osseo, WI

05371920 Buffalo River near Mondovi, WI

05379187 Pine Creek at Taylor Road near Taylor, WI

$05379288 \quad$ Bruce Valley near Pleasantville, WI

$05380900 \quad$ Poplar River near Owen, WI

05380970 Cawley Creek near Neillsville, WI

05381383 Glenn Creek near Millston, WI

$05382200 \quad$ French Creek near Ettrick, WI

$05387100 \quad$ North Fork Bad Axe River near Genoa, WI

\section{UPPER WISCONSIN RIVER BASIN}

$05391260 \quad$ Gudegast Creek near Starks, WI

05391950 Squaw Creek near Harrison, WI

05392150 Mishonagon Creek near Woodruff, WI

05392350 Bearskin Creek near Harshaw, WI

$05393640 \quad$ Little Pine Creek near Irma, WI

05394200 Devil Creek near Merrill, WI 


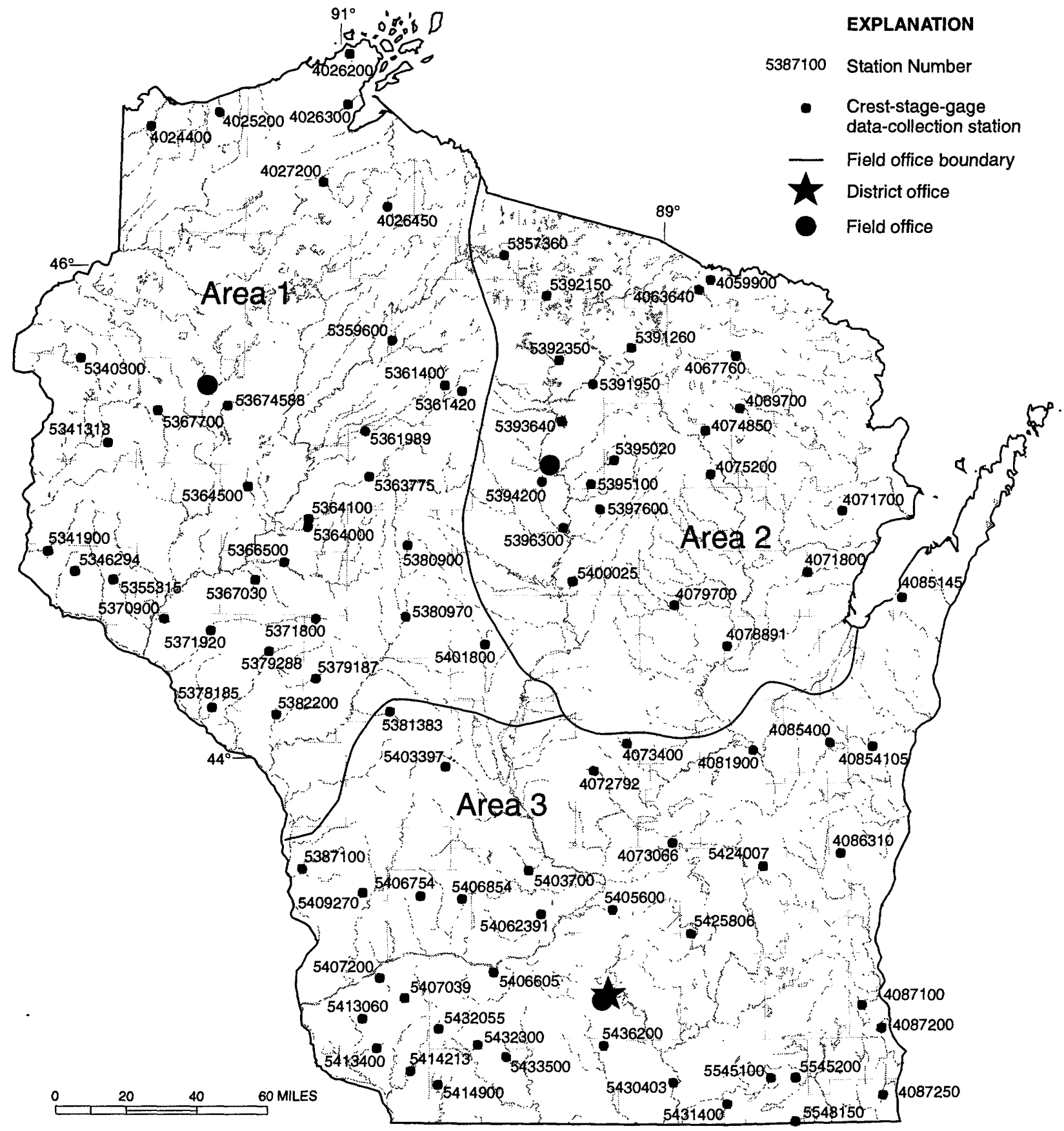

Figure 10. Location of crest-stage-gage data-collection stations. 


\section{MENOMINEE TRACE ELEMENT MONITORING, WI 12301}

PROBLEM: Maintaining the pristine quality of the Wolf River is extremely important to the Menominee Indian Tribe of Wisconsin and other tribes in the Upper Wolf River Basin. Information is needed to describe the current status of water quality and biotic conditions of the Wolf River within the Menominee Indian Reservation, and to determine the presence or absence of contaminants in water, sediments, and biota. Several years of data are available at USGS sites, including major ions, nutrients, and discharge data collected near the Menominee Indian Reservation boundaries. No data exist for trace element bioavailability and concentrations in water, aquatic biota, or streambed sediments at the other sites. A historical database is needed to evaluate present conditions and from which changes can be determined.

OBJECTIVE: The primary objective of the baseline monitoring is to establish a database describing water quality of the Wolf River near the upstream and downstream Menominee Indian Reservation boundaries. This database was specifically designed to (1) determine concentrations of specific trace elements in watercolumn samples; (2) determine concentrations of specific trace elements in samples of fish livers, caddisfly larvae, and fine streambed sediments at the sampled sites; and (3) determine particle-size fractions of the fine streambed sediments at the sampled sites.

APPROACH: Sampling will be conducted to determine trace element concentrations in water, aquatic biota, and streambed sediments at the Wolf River near Highway $M$ near Langlade and the Wolf River at County Highway VV near Keshena. Discharge data will be collected at the Wolf River near Langlade. Biological sampling will be conducted once per year at each of the sites.

Analyses of the water, biological, and sediment samples will include field parameters, major ions, nutrients, a broad suite of metals analyses, and analyses for selected pesticides. The USGS National Water-Quality Assessment protocols will be used for water, streambed sediments, and contaminants in tissues. Mercury analyses will be performed at the USGS Mercury Lab in Madison, Wisconsin, with all other analyses performed at the USGS National Water Quality Laboratory.

PROGRESS (July 1999 to June 2000): Water and biological sampling was completed in October 1999. The gaging station at Langlade was operated and discharge data published in the report, "Water Resources Data-Wisconsin". A report team was organized to work on a water-resources investigations report to analyze and interpret the data collected over the course of the study.

PLANS (July 2000 to June 2001): The water-resources investigations report titled, "Water Quality Assessment of the Wolf River, Menominee Indian Reservation, Wisconsin, 1986-98", will be published and distributed.
COOPERATORS:

Menominee Indian Tribe of Wisconsin

LOCATION:

Menominee Indian Reservation

PROJECT CHIEF:

Kevin D. Richards

Herbert S. Garn

PERIOD OF PROJECT: March 1996 to September 2000

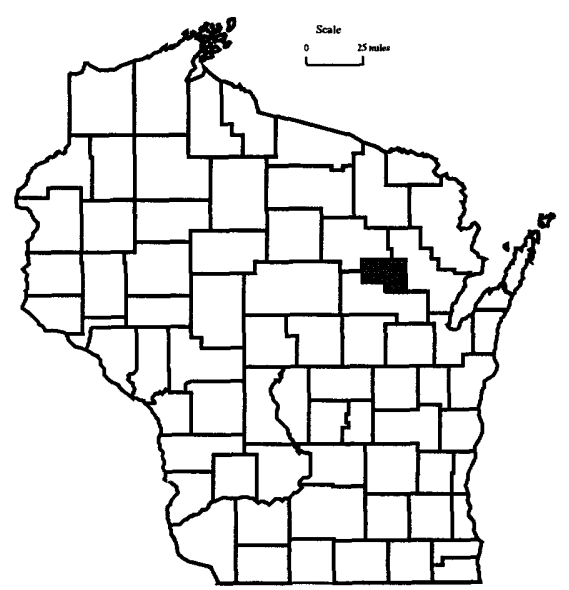




\section{COMPILATION AND ANALYSIS OF WATER-RESOURCES DATA NEAR THE ST. CROIX RESERVATION, WISCONSIN, WI 12303}

\section{COOPERATOR:}

St. Croix Tribe of Wisconsin

\section{LOCATION:}

Barron, Burnett, and

Polk Counties

\section{PROJECT CHIEF:}

David A. Saad

Dale M. Robertson

PERIOD OF PROJECT: January 1999 to September 2000
PROBLEM: The current and future health of several lakes, creeks, and rivers near the St. Croix Reservation, Wisconsin, is of concern to Tribal members. The Tribe is interested in documenting historical and current water quality, developing management plans for these water resources and protecting their lakes and watersheds.

OBJECTIVE: The objective is to provide the Tribe with a summary and analysis of available water-resources data near the St. Croix Reservation. This information will be used to aid in developing management plans for Big Round, Big Sand, Clam, Gaslyn, and Sand Lakes, Loon Creek, and the St. Croix and Yellow Rivers near the Reservation.

APPROACH: Water-resources information for the lakes, rivers and ground water in the study area will be compiled from available databases and through literature searches. Water-quality data will be obtained from databases maintained by the USGS, Wisconsin Department of Natural Resources, and USEPA. The compiled surface-water information will include physical, chemical, and biological characteristics of the lakes and streams and will be compared, where possible, to the land use and other environmental factors important to each watershed. This summary will provide a starting point for development of water-quality sampling strategies for the surface-water resources of interest to the Tribe.

PROGRESS (July 1999 to June 2000): All references, data, and GIS coverages for the study area have been compiled and analyzed. A report was prepared and sent for colleague and editorial review.

PLANS (July 2000 to September 2000): The final report will be published and distributed to the St. Croix Tribe.

\section{REPORTS}

Saad, David A., Water-resources-related information for the St. Croix Reservation and vicinity, Wisconsin (in review).

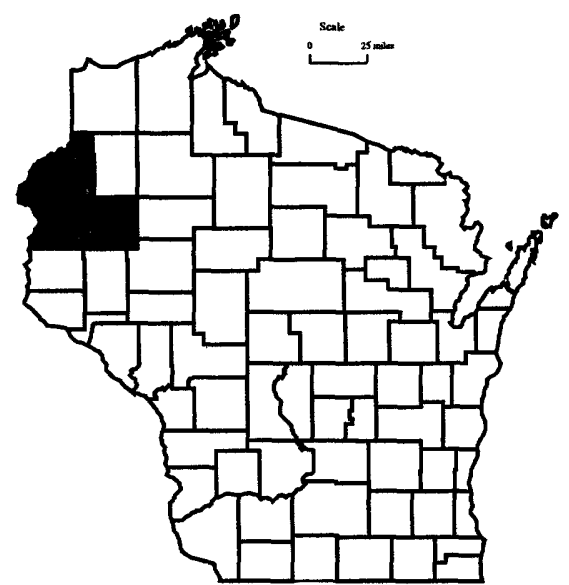




\section{ONEIDA NATION HYDROLOGIC INVESTIGATIONS, WI 12306}

PROBLEM: The Oneida Nation in Wisconsin has developed a seven-generation plan for their reservation that includes instituting land-use practices that will allow the surface-water system draining the reservation the opportunity to revert to its pre-colonial condition. The Oneida Nation needs continuing information regarding waterquality conditions entering and within their Nation's boundaries. The information is needed to determine trends in water quality and provide data to assess the Tribe's water resources.

OBJECTIVE: The objectives are to collect long-term data set at two sites to perform trend analysis for pesticides, nutrients and suspended sediment.

APPROACH: Sampling will be conducted at two sites to determine concentrations of nutrients, pesticides, and suspended sediment. Field parameters will also be collected and sampling will take place on a fixed interval. The National Water Quality Lab will do the analysis of the water samples. National Water Quality Assessment protocols will be followed in the collection and handling of the water-column samples. A staff person from the Oneida Nation Environmental Section will work with a USGS staff person in the collection of data.

PROGRESS (July 1999 to June 2000): Samples were collected at two sites monthly. Samples were analyzed for pesticides, nutrients and suspended-sediment concentrations. Data collected in 1999 were published in the report, "Water Resources Data-Wisconsin". A water-resources investigations report was published in March 2000. Bed-sediment samples were collected in August 1999. Surface-water-quality sampling began following approval of the Quality Assurance Project Plan by EPA.

PLANS (July 2000 to June 2001): Data from samples collected from October 1, 1999 through September 30, 2000, will be published in the report, "Water Resources Data-Wisconsin". Waterquality sampling will be conducted at three sites and continue indefinitely. A water-resources investigation report summarizing and interpreting the data that was collected as part of the baseline investigation will be prepared.

\section{REPORTS:}

Saad, David A., and Schmidt, Morgan A., 1999, Water-resourcesrelated information for the Oneida Reservation and vicinity, Wisconsin, U.S. Geological Survey Water-Resources Investigations Report 98-4266, $57 \mathrm{p}$.

\author{
COOPERATOR: \\ Oneida Nation of Wisconsin
}

LOCATION:

Oneida Indian Reservation, Wisconsin

\author{
PROJECT CHIEF: \\ Kevin D. Richards \\ Charles A. Peters
}

PERIOD OF PROJECT: August 1997 to September 2001 


\section{BEDROCK AQUIFER CHARACTERIZATION, NORTHERN BAD RIVER INDIAN RESERVATION, WI 12309}

COOPERATOR:

Bad River Band of Lake Superior Tribe of Chippewa Indians

\section{LOCATION:}

Ashland County

PROJECT CHIEF:

Charles Dunning

PERIOD OF PROJECT:

July 1996 to September 2001
PROBLEM: There is a general need to characterize and define the hydrology and water quality of reservation areas. Current and future site-specific investigations concerned with long-term waterresource and water-quality trends require an adequate regional hydrogeologic framework.

OBJECTIVE: The objective is to further define the local and regional ground-water flow system in the northern part of the Bad River Indian Reservation.

APPROACH: The aquifers will be characterized by drilling boreholes at three sites, conducting geophysical surveys and rock core analyses, and packer testing at selected borehole intervals. Water quality will be evaluated at selected sites and depths.

PROGRESS (July 1999 to June 2000): The data generated by bedrock aquifer testing have been evaluated. Information from all aspects of the investigation are being integrated and finalized. Characterization of the local and regional ground-water system in the northern part of the Bad River Indian Reservation is underway.

PLANS (July 2000 to June 2001): A water-resources investigations report presenting the data and interpretations is in preparation.

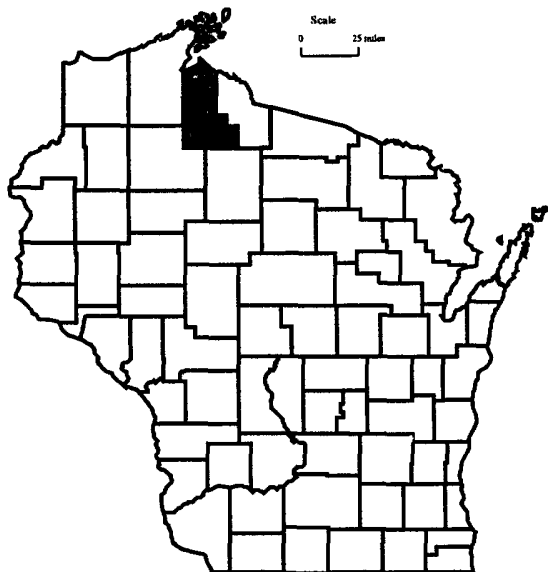




\section{DELINEATION OF THE AREA OF GROUND-WATER CONTRIBUTION AND THE TIMES OF TRAVEL TO COMMUNITY WATER SYSTEMS ON THE MENOMINEE INDIAN RESERVATION, WI 12312}

PROBLEM: The Menominee Indian Tribe is interested in determining the contributing areas and time of travel for water captured by wells for a number of community water systems in Menominee County, Wisconsin. The tribe's interest in well-head protection is heightened over concern about the presence of elevated nitrate levels in several wells.

OBJECTIVE: The objective of the study is to determine the contributing areas and time of travel for water captured by community wells. This information will be used by the Menominee Indian Tribe for water resource and well-head protection planning in community areas.

APPROACH: The USGS will construct a simple one-layer ground-water model to simulate the hydrologic conditions in an appropriate area around community wells. The ground-water model will be used to delineate the zone of ground-water contribution to the wells for 5-, 10- and 100-year times of travel, and define the associated area of contribution. The results of these investigations will provide the Tribe with the necessary information to plan a wellhead protection strategy for each community system.

PROGRESS (July 1999 to June 2000): Construction of the ground-water-flow model for the Zoar Community has been completed. The calibrated model has been used to identify the zone of contribution to the Zoar Community wells for 5-, 10-, and 100year times of travel. A septic source for the elevated nitrate measured in the community wells is consistent with the isotopic analysis of collected water samples.

PLANS (July 2000 to June 2001): Ground-water-flow modeling will be completed on three other communities on the Reservation-Middle Village, Onekewat and Redwing. In addition, a hydrogeologic study will be undertaken in the area around the town of Neopit, with a focus on the community wells and the sewagetreatment lagoons. The results of these investigations will be presented in a water-resources investigations report.
COOPERATOR:

Menominee Indian Tribe of Wisconsin

LOCATION:

Menominee County

PROJECT CHIEF:

Charles Dunning

PERIOD OF PROJECT: October 1998-Continuing

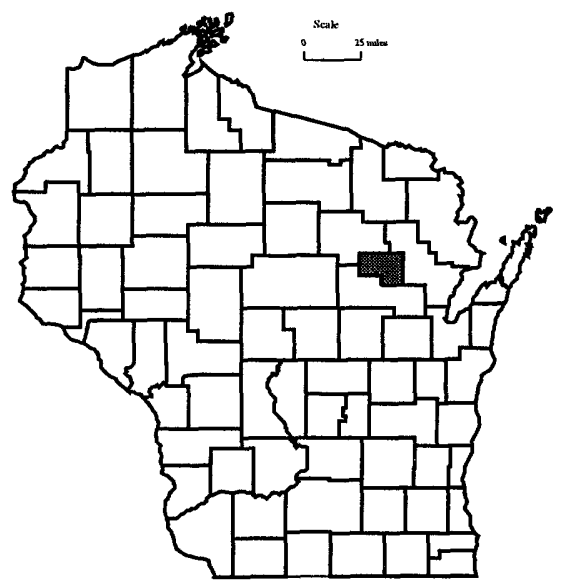




\section{LAKE WATER-QUALITY MONITORING, CHEMICAL AND BIOLOGICAL MONITORING OF SELECTED LAKES, WI 13300}

\section{LOCATION:}

Selected lakes in Wisconsin

PROJECT CHIEF:

William J. Rose

PERIOD OF PROJECT:

June 1983-Continuing

\section{COOPERATORS:}

In the 1999 water year:

Benedict/Tombeau, Big Hills, Buffalo, Eagle Spring, Little Cedar, Little Green, Lauderdale, Middle Genesee, Okauchee, Potter, Powers, and Wind Lake Districts; city of Muskego (Big Muskego and Little Muskego Lakes); townships of Casey (Big, Middle, and Lower McKenzie Lakes), Namekagon (Namekagon Lake), Sand Lake (Big Sissabagama), and Wascott (Whitefish Lake); and village of Oconomowoc Lake (Oconomowoc Lake)

In the 2000 water year:

Benedict/Tombeau, Big Cedar, Buffalo, Eagle Spring, Little Cedar, Little Green, Middle Genesee, Okauchee, Potter, Powers, and Wind Lake Districts; city of Muskego (Big Muskego and Little Muskego Lakes); townships of Sand Lake (Big Sissabagama), and Wascott (Whitefish Lake); and village of Oconomowoc Lake (Oconomowoc Lake)

PROBLEM: Lakes are a significant and valuable resource in the State of Wisconsin and are experiencing increased pressure from development and use. Many lakes do not have adequate water-quality information available for management of the lake. Hence, their water quality needs to be assessed and documented.

OBJECTIVE: Objectives of this project are to (1) determine the current water quality and trophic status of lakes, (2) assess the condition of specific lakes in comparison with other lakes of the same type in the region, and (3) build a quantitative database so that any detrimental changes or trends that might occur in the future can be detected quickly and evaluated objectively.

APPROACH: Water quality at each lake will be monitored in February, April, June, July, and August. Depth profiles of dissolvedoxygen concentration, temperature, $\mathrm{pH}$, and specific conductance will be determined. In April, the lakes will be sampled for analysis of the major anions and cations, nitrogen, and dissolved phosphorus. Secchi-depth measurements will be made for all months (except February), and total phosphorus and chlorophyll $a$ samples will be collected and analyzed. Lake stage will be measured at each of the five visits to the lake. 
PROGRESS (July 1999 to June 2000): Total phosphorus, chlorophyll $a$, dissolved oxygen, temperature, $\mathrm{pH}$, specific conductance, and Secchi-depth data were collected and analyzed for 25 lakes during the 1999 water year. In the 1999 water year, Big Hills and Lauderdale Lakes were added to the program. The locations of lakes included in the monitoring program for water years 1999-2000 are shown on the following map.

PLANS (July 2000 to June 2001): Twenty-one lakes will be monitored in the 2000 water year. Data collected during the year will be compiled and transmitted to the respective cooperator. The data will be prepared for publication in the annual report "Water Quality and Lake-Stage Data for Wisconsin Lakes, water year 2000".

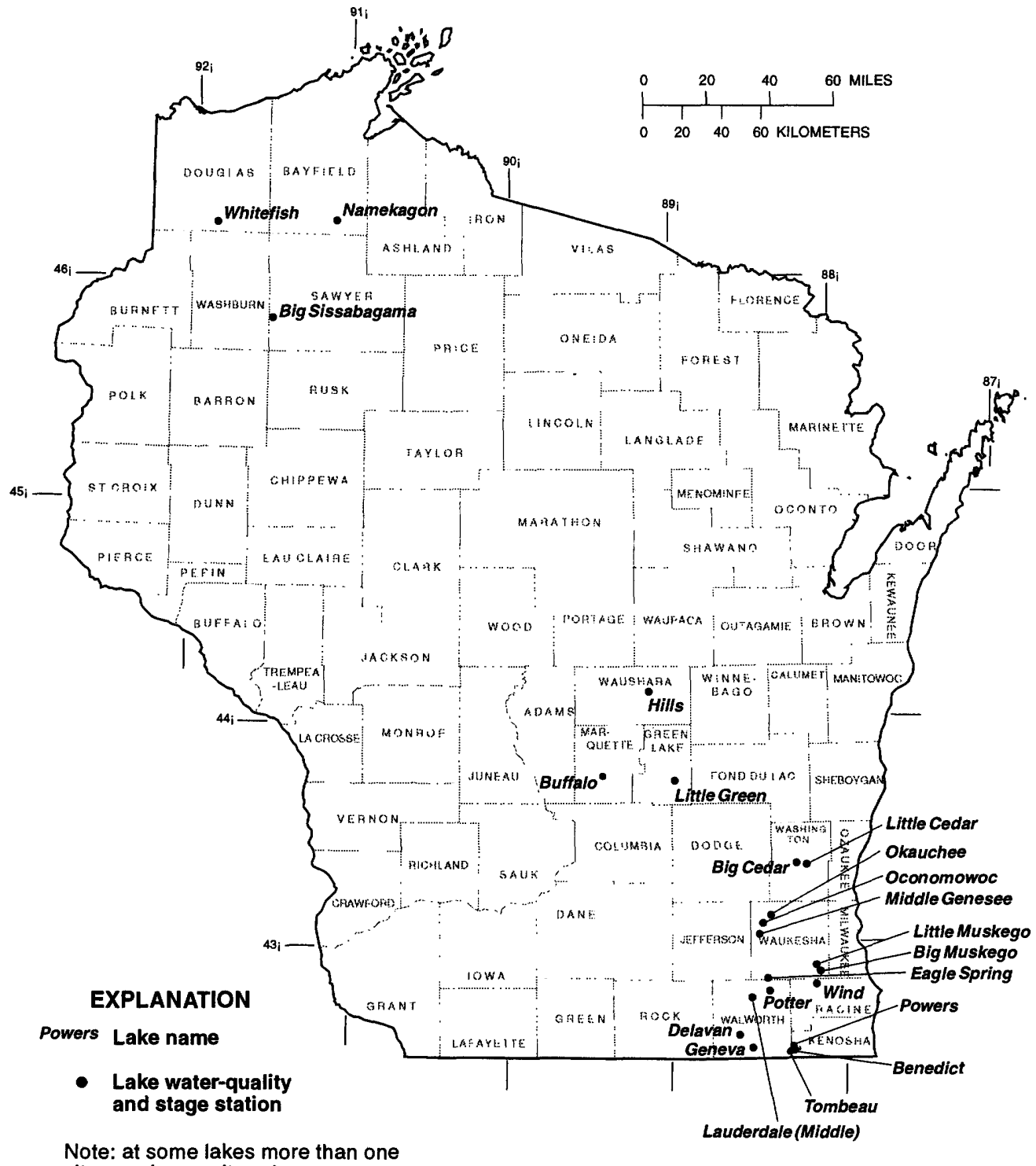

Note: at some lakes more than one site may be monitored. 


\section{FOX RIVER REMEDIATION, WI 14500}

\section{COOPERATOR: \\ Wisconsin Department of Natural Resources}

\section{LOCATION:}

Outagamie County

Brown County

\section{PROJECT CHIEF: Jeffrey Steuer}

\section{PERIOD OF PROJECT:} August 1998 to September 2001
PROBLEM: Several Fox River bottom sediment deposits are being considered for remediation based upon high PCB concentrations. The pilot remediation project at deposit "N" (Kimberly) began in November 1998 and, in August 1999, pre-dredge sampling commenced at the Sediment Management Unit (SMU) 56_57 (Green Bay). There is a need, as part of the Fox River Remediation Assessment Team (FRRAT) efforts, to monitor and collect environmental data before, during, and after the remediation operation.

OBJECTIVE: Monitoring and sampling will be conducted to meet the project Quality Assurance Project Plan objectives. The objectives are to (1) evaluate baseline conditions prior to dredging activities, (2) evaluate short-term impacts, including PCB mass fluxes during dredge activities, and (3) evaluate conditions following the completion of dredge-related activities.

APPROACH: Deposit "N"-The baseline investigation consists of water column samples collected at four upstream locations and four downstream locations prior to the commencement of dredging. Bottom sediment samples will be collected from a minimum of 30 locations in Deposit $\mathrm{N}$ and an intermediate zone located between the sediment deposit and the silt-containment barrier.

Evaluation of short-term impact includes water-column sampling at four upstream and four downstream locations, dredge slurry samples and continuous-flow monitoring, composite samples of all on-shore processing locations, composite samples of processed solids for landfill disposal, samples of filter media, and treated carriage water samples.

Evaluation of long-term impacts will include collecting sediment core samples from the same locations as the pre-dredge sample sites and an intermediate zone characterization using visual reconnaissance and sampling.

SMU 56_57-The baseline investigation consists of water-column samples collected at four upstream locations and five downstream locations prior to the commencement of dredging.

Evaluation of short-term impact includes water-column sampling at four upstream and five downstream locations, dredge slurry samples with continuous-flow monitoring and composite samples of processed and treated carriage water samples.

PROGRESS (July 1999 to June 2000): Deposit "N"-Preand post-dredge cores have been collected and processed at 30 locations along with the intermediate zone. Over 90 PCB samples, 800 TSS samples, and over 6,400 water-quality measurements have been collected at the water-column sites. Shore-side (remediation process) samples and slurry flow data have been collected for 29 continuous days. The USGS mercury lab has completed the bottom sediment and remediation process sample analyses. The data analyses and draft report have been written evaluating the water-column transport and the shore-side processes. 
SMU 56_57-Over 90 PCB samples, 800 TSS samples, and over 6,400 water-quality measurements have been collected at the watercolumn sites. Assistance was provided in the slurry sampling and five 80 -liter effluent samples were processed. Data analysis has commenced.

PLANS (July 2000 to June 2001): SMU 56_57 data analysis and report writing will be conducted in conjunction with the FRRAT. 


\section{TECHNICAL AND FIELD SUPPORT FOR U.S. ENVIRONMENTAL PROTECTION AGENCY, REGION 5, WI 16400}

\section{COOPERATOR:}

U.S. Environmental Protection Agency, Office of Superfund

\section{LOCATION:}

EPA-Region 5 (Wisconsin, Illinois, Michigan, Minnesota, Indiana and Ohio)

\section{PROJECT CHIEF:}

Ty Sabin

PERIOD OF PROJECT: November 1988-Continuing

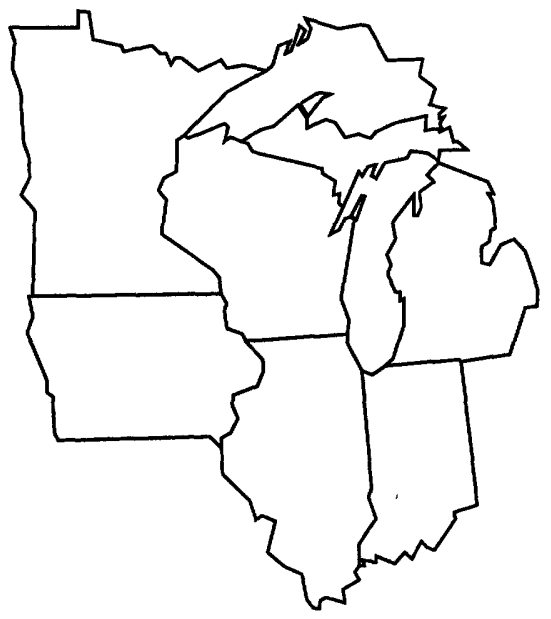

PROBLEM: The U.S. Environmental Protection Agency, Region 5, has requested that the Wisconsin District provide technical assistance with hydrogeological characterization of contaminated sites within the Region. These sites may be designated as Superfund or brownfields sites.

OBJECTIVE: The objectives are to provide the requested assistance and add to the understanding of the ground-water hydrology in the Region.

APPROACH: The Wisconsin District will provide hydrological, geophysical and field expertise to EPA activities in the Region. In addition, drilling, monitoring well installation, and aquifer testing will be conducted by Wisconsin District personnel in support of EPA activities.

PROGRESS (July 1999 to June 2000): Two reports have been published. Recent field activities have been conducted in Toledo, Ohio; Moline, Illinois; Detroit, Michigan; and Ashland and Milwaukee Counties, Wisconsin.

PLANS (July 2000 to June 2001): Two additional reports are now in preparation. Ground-water flow modeling is underway in support of the city of Milwaukee's Brownfield Demonstration Pilot Project in the Menomonee Valley. Assistance will continue to be provided at sites in EPA Region 5 upon request.

\section{REPORTS:}

Batten, W.G., Yeskis, D.J., and Dunning, C.P., 1999, Hydrogeologic properties of the Ordovician Sinnipee group at test well BN483, Better Brite Superfund site, DePere, Wisconsin, U.S. Geological Survey Water-Resources Investigations Report 99-4199, $19 \mathrm{p}$.

Brown, T.A., and Dunning, C.P., 1997, Structure, depth and thickness of the Galena-Platteville bedrock unit in the subcrop area of Illinois and Wisconsin, U.S. Geological Survey Water-Resources Investigations Report 97-4054-C, 3 plates.

Batten, W.G., Brown, T.A., Mills, P.C., and Sabin, T.J., 1997, Rockstratigraphic nomenclature, lithology, and subcrop area of the Galena-Platteville Bedrock unit in Illinois and Wisconsin, U.S. Geological Survey Water-Resources Investigations Report 974054-B.

Brown, T.A., Dunning, C.P., and Batten, W. G., 1997, Bibliography of selected references on the hydrogeologic and chemical properties of the Galena-Platteville Bedrock Unit in Illinois and Wisconsin, 1877-1997, U.S. Geological Survey Water-Resources Investigations Report 97-4054-A, 44 p. 


\section{TRENDS IN WATER QUALITY AND STREAM HABITAT FOR PRIORITY WATERSHEDS, WI 17202-17204, 17213}

PROBLEM: An evaluation strategy is needed to assess the effectiveness of nonpoint-source pollution control measures in priority watersheds. Several important processes require research including the role of ground water in nonpoint-source contamination, factors leading to dissolved-oxygen reduction in a stream during runoff events, and the impact of management practices on bedload transport. Several techniques need to be developed and/or refined, such as detecting trends in stream-water chemistry, sampling of fish and fish habitat, relation between fish/fish habitat and changes resulting from watershed management practices, and use of habitat models for determining impact of watershed management on fish populations.

OBJECTIVE: The overall objective of this project is to determine the trends in water quality for 10 sites during and after implementation of improved land-management practices in 7 priority watersheds.

APPROACH: Ten streams were selected in seven different priority watersheds. Continuous-record streamflow, water temperature, and dissolved-oxygen gaging stations were installed at each stream site. Water-quality samples will be collected during events and low flows and analyzed for selected constituents. Landuse inventories will be taken each year to help determine the cause of any changes in water quality.

PROGRESS (July 1999 to June 2000): Streamflow and water-quality monitoring were continued at one site in the priority watersheds. Water-quality loads were calculated for selected parameters and storm periods. All the data were summarized and published in the report "Water-Resources Data-Wisconsin". Landuse inventories were completed for each basin.

PLANS (July 2000 to June 2001): Streamflow and waterquality monitoring will be continued at one site. Two sites will be monitored for streamflow and water quality beginning in October 2000 , with the possibility of a third site. Water-quality loads for selected parameters and storm periods will be calculated and compared to data collected in previous years. The data will be analyzed to determine if there are any apparent trends in water quality during implementation of best management plans. At one site, water-quality samples will be collected weekly during the period of April-October, biweekly in March and November, and monthly during December, January, and February. Land use will be updated for each basin. Report on post monitoring of two sites discontinued in 1998.

\section{REPORTS:}

Wierl, J.A., Giddings, E.M., and Bannerman, R.T., 1998, Evaluation of a method for comparing phosphorus loads from barnyards and croplands in Otter Creek Watershed, Wisconsin, U.S. Geological Survey Fact Sheet 168-98, 4 p.
COOPERATOR:

Wisconsin Department of

Natural Resources

LOCATION:

Priority watersheds in Brown, Buffalo, Dane, Grant, Milwaukee and Sheboygan Counties

PROJECT CHIEF:

David J. Graczyk

Steven R. Corsi

Judy A. Wierl

PERIOD OF PROJECT:

October 1990-Continuing 
Corsi, S.R., Graczyk, D.J., Owens, D.W., and Bannerman, R.T., 1997, Unit-area loads of suspended sediment, suspended solids, and total phosphorus from small watersheds in Wisconsin: U.S. Geological Survey Fact Sheet 195-97, 4 p.

Rappold, K.F., Wierl, J.A., and Amerson, F.U., 1997, Watershed characteristics and land management in the nonpoint-source evaluation monitoring watersheds in Wisconsin: U.S. Geological Survey Open-File Report 97-119, 39 p.

Wierl, J.A., Rappold, K.F., and Amerson, F.U., 1996, Summary of the land-use inventory for the nonpoint-source evaluation monitoring watershed in Wisconsin: U.S. Geological Survey OpenFile Report 96-123, 23 p.

Greb, Steven R., and Graczyk, David J., 1995, Frequency-duration analysis of dissolved-oxygen concentrations in two southwestern Wisconsin streams, Water Resources Bulletin v. 31, no. 3, p. 431-438.

Walker, John F., and Graczyk, David J., 1993, Preliminary evaluation of effects of best management practices in the Black Earth Creek, Wisconsin, priority watershed: Water Science Technology, v. 28 , no. 3-5, p. 539-548. 


\section{BEST MANAGEMENT PRACTICE EVALUATION, WI 17206}

PROBLEM: To date, the effectiveness of best management practices (BMPs) in Wisconsin has not been determined. The natural variability of water-quality data complicates the detection of changes due to BMP implementation. Research is needed to identify techniques for detecting changes due to BMP implementation and applying the techniques to before and after data.

OBJECTIVE: The objective is to investigate statistical analysis techniques for assessing trends in water quality due to Best Management Practice (BMP) implementation using data from other states. The effectiveness of BMPs in two urban basins and seven rural basins in Wisconsin will be determined using the identified statistical techniques.

APPROACH: A comprehensive literature search will be conducted to identify viable statistical analysis techniques and needs for method modification or development. Data for several rural and urban basins in other states will be compiled and used to test the selected techniques. Storm loads of total-suspended solids and total phosphorus will be computed and used along with rainfall data and land-use information to assess the effectiveness of the BMPs in several basins in Wisconsin.

PROGRESS (July 1999 to June 2000): Storm-load data through 1998 water year was compiled for annual report. Annual report was completed and sent out for review. Analysis of pre- and post-BMP data for Brewery and Garfoot Creeks began. Final report for Black Earth Creek watershed was started.

PLANS (July 2000 to June 2001): The annual report describing results of statistical analysis for data collected through the 1998 water year will be published. Report describing final results for the Black Earth Creek watershed will be completed and published.

\section{REPORTS:}

Owens, D.W., Corsi, S.R., and Rappold, K.F., 1997, Evaluation of nonpoint-source contamination, Wisconsin: selected data for water year 1995, U.S. Geological Survey Open-File Report 96661A.

Walker, J.F., Graczyk, D.J., Corsi, S.R., Owens, D.W., and Wierl, J.A., 1995, Evaluation of nonpoint-source contamination, Wisconsin: land-use and best management practices inventory, selected streamwater-quality data, urban-watershed quality assurance and quality control, constituent loads in rural streams, and snowmelt-runoff analysis, water year 1994: U.S. Geological Survey Open-File Report 95-320, 21 p.

Corsi, S.R., Walker, J.F., Graczyk, D.J., Greb, S.R., Owens, D.W., and Rappold, K.F., 1995, Evaluation of nonpoint-source contamination, Wisconsin: selected streamwater-quality data, landuse and best-management practices inventory, and quality assurance and quality control, water year 1993: U.S. Geological Survey Open-File Report 94-707, 57 p.
COOPERATOR:

Wisconsin Department of

Natural Resources

LOCATION:

State of Wisconsin

PROJECT CHIEF:

John F. Walker

PERIOD OF PROJECT:

October 1989 to September 2001

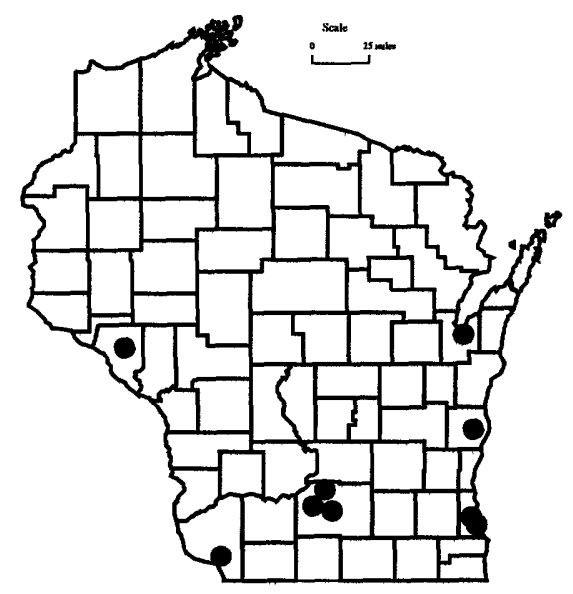


Walker, J.F., 1994, Statistical techniques for assessing water-quality effects of BMPs, ASCE J. of Irrigation and Drainage Engineering, v. 120 , no. 2 , p. 334-347.

Walker, J.F., and Graczyk, D.J., 1993, Preliminary evaluation of effects of best management practices in the Black Earth Creek, Wisconsin, priority watershed: Water Science and Technology, v. 28 , no. $3-5$, p. $539-548$.

Walker, J.F., 1993, Techniques for detecting effects of urban and rural land-use practices on stream-water chemistry in selected watersheds in Texas, Minnesota, and Illinois: U.S. Geological Survey Open-File Report 93-130, 16 p.

Graczyk, D.J., Walker, J.F., Greb, S.R., Corsi, S.R., Owens, D.W., 1993, Evaluation of nonpoint-source contamination, Wisconsin: Selected data for 1992 water year: U.S. Geological Survey Open-File Report 93-630, 48 p. 


\section{SINGLE SOURCE SITES, WI 17214}

PROBLEM: Much work has been done to assess the effectiveness of nonpoint-source pollution-control strategies known as best management practices (BMPs). Most of this work to date has had a basin-wide scope and is focused on evaluating the cumulative effectiveness of several different types of BMPs. Research targeted at evaluating the effectiveness of a single type of BMP would assist resource managers responsible for planning BMP implementation programs.

OBJECTIVE: The objective is to determine the significance of a single nonpoint-pollution source and evaluate the effectiveness of BMPs in treating that same source.

\begin{abstract}
APPROACH: Water-quality samples will be collected upstream and downstream from a single nonpoint-pollution source before and after implementation of BMPs. Water-quality samples are generally collected biweekly during open-water periods, and monthly during the winter months. In addition, water-quality samples are collected with automated water samplers during selected periods of storm runoff. Water-surface levels are continuously monitored at the sites, and a continuous discharge record is determined from water-surface/discharge relations.
\end{abstract}

Two barnyard-runoff sites have been fully investigated-Otter Creek in the Sheboygan River Priority Watershed and Halfway Prairie Creek in the Black Earth Creek Priority Watershed. The study concluded that implementation of barnyard BMPs at each site has significantly reduced the loadings of most constituents coming from the barnyards. Currently two additional sites are being investigatedParsons Creek in the Lake Winnebago Priority Watershed and Hutchinson Creek in the Buffalo River Watershed. Each of these sites is designed to evaluate both a barnyard BMP and a streambank erosion BMP.

PROGRESS (July 1999 to June 2000): Samples were collected for two storm-runoff periods at Parsons Creek. Streambank stabilization work was completed in September 1999. Water samples for one snowmelt period have been collected for the first post-BMP period. Water discharge, water temperature, rainfall records and water-quality loads have been worked up for water years 1998 and 1999 for the upstream, middle, and downstream sites and will be published in the 2000 data report.

Samples were collected for four storm-runoff periods at Hutchinson Creek. Baseflow samples were collected according to schedule and measurements of streamflow were made when appropriate.
COOPERATOR:

Wisconsin Department of Natural Resources

LOCATION: State of Wisconsin

PROJECT CHIEF:

Todd D. Stuntebeck

PERIOD OF PROJECT: March 1994-Continuing

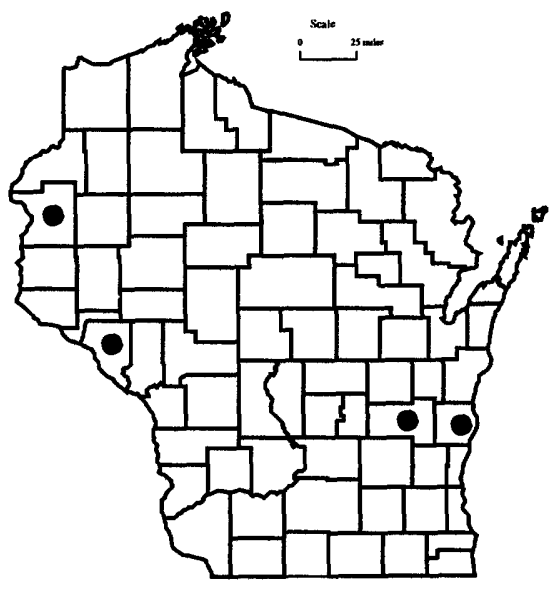


PLANS (July 2000 to June 2001): Biweekly baseflow and storm-runoff samples will be collected at Parsons Creeks. Stormevent data analysis for pre-BMP period at Parsons Creek will begin. Sampling will be discontinued at Hutchinson Creek after June 1,2000, due to site limitations. Equipment will be installed and sampling will begin at a site in LaCrosse County to evaluate the effectiveness of rotational grazing.

\section{REPORTS:}

Stuntebeck, T.D., and Bannerman, R.T., 1998, Effectiveness of barnyard best management practices in Wisconsin: U.S. Geological Survey Fact Sheet 051-98, 4 p.

Stuntebeck, T.D., 1995, Evaluating barnyard best management practices in Wisconsin using upstream-downstream monitoring: U.S. Geological Survey Fact Sheet 221-95, 4 p. 


\section{MULTI-STREAM EXPERIMENTAL DESIGN, WI 17223}

PROBLEM: The amount of best management practice (BMP) implementation at evaluation monitoring sites is currently much less than anticipated, and implementation is taking longer than expected. Results on a shorter time scale are needed to evaluate the overall nonpoint-source program.

OBJECTIVE: Objective is to investigate feasibility of sampling a large number of sites (20-60) for a short period of time (1-2 years) to determine the effectiveness of BMPs.

APPROACH: The sites to be considered are chosen to cover a wide range of BMP implementation. For selected evaluation-monitoring sites, annual loads will be computed with a reduced data set and compared to the actual load to determine uncertainty in annual loads for a particular sampling scheme. A statistical analysis will determine the minimum number of sites needed to demonstrate a significant relation between load reduction and BMP implementation.

PROGRESS (July 1999 to June 2000): Data collection at the eight index stations was completed through November 1999. Daily streamflow records and annual sediment and phosphorus loads at the eight index sites were estimated. The accuracy of estimated daily records from the index-site method was evaluated.

PLANS (July 2000 to June 2001): The accuracy of annual loads using a combination of index sites and the sampling strategies determined previously (Robertson and Roerish) was evaluated. Overall statistical analysis evaluating multi-stream approach for evaluation of BMP effectiveness was performed. Results will be published in an open-file report.

\section{REPORTS:}

Robertson, Dale M., and Roerish, Eric D., Influence of different sampling strategies on load estimations for small streams, journal article (submitted to Water Resources Research).
COOPERATOR:

Wisconsin Department of Natural Resources

\section{LOCATION:}

Fond du Lac, Manitowoc, Ozaukee, Sheboygan, Washington, and Walworth Counties

\section{PROJECT CHIEF:}

John F. Walker

\section{PERIOD OF PROJECT: October 1997 to June 2002}

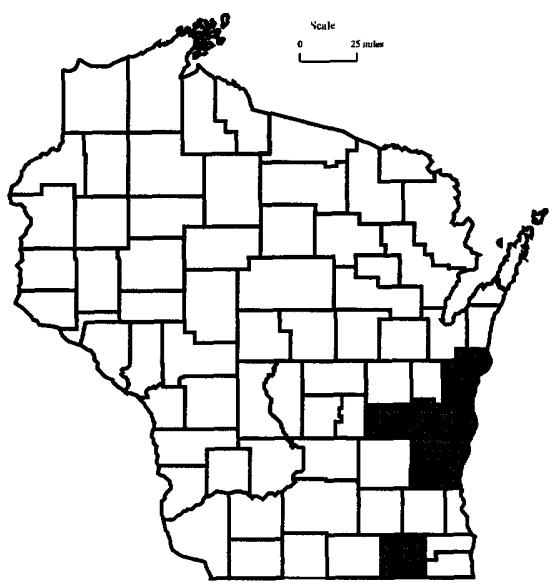




\section{HYDROLOGY AND WATER QUALITY OF THREE PASTURES IN SOUTHWESTERN WISCONSIN, WI 17229}

COOPERATOR:

Wisconsin Department of Natural Resources

LOCATION

Sauk County

PROJECT CHIEF:

David J. Graczyk

PERIOD OF PROJECT: October 1997 to September 2001
PROBLEM: Nonpoint-source pollution is a major concern in Wisconsin. There are approximately 24,000 dairy farms in Wisconsin which may be sources of sediment, nutrients and pesticides to surface and ground water. Managed Intensive Rotational Grazing (MIRG) is a system that uses pastures as a major source of feed for milking cows (Jackson-Smith and others, 1996). MIRG farmers rely on pastures for their dairy herds' forage needs and move their cows to a new pasture at least once a week (Jackson-Smith and others, 1996). In 1992, roughly 7 percent of Wisconsin dairy farms used MIRG but, in 1994, 14 percent of Wisconsin dairy farms used MIRG (Jackson-Smith and others, 1996). MIRG can be used as a best management practice (BMP) and may reduce the amount of sediments, nutrients and pesticides to receiving waters. In a study in Oklahoma, rotational grazed pastures evidenced a reduction in average annual runoff and sediment discharges when compared to a continuously grazed basin (Menzel and others, 1978).

This study will compare surface-water runoff and water quality from three small pastured watersheds. The pastures will be located at the USDA Dairy Forage Research Center at Prairie du Sac.

OBJECTIVE: The overall objective of this study is to determine differences in quantity and quality of surface-water runoff from three different pasture-management strategies. These strategies consist of a variety of practices which are available to pasture managers, both during the growing and dormant seasons. Combinations of management practices have been chosen to represent commonly used strategies. In addition to examining differences in overall management strategies, differences related to individual seasonal practices will be determined. A secondary objective will be to determine a water budget for each pasture. The water budget will be determined by measuring surface-water runoff and precipitation. Evaporation and transpiration will be estimated by using empirical equations and ground-water flow will be estimated as a residual.

APPROACH: The management practices to be examined include (1) intensive rotational grazing and continuous grazing during the growing season; (2) pasture "stockpiling" during late summer and continued grazing throughout the summer; and (3) two outwintering practices and no outwintering.

An artificial hydraulic control was installed at each pasture outlet. The control is a three-inch Parshall flume. Each site will use a pressure transducer to measure stage and a CR-10 data recorder. Daily, monthly and annual surface-water runoff will be calculated at each pasture. 
A tipping-bucket rain gage was installed at each site. Evapotranspiration will be estimated using empirical equations. Air temperature and solar radiation will be collected at one of the pastures for use in the evapotranspiration calculation. Meteorological data collected at the USDA Research Station will supplement data collected at this pasture. Ground-water flow will be calculated as a residual. An ISCO automatic water-quality sampler was installed at each site. The sampler will collect discrete samples. These samples will be composited on a flow-weighted basis. One composite sample per rainfall or snowmelt event will be sent to the Wisconsin State Laboratory of Hygiene for analysis. All events will be monitored. Approximately 5-10 samples per pasture will be collected. All samples will be analyzed for soluble reactive phosphorus, total phosphorus, ammonia nitrogen, nitrate and nitrite nitrogen, total kjeldahl nitrogen, total suspended solids, and volatile suspended solids.

PROGRESS (July 1999 to June 2000): Three small basins were monitored for continuous streamflow and rainfall. One runoff sample was collected at one site, five samples at another site and four runoff samples at the other site. Total-phosphorus concentrations ranged from $0.142 \mathrm{mg} / \mathrm{L}$ to $1.48 \mathrm{mg} / \mathrm{L}$ at the three sites. The storm loads for total phosphorus ranged from $0.003 \mathrm{lb}$ to $0.18 \mathrm{lb}$. The suspended-solids concentrations ranged from $5 \mathrm{mg} / \mathrm{L}$ to 1440 $\mathrm{mg} / \mathrm{L}$ at the three sites with suspended-solids loads ranging from $0.03 \mathrm{lb}$ to $116 \mathrm{lb}$. Samples of the runoff were a result of early winter rainfall and snowmelt events. No summer rainstorms or intense thunderstorms resulted in runoff. All data was summarized and published in the report "Water Resources Data-Wisconsin, 1999".

PLANS (July 2000 to June 2001): Monitoring at all three sites will be continued. Water-quality samples will be collected at the three sites for all storms that produce runoff and water-quality loads will be calculated for each storm. Animal grazing will be allowed according to the Managed Intensive Rotational Grazing Plan for each site. All streamflow and water-quality data will be summarized and published in the annual report "Water Resources Data-Wisconsin, 2000". 
COOPERATOR:

Marathon County Highway

Department

\section{LOCATION:}

Marathon County

PROJECT CHIEF:

Peter E. Hughes

PERIOD OF PROJECT:

May 1998-Continuing

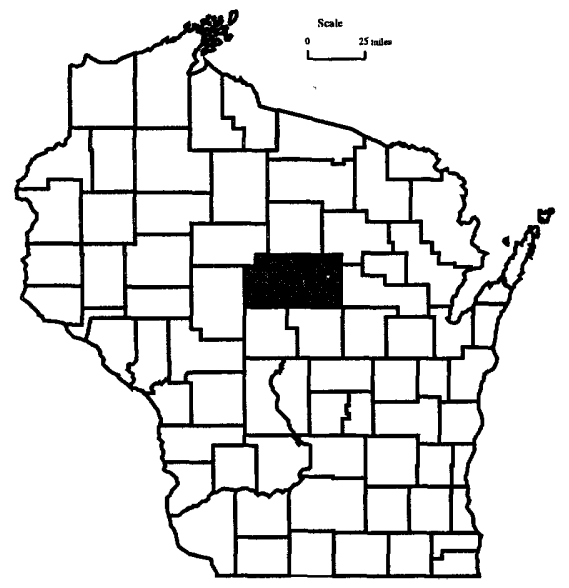

PROBLEM: Bridge scour has become a topic of nationwide interest in recent years but has not been identified as a serious problem for many bridges in Wisconsin. The Balsam Road bridge over the Big Eau Pleine River in Marathon County is one bridge, however, which has already been severely scoured with pier footings and pilings exposed. The scour hole is concentrated around the bridge location, beginning at approximately 200 feet upstream to approximately 200 feet downstream. An engineering assessment indicates that the 100-year return period discharge could undermine the east abutment and piers 1 and 2 and scour close to pile tip elevations on Pier 3 and the west abutment.

OBJECTIVE: The objective of this study is to install acoustic transducers to continuously monitor the scour depth on the upstream and downstream sides of the piers at the east side of the bridge. Discharge data from the streamflow gage at Stratford will be used to provide a high flow alert to the USGS and the Marathon County Highway offices to allow closure of the bridge if scour depths increase to dangerous levels.

APPROACH: Acoustic transducers will be attached to the upstream and downstream faces of the most eastern pier on the Balsam Road bridge. The scour depth data will be recorded on a datalogger and telemetered to the USGS office in Middleton, Wisconsin. This information will be automatically uploaded to the World Wide Web home page for the USGS Wisconsin District (http://wi.water.usgs.gov). A voice modem will be installed at the Big Eau Pleine River streamflow gage at Stratford and will be programmed to provide an alert to the Marathon County Highway Department and USGS offices that a flood event is occurring. This alert will provide the opportunity to closely monitor the scour depths to determine whether the bridge should be closed due to hazardous conditions.

PROGRESS (July 1999 to June 2000): Scour depth was monitored. Data has been made available on the World Wide Web.

PLANS (July 2000 to June 2001): Monitoring will continue through June 2001. 


\section{EVALUATING IMPROVED STREET SWEEPING FOR ENHANCING WATER QUALITY IN HIGHWAY RUNOFF IN MILWAUKEE, WI 17231}

PROBLEM: The Wisconsin Department of Transportation (WDOT) is required to control the quality of runoff from roadways under their control as part of the National Pollutant Discharge Elimination System (NPDES). One way to control roadway runoff quality is to use street sweeping to remove pollutants before they are entrained in runoff. This option may be more cost effective than structural BMPs since WDOT already conducts street sweeping and would only need to increase the frequency of sweeping and use an improved sweeper.

OBJECTIVE: The primary objective of the investigation is to determine if water-quality benefits are realized by improved street sweeping and, if so, to what degree. Secondary objectives are to (1) develop accumulation curves for solids deposited on freeways in the greater Milwaukee area, (2) use solids accumulation curves and water-quality data to calibrate the SIMPTM model, (3) characterize the variability in freeway runoff quality, and (4) characterize pollutant loading with and without the street-sweeping program.

APPROACH: This study will use a paired-basin approach. The test basin will be swept periodically with an Enviro-Whirl street sweeper and the control basin will never be swept. Regression relations will be determined between the test and control basins for both sweeping and non-sweeping periods. If the slope and intercept of the regression relations are significantly different between the sweeping and non-sweeping periods, the difference will be attributed to street sweeping.

Baseline periods, where no sweeping occurs in either the test or control basin, will be used to define pollutant load and concentration relations for runoff events between the basins. These relations will then be compared to pollutant load and concentration relations found between the basins during test periods. Sweeping periods will have the test basin swept at a rate of once per week and the control basin unswept. The sweeping and non-sweeping schedule has been selected to provide an equal number of sweeping versus nonsweeping samples from frontal, convective and winter runoff events.

PROGRESS (July 1999 to June 2000): Flow composite samples have been collected from 32 runoff events at both the test and control basins. Most of the samples were collected during periods when the street sweeper was being used. In addition, street dirt samples have been collected biweekly from the street shoulder surface from both basins. These samples are being weighed and sieved to determine if the mass and particle-size distribution of the street dirt is affected by the street-sweeping regimen.

PLANS (July 2000 to April 2001): Runoff event sampling and street dirt sampling will continue through September 2000. The data will be compiled and a data report written and given to WDOT in February 2001. The USGS will then assist the WDOT in preparation of an interpretive report.
COOPERATOR:

Wisconsin Department of

Transportation

LOCATION:

Milwaukee County

PROJECT CHIEF:

Robert J. Waschbusch

PERIOD OF PROJECT: October 1998 to April 2001

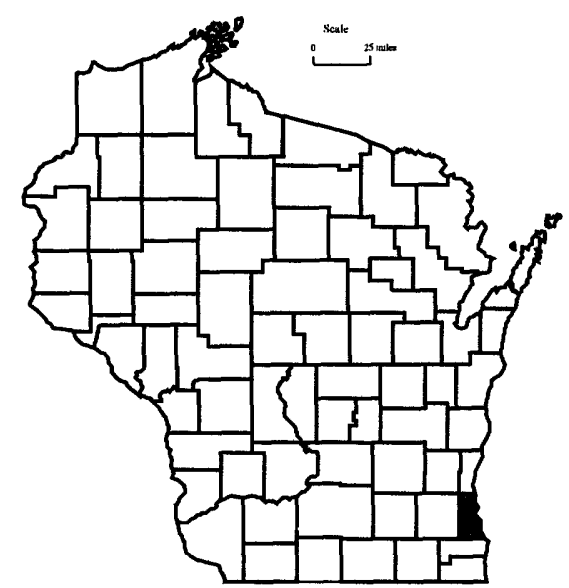




\section{QUANTIFICATION OF SOLIDS LOADING FROM RESIDENTIAL AND COMMERCIAL CONSTRUCTION SITES IN DANE COUNTY, WISCONSIN, WI 17232}

COOPERATOR:

Dane County Land Conservation Department

LOCATION:

Madison and Sun Prairie

PROJECT CHIEF:

David W. Owens

PERIOD OF PROJECT:

May 1998 to December 2000

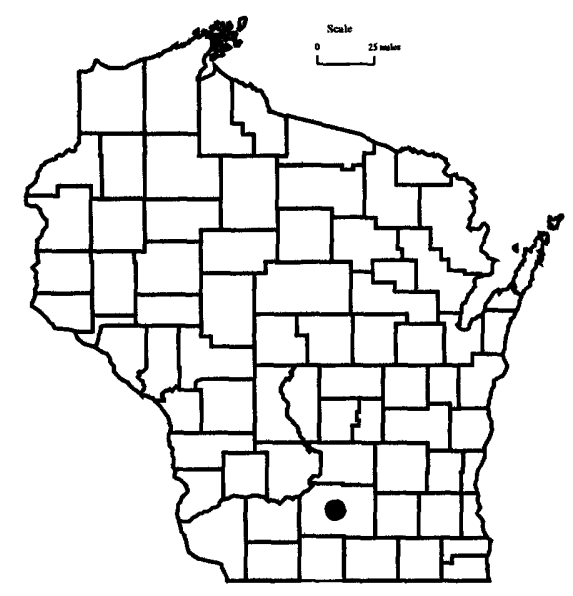

PROBLEM: Construction site erosion has been identified as a significant source of suspended solids in runoff in many parts of the United States (Hagman and others, 1980; Yorke and Herb, 1976; Becker, et al., 1974). The literature reflects studies done on largescale projects including highway construction and plat development. There is limited information on the smaller residential and commercial sites, which typically range in size from 1 to 5 acres.

The project is designed to provide both national and local benefits. This study would provide the USEPA with specific data relating to the impact of sites less than 5 acres (small sites), which may facilitate implementation of Phase II of the USEPA National Pollution Discharge Elimination System (NPDES) standard for pollution control from small (less than five acre) construction sites.

OBJECTIVE: The four objectives for this project are to (1) quantify solids loading from one residential construction site and one commercial construction site during all construction phases from pre-construction through final landscaping, (2) determine whether the "first flush phenomenon" is responsible for significant sediment loading during storm events, (3) determine the particlesize distribution of the transported sediment during different stages of the hydrograph to determine preferential delivery of particles and (4) compare USLE/RUSLE modeled results to monitored data.

APPROACH: Discharge and associated solids concentrations and loads will be measured at two small, hydrologically-isolated sites. One residential and one commercial construction site in Dane County, Wisconsin, will be monitored. Data will be collected prior to construction, during construction, and after final landscaping so that a complete time-series of solids loading will be obtained during all phases of building construction. Photographic documentation will occur during all phases.

Discharge will be measured using a Parshall flume equipped with a transducer and datalogger in a drainage ditch down gradient of the residential site that is the single discharge point for runoff. Due to the potential variation on the larger commercial site, the sampling location will be selected based on the best available collection point. Samples for analysis of suspended solids will be collected using ISCO automated samplers set to collect samples at 5-minute intervals during storm events. Particle-size distribution analyses will be conducted on the runoff samples.

PROGRESS (July 1999 to June 2000): An initial fact sheet on solids loading from construction sites without Best Management Practices (BMP) was completed in June 1999. Instrumentation was installed at a new site for the construction site BMP evaluation in May 1999. Equipment needed to be moved to new BMP evaluation site in March 2000.

PLANS (July 2000 to December 2000): Data and waterquality samples at the BMP evaluation site will be collected until July 2000. A second fact sheet will be written detailing the results of the "standard" and "advanced" BMP evaluation. 


\section{EVALUATION OF THE EFFECTIVENESS OF URBAN CONSERVATION DESIGN PRACTICES, WI 17233}

PROBLEM: Farmland in Wisconsin is rapidly being converted to urban land uses. This urban development, with the associated increase in impervious area, generally impacts the water quality and increases the runoff volume that is delivered to the receiving waterbody. When new site plans are proposed, many of the plans use "end-of-pipe" structural Best Management Practices (BMPs) such as wet and dry detention ponds. These structural BMPs, however, are primarily designed to reduce the flood peak of a runoff event. They have limited water-quality and -quantity benefits.

A non-structural type of BMP called urban stormwater-conservation design is being developed for urban land uses. This BMP involves reducing stormwater-runoff quantity and improving the stormwaterrunoff quality. These conservation designs include the reduction of impervious surfaces, redirection of downspouts to grassed areas, using grass infiltration swales and rain gardens to infiltrate runoff, and using cluster developments to encourage smaller lot sizes.

OBJECTIVE: The objective is to evaluate the effectiveness of urban conservation design for reducing runoff quantity and improving runoff water quality.

APPROACH: Two separate sites have been selected in Cross Plains, Wisconsin. The first site, which was developed from 1988 to 1991, used traditional urban design practices such as storm sewers, curbs and gutters, and a wet detention basin. The second site, currently a farm field, will be developed in May 1999 using urban stormwater-conservation design practices. Both sites are finger valleys that are approximately a quarter mile apart.

Equipment at both sites will be installed and maintained to continuously monitor water level, precipitation, and water temperature. An automatic water-quality sampler will be installed at each site to take flow proportional samples. Water-quality samples for the majority of the runoff events will be analyzed for total and suspended solids, and total phosphorus. Periodically, samples from each site will be processed for particle-size distribution and selected total metals. All equipment at each site will be installed in a gaging station that will have phone telemetry and electrical power.

Comparisons will be made between the BMPs based on unit-area runoff and unit-area loads. Furthermore, the data collected during the seven-year period will document the changes in water quality and quantity during the construction cycle (from platting to site closeout).

PROGRESS (July 1999 to June 2000): Both sites were monitored during the subdivision platting phase and initial home construction was monitored at the rural site. A digital camera was installed to photo document construction activities. These photos are displayed on the USGS web site.

PLANS (July 2000 to June 2001): Monitoring at both sites will continue. Additional monitoring equipment will be installed at the three pond inlets, the pond outlet and in the infiltration practice. Solids loads will be computed for all monitored runoff events at both sites.
COOPERATOR:

Wisconsin Department of

Natural Resources

LOCATION:

Cross Plains

PROJECT CHIEF:

David W. Owens

PERIOD OF PROJECT: July 1998 to September 2005

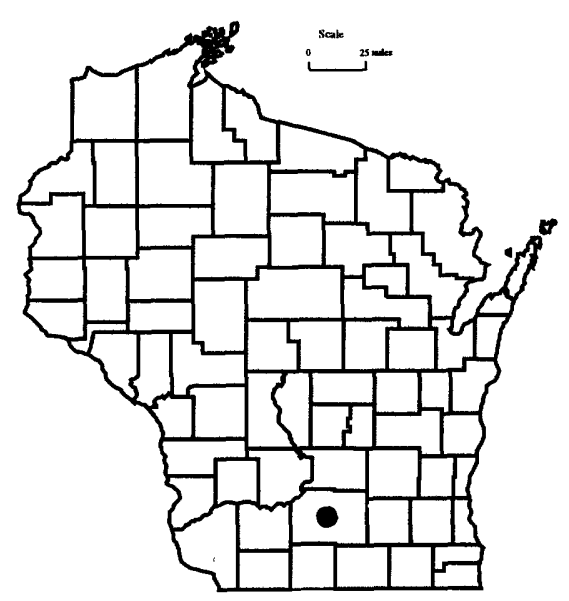




\section{TEMPERATURE MODELING OF URBAN STORMWATER RUNOFF, WI 17234}

COOPERATOR:

Wisconsin Department of Natural Resources

\section{LOCATION:}

Cross Plains

PROJECT CHIEF:

David W. Owens

PERIOD OF PROJECT: July 1998 to September 2000
PROBLEM: Rainwater that falls on urban surfaces during the warm summer months tends to collect heat from those urban surfaces. The heated rainwater tends to drain quickly to storm sewers and then into streams or lakes. When the receiving water body is a cold water fishery, the thermal load can have a detrimental effect.

OBJECTIVE: The objective is to develop a model that can estimate the thermal heating of rainwater from urban surfaces during the summer months.

APPROACH: Sensors will be installed to monitor surface temperatures at a wide variety of thermal source areas in a drainage basin in Cross Plains, Wisconsin. These thermal source areas include roofs, streets, driveways and lawns. Furthermore, a variety of source area materials (asphalt, concrete, metal, etc.) and colors (light and dark) will also be monitored. The continuously collected data will document the changes in surface temperature and in the runoff water as the runoff water moves through the conveyance system. The data collected will be used to develop a model that will estimate the thermal impact of different urban surfaces.

PROGRESS (July 1999 to June 2000): Several sensors were installed and modified throughout the basin. Intensive data collection started in early June 1999 and continued until the end of September 1999. During this monitoring period, a worst-case thermal loading event did not occur. The equipment was activated in May 2000 to attempt to capture the worst-case thermal event. A water temperature model was developed to predict thermal loads to a coldwater-receiving stream based on the data collected during the summer of 1999 and 2000.

PLANS (July 2000 to September 2000): Additional temperature data will be collected until August 2000. New data collected will be used to calibrate the thermal runoff model. Model documentation will be completed during this time frame.

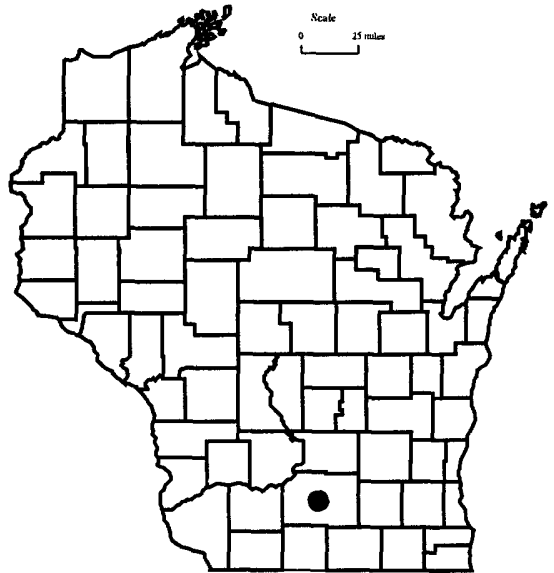




\section{IMPACTS OF RESIDENTAL CONSTRUCTION ON STREAM WATER QUALITY, WI 17235}

PROBLEM: Population in Dane County, Wisconsin, is growing at a fast pace. Farmland is being taken out of crop production and being replaced with urban land uses. During this urbanization, large tracts of land are being disturbed to create new subdivisions for residential housing. This disturbance can have a large impact on water quality and quantity as well as in-stream impacts such as sedimentation and higher temperature. Quantification of these changes needs to be documented to reduce future in-stream impacts.

OBJECTIVE: The main objective of this project is to determine the "in-stream" impacts of residential urbanization on a small stream in Cross Plains, Wisconsin. Additional objectives include (1) comparing the sediment load estimated by the Universal Soil Loss Equation (USLE) and the Revised Universal Soil Loss Equation (RUSLE) to monitored data and (2) determining the changes in hydrology of the site by quantifying variation in peak flows as related to changes in drainage basin surface characteristics caused by the construction activities.

\begin{abstract}
APPROACH: Discharge, and associated solids and phosphorus concentrations and loads will be measured both upstream and downstream of a 40-acre site that will be converted from agricultural to residential land use. Water-quantity, water-quality, and land-use data will be collected at a site located immediately upstream of the residential development and at an existing USGS gaging station (Brewery Creek at Cross Plains, 05406470) located immediately downstream of the development. Monitoring will be done prior to construction, during construction, and after construction. Waterquality analyses include total suspended solids, total phosphorus, and particle-size distribution. Before and after event mean concentrations from the upstream and downstream sites will be statistically compared.
\end{abstract}

PROGRESS (July 1999 to June 2000): Monitoring and photo documentation were continued during the pre-construction phase of the project.

PLANS (July 2000 to June 2001): Monitoring and photo documentation activities will be intensified during the construction phase of the project.
COOPERATOR:

Dane County Land Conservation Department

\section{LOCATION:}

Cross Plains

PROJECT CHIEF:

David W. Owens

PERIOD OF PROJECT:

April 1999 to September 2002

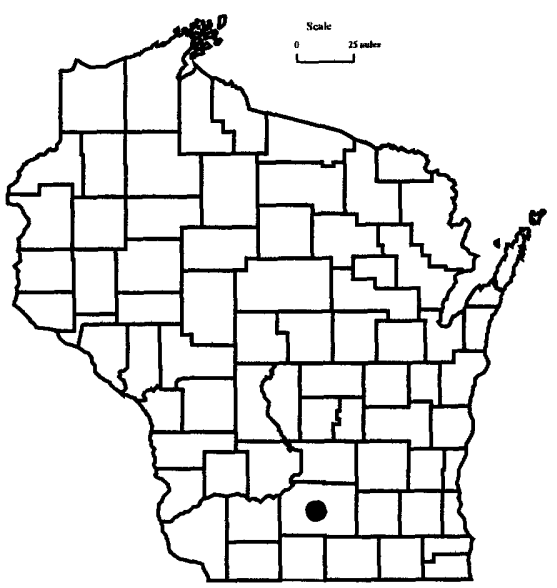




\section{ROCK RIVER PHOSPHORUS, WI 17236}

COOPERATORS:

City of Fort Atkinson

Rock River Watershed Publicly-

Owned Treatment Works (66.30)

Group

Wisconsin Department of Natural Resources

\section{LOCATION:}

Rock River Basin

PROJECT CHIEF:

William R. Krug

PERIOD OF PROJECT: July 1998 to September 2000

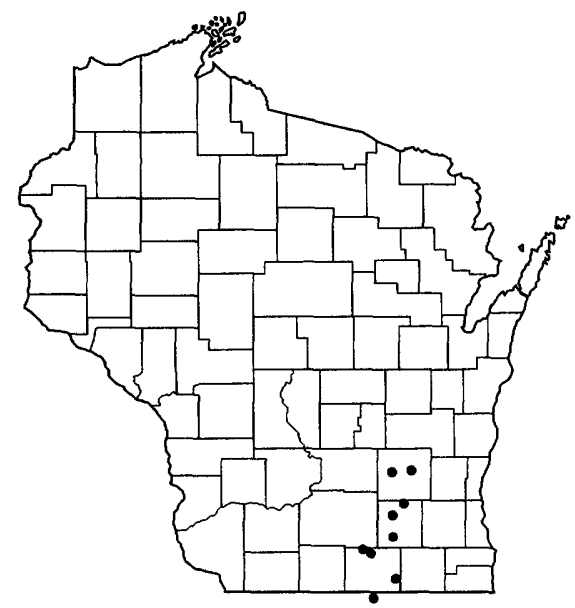

PROBLEM: Water quality of the Rock River depends on the load of nutrients contributed to the river by various sources. Sound management of water quality requires knowledge of the contributions of various sources to the total load of the river.

OBJECTIVE: The objective is to determine concentrations of various water-quality constituents at nine sites in the Rock River Basin in Wisconsin and to calculate loads for dissolved reactive phosphorus, total phosphorus and suspended solids

APPROACH: Water-quality samples will be collected by staff of the cooperating treatment works twice each month, and at additional times when there is significant runoff. These data will be used to compute loads of the following constituents until August 1999:

5-day Biological Oxygen Demand

Dissolved Chloride

Chlorophyll $a$

Fecal Coliform

Dissolved Ammonia

Nitrate + Nitrite

Dissolved Reactive Phosphorus

Total Dissolved Solids

Total Kjeldahl Nitrogen

Total Phosphorus

Suspended Solids

Volatile Suspended Solids

Data will be used to compute loads for the following constituents from September 1999 to August 2000:

5-day Biological Oxygen Demand

Nitrate + Nitrite

Total Phosphorus

Dissolved Reactive Phosphorus

Suspended Solids

Volatile Suspended Solids

PROGRESS (July 1999 to June 2000): Water-quality samples were collected and analyzed twice each month, with additional samples during significant runoff. Loads for three constituents were calculated for the period August 1998 through September 1999, and published in the annual data report. Sampling was continued for a second year, with the shortened list of constituents.

PLANS (July 2000 to September 2000): When a second full year of data has been collected (by the end of August 2000), the data will be used to compute loads of phosphorus and sediment.These will be published in the annual data report. A brief final report will be prepared explaining the data-collection procedures and summarizing the loads computed. 


\section{ASSESSMENT OF THE HYDROLOGY AND WATER QUALITY OF, AND PHOSPHORUS LOADING TO, PIKE LAKE IN WASHINGTON COUNTY, WI 17301}

PROBLEM: The following are issues of concern: near-bottom phosphorus concentrations in the lake appear to be increasing over time, indicating possible increasing phosphorus release from lake sediments; trophic state of the lake is borderline mesotrophiceutrophic and information on various phosphorus loading sources and rates are not available to evaluate potential changes in lake condition under present, increased, or decreased loading scenarios; the effects of increasing development in the watershed and resulting increasing storm runoff and discharge from waste-water treatment plants into the Rubicon River are unknown; the effectiveness of the present partial inlet diversion or short-circuiting of inflow to the outlet is unknown; and the potential for additional phosphorus load reduction to the lake with enhanced diversion is unknown.

OBJECTIVE: Objectives are to define the hydrology and water budget of the lake, determine the phosphorus loads from various sources and develop a phosphorus budget for the lake, assess the effectiveness of the inlet diversion and potential for improved diversion, and evaluate the effects of increases or decreases in phosphorus loading on the trophic status of the lake.

APPROACH: The study will consist of gage installation and two years of data collection followed by data analysis and report preparation. Data collection will be done from December 1998 through October 2000. Flow and water-quality data will be collected at the Rubicon River inlet to, and outlet from, the lake and at selected other inflows. These data will be used to describe the hydrology and water budget of the lake, calculate an annual phosphorus budget for the lake and evaluate effects of loading changes on the lake's trophic status. In-lake water-quality data will be provided by the Wisconsin Department of Natural Resources.

PROGRESS (July 1999 to June 2000): Streamflow and water-quality monitoring continued. Numerous flow measurements were made to compensate for poor performance of the velocity meter at the inlet site. Preliminary water and phosphorus budgets were computed for the first year of data collection. The Rubicon River was the dominant source of phosphorus entering the lake. However, much of that phosphorus (about 70 percent) got "short circuited" to the lake's outlet. A data summary and progress report were prepared for the lake district.

PLANS (July 2000 to June 2001): Monitoring at the lake's inlet and outlet will continue. A doppler velocity meter will be installed at the inlet site to replace the acoustic meter. Small-diameter piezometers will be installed near shore around the lake to determine ground-water gradients. A data summary and the final report will be prepared for the lake district. Data will be published in the annual report "Water Resources Data-Wisconsin".
COOPERATOR:

Pike Lake Management District

LOCATION:

Southwestern Washington

County

PROJECT CHIEF:

William J. Rose

PERIOD OF PROJECT:

October 1998 to December 2001

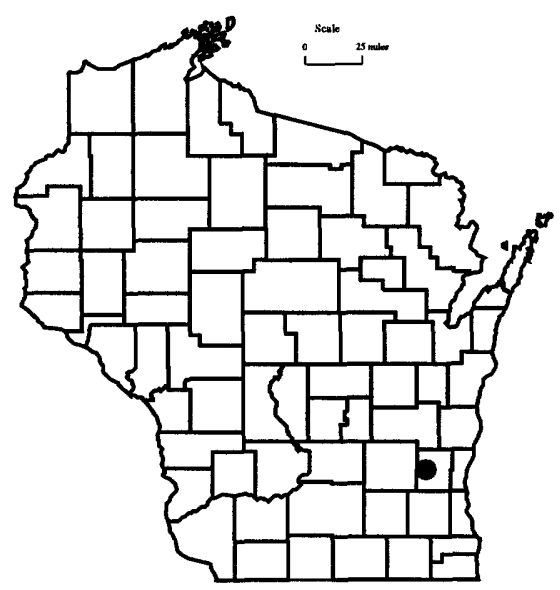




\section{MISCELLANEOUS MONITORING ASSOCIATED WITH LAKES, WI 17302}

COOPERATOR:

City of Muskego

Little Muskego Lake Management District

Whitewater Rice Lakes

Management District

Wind Lake Management District

\section{LOCATION:}

Statewide

PROJECT CHIEF:

William J. Rose

PERIOD OF PROJECT:

October 1998-Continuing
PROBLEM: Monitoring miscellaneous, single hydrologic aspects of lakes is needed, but does not warrant establishing separate projects or subprojects. This monitoring is typically narrow in scope, such as flow or loading from a single lake tributary or lake stage, and is usually a prelude to, or follow-up from, a more comprehensive lake study.

OBJECTIVE: The objective is to collect lake stage, streamflow, stream-water quality, and constituent load data as needed. These lake-related monitoring efforts will be managed and financially tracked in this subproject of WI 17300.

APPROACH: Monitoring that fits into this subproject will be done using appropriate standard USGS practices. A streamflowgaging station will be operated and loads of Jewel Creek, a tributary of Little Muskego Lake in Waukesha County, will be monitored.

PROGRESS (July 1999 to June 2000): Monitoring of flow, phosphorus loading, and suspended-sediment loading to Little Muskego Lake at the mouth of Jewel Creek continued. Monitoring of flow, sediment and phosphorus from Big Muskego Lake continued.

PLANS (July 2000 to June 2001): Monitoring at last year's sites will continue. Data will be published in the annual report "Water Resources Data-Wisconsin".

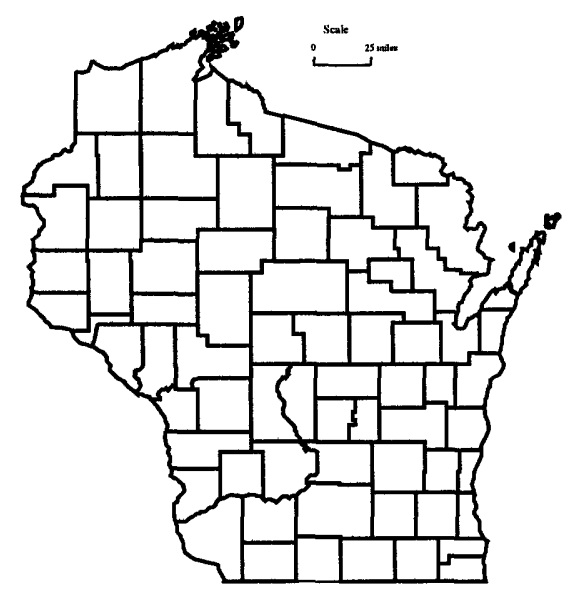




\section{WISCONSIN LAKES, GREEN LAKE TRIBUTARY MONITORING WI 17303}

PROBLEM: Silver Creek is the primary source of phosphorus to Green Lake. Continued documentation of suspended sediment and phosphorus loads from major tributaries helps to explain the lake's water quality. Data are needed to determine changes in loads over time and loading variability in relation to streamflow.

OBJECTIVE: The objectives of this project are to determine suspended sediment and phosphorus loads in relation to streamflow in selected tributaries to Green Lake.

APPROACH: Streamflow will be monitored continuously at selected sites. Water-sediment samples will be collected manually and by automatic samplers during storm runoff. Suspendedsediment and nutrient concentrations will be determined. Daily, monthly, and annual mean suspended-sediment and nutrient loads will be computed.

PROGRESS (July 1999 to June 2000): Streamflow and water quality were monitored at the Silver Creek inlet to Green Lake and at the mouth of White Creek. The Silver Creek site is equipped with an acoustic velocity meter, a stage gage, and an automatic water sampler. The White Creek site is a conventional stream-gaging site and is equipped with an automatic water sampler. Streamflow, phosphorus, and suspended-sediment loading to the lake were determined for both sites.

A gage on the Puchyan River near the outlet of Green Lake was operated to monitor flow from the lake. Water samples were collected manually for phosphorus analysis. Streamflow, load and concentration data were published in the report "Water Resources DataWisconsin".

PLANS (July 2000 to June 2001): Streamflow and waterquality monitoring at the Silver Creek and White Creek inlets and at the Puchyan River outlet will be continued. Streamflow, phosphorus, and suspended-sediment loads will be published in the annual report, "Water Resources Data-Wisconsin".
COOPERATOR:

Green Lake Sanitary District

LOCATION:

Green Lake County

PROJECT CHIEF:

William J. Rose

PERIOD OF PROJECT:

October 1977-Continuing

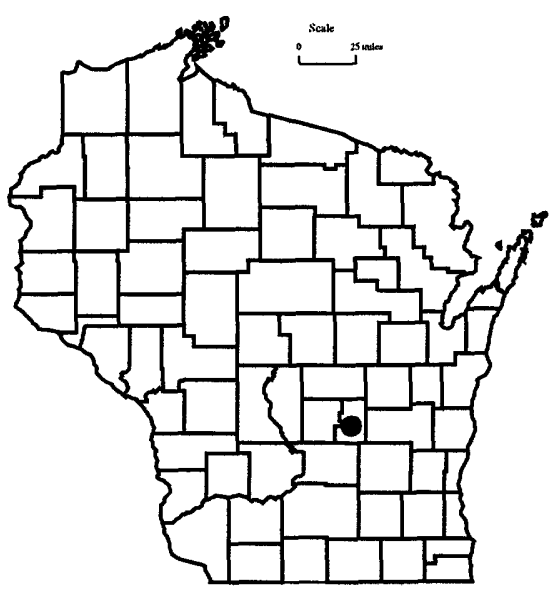




\section{POOL 8 GROUND-WATER/SURFACE-WATER STUDY, WI 17304}

COOPERATOR:

U.S. Geological Survey, Water Resources Division, National Stream Quality Accounting Network Program

\section{LOCATION:}

Southwestern Wisconsin

PROJECT CHIEF:

Randy J. Hunt

PERIOD OF PROJECT: May 1999 to September 2001
PROBLEM: Nitrogen loading and transformation in the Upper Mississippi River (UMR) system has recently become an issue of concern. The influence of ground water on the loading and transformation is poorly known, primarily due to the difficulty in quantifying the location and magnitude of ground-water/surface-water interaction and lack of knowledge regarding nitrogen concentrations contained within the ground water. The interactions of ground water and surface water, however, may influence the occurrence and rates of nitrate reactions in the Upper Mississippi River system.

OBJECTIVE: The project objectives are to (1) determine magnitude of ground-water discharge and nitrate loading via ground water to the Pool, and (2) delineate important contributing areas for the Pool.

APPROACH: The investigation is conducted using a stepwise approach where a model will initially be developed using existing data. Results of the initial model are then used to guide future data collection, which is used to update the model. The initial groundwater-flow model will be constructed using analytic element methods. Different system conceptualizations will be tested by coupling the analytic element model to a parameter estimation code. The field work will include on-shore installation of permanent well nests to characterize the local and regional ground-water systems, installation of temporary well nests within Pool 8, installation of thermocouple strings in areas of suspected high ground-water discharge rates to measure ground-water-flow velocities, and collection of ground-water samples for nutrient analyses and age dating. After the field work phase, the analytic element model will be updated and refined. The analytic element model will then be translated to a three-dimensional model using the finite-difference code MODFLOW. The resulting three-dimensional model and geochemical sampling will be used to construct maps of groundwater discharge, flowpaths, travel times, and ground-water quality.

PROGRESS (July 1999 to June 2000): An analytic element ground-water-flow model of the regional system has been constructed. The model was calibrated using existing head and flux data from the area. Five piezometer nests extending from Onalaska to Genoa were installed and instrumented with continuous water level recorders.

PLANS (July 2000 to June 2001): A synoptic survey of Pool 8 shallow ground water will be conducted to assess distribution of nitrate and vertical gradients. The analytic element model will be refined using field data. 


\section{HYDROLOGIC INVESTIGATION OF SILVER LAKE, WI 17305}

PROBLEM: An increased understanding of the hydrologic budget components of Silver Lake will help in developing a tool (waterbudget model) to test the understanding of the system and model the ground-water/surface-water interaction within the lake basin. This model will used by the District as a tool in lake management decisions.

OBJECTIVES: Specific objectives are to (1) determine the hydraulic parameters and budget components of Silver Lake, (2) quantify the loading to the lake due to ground-water inflow, and (3) identify key ground-water recharge areas for Silver Lake.

APPROACH: Historical data will be used to develop a numerical ground-water-flow model of Silver Lake and its watershed. Water budget parameters to be included in the model are precipitation, evaporation, and measured water levels and flows. This model will be calibrated to lake stage and discharge. Based on previous models of this type, the hydraulic conductivity of the lake bed and runoff coefficients are the most likely parameters to be adjusted during the calibration process.

PROGRESS (October 1999 to June 2000): Initial meetings have been held with the cooperator to discuss the objectives and timetable for the hydrologic investigation. Work is expected to begin summer of 2000 .

PLANS (July 2000 to June 2001): Historical data will be gathered and used to develop a numerical ground-water-flow model of Silver Lake and its watershed. Water budget parameters such as precipitation, evaporation, and measured water levels and flows will be defined. Some field activities will begin summer of 2000 .
COOPERATOR:

Silver Lake Protection and Rehabilitation District

\section{LOCATION:}

Washington County

PROJECT CHIEF:

Charles Dunning

PERIOD OF PROJECT:

October 1999 to September 2001

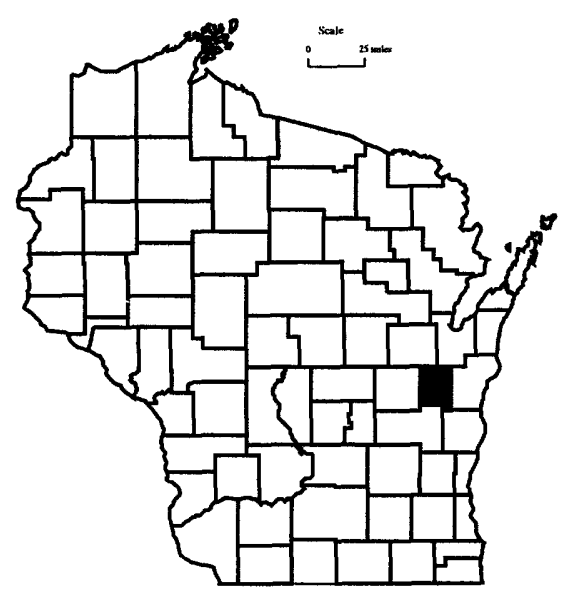




\section{FISH LAKE, DANE COUNTY, WI 17306}

\section{COOPERATOR:}

\section{Dane County Lakes and \\ Watershed Management}

\section{LOCATION:}

Northwestern Dane County

\section{PROJECT CHIEF:}

Jim Krohelski

PERIOD OF PROJECT: January 2000 to September 2001
PROBLEM: There has been a steady increase in the stage of Fish Lake over the last 25 years. The lake, located in northwestern Dane County, Wisconsin, is a 216-acre seepage lake having a maximum depth of 62 feet. The Fish Lake Association is concerned over the flooding of roads and near-shore residences caused by high lake stages. The Association has contemplated withdrawing lake water during high stage periods but a better understanding of the hydrology of the lake/ground-water system and the long-term effect of withdrawing lake water on lake stage are required before decisions can be made.

Estimates of the hydrologic budget components and hydraulic parameters (e.g., hydraulic conductivity and gradient and runoff and evaporation coefficients) of Fish Lake are essential in developing a tool (water-budget model) to predict the effects of withdrawing lake water on future lake stages. The model, when calibrated, will help answer the following questions: (1) will pumping at high stage affect future low stage; (2) would diversion of surface sources significantly reduce stage; and (3) how much pumping is needed?

OBJECTIVE: The objectives are to (1) demonstrate an understanding of the hydrology of Fish Lake by simulating lake stage using estimated hydrologic budget components and hydraulic parameters and (2) predict the possible effect of pumping water from Fish Lake on future lake stage.

APPROACH: A model that calculates lake stage due to variations in budget components or withdrawal of lake water will be developed. Historical data will be used to develop a water-budget model. This model will be calibrated to lake stage. The calibrated model will be used to predict the possible effect of pumping water from Fish Lake on future lake stage.

PROGRESS (January 2000 to June 2000): Historical precipitation and evaporation data were compiled. Equipment for monitoring shallow ground-water levels adjacent to the lake was obtained.

PLANS (July 2000 to June 2001): A model that calculates lake stage due to variations in budget components or withdrawal of lake water will be developed. 


\section{CRYSTAL LAKE, DANE COUNTY, WI 17307}

PROBLEM: Crystal Lake is a 500-acre seepage lake with a maximum depth of 9 feet and is located about 1/4 mile east of Fish Lake in Dane County. The Fish Lake Association has contemplated withdrawing lake water to mitigate flooding of roads and several nearby residences. Crystal Lake is probably hydraulically connected to the same shallow ground-water-flow system as Fish Lake. If withdrawing water from Fish Lake lowers the water table in the vicinity of Fish Lake, it may also cause an unwanted lowering of Crystal Lake stage.

OBJECTIVE: The objectives are to (1) demonstrate an understanding of the hydrology of the lake/ground-water system in the vicinity of Crystal, Fish and Mud Lakes by simulating measured lake stage, ground-water elevation and local streamflow and (2) predict the possible effect of pumping water from Fish Lake on Crystal Lake stage.

APPROACH: A review of existing data that includes published reports and papers, available driller's construction reports and geological logs and unpublished data from other agencies such as the Wisconsin Geological and Natural History Survey will be conducted during the first few months of the study. These data will be used to determine the hydrogeologic framework and hydraulic parameters for model development. From this framework, a conceptual model of the interaction between the lakes and the ground-water system will be formulated. A numerical model of the lake(s) ground-water system will be used to test the validity of the conceptual model. Calibration of the ground-water-flow model will be obtained by comparison of previous ground-water gradient values and head and streamflow measurements to simulated values. After calibration, the model will be used in predictive mode to determine the effect of pumping or diversion from Fish Lake on Crystal Lake stage.

PROGRESS (January 2000 to June 2000): Historical precipitation and evaporation data were compiled. Equipment for monitoring shallow ground-water levels adjacent to the lake was obtained.

PLANS (July 2000 to June 2001): A model that calculates lake stage due to variations in budget components or withdrawal of lake water will be developed.
COOPERATOR:

Dane County Lakes and

Watershed Management

\section{LOCATION:}

Northwestern Dane County

PROJECT CHIEF:

Jim Krohelski

PERIOD OF PROJECT:

January 2000 to September 2001

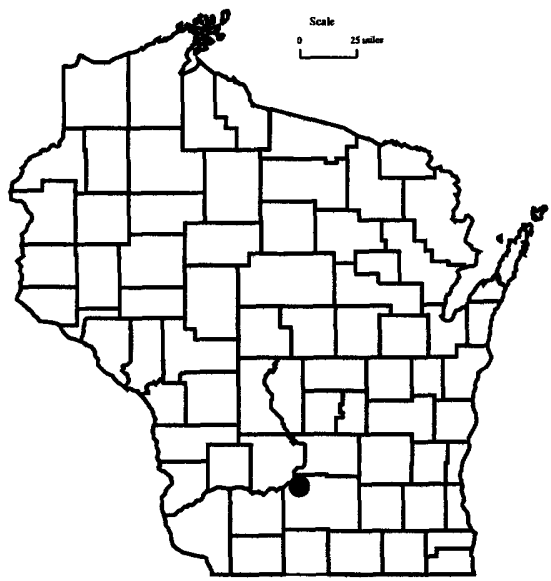




\section{LAUDERDALE LAKES RESTORATION MONITORING, WI 17310}

\section{COOPERATOR:}

\author{
Lauderdale Lakes Lake \\ Management District
}

\section{LOCATION: \\ Walworth County}

PROJECT CHIEF:

Herbert S. Garn

PERIOD OF PROJECT:

October 1998 to September 2002
PROBLEM: The Lauderdale Lakes Lake Management District is implementing actions and practices designed to reduce nutrient loading to the lakes from agricultural and near-shore residential sources. Actions include wetland restoration and enhancement, stormwater management practices, and lawn fertilization practices to demonstrate the feasibility of applying such techniques for protecting or improving the water quality of lakes in southeastern Wisconsin. The effectiveness of these practices is not known and needs to be determined.

OBJECTIVE: The objective is to conduct water monitoring needed to assess the results and effectiveness of selected practices being implemented to reduce phosphorus loading to these lakes.

APPROACH: Several types of monitoring will be conducted and will be used to evaluate the effectiveness of practices to be installed around the lakes to improve runoff water quality. Watermonitoring efforts include: (1) monitoring continuous discharge, total phosphorus and solids loads from an ephemeral tributary to Green Lake that will be receiving treatments to improve runoff quality, (2) monitoring in-lake water quality of Middle Lake to describe and quantify lake water quality during the restoration period, and (3) monitoring surface runoff from representative lawns around Lauderdale Lakes and determining the effect of various lawn fertilizing practices on phosphorus content of lawn runoff. Highly fertilized lawns, use of non-phosphorus fertilizer, and no fertilizer applications are the practices that will be evaluated.

PROGRESS (July 1999 to June 2000): Lawn runoff monitoring was conducted at 12 sites during the growing season to determine phosphorus content and a continuous-recording gaging station with automatic water sampler was operated on an ephemeral stream on the northeast side of Green Lake. Four additional lawn runoff plots were installed. Lake water-quality monitoring was conducted on Middle Lake. Total phosphorus concentrations of lawn runoff samples were measured as high as $20 \mathrm{mg} / \mathrm{L}$. No flow occurred in the tributary during the season. Data were reviewed and published in the annual data report for water year 1999.

PLANS (July 2000 to June 2001): Lake sampling and runoff monitoring of the lawn and stream sites will be continued. Final records and loads will be computed for the water year. Data collected during the water year will be prepared for publication in the annual data report "Water Resources Data-Wisconsin". Lawn runoff data will be summarized and a draft of a fact sheet will be prepared. 


\section{ASSESSMENT OF PHOSPHORUS LOADING, WINTER ANOXIA, AND STAGE REGULATION OF LITTLE ST. GERMAIN LAKE, VILAS COUNTY, WI 17313}

PROBLEM: Little St. Germain Lake consists of three main basins (East Bay, South Bay, and West Bay) separated by narrows. Muskellunge Creek, the lake's only inlet stream, enters East Bay. A dam at the lake's outlet is used to regulate lake stage and flow from South Bay. Hence, the net flow of water is from East Bay to South Bay. Summer water quality ranges from good to very good in the West Bay, fair to good in the South Bay, and poor to very poor in the East Bay, based on monitoring from 1992-1994. Dissolved oxygen was absent at the South Bay monitoring site in late winter each year from 1992-1994. The areal extent and cause of the oxygen problem is not known. There is concern that the annual range of stage regulation (about 1.5 feet) has an adverse effect on lake water quality and possibly introduces nutrient to the West Bay.

OBJECTIVE: The primary objectives of the study are to (1) estimate the annual total-phosphorus loading from Muskellunge Creek and adjacent watershed area, (2) determine the extent of the dissolved-oxygen problem throughout the lake, (3) monitor waterquality trends in all three basins, and (4) estimate annual totalphosphorus loading to West Bay caused by current lake stage regulation policy.

APPROACH: Flow in Muskellunge Creek will be measured and sampled intermittently (about monthly). Samples will be analyzed for concentration of total phosphorus. The data will be used to calculate the water and phosphorus loading to the East Bay. Extent of anoxia throughout the lake will be determined by measuring dissolved-oxygen profiles in late winter. The amount of water moving from East Bay into West Bay during the stage recovery period following winter drawdown will be calculated and used, along with phosphorus concentration data, to estimate phosphorus loading to the West Bay.

PROGRESS (July 1999 to June 2000): Data monitoring continued as scheduled. A draft report for the completed phase of the project was written.

PLANS (July 2000 to June 2001): Findings from past and current phases of the study will be published in a USGS Fact Sheet. A future phase of the study will evaluate effects of management practices to be implemented by the lake district.
COOPERATOR:

Little St. Germain Lake District

LOCATION:

10 miles west of Eagle River

PROJECT CHIEF:

William J. Rose

Dale M. Robertson

PERIOD OF PROJECT: August 1996 to June 2001

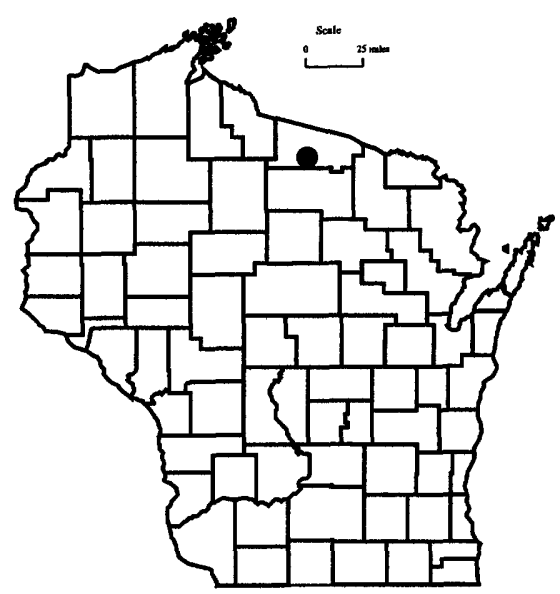




\section{ASSESSMENT OF THE WATER QUALITY, HYDROLOGY, AND BIOLOGY OF GENEVA LAKE, WI 17314}

\author{
COOPERATOR: \\ Geneva Lake Environmental \\ Agency
}

\section{LOCATION:}

Walworth County

PROJECT CHIEF:

Dale M. Robertson

William J. Rose

PERIOD OF PROJECT: March 1997 to September 2001

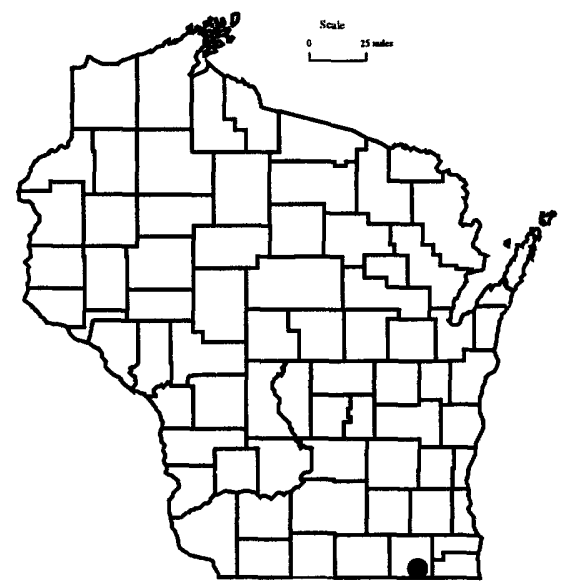

PROBLEM: Because of increased urban development and recreational use, concerns have arisen over the potential decline in the water quality of Geneva Lake. The public perception is that the water quality of Geneva Lake is declining; however, little direct evidence is available to support or deny the perceptions. To reduce the impact on the lake, efforts are being made to decrease the point and nonpoint-source pollution to the lake. However, more water-quality and biological information are needed to determine which pollution prevention strategies will be most cost effective.

OBJECTIVE: The objectives of this project are to (1) document the water quality and planktonic populations in the lake, (2) estimate phosphorus and sediment loading to the lake, (3) determine the historical water quality of the lake by examining lake sediments, and (4) construct hydrologic and phosphorus budgets for the lake.

APPROACH: Phosphorus and streamflow were monitored at two locations upstream of Geneva Lake and at the outlet from which loads of phosphorus to and from the lake were estimated. Nutrient concentrations, dissolved oxygen, water temperature, $\mathrm{pH}$, specific conductance, and phytoplankton and zooplankton populations were monitored at different frequencies and different locations to determine the "best" frequency and locations to describe changes in water quality in the lake. Nutrient and phosphorus budgets will be constructed for the lake using a dynamic simulation model. Sediment cores will be analyzed to estimate sedimentation rates and the historical water quality of the lake.

PROGRESS (July 1999 to June 2000): Lake sampling at two locations was done monthly for field parameters and nutrients. Gaging stations were operated on two tributaries to the lake and at the outlet for streamflow, total phosphorus, and suspended sediment concentrations until September 1999 and loading to the lake was estimated. A preliminary dynamic model was configured for the lake. Surface lake-bed sediment data were analyzed for various contaminants. One sediment core was examined for sediment deposition rates and long-term changes in the water quality of the lake.

PLANS (July 2000 to June 2001): Monthly lake sampling will continue throughout the period at the deep hole in the West Bay. Streamflow will be estimated for one inlet and the outlet. Water and phosphorus budgets will be constructed for the lake. Lake sediment data will be published as a fact sheet. Sediment core analyses will be completed. The dynamic model will be fully developed for the lake and used to construct nutrient budgets and examine long-term changes in water quality. 


\section{DETERMINATION OF STREAMFLOW, PHOSPHORUS, AND SOLIDS LOADS AT THREE SITES ABOVE SINISSIPPI LAKE IN DODGE COUNTY, WI 17317}

PROBLEM: Sinissippi Lake was formed in 1845 by construction of a dam on the Rock River south of Horicon Marsh. The watershed area for the shallow (average depth $4.5 \mathrm{ft}$.) 2,855acre lake is about 511 square miles. The lake is hypereutrophic with phosphorus concentrations ranging from 200 to 400 micrograms per liter. Secchi depths during summer average about 0.2 meters. Local, state, and federal resource agencies are concerned with the quality of the Horicon Marsh area, including Sinissippi Lake. Basic data are lacking to define the sources and magnitude of streamflow, phosphorus, and solids entering Sinissippi Lake.

OBJECTIVE: The primary objective of the study is to determine streamflow, phosphorus, and suspended-solids loading at East Branch Rock River near Mayville, West Branch Rock River near Waupun, and Rock River at Horicon and Hustisford.

APPROACH: Streamflow, phosphorus and suspended-solids load monitoring will be done at East Branch Rock River near Mayville, West Branch Rock River near Waupun, and Rock River at Horicon and Hustisford. Stream gages, employing conventional stage-discharge rating techniques, and equipped with automatic water samplers will be installed at East Branch Rock River near Mayville and West Branch Rock River near Waupun. The Rock River at Horicon site will be equipped with an acoustic velocity meter (AVM) gage because flat gradients preclude conventional gaging there. Samples will be collected manually by a local observer at the Horicon site. Loads will be calculated using streamflow-concentration-integration techniques.

PROGRESS (July 1999 to June 2000): Monitoring sites were operated through the 1999 water year and continued into the 2000 water year. Annual total-phosphorus load at the West Branch Rock River was 111,400 lb; at the East Branch Rock River, it was $90,700 \mathrm{lb}$; at the Rock River at Horicon the load was 318,100 lb, and at the Rock River at Hustisford for the period December 1, 1998 to September 30, 1999, the load was $276,300 \mathrm{lb}$. Suspendedsolids loads were 4,460 tons at the West Branch Rock River, 5,280 tons at the East Branch Rock River, 25,900 tons at the Rock River at Horicon and 23,230 tons at the Rock River at Hustisford for the period of December 1, 1998 to September 30, 1999. All streamflow and water-quality data were summarized and published in the annual report "Water Resources Data-Wisconsin, 1999".

PLANS (July 2000 to June 2001): Monitoring of the sites will continue through the 2000 water year. Daily streamflow and total-phosphorus and suspended-solids loads will be calculated. Data will be published in the annual report "Water Resources DataWisconsin, 2000".
COOPERATOR:

Town of Hubbard

LOCATION:

Central Dodge County

PROJECT CHIEF:

David J. Graczyk

PERIOD OF PROJECT:

October 1997 to September 2001

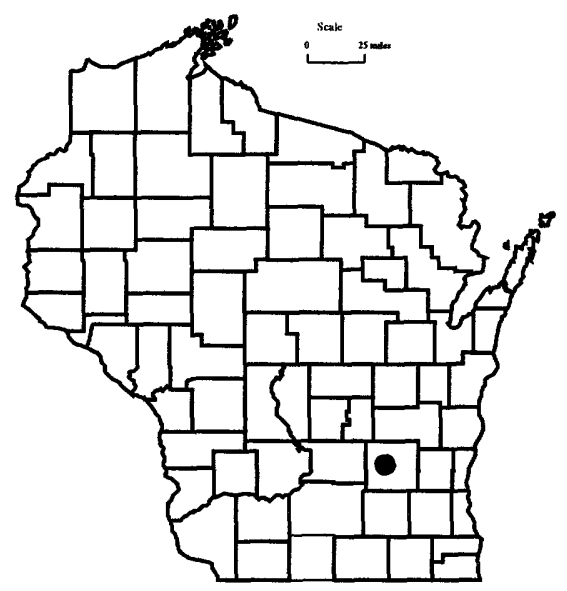




\section{MIDDLE GENESEE LAKE GROUND-WATER STUDY, WI 17319}

\section{COOPERATOR:}

Middle Genesee Lake District

\section{LOCATION:}

Waukesha County

PROJECT CHIEF:

Randy J. Hunt

PERIOD OF PROJECT:

January 1999 to September 2000
PROBLEM: Middle Genesee Lake is a 109-acre seepage lake that has had significant variations in water levels and quality over the years. Climate and ground water are thought to be among the primary drivers for these variations. The Middle Genesee Lake District desires to have a scientifically based tool that can be used to understand the hydrology of the lake, and to protect it from future threats to water quantity and quality.

OBJECTIVE: The project objectives are to (1) identify key ground-water recharge areas for the lake, (2) quantify ground-water flow into the lake, and (3) determine important hydraulic parameters for ground- and surface-water interaction.

APPROACH: New and existing data for the site area will be used to construct a numerical ground-water-flow model that incorporates water-budget parameters. Water budget data include parameters such as precipitation, evaporation, ground-water levels, lake stage, and channel flows. The model will be calibrated to lake stage and channel discharge. Recharge areas will be delineated using numerical particle tracking.

PROGRESS (July 1999 to June 2000): An analytic element ground-water-flow model of the lake vicinity has been completed. The model was calibrated using existing head and flux data from the area. Quantitative estimates of effects caused by changes in the lake's watershed were also performed. A water-resources investigations report describing the model construction and results has been written and is in review.

PLANS: Project is complete.

\section{REPORT:}

Hunt, R.J., Lin, Y., Krohelski, J.T., and Juckem, P.F., Simulation of the shallow ground-water flow system in the vicinity of Middle Genesee Lake, Waukesha County, Wisconsin (in review).

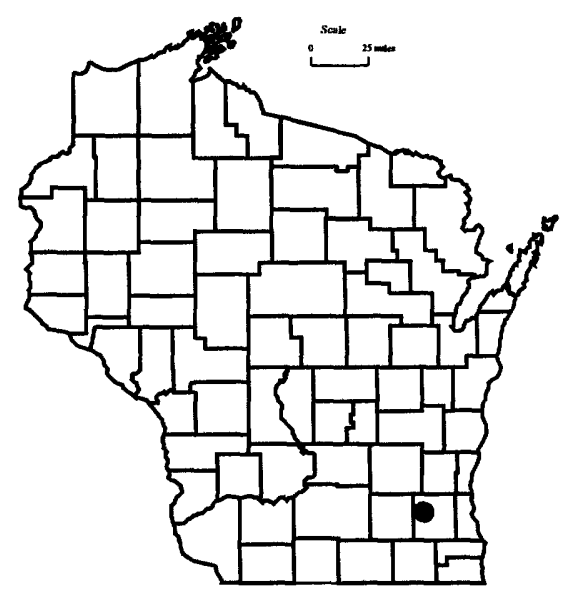




\section{WESTERN LAKE MICHIGAN DRAINAGES NATIONAL WATER-QUALITY ASSESSMENT (NAWQA), WI 17400}

PROBLEM: Growing populations throughout the United States have resulted in increased development and use of our water resources. As our water resources become stressed, decisions on how to effectively utilize and manage these resources will need to be made. These decisions must be based on accurate assessments of the quality of the water resource and the factors affecting its use.

OBJECTIVE: The long-term goals of the NAWQA project are to determine the water quality of the streams and aquifers in the Western Lake Michigan Drainages (WMIC), determine the presence or absence of any trends in the water quality, and provide an understanding of the link between natural and anthropogenic factors and observed water quality. Specific goals are (1) to determine the occurrence and spatial distribution of a broad array of water-quality constituents in ground and surface water and stream-bed sediments, (2) determine the occurrence of contaminants in selected target taxa, (3) evaluate the aquatic habitat and community structure of streams in the study unit, (4) assess the surface- to ground-water interaction and the effects of land use on base-flow water quality in selected stream reaches, (5) evaluate the sources and transport of selected hydrophilic compounds in agricultural settings, and (6) assess the influence of land use on shallow ground-water quality in selected landuse settings.

APPROACH: The foundation of the study approach is based upon identifying relatively homogeneous areas of specific land-use and environmental characteristics. Identification of these areas was accomplished by overlaying digital coverages of land use and various environmental variables using a geographic information system (GIS). Sampling sites completely contained in these relatively homogeneous areas (indicator sites) were incorporated into a nested design of surface-water, streambed sediment, and biological sampling. The sampling strategy consists of a retrospective analysis of available water-quality data (1991-1993), followed by a high (19931995) and then a low-phase (1996-2000) data-collection effort, followed by a data analyses and planning year (2001) and another highphase (2002-2004) data-collection effort. Monitoring of basic fixed sites (BFS) in selected areas (indicator sites), as well as downstream sites draining heterogeneous land uses and environmental characteristics (integrator sites), are being conducted. These sites have been sampled monthly and augmented with event-related samples. A subset of these sites were extensively sampled for pesticides. Pesticide samples were collected approximately weekly during the early to mid-summer period and less frequently during the rest of the year. Synoptic studies were conducted during high- and low-flow conditions (spring and summer of 1994) to better delineate the sources of nutrients throughout the basins and describe the seasonal variability of these sources. Another synoptic study determined how representative the BFSs were of the entire WMIC drainage area. Other program components include an ecological survey (spring 1993) at 20 sites to evaluate the relation between community (fish and invertebrates), habitat structure, land-use practices, and environmental factors. Ground-water studies include a study-unit survey, a flow-path

\section{COOPERATOR:}

U.S. Geological Survey, Reston, Virginia

\section{LOCATIONS:}

Upper peninsula of Michigan from the Menominee River basin in the west to the Fishdam River basin in the east; and the eastern portion of Wisconsin to include the Menominee, Oconto, Peshtigo, Fox-Wolf River basins discharging to Green Bay, and in Wisconsin that directly drain into Lake Michigan from the west which include the Manitowoc, Sheboygan, Milwaukee, Root, and Pike River basins.

\section{PROJECT CHIEF:}

Charles A. Peters

\section{PERIOD OF PROJECT:} December 1990-Continuing

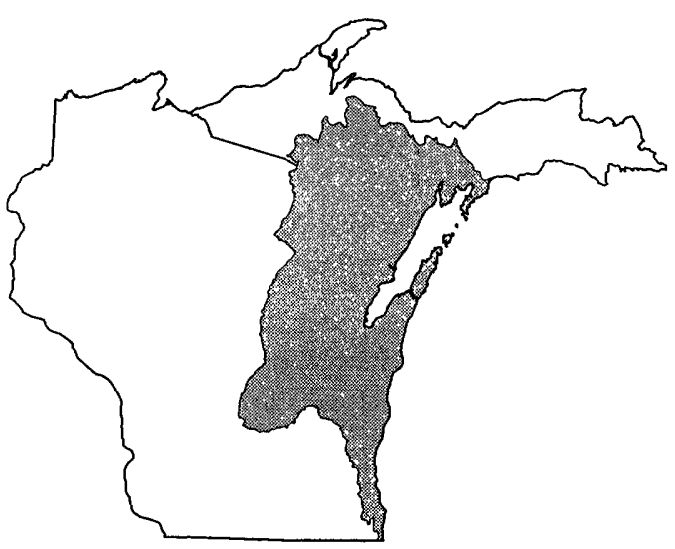


study and two land-use studies. The flow-path study examined tranformations in various constituents through time and space. Surfacewater/ground-water interactions were examined using shallow wells and lysimeters installed adjacent to the nearby stream. Effects of land use on ground-water quality were assessed through sampling in specific relatively homogeneous areas (1994 and 1995). A study unit survey provides an indication of water-quality conditions of the major aquifer (Cambrian-Ordovician sandstone) in the study unit.

PROGRESS (July 1999 to June 2000): Two low-intensity phase (LIP) basic fixed sites (BFS) were sampled monthly for discharge, field parameters, nutrients, pesticides, major ions, total and dissolved organic carbon, and suspended sediment. One of these sites was sampled for pesticides biweekly during the growing season.

The GIS coverages compilation was completed. Ancillary data for all ground-water wells was compiled. Data archiving, for data collected during the high- and low-intensity phases, was completed. The study unit's World Wide Web page has been updated and maintained. Data from the high-intensity phase was analyzed and the results of analyses compiled in reports.

Reports on basic fixed site macroinvertebrates, basic fixed site algae, benchmark stream algae, and algal dynamics are being prepared.

PLANS (July 2000 to June 2001): Two low-intensity phase (LIP) basic fixed sites (BFS) will be sampled monthly for discharge, field parameters, nutrients, major ions, total and dissolved organic carbon, and suspended sediment. The two BFS will have ecological assessments for fish, algae and invertebrate population and habitat conducted. Bed sediment and tissue samples will be collected for trace element and organic analyses.

Data and information collected during the first high-intensity phase (HIP) will continue to be compiled, maintained and archived. The World Wide Web home page development and maintenance will continue.

Data from the high-intensity phase, the low-intensity phase, as well as other data collected by other projects in the study area during the years 1991 to 2001 will be analyzed and the results of analyses compiled in reports. Three water-resources investigations reports and a journal article will be completed for distribution.

\section{REPORTS:}

Lenz, Bernard N. and Rheaume, S.J., 2000, Benthic invertebrates of fixed sites in the Western Lake Michigan Drainages, Wisconsin and Michigan, 1993-1995: U.S. Geological Survey WaterResources Investigations Report 95-4211-D, 30 p. 


\section{UPPER ILLINOIS RIVER BASIN \\ NATIONAL WATER-QUALITY ASSESSMENT (NAWQA), WI 17402}

PROBLEM: Growing populations throughout the United States have resulted in increased development and use of our water resources. As our water resources become stressed, decisions on how to effectively utilize and manage these resources will need to be made. These decisions must be based on accurate assessments of the quality of the water resource and the factors affecting its use.

OBJECTIVE: The long-term goals of the NAWQA project are to determine the water quality of the streams and aquifers in the Upper Illinois River Basin (UIRB), determine the presence or absence of any trends in the water quality, and provide an understanding of the link between natural and anthropogenic factors and observed water quality. Specific goals are to (1) determine the occurrence and spatial distribution of a broad array of water-quality constituents in ground and surface water and streambed sediments, (2) determine the occurrence of contaminants in selected target taxa, (3) evaluate the aquatic habitat and community structure of streams in the study unit, (4) assess the effects of urbanization on surfacewater quality in selected stream reaches, (5) evaluate the sources and transport of selected hydrophilic compounds in agricultural settings, and (6) assess the influence of land use on shallow ground-water quality in selected land-use settings.

APPROACH: The foundation of the study approach is based upon identifying relatively homogeneous areas of specific land-use and environmental characteristics. Identification of these areas was accomplished by overlaying digital coverages of land use and various environmental variables using a geographic information system (GIS). Sampling sites completely contained in these relatively homogeneous areas (indicator sites) were incorporated into a nested design of surface-water, streambed sediment, and biological sampling. The sampling strategy consists of a retrospective analysis of available water-quality data (1997-1999), followed by a high (19992001) and then a low-phase (2002-2006) data-collection effort. Monitoring of basic fixed sites (BFS) in selected areas (indicator sites), as well as downstream sites draining heterogeneous land uses and environmental characteristics (integrator sites), are being conducted. These sites will be sampled monthly and augmented with event-related samples. A subset of these sites will be extensively sampled for pesticides and volatile organic compounds. Pesticide samples will be collected approximately biweekly during the early to mid-summer period and less frequently during the rest of the year. Volatile organic compound samples will be collected weekly during the winter and less frequently during the rest of the year. Other program components include an urban gradient study to evaluate the relation between community (fish, algae, and invertebrates), habitat structure, land-use practices, and environmental factors. Groundwater studies include a study-unit survey and two land-use studies.

The land-use survey studies the effects of land use on ground-water quality through sampling in specific relatively homogeneous areas (1999 and 2000). A study unit survey provides an indication of water-quality conditions of the major aquifer (Silurian-Devonian) in the study unit.
COOPERATOR:

U.S. Geological Survey

Reston, Virginia

LOCATIONS:

Upper Illinois River Basin in

Illinois, Indiana, and Wisconsin

PROJECT CHIEF:

Daniel J. Sullivan

PERIOD OF PROJECT:

October 1996-Continuing

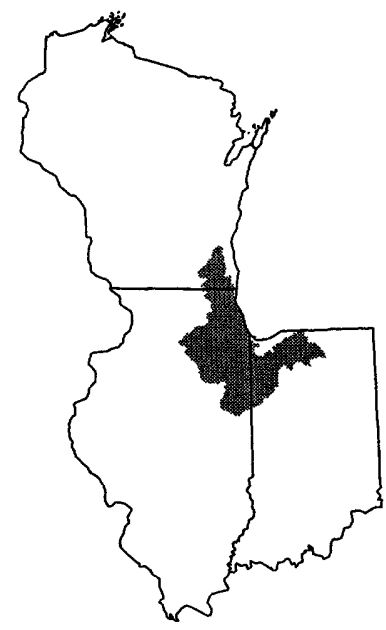


PROGRESS (July 1999 to June 2000): The GIS coverages will continue to be compiled, including: labeling the clustered Landsat data, wetlands data from the WISCland inventory, Natural Resource Inventory, Toxic Release Inventory, etc. Data archiving, for data collected during the pilot study (1987-1992), has continued. Retrospective nutrient and sediment data were analyzed and the results of analyses compiled for a report published in April 2000 .

Land-use gradient special study sites were selected. Reconnaissance of sites was completed in December 1999. Special study design plans were presented to several local, watershed, and state agencies in Illinois and the Environmental Protection Agency. Continuous temperature probes were installed at all sites in April 2000. The first draft of retrospective report was completed in May 2000.

PLANS (July 2000 to June 2001): Nine surface-water BFS will be sampled monthly for discharge, field parameters, nutrients, major ions, total and dissolved organic carbon, and suspended sediment. Samples will be collected for pesticide analyses at three BFS.

Data from the high-intensity phase will continue to be analyzed and the results of analyses compiled in reports. In-situ temperature monitors will be installed at all BFS in 2000 .

Ecological sampling will be conducted as part of a land-use gradient study in July 2000 . Water and sediment chemistry samples will be submitted in July-September 2000. Geomorphic and cross-section surveys will be conducted in fall/winter of 2000 and early spring 2001.

\section{REPORTS:}

Sullivan, Daniel J., 2000, Nutrients and suspended solids in surface waters of the Upper Illinois River Basin in Illinois, Indiana, and Wisconsin, 1978-97: U.S. Geological Survey WaterResources Investigations Report 99-4275, 57 p. 


\section{TECHNICAL ASSISTANCE IN THE DEVELOPMENT OF REGIONAL NUTRIENT CRITERIA FOR THE NATION, WI 17406}

\begin{abstract}
PROBLEM: The U.S. Environmental Protection Agency (EPA) is required by the Clean Water Act to develop nutrient criteria for surface-water bodies of the United States. The planned approach to define these criteria is based on an EPA ecoregion framework and the use of historical data assembled in STORET. Ecoregions are defined by relative differences in various environmental characteristics. Because each environmental characteristic is not equally weighted in defining the ecoregions, the divisions among ecoregions are rather arbitrary and differences in water quality among ecoregions are difficult to attribute to any specific environmental factor. In addition, because the most important environmental characteristics used to define the ecoregion divisions may not be the primary factors affecting water quality, larger variations in water quality may occur within an ecoregion than among ecoregions. Therefore, there may be a more refined regional framework that could be used to define nutrient criteria than EPA ecoregions.
\end{abstract}

OBJECTIVE: The objectives of this study are to (1) determine the most important environmental characteristics affecting nutrient (phosphorus and nitrogen) concentrations over the Upper Mississippi River Basin (the Mississippi River Basin above the confluence with the Missouri River), (2) use spatial differences in these constituents to develop a consistent regional framework to define nutrient criteria for this area, and (3) describe the background concentrations and variability in these concentrations for each of the areas within this new framework.

\begin{abstract}
APPROACH: The approach will be as follows: (1) assemble water-quality data from the USGS National Water-Quality Assessment (NAWQA) Program study units in the Upper Mississippi River Basin (UMRB), Illinois EPA, and Wisconsin Department of Natural Resources (WDNR); (2) delineate drainage basins and use a Geographic Information System (GIS) to determine the environmental characteristics of each basin, (3) use multivariate statistics (stepwise multiple regression and regression tree analysis) to relate waterquality (total phosphorus and total nitrogen) and environmental characteristic data; (3) determine the relative importance of various environmental characteristics in affecting water quality and how they should be used to divide the UMRB into relatively homogeneous water-quality regions; (4) describe the distribution of nutrient concentrations in each region; (5) define background concentrations for each region; and (6) compare resulting regional framework with the proposed EPA ecoregion approach.
\end{abstract}

PROGRESS (July 1999 to June 2000): All water-quality data were assembled for each of the basins. The environmental characteristics of each basin were defined using GIS. All water-quality data and environmental data were incorporated into ArcView. Preliminary statistics were performed.

PLANS (July 2000 to June 2001): Statistical analyses will be completed. Stratification will be compared with the present EPA ecoregions. A final report will be prepared.
COOPERATOR:

U.S. Environmental Protection Agency

LOCATION:

Upper Midwest

PROJECT CHIEF:

Dale M. Robertson

PERIOD OF PROJECT: July 1999 to September 2001

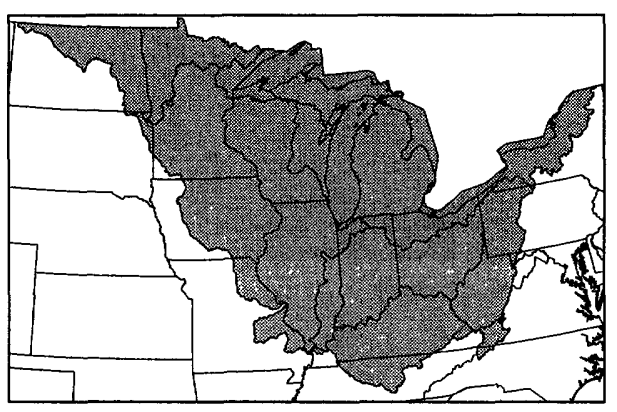




\section{HYDROLOGIC AND BIOGEOCHEMICAL BUDGETS IN TEMPERATE LAKES AND THEIR WATERSHEDS, NORTHERN WISCONSIN, WI 17500}

COOPERATOR:

Global Change Hydrology Pro-

gram, U.S. Geological Survey

LOCATION:

North-central Wisconsin

PROJECT CHIEFS:

John F. Walker

David P. Krabbenhoft

John F. Elder

PERIOD OF PROJECT: October 1990-Continuing

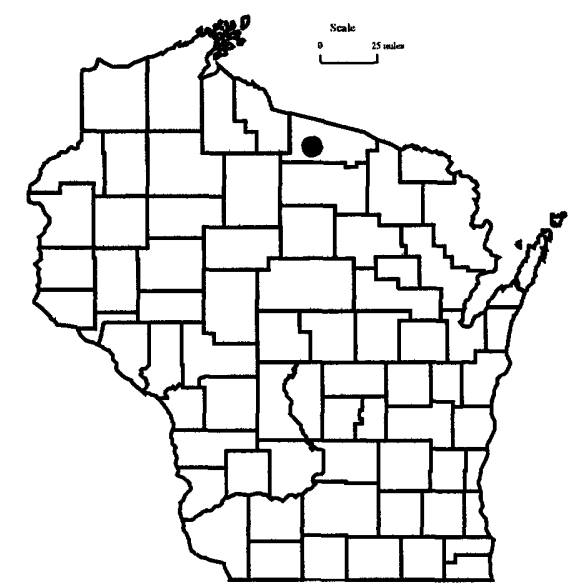

PROBLEM: There has been expanding evidence that rates of global changes are increasing. There is a need for research to identify, describe, and quantify the processes that control the Water, Energy, and Biogeochemical Budgets (WEBB) of aquatic ecosystems in order to understand and predict their responses to global changes. Promotion of such research is the function of the Water Resources Division's WEBB program. In the northern highlands lakes district of north-central Wisconsin, five lakes and two bog lakes have been the site of long-term ecological research conducted by University of Wisconsin scientists for the past decade. These studies have provided extensive information about biological and chemical features of the lake systems, but understanding of interactions among the lakes, streams, ground-water system, and wetlands is still limited. Research is urgently needed to describe these interactions and basin-wide processes that influence the character of the lakes.

OBJECTIVE: Objectives are to (1) describe processes controlling water and solute fluxes in northern Wisconsin lake watersheds, (2) examine interactions among those processes and their relations to climatic variables, and (3) improve the capability to predict changes in water and solute fluxes for a range of spatial and temporal scales. Fulfillment of these objectives in Wisconsin will contribute to meeting the overall objective of the federal global change program - to understand processes underlying the responses of hydrologic, biologic, and chemical systems to climate variations and human activities.

APPROACH: Selected streamflow/recharge sites on tributaries of Trout Lake are the sites for detailed research of hydrologic processes. Most of the current research effort is concentrated at Allequash Creek, one of four inflowing tributaries of Trout Lake. Analyses of hydrologic connections among precipitation, streamflow, and ground water are conducted at three cross sections of the Allequash Creek basin. Monitoring and sampling equipment installed at these sites include piezometer nests, lysimeters, tensiometers, precipitation collectors, and thermocouple nests. Analyses of stable isotopes (C-13, O-18, $\mathrm{Sr}-86$, and deuterium) are also used to determine water exchange pathways and sources of stream water. The site-specific hydrologic research is supported by data from several rain gages throughout the study area and a complete climatological station in the vicinity.

Stream- and ground-water samples, collected at each of the Trout Lake tributaries and at different points in the Allequash system, undergo analysis for nitrogen species, phosphorus, silica, organic carbon, major ions, and metals. Tributary sampling is done on a monthly basis, supplemented with more intense sampling of particular storms. Coupled with hydrologic data, the water sampling provides a basis for describing chemical budgets.

Investigation of geochemical processes that control transport of important chemical species across stream and lake sediments involves fine-scale sampling at the sediment/water interface. This is done by a variety of techniques, including membrane equilibrators, core squeezing, microprobes, and seepage meters. 
PROGRESS (July 1999 to June 2000): Ongoing data-collection efforts have continued. These include collecting samples at the streams tributary to Trout Lake, operating 5 continuous-record stream gages, monitoring water levels in a network of 22 wells, monitoring tension in 44 tensiometers, and collecting samples from 36 zero-tension and 31 suction lysimeters. One paper was published this past year, along with a fact sheet describing the research highlights during the past eight years. An additional publication investigating phosphorus dynamics in hydrologically distinct wetland systems is in press. Work continued on four new research efforts, including a comparison of solute budgets across the five WEBB sites, a unified approach to watershed modeling applied to the five WEBB sites, comparison of land-use history and sediment and carbon budgets across the five sites, and an investigation of macroinvertebrate populations and energy dynamics in the Allequash Creek system. Data and other information about the project are available on a World Wide Web home page (http://infotrek.er.usgs.gov/doc/ WEBB/index.hmtl).

PLANS (July 2000 to June 2001): Basic datacollection efforts will continue, as well as datacollection efforts related to flow-path studies, carbon dynamics in the hyporheic zone, unsaturated zone processes, and macroinvertebrate dynamics. A variety of papers currently in preparation will likely be published, including one paper related to carbon sources and yields in the tributary streams to Trout Lake, an overview of the flow paths and geochemical dynamics of Allequash Creek, a paper describing the ground-water-flow modeling along the isthmus between Crystal Lake and Big Muskellunge Lake, a paper describing the use of CFCs to trace ground water originating from lakes, and a paper describing the modular modeling effort.

\section{REPORTS:}

Elder, J.F., Goddard, G.L., and Homant, P.R., Phosphorus retention and yields in hydrologically different types of wetland systems in Wisconsin (USA), in Proceedings of Societas Internationalis Limnologiae, Dublin, Ireland (in press).

Elder, J.F., Rybicki, N.B., Carter, V., and Weintraub, V., 2000 , Sources and yields of dissolved carbon in Northern Wisconsin stream catchments with differing amounts of peatland: WETLANDS, v. 20, no. 1, p. 113-125.

Walker, J.F. and Bullen, T.D., 1999, Trout Lake, Wisconsin: A water, energy and biogeochemical budgets program site, U.S. Geological Survey Fact Sheet 134-99, $4 \mathrm{p}$.

Hunt, R.J., Anderson, M.P., and Kelson, V.A., 1998, Improving a complex finite-difference ground water flow model through the use of an analytic element screening model: Ground Water, v. 36, no. 6, p. 1011 1017.
Hunt, R.J., Kelson, V.A., and Anderson, M.P., 1998, Linking an analytic element code to MODFLOWImplementation and benefits, in MODFLOW 98: Proceedings of the 3rd International Conference of the International Groundwater Modeling Center, Golden, Colorado, Colorado School of Mines, p. 497504.

Keating, E.H., and Bahr, J.M., 1998, Using reactive solutes to constrain groundwater flow models at a site in northern Wisconsin: Water Resources Research, v. 34 , no. 12 , p. 3561-3571.

Keating, E.H., and Bahr, J.M., 1998, Reactive transport modeling of redox geochemistry: Approaches to chemical disequilibrium and reaction rate estimation at a site in northern Wisconsin: Water Resources Research, v. 34, no. 12, p. 3573-3584.

Schindler, J.E., and Krabbenhoft, D.P., 1998, The hyporheic zone as a source of dissolved organic carbon and carbon gases to a temperate forested stream: Biogeochemistry, v. 43, p. 157-174.

Walker, J.F., and Krabbenhoft, D.P., 1998, Groundwater and surface-water interactions in riparian and lakedominated systems, in McDonnell, J.J., and Kendall, C., eds., Isotope tracers in catchment hydrology: Amsterdam, The Netherlands, Elsevier, p. 467-488.

Elder, John F., Carter, Virginia, and Rybicki, N.B., 1998, Dissolved carbon mobilization in peatland/stream systems in northern Wisconsin (U.S.A.), Proceedings of V INTECOL Wetlands Symposium, Perth, Australia (in press).

Bullen, Thomas D., Krabbenhoft, D.P., and Kendall, Carol, 1996, Kinetic and mineralogic controls on the evolution of groundwater chemistry and $87_{\mathrm{Sr}} / 86_{\mathrm{Sr}}$ in a sandy silicate aquifer, northern Wisconsin, U.S.A., Geochimica et Cosmochimica Acta, v. 60, no. 10, p. 1807-1821.

Krabbenhoft, D.P., Benoit, J.M., Babiarz, D.L., Hurley, J.P., and Andren, A.W., 1995, Mercury cycling in the Allequash Creek Watershed, northern Wisconsin, Water, Air, and Soil Pollution, v. 80, p. 425-433.

Keating, E.H., 1995, Reactive transport modelling: an application to redox geochemistry of groundwater discharging to a stream in northern Wisconsin, Ph.D. thesis, University of Wisconsin-Madison, Madison, Wisconsin, $216 \mathrm{p}$.

Krabbenhoft, D.P., Bowser, Carl J. Kendall, C., and Gat, J.R., 1994, Use of oxygen-18 and deuterium to assess the hydrology of groundwater-lake systems, in Environmental Chemistry of Lakes and Reservoirs (L.A. Baker, editor), American Chemical Society, p. 67-90.

Elder, John F., Krabbenhoft, David P., and Walker, John F., 1992, Water, Energy, and Biogeochemical Budgets (WEBB) program: data availability and research at the Northern Temperate Lakes site, Wisconsin: U.S. Geological Survey Open-File Report 92-48, 15 p. 


\section{ASSESSMENT OF THE HYDROLOGY, WATER QUALITY, AND BIOLOGY OF DELAVAN LAKE, WI 18101}

COOPERATOR:

Town of Delavan

LOCATION:

Walworth County

PROJECT CHIEF:

Gerald L. Goddard

Dale M. Robertson

PERIOD OF PROJECT: August 1983-Continuing

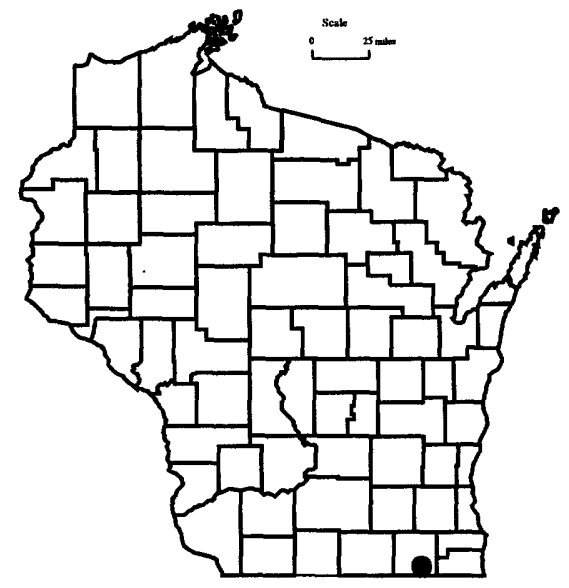

PROBLEM: Eutrophication of Delavan Lake has accelerated since the 1940s, resulting in a hypereutrophic lake with extensive blue-green algae blooms. Extensive rehabilitation efforts were implemented in 1990-1992 to improve the lake's water quality. Monitoring of the lake and nutrient and sediment loads to the lake is continuing to determine the effectiveness of the rehabilitation effort.

OBJECTIVE: The objectives are to quantify the effectiveness of rehabilitation efforts by measuring streamflow and nutrient and suspended-sediment loads at Jackson Creek tributary near Elkhorn, Jackson Creek at Mound Road (wetland outlet) and Highway 50 and at the lake's outlet; measuring water quality, and phytoplankton and zooplankton populations in the lake; and determining the trapping efficiency of wetland for phosphorus and suspended sediment.

APPROACH: Nutrients, suspended sediments, and streamflow are monitored at Jackson Creek tributary, the wetland outlet at Mound Road, at Highway 50, and the lake outlet. Nutrient concentrations, dissolved oxygen, water temperature, $\mathrm{pH}$, specific conductance, and planktonic populations are monitored within the lake. The effectiveness of the wetland is estimated by examining changes in the morphometry of the wetlands and changes in phosphorus and suspended sediment export at Mound Road.

PROGRESS (July 1999 to June 2000): Streamflow was monitored continuously at three inflow sites and at one outflow site. Water samples were collected monthly and during storm runoff events at all stream sites. Water samples were analyzed for nutrients and suspended sediment. The water quality at the center of the lake was monitored. The 1999 water-year data was compiled for publication in the report, "Water Resources Data-Wisconsin". A journal article describing what can be expected following a successful alum treatment was published. Lake phosphorus concentrations in 19961999 were similar to those prior to rehabilitation that was completed in 1993. Summer water clarity was greater and chlorophyll $a$ concentrations approached conditions similar to those prior to lake rehabilitation.

PLANS (July 2000 to June 2001): The monitoring program will be continued. Data will be compiled for publication. A journal article describing changes in the lake from 1983-1998 will be published.

\section{REPORTS:}

Robertson, D.M., Goddard, G.L., Helsel, D.R., and MacKinnon, K.L., 2000, in press, Rehabilitation of Delavan Lake, Wisconsin: Lake and Reservoir Management, v. 20, no. 1.

Panuska, J.C., and Robertson, D.M., 1999, Estimating phosphorus concentrations following alum treatment using apparent settling velocities: Lakes and Reservoir Management, v. 15, no. 1, p. 28-38. 
Robertson, D.M., Elder, J.F., Goddard, G.L., and James, W.F., 1998, Dynamics in phosphorus retention in wetlands upstream of Delavan Lake, Wisconsin: Lakes and Reservoir Management, v. 14 , no. 4 , p. $466-477$.

Elder, J.F., Manion, B.J., and Goddard, G.L., 1997, Mesocosm experiments to assess factors affecting phosphorus retention and release in an extended Wisconsin wetland: USGS WaterResources Investigations Report 97-4272, 14 p.

Goddard, G.L., and Elder, J.F., 1997, Retention of sediments and nutrients in Jackson Creek Wetland near Delavan Lake, Wisconsin, 1993-95, USGS Water-Resources Investigations Report 97-4014, 22 p.

Elder, J.F. and Goddard, G.L., 1996, Sediment and nutrient trapping efficiency of a constructed wetland near Delavan Lake, Wisconsin, 1993-1995: U.S. Geological Survey Fact Sheet 232-96.

Robertson, D.M., Field, S.J, Elder, J.F., Goddard, G.L., and James, W.F., 1996, Phosphorus dynamics of Delavan Lake inlet in southeastern Wisconsin. U.S. Geological Survey WaterResources Investigations Report 96-4160, 18 p.

Field, Stephen J., and Duerk, Marvin D., 1988, Hydrology and water quality of Delavan Lake in southeastern Wisconsin: U.S. Geological Survey Water-Resources Investigations Report 87$4168,61 \mathrm{p}$. 


\section{LAKE MICHIGAN TRIBUTARY LOADING, WI 18300}

\section{COOPERATORS:}

U.S. Environmental Protection Agency

\section{LOCATION:}

Cities of Marinette, Green Bay, Milwaukee and Sheboygan

\section{PROJECT CHIEF:}

David W. Hall

PERIOD OF PROJECT: July 1992 to September 2001

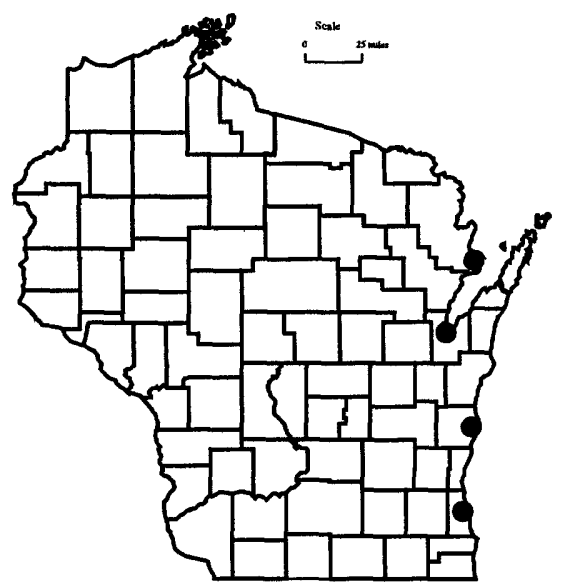

PROBLEM: Concern about the potential negative health and biologic effects of toxic chemicals and heavy metals being transported into Lake Michigan has increased with growing evidence of links between the presence of these contaminants and carcinogens in fish, genetic defects in fish-eating birds, and reproductive disorders in biota. Adequate management of chemical loads requires that the total contribution of contaminants from atmospheric, ground water, and tributary rivers be quantified.

OBJECTIVE: Objectives of this project are to build a streamflow and water-quality database for 11 Lake Michigan tributaries: the Menominee, Fox, Sheboygan, and Milwaukee Rivers in Wisconsin; the Grand Calumet in Indiana; and the St. Joseph, Kalamazoo, Grand, Muskegon, Pere Marquette, and Manistique Rivers in Michigan. The water-quality database will act as a baseline for evaluation of future remediation activities. Data will be used to compute loads of PCBs, trans-nonachlor, atrazine, trace metals, nutrients, and suspended solids to Lake Michigan. Data from the 11 monitored tributaries will be extrapolated to all unmonitored areas of the basin to provide an estimate of total tributary water and contaminant loading to Lake Michigan. Project data will be used to identify tributaries of greatest concern for remediation activities, identify contaminants of greatest concern, and to describe the sources, fate, and transport of contaminants. A primary objective of this study is to provide tributary data for input into the U.S. Environmental Protection Agency's (USEPA) Lake Michigan Mass Balance model.

APPROACH: The Wisconsin District will install acousticvelocity-metering (AVM) stations at the mouths of the four Wisconsin tributaries, including the Milwaukee, Sheboygan, Fox, and Menominee Rivers to provide real-time flow and water-quality data. Field sampling will be scheduled to obtain approximately 75 percent of the samples during non-baseflow periods. Composited samples for analyses of congener-specific PCBs and pesticides will be field filtered and processed through XAD-2 resin columns. Composited samples for analyses of particulate and dissolved trace metals will be obtained using clean sampling protocols. Data will be entered into the WATSTORE and ADAPS databases.

PROGRESS (July 1999 to June 2000): Load computations for all parameters were completed with the exception of estimation of PCB loads entering Lake Michigan from unmonitored areas. All loads have been reported to the USEPA Great Lakes National Program Office (GLNPO) and the USEPA Lake Michigan Mass Balance modeling group in Grosse Ile, Michigan. A USEPA intern was trained at the USGS district office and has been reassigned to USEPA GLNPO offices in Chicago, Illinois, to conduct long-term project maintenance activities associated with the project.

PLANS (July 2000 to June 2001): USGS will supervise USEPA intern in completion of remaining load computations and tributary sections of four USEPA Mass Balance Model project reports. A fact sheet will be published to document total PCB loads in the 11 monitored tributaries. 


\section{REPORTS:}

Hall, D.W., and Behrendt, T.E., 1995, Polychlorinated biphenyls and pesticides in Lake Michigan Tributaries: East Lansing, Michigan, International Association for Great Lakes Research Conference: Programs and Abstracts, May 28 - June 1, 1995.

Hall, D.W., Behrendt, T.E., and Hughes, P.E., 1998, Temperature, $\mathrm{pH}$, conductance, and dissolved oxygen in cross sections of 11 Lake Michigan Tributaries, 1994-95: U.S. Geological Survey Open-File Report 98-567, 85 p. 


\section{TRACE METAL LOADING TO LAKES MICHIGAN AND SUPERIOR, WI 18301}

COOPERATOR:

Wisconsin Department of Natural Resources

LOCATION:

United States portion of Lake Michigan and Lake Superior Basins

\section{PROJECT CHIEF:}

Dale M. Robertson

PERIOD OF PROJECT: October 1997-December 1999

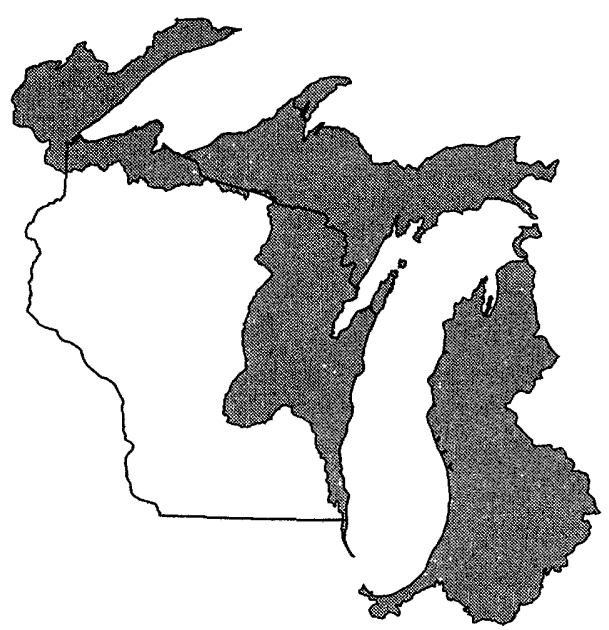

PROBLEM: The delivery of trace metals from point and nonpoint sources poses serious concerns for the coastal and offshore ecosystem of the Great Lakes. Though point-source loadings can be significant, evidence suggests that nonpoint-source contributions of metals exceed that of point sources. The tributary monitoring component of the Lake Michigan Mass Balance (LMMB) study will provide total loads of selected metals from the selected tributaries, but will not support source reconciliation.

OBJECTIVE: The objectives of this study are to (1) develop tributary load estimates of selected metal constituents to Lake Michigan and the U.S. portion of Lake Superior from both monitored and unmonitored watersheds, (2) describe what environmental factors influence the relative loading, and (3) separate the load into urban and nonurban components.

APPROACH: The approach used is as follows: (1) Develop geographic information system (GIS) coverages of the environmental factors thought to influence the distribution of the selected metals; (2) subdivide the entire basin into areas of relatively homogeneous environmental characteristics; (3) sample sites representing areas that have not been previously sampled; (4) compute loads for selected metals for the main tributaries and daily loads (high flow and base flow) for smaller indicator streams from relatively homogeneous areas; (5) use geographic information system (GIS) to determine environmental characteristics of main tributary basins and smaller indicator streams; (6) use multiple regression to relate loads from indicator sites to environmental characteristics; (7) use loads from smaller indicator areas with regression relations to estimate loading from ungaged areas and total regional loading; and (8) subtract the estimated watershed contribution from the total tributary load to estimate the urban inputs.

PROGRESS (July 1999 to December 1999): GIS data were obtained for land use, surficial deposits, bedrock types for the complete Lake Michigan and U.S. part of the Lake Superior watershed. Multiple regression was used to relate copper, lead, mercury, and zinc loads from indicator sites to environmental characteristics. The loads from smaller indicator areas were used to determine which environmental variables were most strongly related to loading for each constituent and used to estimate loading from ungaged areas and total regional loading to Lakes Michigan and Superior. Localized urban inputs were estimated by subtracting the watershed contributions from the total tributary load from indicator areas. A final report was submitted to the Environmental Protection Agency.

PLANS: Project is completed. 


\section{DANE COUNTY REGIONAL HYDROLOGIC STUDY, WI 18900}

PROBLEM: Officials at all levels of government are concerned about the effects of increasing urban growth and development on the surface- and ground-water resources in Dane County. The relation between surface water and ground water must be understood to allow for increased ground-water withdrawals while protecting the quality and quantity of surface-water resources in the county. A comprehensive study that combines existing water data with new data is needed to provide government and planning agencies with a tool to aid in managing the water resources of the Dane County area.

OBJECTIVE: The objective is to improve the understanding of the ground-water system in relation to surface water and to provide a tool (ground-water-flow model) that will be useful in waterresource management decision making on a continuing basis.

APPROACH: The study is divided into three phases: (1) establish conceptual framework of the ground-water system and database, (2) develop and calibrate three-dimensional ground-waterflow model, and (3) determine how land-use and management strategies effect water resources.

PROGRESS (July 1999 to June 2000): Simulations incorporating potential land-use and management strategies were run and the results given to the Dane County Regional Planning Commission. The flow model was calibrated to transient conditions. Baseflow estimates using current streamflow measurements were made for selected Dane County streams.

PLANS (July 2000 to June 2001): Simulations incorporating potential land-use and management strategies will be run at the request of the Dane County Regional Planning Commission.

\section{REPORTS:}

Krohelski, J.T., Bradbury, K.R., Hunt, R.J., and Swanson, S.K., 1997, Numerical simulation of ground-water flow in Dane County, Wisconsin: Wisconsin Geological and Natural History Survey Information Circular (in press).

Bradbury, K.R., Swanson, S.C., Krohelski, J.T., and Fritz, A.K., 1997, Hydrogeology of Dane County, Wisconsin: Wisconsin Geological and Natural History Survey (in review).
COOPERATORS:

Dane County Regional Planning

Commission

Wisconsin Geological and Natural

History Survey

LOCATION:

Dane County and parts of surrounding counties

PROJECT CHIEF: James T. Krohelski

PERIOD OF PROJECT: October 1992-Continuing

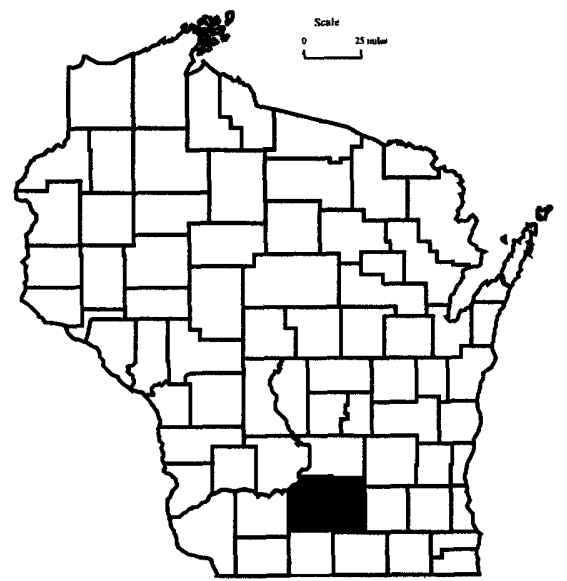


COOPERATOR:

Wisconsin Department of

Natural Resources

LOCATION:

Ozaukee County

PROJECT CHIEF:

Jeffrey J. Steuer

PERIOD OF PROJECT:

April 2000 to September 2001
PROBLEM: High concentrations of polychlorinated biphenyls (PCBs) have been found in the Cedar Creek bed sediments, water column, and fish tissues. Partial remediation (Ruck Impoundment) was completed in 1994. PCB transport trends are needed to assist in future management decisions.

OBJECTIVE: The objective is to determine $\mathrm{PCB}$ loading changes at Columbia Avenue (downstream of Ruck Impoundment) and Highland Road.

APPROACH: From August 1994 to August 1995, 24 PCB samples were collected at Columbia Avenue and Highland Road. Total suspended solids, chlorophyll $a$, and discharge data were used in conjunction with the PCB data to establish PCB concentration regression relations.

When sampling does begin, a total of 2480 -liter PCB samples (along supporting constituents) will be collected at the two Cedar Creek sites. Utilizing these data, residuals from the 1994/1995 regression relations will be examined to determine if PCB concentrations have changed over time.

PROGRESS (April 2000 to June 2000): Project planning has been completed and field sampling was planned to start in April 2000. Approval of a Quality Assurance Project Plan (QAPP) by EPA has been delayed and sampling will likely be delayed until the fall of 2000 .

PLANS (July 2000 to June 2001): Field operations will be continued.

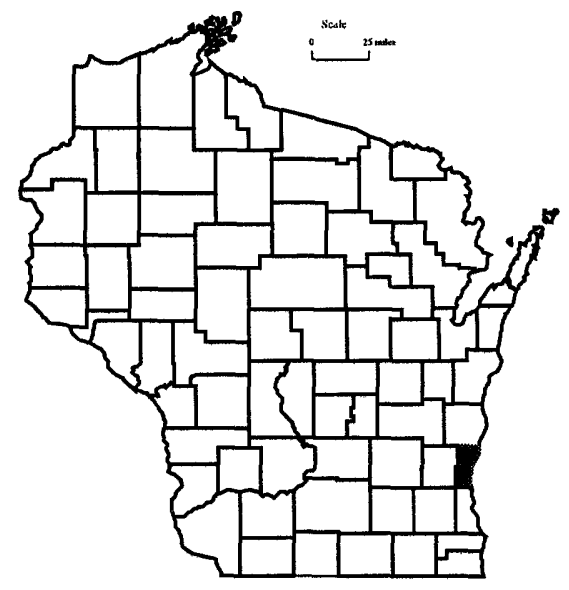




\section{FLORIDA EVERGLADES MERCURY CYCLING, WI 19700}

PROBLEM: Mercury contamination is one of the largest potential health risks to aquatic organisms, predatory animals, and humans. This great concern is the result of two observations: (1) mercury biomagnifies in the food chain to toxic concentrations even though it is found at very low aqueous concentrations and (2) the principal source to most areas is atmospheric deposition. Thus, almost any aquatic ecosystem with a food chain is potentially susceptible to mercury contamination.

OBJECTIVE: The overall objective of this project is to provide a better understanding of the mercury contamination problem in the Florida Everglades and other aquatic ecosystems. Specific processes will be investigated, including particle and dissolved transport, volatilization, methylation, and interactions with dissolved organic carbon.

APPROACH: A new direction and series of approaches is being implemented for the second phase of our mercury cycling research in the Everglades. Briefly, we are using wetland enclosures and stable isotope of mercury in a combined approach to address management questions in a more direct fashion than our previous studies could provide. For example, a series of replicate enclosures will have varying levels of mercury isotope added to the water column within them to simulate recent atmospheric mercury deposition. After the isotope addition, the rates at which the "new" mercury is methylated and incorporated into biota within the enclosures will be monitored. With this type of information, agencies responsible for directing Everglades restoration efforts can more reliably make decisions on what preventive actions can be made with regard to mercury toxicity in the Everglades.

PROGRESS (July 1999 to June 2000): Forty custommade wetland enclosures were manufactured and installed at four sites in the northern and central Everglades. In May, three enclosures at each site had ${ }^{202} \mathrm{Hg}$ added, and a fourth enclosure had sulfur added (a limiting constituent for mercury methylation). Samples were collected three times over a 7-day period after addition of the mercury and sulfur. Samples will be analyzed on the new Inductively Coupled Plasma Mass Spectrometer (ICPMS) that is operated by the Mercury Studies Team in the Wisconsin District Office.

PLANS (July 2000 to June 2001): Quarterly field trips will be conducted to repeat and expand the experimental approaches for the use of wetland enclosures and chemical additions to test the environmental response to the additions. Sample analysis and interpretations will be used to help guide each series of tests, in addition to asking other state and federal agencies for their input on questions we can possibly answer with these experiments. At the conclusion of the first three rounds of experiments, all the results will be compiled and reports will be drafted outlining the utility of these new approaches in our studies of mercury cycling in the Everglades.
COOPERATOR:

U.S. Geological Survey

Reston, Virginia

LOCATION:

Florida Everglades

PROJECT CHIEF:

David P. Krabbenhoft

PERIOD OF PROJECT: January 1995-Continuing

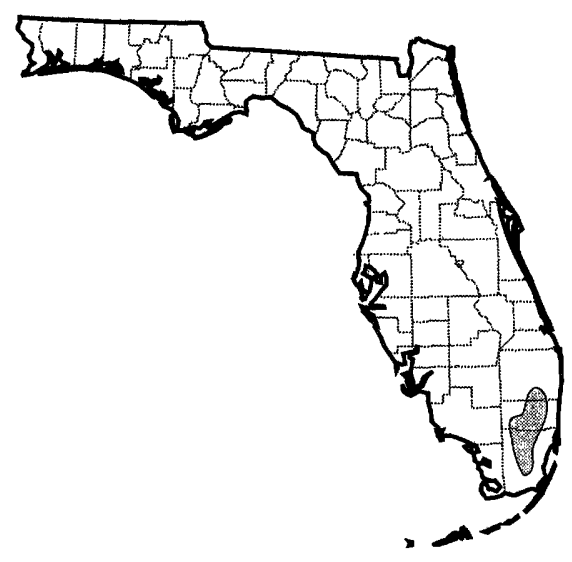




\section{MITIGATION OF FUTURE NORTH FORK URBANIZATION IMPACTS ON THE PHEASANT BRANCH HYDROLOGIC SYSTEM, WI 20200, 20202, 20203}

\section{COOPERATOR:}

City of Middleton

Wisconsin Department of Natural Resources

\section{LOCATION:}

Dane County

\section{PROJECT CHIEFS: Jeffrey J. Steuer \\ Randy Hunt}

\section{PERIOD OF PROJECT:} July 1996 to September 2002

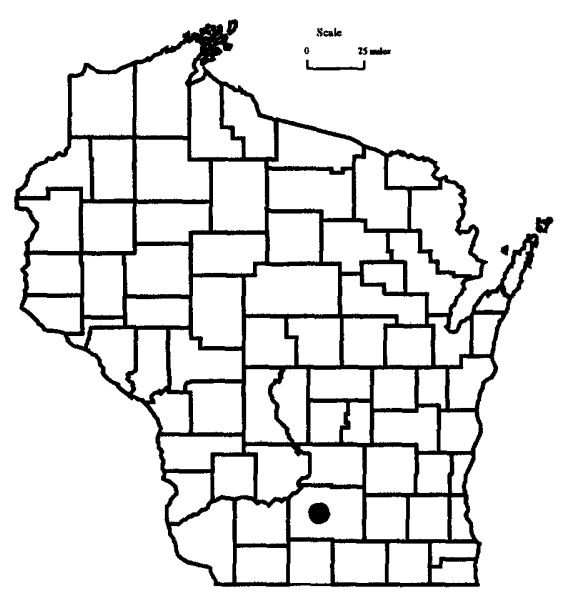

PROBLEM: As Middleton and its surroundings continue to develop, the Pheasant Branch North Fork Basin is expected to undergo significant urbanization. For the downstream city of Middleton, headwater urbanization can mean increased flood peaks, increased water volume and increased pollutant loads. It may also adversely effect down-gradient ecosystems such as Pheasant Branch Marsh and reduce ground-water recharge. Previous work has often not included the transient interaction between surface and ground water. The proposed work will combine ground- and surface-water modeling in the analysis of the Pheasant Branch system.

OBJECTIVE: Objectives are to (1) locate potential sites for runoff controls and/or enhanced infiltration to ensure future flood peaks do not exceed the present condition flood peaks, (2) quantify the flood peak and ground-water recharge differences resulting from a fully-urbanized condition with and without treatment or runoff controls, (3) use the ground-water model to assess North Fork basin urbanization impacts on Pheasant Branch Marsh, and (4) construct a ground-water model able to address future needs such as siting future water supply.

APPROACH: The overall approach will combine ground- and surface-water models to locate an effective combination of stormwater treatment or control sites within the North Fork basin which may be developed to produce minimal effects on the Pheasant Branch hydrologic system. The surface-water component will build upon the simulations detailed in "Effects of urbanization on streamflow, sediment loads, and channel morphology in Pheasant Branch Basin near Middleton, Wisconsin" (Krug and Goddard, 1985, WRIR 85-4068). To achieve the objectives of this project, the model will contain a spatial resolution to simulate 1 to 4 developments per square mile (approximately 40 model sub-areas). Significant development has occurred in the South Fork basin since 1981. Two of the areas simulated as not generating runoff in 1981 have developed and presently drain to the South Fork. It will be necessary to update the South Fork basin model to ensure that shifting of the North Fork hydrograph peak (due to runoff controls) will not produce an enhanced peak downstream of the confluence (Krug and Goddard, pages 16, 17). The new model efforts will calibrate to recently collected Pheasant Branch discharge and precipitation data collected at Highway 12.

The ground-water component will use a model constructed at a smaller scale than the recently developed Dane County model (Krohelski, et.al., in press) to have the appropriate resolution for the stormwater control alternatives. Similar to Krohelski, et.al., the model will be constructed using MODFLOW (McDonald and Harbaugh, 1988). Recharge results from the surface-water model will be input into the ground-water-flow model to assess the effects of management alternatives on ground-water recharge distribution and magnitude. The model will also calculate the changes in groundwater-derived baseflow in the system for the different alternatives and assess the effectiveness of recharge enhancement scenarios. 
In February 2000, the project was expanded when the models were accepted as part of an Environmental Protection Agency (EPA)/ National Science Foundation (NSF) research grant. The expanded research will be coordinated by the WDNR and UW-Madison. To further that effort, the surface-water model will be modified to incorporate research findings in local infiltration and temperature pollution. The ground-water model will be refined to include additional geologic data and hydrologic features near the Pheasant Branch Marsh. The refined model will then be used for optimization to further assess the effects of development on surface-water resources in the area.

PROGRESS (July 1999 to June 2000): Shallow well sites have been established in Pheasant Branch Marsh along with two continuous flow-monitoring and precipitation sites on the Pheasant Branch North and South Forks. Three additional rain gages have been added to the network. Double-ring infiltration tests (36) have been conducted with the results incorporated into the surface-water model. Discharge and water-quality loads (phosphorus and total suspended solids) have been published in the 1998 annual data report. Calibration is complete on a 50-flow plane, 21-hydrologicresponse unit model. Simulations have been conducted for moderate and heavy development scenarios.

Results from the initial modeling using the Dane County regional flow model showed that regional water (away from the immediate highlands) was needed to simulate measured spring flow. Porewaters within the wetland-creek complex were sampled for major ions and water isotopes. The fact sheet and supporting water-resources investigations reports (WRIRs) have been initiated.

Planning of work with the EPA/NSF research group began.

PLANS (July 2000 to June 2001): The fact sheet and supporting WRIRs will be completed. The calibrated surface-water model with the PRMS framework will be converted to the Modular Modeling System framework to allow incorporation of the infiltration and temperature pollution research. Additional physical and geochemical hydrologic data will be collected in the site area. The ground-water-flow model will be modified to include the insight gained from the new data. 


\section{MITIGATION OF FUTURE IMPACTS OF URBANIZATION ON THE BADGER MILL CREEK HYDROLOGIC SYSTEM, WI 20201}

COOPERATOR:

City of Madison

\section{LOCATION:}

Dane County

\section{PROJECT CHIEF:}

David W. Owens

PERIOD OF PROJECT: October 1997 to September 2000
PROBLEM: Urban development of the Badger Creek Watershed by the cities of Madison and Verona and the townships of Verona and Middleton will result in higher flood peaks and increased pollutant loading within the watershed. Mitigating these effects after urban development can be expensive and administratively difficult. To reduce costs and difficulties associated with land acquisition, the local governing bodies desire a proactive approach that will locate regional runoff treatment or control sites prior to development. To complete this assessment, hydrologic information needs to be collected to calibrate a surface-water model.

OBJECTIVE: The three objectives for this project are (1) collect streamflow and rainfall data at three sites within the Badger Mill Creek sub-watershed, (2) collect rainfall data at two additional sites within the basin, and (3) construct a surface-water model to assess the impacts of urbanization.

\begin{abstract}
APPROACH: The study has two components. (1) Field component-three new USGS gaging stations will be installed in the Badger Mill Creek sub-watershed. Flow will be continuously monitored and rainfall data will be collected. Water-quality samples will be taken during event flows to measure total and suspended solids, total and dissolved phosphorus and selected metals. Two additional remote rain-gage stations will be installed throughout the basin to determine the spatial variability of rainfall. (2) Surface-water model component-a storm-water management model (SWMM) will be constructed and calibrated with field data collected by the USGS during the summer of 1997. The spatial resolution of the model will simulate approximately one to four developments per square mile. Rain-gage data will be used to estimate the spatial distribution of rainfall for the basin.
\end{abstract}

PROGRESS (July 1999 to June 2000): Three gaging stations were operated throughout the year. The SWMM model was constructed and calibrated by May 2000 using the data collected in water years 1998 and 1999. The source-loading and management model was completed and turned over to the city of Madison to do the predictive model for full buildout.

PLANS: Project is completed. 


\section{MONITORING AND EVALUATION OF THE IMPACTS OF AIRCRAFT AND RUNWAY DEICERS ON THE KINNICKINNIC RIVER SURFACE-WATER RESOURCES, WI 20400}

PROBLEM: Milwaukee County is involved in an effort to reduce runoff of deicing chemicals from General Mitchell International Airport (GMIA) to Wilson Park Creek. Ethylene and propylene glycol based deicers are used during cold weather periods to deice aircraft, runways, and other paved areas used by aircraft. Glycol concentrations in stream samples collected during deicing events throughout the winters between 1996 and 1999 ranged from less than detection limits to $39,000 \mathrm{mg} / \mathrm{L}$ in GMIA outfalls (well above toxicity limits). A second concern is that runoff from a portion of the GMIA runways drains to a tributary of Oak Creek. An assessment is needed to determine if there are any toxic effects in the Oak Creek watershed due to GMIA runoff.

OBJECTIVE: The overall goals of the project are to evaluate changes in water quality in Wilson Park Creek due to implementation of deicer management at GMIA, assess the water-quality conditions in Oak Creek downstream from GMIA runoff, and fulfill obligations stated in the Wisconsin Department of Natural Resources (WDNR) stormwater permit for GMIA. Specific objectives are as follows: (1) Monitor surface water at four sites in the Wilson Park Creek watershed for water quality and flow during dry weather and runoff conditions. This monitoring is to be conducted before and after implementation of deicer management. (2) Determine changes in water quality and toxicity levels in Wilson Park Creek due to implementation of deicer management. (3) Monitor water quality and flow in the Oak Creek watershed downstream from GMIA runoff. This monitoring should quantify a suite of water-quality parameters that are of interest as stated in WPDES permit number WI-0046477-1 issued to GMIA by WDNR.

APPROACH: Flow is measured and samples are collected at one site upstream from airport runoff and four sites downstream. Assessments of water quality will be made on a yearly basis. After two years of post-management monitoring, comparisons between pre- and post-management data will be made to determine if changes in water quality have occurred.

PROGRESS (July 1999 to June 2000): An extensive runoff monitoring program has been in place since November 1996. The first two winters represent conditions before deicer management was implemented.The 1998-1999 winter represents data with partial deicer management. Nine sites were monitored the first year and four sites are currently being monitored. Flow, dissolved oxygen, water temperature and rainfall are being monitored continuously. Waterquality constituents are sampled selectively during deicer application events, baseflow, and one summer rainfall event per year. Glycol, biochemical oxygen demand, selected nutrients and selected metals analyses are being conducted. Microtox and bioassay analyses are being conducted for toxicity assessment. In situ fathead minnow assays were conducted upstream and downstream from airport runoff. Two journal articles were written summarizing the first two years of dissolved oxygen, water chemistry, and toxicity data.
COOPERATOR:

County of Milwaukee

\section{LOCATION:}

Milwaukee

PROJECT CHIEF:

Steven R. Corsi

PERIOD OF PROJECT:

November 1996-Continuing

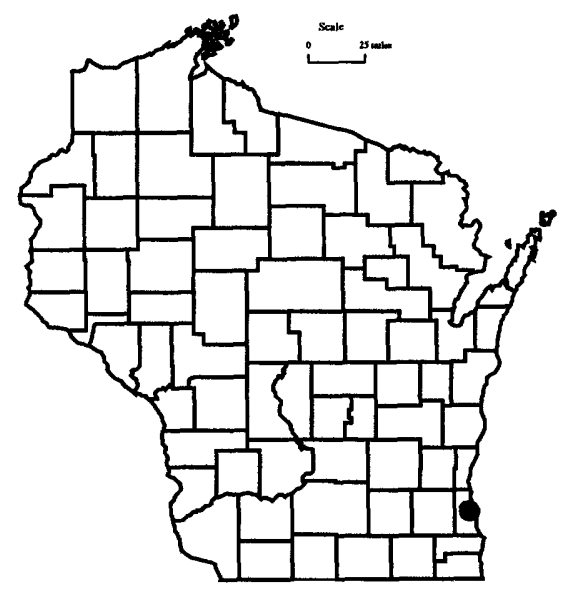


PLANS (July 2000 to June 2001): Two more years of monitoring are planned after the implementation of deicer management is expanded in the fall of 2000. After monitoring of post-implementation runoff, statistical analyses will be conducted to determine the effectiveness of the deicer management practice. A direct comparison of pre- to post-implementation data will be done using pairedwatershed and upstream-downstream analyses between sites. Three reports are planned. The first two reports will be journal articles describing the effects of deicing runoff on receiving streams and the third report will be an analyses of the effectiveness of the deicer management practice. 


\section{MODELING THE EFFECTS OF THE CRANDON MINE USING THE HSPF WATERSHED MODEL, WI 20500}

PROBLEM: The Nicolet Mining Company has proposed construction of a zinc and copper mine near Crandon, Wisconsin. Before any operations can begin, an environmental impact assessment must be written and approved. At present, it is uncertain what specific effects the mine will have on the hydrology and water quality of the streams and lakes in the area.

OBJECTIVE: The objectives of this project are to (1) assemble hydrologic, meteorologic, and land-use information for the area near the proposed mine, (2) develop a watershed model for the Swamp Creek basin, and (3) use the model to determine what potential impacts the mine will have on the hydrology of Swamp Creek and nearby lakes.

APPROACH: Available hydrologic, meteorologic and land-use information will be obtained from the U.S. Geological Survey databases, the Nicolet Mining Company, the Mole Lake Tribe, the Wisconsin state climatologist, the National Climatic Data Center, and the Wisconsin Department of Natural Resources. These data will be used to develop a watershed model for the Swamp Creek Basin using the Hydrologic Simulation Program Fortran (HSPF) watershed model. The model will be calibrated using a subset of data available for Swamp Creek and verified using an independent subset of the data. The model will be adjusted to simulate mine construction, operation, and closure. The output of the model will be used to quantify the effects of the mining operations on the water levels of streams and lakes in the area.

PROGRESS (July 1999 to June 2000): Hydrologic, meteorologic, and land-use information were assembled. Model calibration and verification were completed. Model scenarios are in progress and a report being written.

PLANS (July 2000 to September 2000): The calibrated HSPF model will be adjusted to quantify the effects of the mine construction, operation, and closure on the water levels of streams and lakes in the area. The report will be finalized and final GIS layers will be documented. Meetings will be conducted to present final results.
COOPERATOR:

U.S. Environmental Protection

Agency

LOCATION:

Forest County

PROJECT CHIEF:

Jana Stewart

PERIOD OF PROJECT:

January 1997 to September 2000

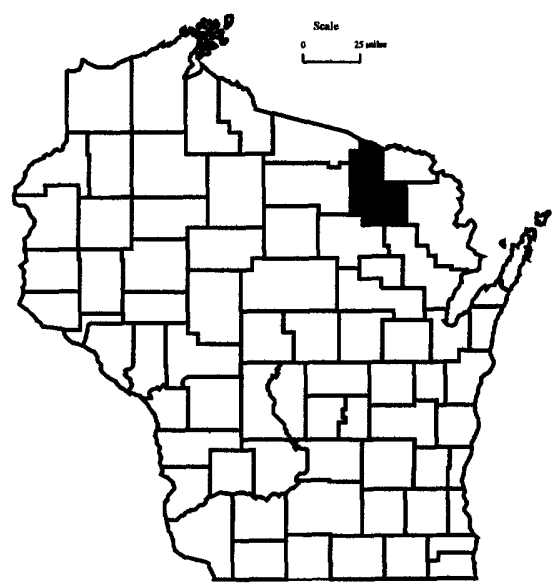




\section{DEVELOPING A GEOGRAPHIC INFORMATION SYSTEM (GIS) AND RE- LATIONAL DATABASE OF HSPF AND FEMWATER LAYERS USED IN MODELING EFFORTS RELATED TO THE PROPOSED CRANDON MINE, WISCONSIN, WI 20501}

\author{
COOPERATOR: \\ U.S. Army Corps of Engineers
}

LOCATION:

Forest County

PROJECT CHIEF:

Jana Stewart

PERIOD OF PROJECT:

October 1998 to September 2001
PROBLEM: A number of modeling efforts are underway to evaluate potential changes to surface- and ground-water resources in the vicinity of the proposed Crandon mine. The United States Army Corps of Engineers (USACE) is developing the FEMWATER model to evaluate potential changes in mine dewatering activities at the proposed Crandon Mine. The U.S. Environmental Protection Agency (USEPA) is working with the U.S. Geological Survey (USGS) and Aqua Terra Consultants, Inc. to develop a HSPF computer model for the simulation of the surface-water budget in the vicinity of the proposed mine. Although the objectives and scope of the two models differ, there is overlap between the areal extent of the models and the thematic data layers required for input, analysis, and interpretation. In areas where overlap occurs, an effort needs to be conducted to document similarities and differences between the spatial data layers used in each modeling effort.

OBJECTIVE: The objectives of this project are to (1) construct a database that describes the digital spatial data or other related data used in both modeling efforts, including geographic theme, source, areal extent, resolution, accuracy, and processing methods, (2) establish a digital data library of these layers using ARC/INFO and ArcView GIS, (3) produce map figures using GIS to show similarities and/or differences between layers, (4) summarize the findings of HSPF and FEMWATER data aggregation, and (5) use GIS analysis to support the needs of the monitoring team. As of March 2000 , the USACE decided to drop the FEMWATER model and will be releasing a new modeling plan on April 27, 2000.

APPROACH: The database will be constructed using a relational database. A digital data library will be built in ARC/INFO and ArcView GIS, with documentation included. Map figures will be produced in ArcView GIS and GIS analyses will be conducted using ARC/INFO to support impact assessment by USACE Waterways Experiment Station, Vicksburg, Mississippi. Analyses will be identified and planned based on the requirements of the monitoring team. The approach will be modified pending the release of the new USACE plan on April 27, 2000.

PROGRESS (July 1999 to June 2000): Preliminary meetings have been held with the monitoring team to identify their needs. A digital spatial data library has been established and thematic layers and figures have been compiled.

PLANS (July 2000 to June 2001): A digital spatial and relational database of HSPF, FEMWATER and related data layers will be built in ARC/INFO and ArcView GIS. Map figures of the database will be produced and findings of the data aggregation summarized. GIS analyses in support of monitoring assessment will be completed. Plans will be modified pending the release of the new USACE plan on April 27, 2000. 


\section{SOUTHEAST WISCONSIN GROUND-WATER, WI 20800}

PROBLEM: Much public attention has been focused in the last several years on the problem of insuring an adequate and inexpensive supply of water to southeastern Wisconsin in the next century. The southeastern Wisconsin communities of Waukesha, Brookfield, Germantown, Menominee Falls and Pewaukee are prohibited by the Great Lakes Charter from drawing water from Lake Michigan. Water utilities in these areas are concerned that rapidly falling ground-water levels in the sandstone aquifer indicate that water supply will not be able to keep pace with development.

OBJECTIVE: In southeast Wisconsin there is a need to construct a three-dimensional ground-water model to address circulation within the shallow and deep aquifer systems in the presence of intense pumping for water supply. The overall aims of the project are to (1) determine essential hydrogeologic parameters of the regional aquifers to permit accurate simulation of regional flows and allow better understanding of the communication between shallow and deep systems; (2) investigate flow paths under different use scenarios for purposes of delineating capture zones and wellhead protection areas, evaluating well interference, and examining ground-water/surface-water connections; and (3) permit optimization of future well placement and pumping schedules by use of submodels.

\begin{abstract}
APPROACH: The water utilities need information from the USGS to decide on a regional strategy for optimizing water supply. Specifically they need a framework to decide on the spacing, number, and, perhaps most critically, the open interval. A balance is needed between relatively thin shallow aquifers that are potentially subject to surface contamination and the underlying thick sandstone aquifer that suffers from excessive drawdown, increasing salinity, and potential radium influx. Optimization depends on many factors: for example, mapping of recharge areas to the shallow system and the sandstone aquifer, evaluation of the exchange between the two systems across units such as the Maquoketa Shale, and a better understanding of the stratigraphy in the deep sandstone aquifer. A regional three-dimensional model will serve as the platform for integrating these factors. It will also serve as the tool for simulating optimization scenarios.
\end{abstract}

PROGRESS (July 1999 to June 2000): The tasks performed this year were all directed toward construction of the regional model. Tasks included (1) assembly of an "Oracle" database for well and hydrostratigraphic data related to the groundwater model; (2) interpretation of Wisconsin and Illinois geophysical logs for the purposes of identifying units and estimating aquifer properties such as hydraulic conductivity and vertical anisotropy; (3) interpretation of 'specific capacity results to map lateral variations in hydraulic conductivity for hydrostratigrahic units, (4) interpretation of cable-tool drilling records to better understand vertical changes in ground-water head between units, (5) compilation of historical water-use information, (6) down-hole geophysics conducted at a Waukesha supply well to define changing properties of the sandstone aquifer with depth, and (7) initial model construction to properly correlate hydrostratigraphic units with model layers and test the effect of layering on the response to pumping.
COOPERATOR:

Wisconsin Geological and

Natural History Survey

LOCATION:

Southeast Wisconsin

PROJECT CHIEF:

Daniel Feinstein

PERIOD OF PROJECT:

February 1998 to September 2003

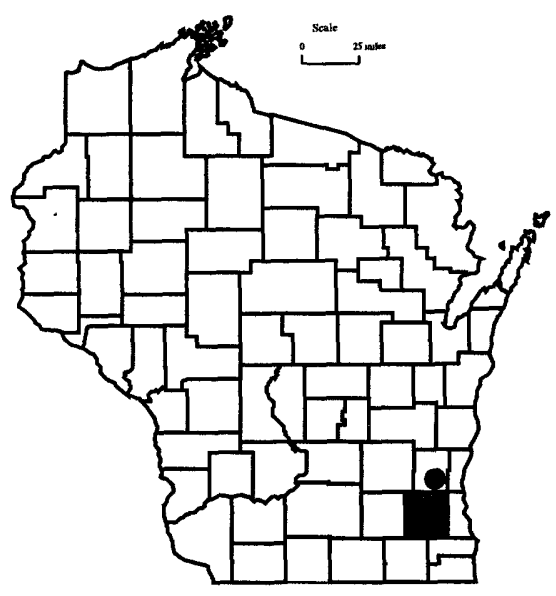


PLANS (July 2000 to June 2001): During the second year of the project, the major tasks undertaken by the USGS will include (1) definition of key inputs to the regional model such as recharge zones; bedrock valleys, and discharge streams, (2) final construction of the model fixing the grid, parameter zonation and boundary condition, (3) preliminary calibration to historical water-level data, and (4) formal calibration and sensitivity analysis. 


\section{SALTON SEA SCIENCE SUBCOMMITTEE, WI 20900}

PROBLEM: Environmental conditions at the Salton Sea, a saline lake and important wildlife refuge in southern California, have been deteriorating for many years. Salinity has increased steadily and is now 25 percent higher than that of ocean water. Concentrations of other contaminants have also increased. Lacking any outlet tributary, the water levels and chemistry of the Sea are largely controlled by evaporation and the inflows from agricultural drainage. Major fish and wildlife kills have occurred in recent years. Very little research has been done previously to describe the ecology and environmental stresses of this unique ecosystem.

In late 1997, the Department of Interior initiated a Salton Sea Restoration Project. Following guidelines of the National Environmental Policy Act (NEPA) and the California Environmental Quality Act (CEQA), this project included the establishment of a Salton Sea Science Subcommittee to oversee and coordinate scientific research. The Subcommittee is composed of representatives from various government and local agencies involved in Salton Sea research and management.

OBJECTIVES: The purpose of the Salton Sea Science Subcommittee is to provide scientific evaluations and recommendations required to guide the NEPA/CEQA process to successful mitigation of current degradation of the Salton Sea ecosystem and restoration of environmental, wildlife, recreational, and economic values.

APPROACH: To fulfill its purpose, the functions of the Salton Sea Science Subcommittee are to (1) compile an inventory of current studies and existing scientific information relative to questions associated with proposed alternatives for Salton Sea management; (2) identify current information gaps; (3) frame and prioritize science/information needs and critical time periods for obtaining information relative to decision processes associated with NEPA/CEQA; (4) solicit and evaluate science research proposals; (5) make recommendations to the Research Management Committee for funding priorities; (6) ensure timely transmission and exchange of information obtained from funded studies; (7) evaluate existing Salton Sea ecosystem models and facilitate their enhancement and integration where appropriate; and (8) develop standards for scientific baselines against which changes can be monitored to assess the impacts of management actions.

The executive director, special assistant to the director, and the science coordinator of the Salton Sea Science Subcommittee are located in the Wisconsin District Office. Monthly subcommittee meetings are held in California.
COOPERATOR:

U.S. Geological Survey, Biological Resources Division

\section{LOCATION:}

Salton Sea, California

PROJECT CHIEF: John F. Elder

PERIOD OF PROJECT: February 1998 to September 2000

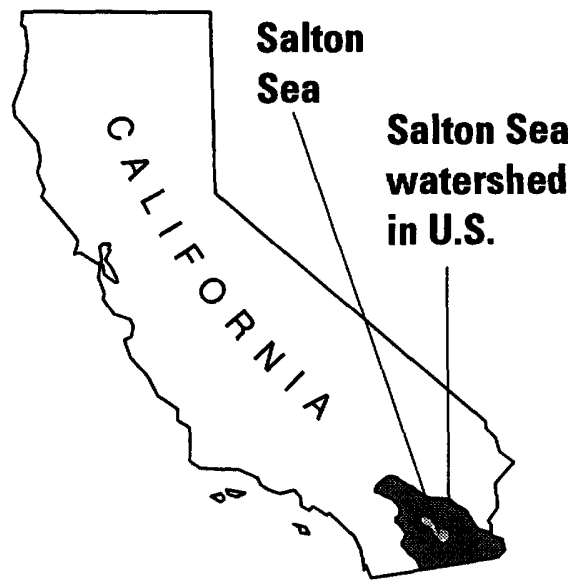


PROGRESS (July 1999 to June 2000): Additional Requests for Proposals (RFPs) were issued to fill remaining research needs in areas of avian diseases, algal toxins and nutrient loading. Following external peer review of proposals, one project for each topic area was funded. Studies of avian diseases and algal toxins began in September, and the nutrient loading study began in early 2000. A Salton Sea Symposium was planned which was held in January 2000. A Salton Sea Strategic Science Plan for supporting continued scientific work to facilitate management was drafted and completed. Drafts of the Environmental Impact Statement/Report prepared by a contractor for the U.S. Bureau of Reclamation was reviewed. The Salton Sea Science Subcommittee completed its assignment and disbanded in December 1999.

PLANS (July 2000 to September 2000): Although the Subcommittee disbanded, the Salton Sea Restoration Project continues, and projects funded under Subcommittee recommendations continue. Coordination and monitoring of project activities will proceed. Manuscripts from work presented at the Salton Sea Symposium are to be reviewed and submitted to Hydrobiologia for special edition publication. Protocols for carrying out work recommended in the Strategic Science Plan will be developed. 


\section{DATABASE APPLICATIONS, WI 21000}

PROBLEM: Natural resources agencies are having difficulty organizing, storing, and distributing their information products using existing resources (staff, hardware, and software).

OBJECTIVE: The purpose of this project is to provide our cooperators, the USGS, and other agencies with modern alternatives to their existing information technology resources. The objective is to provide our customers with high-quality data processing methods.

\begin{abstract}
APPROACH: The Database Unit in the Wisconsin District is dedicated to the design, development, and deployment of relational database systems geared to address water resources-related data management problems being faced by our cooperators and other federal agencies. Systems developed are centered on Oracle Corporation technology at this time. The focus is on fewer but larger projects in terms of workload and funding levels. The unit provides an alternative resource for these customers to compliment their inhouse information technology staff and/or outside consultants.
\end{abstract}

The Unit attempts to apply cutting-edge technology in the resolution of the data management problems, within the limitations of available funding and staff. It is assumed that lower-end technology or approaches are more widely available to our customers already, and that we will provide a more valuable service by making higherend solutions obtainable. The study has six subprojects.

PROGRESS (July 1999 to June 2000): Three new servers were purchased to support the increasing resource demands of the unit. Support licensing was renewed for all software, and additional purchases of software for Oracle Reports, Jdeveloper, and Spatial were made. Map Info Java Extreme was purchased to support development of deployment methods for presenting maps onto the web. This product will replace the Formida tool we tried last year.

Two new programmers were hired, and one programmer left the unit. Three programmers were sent to a database-modeling course in January. The unit now consists of eight full or part-time programmers.

Subproject 21001: Data from the STORET legacy system was retrieved from USEPA (Joyce Boyd, 2/00) after the legacy system was frozen to new data. STORET legacy data will be loaded into the MWDI database after determination has been made of what type of data is represented at each site through USEPA (Dan Parker, $4 / 00)$. Scripts to load data into database have been compiled $(3 / 00)$. Retrieval of data from the NWIS system is on hold until updates from districts to the site file information have been made (Colleen Babcock, 2/29/00). The MWDI queriable website (URL: http:// orcddwimdn.er.usgs.gov/mwdi/mwdi.home) is accessible to the public and linked from the USEPA "Surf your watershed" web pages. Input forms allowing other agencies to enter information for water monitoring sites have been created but may require minor changes before being put on-line (URL: http://orcddwimdn.er.usgs.gov/mwdi/mwdi.forms).
COOPERATOR:

City of Milwaukee

U.S. Environmental Protection

Agency (USEPA)

U.S. Geological Survey,

CAPP and WRD

Wisconsin Department of Natural Resources (WDNR)

LOCATION:

United States

PROJECT CHIEF:

Harry House

PERIOD OF PROJECT: July 1998-Continuing 
Subproject 21002: There have been two planning meetings to outline rollout strategy for the rest of fiscal year 2000 , and on into fiscal year 2001. A preliminary database design to support all USGS publications metadata and content has been created. A preliminary $\mathrm{pl} / \mathrm{sql}$ web program has been written to allow users to search for publications using Oracle Intermedia technology.

Subproject 21003: Plans were written to load data from staging to warehouse database. Query tool set up for cooperator to be able to create data queries specific to the cooperator's needs. A public interface website (English and Spanish) including daily beach water quality and meteorological data, web camera images, Milwaukee Health Department publications, pollution prevention information, sampling site maps, links to related websites, cooperator information, counter were made. Technical interface website was completed (also partially accessible to the general public) and includes queries from database, all data, forms to enter new data (accessible only to Milwaukee and Racine Health departments).

Subproject 21004: The software for the public interface has been chosen and development has begun for that deployment. The software will enable national NAWQA users to develop queries suitable for the public using preexisting software and subsequently "post" them on the Internet. In addition to the public interface development, database maintenance, NAWQA planning database adjustments, and user support have all occurred in this session. The database server that serves out the NAWQA data has been relocated to the District Office from CAPP to foster database tuning and in anticipation of the network upgrade.

Subproject 21005: A series of meetings was held with the administrators of the 6 legacy databases and other data management personnel at WDNR to identify which WDNR data should be entered into the new database. Documentation for data in the 6 legacy systems was obtained and user requirements for the new system were discussed. A third-normal design for the new database has been completed, and reference tables are being populated. The WDNR Biology Database Project website has been created and a number of data input forms and reports are now mounted on the site. Data reporting capabilities include parameterized dynamic database query, customized reports, and downloading of data in an Excel format. When necessary, data are protected by passwords and assigned privileges.

Subproject 21006: the EMMI and EMSD legacy databases were received, and the data structure from these databases loaded into Oracle. A fact sheet on NEMI was completed and will be distributed at the National Water Quality Monitoring Conference in April. User requirements are being gathered through discussions with members of the MDCB. A preliminary third-normal design for the NEMI database has been completed. Numerous meetings have been held via conference call to discuss database design and fields that should be included in NEMI.

PLANS (July 2000 to June 2001): Additional purchases of servers are planned to further enhance our hardware infrastructure. Expanded licensing levels will be pursued for existing and additional Oracle software products. The level of licensing for the Map Info products will be expanded. A significant increase in network bandwidth out of the district is planned, at either a full T1 level, or even a direct internet connection.

The unit is pursuing additional projects for fiscal year 2001. These include a multiagency effort in Southeast Wisconsin, expanded duties with the WDNR, a collaboration with the University of New Hampshire and NSF for a Russian hydrology database, among others. All current projects are expected to continue, with the exception of the 21003 subproject with the City of Milwaukee (Empact program).

Subproject 21001: After site type has been determined, STORET data will be loaded into database. NWIS data will be retrieved and loaded after districts have made site file updates. Periodic uploads of new STORET and NWIS data will be made. Input forms will be linked to the web page. If more funding is provided by EPA, plans include the development of a geospatial interface into the existing data, addition of data from new agencies, and a new set of data from EPA to track research-oriented datasets not presently allowed to be stored in the STORET system.

Subproject 21002: The database design will be fine-tuned and loaded with about 100,000 bibliographic citations from CAPP. Once the new data is in, work will proceed on improving the web interface program. Bureau of Land Management has recently inquired as to the possibility of adding a number of non-USGS publications to the publications database, and initial approval has been obtained. Work on this could begin this fiscal year.

Subproject 21003: Addition to database will be completed to hold sonde data. Plans will be written to load sonde data into staging and data warehouse. Modifications to website (cosmetic updates) will be made. Data will be made available to public in easier queriable format. We will insure that webcam images are updating automatically. In addition to what is discussed in signed project agreement, we may use EMPACT as a test project for geospatial database linking. Future EMPACT meetings will be attended. We will discuss plans for fiscal year 2001 with cooperatormaintaining or moving database and webpage. 
Subproject 21004: The public interface should be in production. A prototype mapping application, which displays query output on to a map, should be in progress. The next reload of the database should be complete. The loading progress should be rewritten in ORACLE data warehouse builder and more automation of the loading routines should be done. The planning database may be re-engineered.

Subproject 21005: The WDNR Biology Database will be initially sited at USGS offices in Middleton, Wisconsin, during testing and deployment, with plans to export the database to WDNR facilities in Madison, Wisconsin, in the near future. After reference tables are populated, forms will be prepared to enable input and retrieval of WDNR field data over the internet. It is expected that forms development will be an iterative process as user requirements are refined. As the database becomes populated with new data and also historical data, performance of the transactional database will be evaluated. If data reporting performance is inadequate, a system to deploy a denormalized version (star schema) and associated datamovement programming will be developed and implemented.

Subproject 21006: The third-normal form of the database will be refined. EPA contractors will select 100 methods to load in the prototype database, and refined business rules and user requirements will be developed based on the normalized data in these methods. A web interface into the database will be created in webdb, and users will be able to query data based on text-indexing generated by Oracle Intermedia Text technology. 


\section{WOLF RIVER SEDIMENT, WI 21100}

\section{COOPERATOR:}

\section{Menominee Indian Tribe of Wisconsin}

\section{LOCATION:}

Menominee Indian Reservation

\section{PROJECT CHIEF:}

Faith A. Fitzpatrick

\section{PERIOD OF PROJECT:}

October 1998 to September 2001

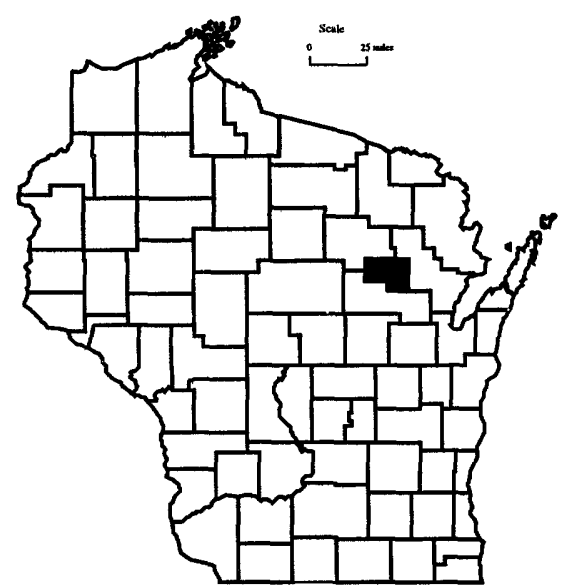

PROBLEM: Protection of the pristine quality of the Wolf River in northeastern Wisconsin is of primary importance to the Menominee Indian Tribe of Wisconsin. Long-term historical data on streamflow, sedimentation rates, and trace element concentrations in sediment are needed to place current and future water-quality conditions as modified by human activity in perspective with natural conditions.

OBJECTIVE: The objectives are to (1) identify natural and historical concentrations of trace elements in streambed, floodplain, and backwater sediments of the Wolf River from Keshena Falls to Balsam Row Dam; (2) identify range of historical (150+ years) variability of flooding and sedimentation characteristics along the same reach of the Wolf River; (3) identify major factors affecting stream sedimentation and flooding characteristics-geologic/natural vs. land-use effects; and (4) investigate possibility of expanding study on the Wolf River upstream of Keshena Falls or on selected tributaries to the Wolf River.

APPROACH: Two long-term streamflow records will be examined for changes in peak flows (magnitude and frequency) and seasonality of flows on the Wolf River-Wolf River at Keshena Falls and Wolf River near Shawano. These streamflow records will be compared with the streamflow records from the Langlade gaging station. Government Land Office Survey notes will be examined and compared to current conditions at section line crossings. Thickness, texture, and stratigraphy of sediment in cores from the floodplain, backwater areas, and modern channel will be examined. Approximately six cores will be collected from approximately eight transects surveyed along the study reach. Selected core samples (approximately 24 samples) for particle size, trace elements, and radiometric dating will be sent to U.S. Geological Survey laboratories.

PROGRESS (July 1999 to June 2000): Cores were collected from channel, backwater, and flood-plain environments. Channel/valley cross sections were surveyed at core locations. Streamflow trends analyses and laboratory analyses were completed.

PLANS (July 2000 to June 2001): Water-resources investigations report titled "Historical trends in streamflow, sedimentation rates, and sediment trace-element concentrations associated with the Wolf River, Keshena Falls to Balsam Row Dam" will be written and published. 


\section{ST. CROIX NATIONAL SCENIC RIVERWAY - NUTRIENT AND SEDIMENT LOADING AND LONG-TERM WATER-QUALITY MONITORING, WI 21200, 21202}

PROBLEM: The St. Croix National Scenic Riverway (NSR) contains more than 60 state and federally listed endangered and threatened species, indicating that it provides one of the few remaining relatively well-preserved and biologically diverse aquatic environments in the region. The Riverway has a very active management and scientific community and a rich research history. Although the water quality is generally considered to be good in the upper St. Croix and Namekagon Rivers, activities in the tributaries and their watershed are affecting the overall health of the St. Croix NSR. In the Lower St. Croix, including Lake St. Croix, nutrient levels are elevated. Recreational and developmental pressures are intensifying in the watershed. Recreational use has doubled since 1973 to nearly one million visitors yearly. Due to its proximity to the Minneapolis/St. Paul metropolitan area, the Riverway will continue to experience increased use and developmental pressure from population growth in the counties adjacent to the Riverway.

OBJECTIVE: The objectives are to collect nutrient, sediment, and flow data from tributaries that are significant contributors or have specific land-use or environmental factors thought to be related to sediment and nutrient yields and provide consistent, long-term water-quality monitoring at key sites on the St. Croix River to develop a long-term database to use to detect changes and protect the water resources of the St. Croix River.

APPROACH: 21200: USGS/NPS/Minnesota-Wisconsin Boundary Area Commission-From October 1998 through September 1999, the USGS continuously monitored streamflow, and collected sediment and nutrient samples at 2 tributaries in the Upper St. Croix Falls basin: Trade and Wood Rivers. Nutrients and sediment loads and yields at these sites are being calculated.

21200: USGS/WDNR Coop-The USGS, as part of a cooperative agreement with the WDNR, St. Croix County, and Trout Unlimited, continuously monitored streamflow, and collected sediment and nutrient samples at three major tributaries feeding directly into Lake St. Croix in the lower portion of the St. Croix basin: Kinnickinnic River, Apple River, and Willow River. USGS personnel are doing similar work in the upper basin. Observers near the sites sampled monthly on a 2-week offset from USGS and at several storms using a dip sample for total phosphorus. This data will be used to develop an improved estimate of daily loads directly into the lake. Nutrients and sediment loads and yields at these sites are being calculated.

21202: USGS/NPS Long-Term Monitoring-The USGS has developed a cooperative agreement with the Minnesota-Wisconsin Boundary Area Commission and the NPS to continuously monitor streamflow at the St. Croix River near Danbury and the Namekagon River near Leonards. Additionally, the project funds collection of monthly plus four storm event samples for nutrients, sediments, major ions, and organic carbon sampling at two mainstem sites: St. Croix River at St. Croix Falls and St. Croix River at Danbury.
COOPERATOR:

National Park Service

Minnesota-Wisconsin Boundary

Area Commission

St. Croix County Land

Conservation Department

LOCATION:

St. Croix National Scenic

Riverway

PROJECT CHIEF:

Bernard N. Lenz

PERIOD OF PROJECT:

October 1998 to September 2000

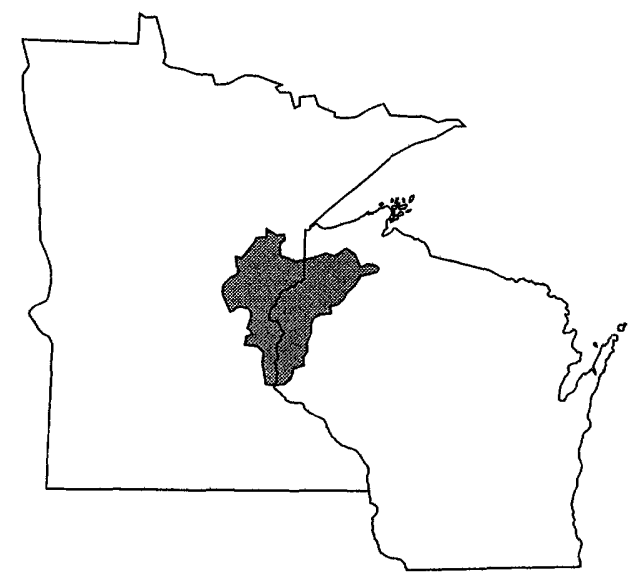


Annual loads will be calculated at all monitored tributaries using the daily flow record, nutrient and sediment concentrations and the USGS loads calculation program ESTIMATOR. This data will be used for additional analysis (see WI 21300). Water-resource managers and park officials can use the results of this study to plan, study, implement, or protect water resources in the St. Croix Basin.

PROGRESS (July 1999 to June 2000): Continuous streamflow monitoring and monthly water-quality sampling was completed at the tributaries and main-stem sites. Snowmelt runoff and a spring storm event have been sampled. Calculation of nutrient and sediment loading and yields has begun. Semiannual progress reports are being supplied to the NPS throughout the project. Many new partnerships with scientists and agencies working in the St. Croix Basin have been developed. A heightened awareness of nutrient and sediment loading and these new relationships should lead to continued scientific interest and study in the St. Croix Scenic Riverway.

PLANS (July 2000 to September 2000): A waterresources investigation report will be written in water year 2000 using this data. This report will give calculated sediment and nutrient loads on the monitored tributaries and main-stem sites. Additional analysis funded by another project (WI 21300) will discuss relations between environmental factors and loads and these relations will be used to estimate nutrient loads on the unmonitored tributaries. Sediment and nutrient loading estimates throughout the basin will be presented in the report. 


\section{ST. CROIX NATIONAL SCENIC RIVERWAY - NUTRIENT AND SEDIMENT LOADING, WATER-QUALITY MONITORING AND ASSESSMENT PARTNERSHIP, WI 21300}

PROBLEM: The St. Croix National Scenic Riverway (NSR) contains more than 60 state and federally listed endangered and threatened species, indicating that it provides one of the few remaining relatively well-preserved and biologically diverse aquatic environments in the region. The Riverway has a very active management and scientific community and a rich research history. Although the water quality is generally considered to be good in the upper St. Croix and Namekagon Rivers, activities in the tributaries and their watershed are affecting the overall health of the St. Croix NSR. In the Lower St. Croix, including Lake St. Croix, nutrient levels are elevated. Recreational and developmental pressures are intensifying in the watershed. Recreational use has doubled since 1973 to nearly one million visitors yearly. Due to its proximity to the Minneapolis/St. Paul metropolitan area, the Riverway will continue to experience increased use and developmental pressure from population growth in the counties adjacent to the Riverway.

OBJECTIVE: Objectives are to (1) examine existing data to determine areas of significant sediment and nutrient contributions in the St. Croix River Basin; (2) collect nutrient, sediment, and flow data from tributaries that are significant contributors or have specific land-use or environmental factors thought to be related to sediment and nutrient yields; (3) determine relations of environmental factors and land use to sediment and nutrient yields in the St. Croix River Basin; (4) predict sediment and nutrient yields in the unmonitored portion of the basin using known land use and environmental factors and their relations to sediment and nutrient yields determined in this study to estimate nutrient and sediment budgets for the entire St. Croix River Basin; and (5) provide model inputs to the Minnesota Pollution Control Agency (MPCA) and the WDNR for a FLUX BATHTUB model of Lake St. Croix and the St. Croix Reservoir at St. Croix Falls.

APPROACH: Sediment, nutrient and flow data were collected at tributaries to the St Croix River and annual loads were calculated using the USGS loads calculation program ESTIMATOR. Point source loading data was obtained. Annual yields will be calculated by dividing annual loads by basin drainage area. Environmental factors such as land use, soils, and geology will have been derived for monitored and unmonitored tributary subbasin from existing GIS coverages and databases. The multivariate statistical procedures will be used to determine environmental factors with the most significant relation to nonpoint-source sediment and nutrient yields in the monitored portions of the basin. Multivariate regressions between yields and environmental factors will be developed and used to estimate loads in the unmonitored portions of the basin. Errors of estimation will be included. The calculated tributary loads, estimated tributary loads and calculated loads data from the mainstem sites will provide a temporally consistent snapshot of nutrient and sediment loading in the St. Croix River watershed.
COOPERATOR:

National Park Service

LOCATION:

St. Croix National Scenic Riverway

PROJECT CHIEF:

Bernard N. Lenz

PERIOD OF PROJECT:

October 1998 to September 2000

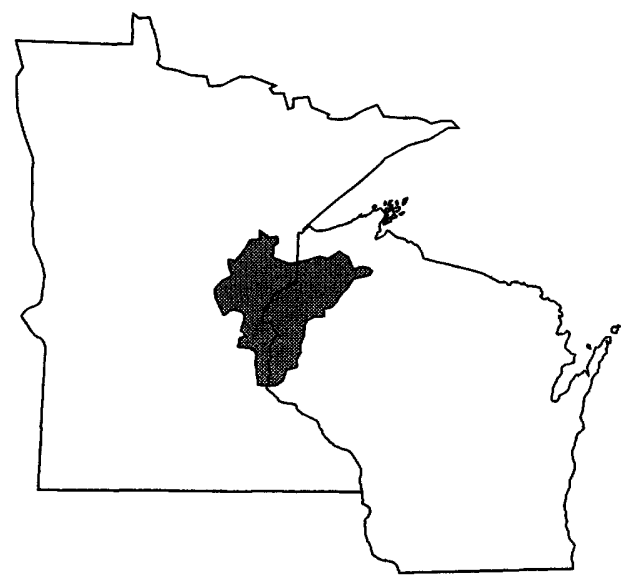


Water resource managers and park officials can use the results of this study to plan, study, implement, or protect water resources in the St. Croix Basin.

PROGRESS (July 1999 to June 2000): Continuous-flow monitoring and water-quality sampling were completed and loads calculated at USGS monitored sites. Additionally, MPCA and Metropolitan Council have data similar to the USGS data at sites above St. Croix Falls (Kettle, Snake, and Sunrise Rivers; and Browns, Valley, and Silver Creek, respectively). Loads are being calculated from this data as well. Environmental factors such as soils, land use/land cover, and geology has been determined by tributary sub-basin from existing GIS coverages. Semiannual progress reports have been supplied to the Park Service.

The MPCA, WDNR, and Metropolitan Council Environment Services contributed additional money and/or time to sample Lake St. Croix and the Indianhead Reservoir above the St. Croix Falls power plant during the 1999 water year. They have begun using FLUX and BATHTUB models to look at the nutrient and sediment in these impoundments. USGS tributary data is an essential part of their model inputs.

PLANS (July 2000 to September 2000): Analysis will be performed and a water-resources investigation report will be written. This report will give calculated sediment and nutrient loads on the monitored tributaries and main-stem sites. It will discuss relations between environmental factors and loads and these relations will be used to estimate nutrient loads on the unmonitored tributaries. Estimated sediment and nutrient loading by tributary for the entire St. Croix River basin will be presented in the report. The multiagency correspondence and meetings will continue in order to coordinate the projects, share ideas, and disseminate results. Talks on the study will be given at the St. Croix River Research Rendezvous and other appropriate meetings or conferences. 


\section{WHITTLESEY CREEK HYDROLOGY STUDY, WI 21500}

PROBLEM: Whittlesey Creek is considered an Outstanding Resource Water and Valued Lake Superior Ecosystem Member. This small watershed serves as spawning ground for 35 percent of Wisconsin's coho salmon population because of its consistent base flow and good water quality. However, like many Wisconsin tributaries to Lake Superior, aquatic habitat in Whittlesey Creek is possibly degraded because of accelerated runoff and associated sedimentation problems. In addition, the sources for the abundant baseflow in Whittlesey Creek are not very well understood. Recently, the mouth of Whittlesey Creek has been proposed as a National refuge for the re-establishment of Coaster Brook Trout. A hydrological analysis of streamflow in Whittlesey Creek is needed to identify potential present and future land-cover impacts on baseflow and flooding characteristics of the creek.

OBJECTIVE: Objectives are to (1) quantify current streamflow characteristics for Whittlesey Creek floods, base flow, and seasonal fluctuations, (2) quantify contributions of runoff and ground water to streamflow, (3) identify ground-water recharge and discharge areas for Whittlesey Creek (identify contributions from glacial deposits vs. sandstone bedrock aquifers), (4) identify pre-settlement hydrologic conditions, (5) quantify how current land-cover characteristics affect flood and base-flow characteristics, (6) predict how future changes in land cover affect floods and base flow in Whittlesey Creek and (7) identify areas of the basin that contribute the most to flooding problems.

APPROACH: This approach uses an event-based rainfall/runoff model (HEC-1; U.S. Army Corps of Engineers, 1990) and a USGS ground-water model (MODFLOW; McDonald and Harbaugh, 1998) to quantify base flow and flooding characteristics of Whittlesey Creek. Hydrologic field data also will be collected to help refine and calibrate the models. The proposed study would start in April 1999 with installation and operation of a streamflow and rainfall gaging station near the mouth of Whittlesey Creek and a survey of base-flow conditions (seepage run). In FY 2000, additional field data would be collected for the rainfall/runoff and ground-water models, GIS data for the rainfall/runoff model will be gathered, and the models will be run and calibrated. In FY 2001, a report on the modeling results will be written and published

PROGRESS (July 1999 to June 2000): Gaging station on Whittlesey Creek was maintained and operated. Base-flow surveys were conducted in August 1999 and April 2000. Five stage recorders were installed in March 2000. Ground-water and rainfall/runoff models were started.

PLANS (July 2000 to June 2001): Plans are to conduct baseflow survey in August 2000, install two monitoring wells, maintain gaging station and stage recorders and update ground-water and rainfall/runoff models.
COOPERATOR:

Bayfield County

LOCATION:

Bayfield County

PROJECT CHIEF:

Faith Fitzpatrick

PERIOD OF PROJECT:

May 1999 to September 2001

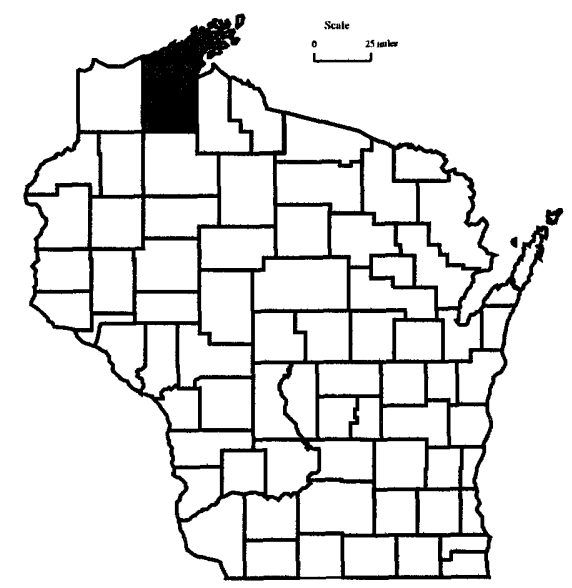




\section{SOURCES OF CRYPTOSPORIDIUM IN WATERSHEDS, WI 21600}

\author{
COOPERATOR: \\ Wisconsin State Laboratory of \\ Hygiene
}

LOCATION:

Southeast Wisconsin

PROJECT CHIEF:

Steve Corsi

Robert Waschbusch

PERIOD OF PROJECT: October 1999 to April 2002

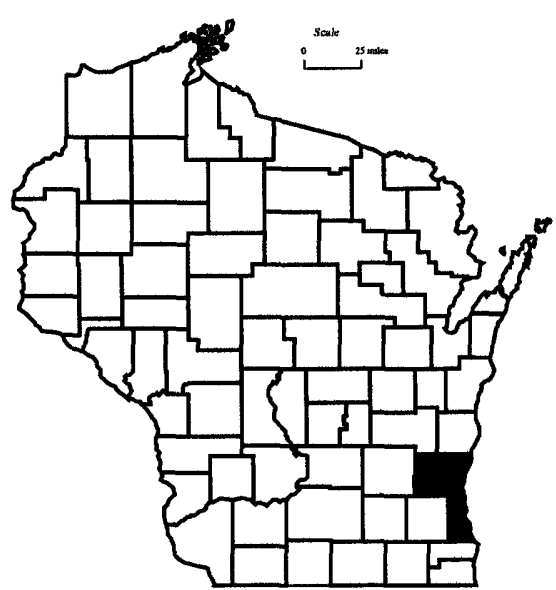

PROBLEM: For the past 75 years, the water supply industry has enjoyed an excellent track record of providing safe, potable water to the public. As a result, the industry has achieved a high level of consumer confidence in tap water. This success has been possible through an emphasis on continuous improvement in both water-treatment technology and source-water protection. Despite this effort, recent well-publicized waterborne disease outbreaks of cryptosporidiosis involving large numbers of ill people and some deaths have been attributed to possible treatment deficiencies linked with source-water contamination. Recent studies have suggested that the Milwaukee outbreak of 1993 was caused by a "human only" genotype which would point to poorly treated human waste as a possible source of the outbreak. It is extremely important that both the waste-water industry and the drinking water industry have the best information available to respond to both water-borne disease issues and legislative issues in an effective manner. Understanding the occurrence and variability of cryptosporidium in source water is critical to the production of a safe drinking water supply. Essential to this understanding is the ability to characterize potential sources of cryptosporidium and predict their response to hydrologic and climatologic events.

OBJECTIVE: The goals of the research outlined in this proposal are to define the relative magnitude and contributions of cryptosporidium from major sources defined by land use and wastewater discharges on an annual basis, to characterize contributions of each source by factors such as hydrograph timing, climatic effects, and seasonal variations, and to compare and integrate the resulting data with existing data on cryptosporidium.

APPROACH: Two subwatersheds will be selected for monitoring the entire project duration. One of these basins will be primarily agricultural land use and the other will be primarily urban land use. In addition to these two subwatersheds, three waste-water treatment plant discharges representing different treatment technologies and/ or flow levels and one combined sewer overflow (CSO) will be monitored for approximately 6 months each. Both fixed interval and weather event samples will be collected from all sites. The sample results will be used to determine cryptosporidium magnitude and variability. These data will be used along with flow data to calculate event and annual loads at the sites. Other data will also be collected including precipitation, water temperature, dissolved oxygen, turbidity, conductance and also land-use data in a GIS system. The data and tools resulting from this project will enable managers to better understand and deal with the sources of cryptosporidium in their watersheds.

PROGRESS (October 1999 to June 2000): The agricultural and urban basins and the first publicly-owned treatment works (POTW) have been selected and instrumented. Samples have been collected from two runoff events and six fixed intervals at all three sites. 
PLANS (July 2000 to June 2001): Runoff event sampling and fixed interval sampling will continue through December 2001 at the agricultural and urban sites. One more event sample will be collected at the first POTW site and then the equipment will be moved to the next POTW site. 


\section{HISTORICAL ECOSYSTEM RECONSTRUCTION AND POTENTIAL IDENTIFICATION OF EFFECTS OF PAST ECOSYSTEM PERTURBATIONS IN LAC COURTE OREILLES, WI 21700}

COOPERATOR:

Lac Courte Oreilles Tribe

LOCATION:

Lac Courte Oreilles Reservation, Sawyer County

PROJECT CHIEF:

Faith Fitzpatrick

\section{PERIOD OF PROJECT: \\ October 1999 to September 2001}

PROBLEM: There has been a potential increase in nutrient inputs and enhanced eutrophication in Musky Bay, Lac Courte Oreilles, Wisconsin in the last few decades. Historically, the Bay contained wild rice beds and was a major spawning ground for muskellunge, which make up a large portion of the Lac Courte Oreilles Tribe's diet. Currently, there are no wild rice beds in the Bay, organic muck covers the muskellunge spawning beds, and the bay is choked with macrophytes and algae. The Lac Courte Oreilles Tribe is interested in determining changes in historical nutrient inputs to Musky Bay, determining the source of the nutrients, and comparing these findings to historical nutrient inputs in other parts of Lac Courte Oreilles.

OBJECTIVE: The main objective is to reconstruct the ecosystem history of Musky Bay and an additional site within Lac Courte Oreilles with special emphasis on possible effects of cranberry farming and shoreline development using the sediment record. The principal focus is on the nutrient history (input and burial rates) that reflects management practices and possible watershed degradation. The modeled nutrient history will be interpreted in concert with reconstructed algal (mainly diatoms) communities preserved in the sediments. Another focus is to search for possible cranberry farming signatures including sulfur, uranium, and potassium associated with fertilizers, and copper associated with pesticides. Biogenic silica profiles will provide complimentary data for algal community reconstructions. The sediment record likely preserves observable trends in nutrient biogeochemical cycling and ecosystem character over the last few hundred years, a time that includes a background period and the period of cranberry farming.

APPROACH: Several cores from Musky Bay and additional sites on the lake will be collected in the fall or winter of 1999/2000. Dates and sedimentation rates will be calculated for 20 increments in the Musky Bay core (15 increments from an additional core) from analyses of ${ }^{210} \mathrm{~Pb},{ }^{226} \mathrm{Ra}$, and ${ }^{137} \mathrm{Cs}$ using direct gamma counting (Schelske et al., 1994). Total organic carbon and nutrient (nitrogen, phosphorus, biogenic silica) input and burial rates will be calculated from dated sediment by combining measured concentrations of these nutrients and mass sediment accumulation rates. Biogenic silica profiles will be used as supporting evidence for diatom reconstructions and as an indicator of species shifts (largely from diatoms to non-siliceous algae) in response to increased nutrient inputs. Diatom assemblages will be examined for 20 increments in the Musky Bay core (15 increments from the additional core). Plant macrofossils will be examined to directly reconstruct changes in wild rice beds to supplement littoral community changes suggested by the diatom assemblage. Macrofossils will be identified. Forty-two geochemical parameters will also be measured in these cores using inductively coupled plasma-mass spectrometry (ICP-MS). Bulk density and porosity of samples will be determined to adequately measure sedimentation rates and mass accumulation rates. A water-resources investigations report will be completed by September 2001 . 
PROGRESS (October 1999 to June 2000): Three cores were collected from Musky Bay, one core from the deepest part of the lake, one core from Northeast (Barbertown Bay), and one core from Stuckey Bay. Cores were subsampled and samples from the Musky Bay and Barbertown Bay were freeze dried. Samples were submitted for $\mathrm{Pb} / \mathrm{Cs}$ dating.

PLANS (July 2000 to June 2001): Remainder of samples will be submitted after analyses of $\mathrm{Pb} / \mathrm{Cs}$ results confirm that bioturbation is not a problem. Report will be written. 


\section{THE EFFECT OF NEAR-SHORE DEVELOPMENT ON CONSTITUENT LOADING TO LAKES IN NORTHERN WISCONSIN, WI 21800}

COOPERATOR:

Wisconsin Department of Natural Resources

LOCATION:

Vilas and Forest Counties

PROJECT CHIEFS:

David J. Graczyk

Randall J. Hunt

PERIOD OF PROJECT: October 1999 to September 2001
PROBLEM: Additions of nutrients, pesticides and sediment from near-shore developments to lakes may seriously degrade lake water quality. Shoreline-zoning regulations such as required setbacks, cutting restrictions and buffers between the lake and development have been developed in the hope that these requirements can mitigate the effects of sediment and nutrient runoff.

Previous studies have estimated the amount of these loadings from the lake watershed but few studies have determined the processes and pathways in which these constituents are delivered to the lake at a site-specific scale (e.g., one-acre parcel). The effectiveness of buffers or cutting restrictions on reducing the amount of chemical constituent loads and sediment has yet to be demonstrated.

OBJECTIVE: The objectives of the study are to (1) estimate the quantity of surface-water runoff and ground water that flows into a lake from developed and undeveloped lands and (2) determine the quality of surface-water runoff and ground water that flows into a lake from developed and undeveloped lands.

APPROACH: Effects of shoreline development on water and nutrient loading will be assessed using a paired approach. The comparison will focus on developed and undeveloped sites on four lakes in Vilas and Forest Counties in northern Wisconsin. Developed sites may include runoff from lawns, driveways, sidewalks and roofs; undeveloped sites consist of mostly immature woods having woody and non-woody vegetation and relatively undisturbed ground. Both surface-water runoff and ground-water components will be characterized where appropriate.

Sites were divided into those where the lakes have ground-water inflow and those that do not. Those that had ground-water inflow will be instrumented to characterize the ground- and surface-water components. Sites with ground-water flow away from the lake will be instrumented to characterize surface-water components only. Each site will be surveyed and a detailed map will be prepared to determine the areas that contribute to surface runoff.

A tipping bucket rain gage will be installed at each site. Precipitation will be measured during the non-freezing portion of the year. Precipitation from a nearby National Weather Service gage will be used during freezing periods.

Surface-water runoff will be measured by using two types of monitors depending on the site. An automatic collection monitor will be installed at four sites. A passive collection monitor will be installed at two sites. The quality of surface water will be determined from analyses of the runoff collected by both automated and non-automated systems. 
Ground-water flow will be monitored by the installation of piezometer nests. The nests will be distributed along the topographic gradient. The most down-gradient nest will be installed adjacent to the lakeshore. The quality of ground water will be determined from a subset of water table wells and piezometers located at the nest sites. In addition, the quality of ground water that discharges to the lake will be characterized using seepage meters and pore-water diffusion equilibrators.

All surface- and ground-water samples will be analyzed for total dissolved phosphorus, total phosphorus, ammonia nitrogen, nitrate and nitrite nitrogen and total Kjeldahl nitrogen. Approximately seven surface-water samples per site will be collected and 5-10 ground-water samples will be collected. The Wisconsin State Laboratory of Hygiene will analyze all samples.

PROGRESS (October 1999 to June 2000): Sites were selected for study and five automated surface-water runoff data-collection sites were installed. These sites include three lawn and two woodland uses. Non-automated samplers at five woods and one lawn site were installed. Five ground-water data-collection systems were installed. Five tipping-bucket rain gages were also installed. Seven surface-water samples were collected. A detailed topographic map was prepared for each site.

PLANS (July 2000 to June 2001): Samples will be collected and analyzed at selected ground-water wells. Samples will be collected and analyzed at the surface-water data-collection sites. Seepage meters and pore-water equilibrators will be installed and waterquality samples will be collected. All water-quality data will be summarized and published in the annual report "Water Resources Data-Wisconsin, 2000". 


\section{WISCONSIN DISTRICT PUBLICATIONS}

The reports listed below are a partial list of reports prepared by the Wisconsin District in cooperation with other agencies since 1948. The list contains reports that are relevant and contribute significantly to understanding the hydrology of Wisconsin's water resources.

The reports published in a U.S. Geological Survey series are for sale by the U.S. Geological Survey, Box 25286, Federal Center, Denver, CO 80225. Prepayment is required. Remittance should be sent by check or money order payable to the U.S. Geological Survey. Prices can be obtained by writing to the above address or by calling 1-888-ASK-USGS. Copies of reports published by the University of Wisconsin, Geological and Natural History Survey, can be obtained from their office at 3817 Mineral Point Road, Madison, WI 53705.

\section{WATER-SUPPLY PAPERS}

Kammerer, P.A., Jr., and Krug, W.R., 1993, Wisconsin stream water quality, in U.S. Geological Survey, National water summary 1990-91-Hydrologic events and stream water quality: U.S. Geological Survey Water-Supply Paper 2400, p. 561-568.

Melcher, N.B., and Walker, J.F., 1992, Evaluation of selected methods for determining streamflow during periods of ice effect: U.S. Geological Survey Water-Supply Paper 2378, 47 p.

U.S. Geological Survey, 1991, National water summary 1988-89Hydrologic Events and Floods and Droughts: U.S. Geological Survey Water-Supply Paper 2375, $591 \mathrm{p}$.

U.S. Geological Survey, 1990, National water summary 1987Hydrologic events and water supply and use: U.S. Geological Survey Water-Supply Paper 2350, 553 p.

1988, National water summary 1986-Hydrologic events, selected water-quality trends, and ground-water quality: U.S. Geological Survey Water-Supply Paper 2325, 569 p.

1986, National water summary 1985-Hydrologic events and surface-water resources: U.S. Geological Survey Water-Supply Paper 2300, $506 \mathrm{p}$.

1985, National water summary 1984—Hydrologic events, selected water-quality trends, and ground-water resources: U.S. Geological Survey Water-Supply Paper 2275, 467 p.

1984, National water summary 1983-Hydrologic events and issues: U.S. Geological Survey Water-Supply Paper 2250, 243 p.

Batten, W.G., and Hindall, S.M., 1980, Sediment deposition in the White River Reservoir, northwestern Wisconsin: U.S. Geological Survey Water-Supply Paper 2069, 30 p.

Sherrill, M.G., 1978, Geology and ground water in Door County, Wisconsin, with emphasis on contamination potential in the Silurian dolomite: U.S. Geological Survey Water-Supply Paper 2047,38 p.

Hurtgen, D.C., 1975, Summary of floods, June 29-30 in southwestern Wisconsin, in Summary of floods in the United States during 1969: U.S. Geological Survey Water-Supply Paper 2030, p. 116119.

Bell, E.A., and Sherrill, M.G., 1974, Water availability in central Wisconsin-an area of near-surface crystalline rock: U.S. Geological Survey Water-Supply Paper 2022, 32 p.

Novitzki, R.P., 1973, Improvement of trout streams in Wisconsin by augmenting low flows with ground water: U.S. Geological Survey Water-Supply Paper 2017, 52 p.
Oakes, Edward, Field, S.J., and Seeger, L.P., 1973, The Pine-Popple River basins-hydrology of a wild river area, northeastern Wisconsin: U.S. Geological Survey Water-Supply Paper 2006, $57 \mathrm{p}$.

Hamilton, L.J., 1971, Water for cranberry culture in the Cranmoor area of central Wisconsin: U.S. Geological Survey Water-Supply Paper 1999-I, 20 p.

Hurtgen, D.C., 1972, Floods of March 27-April 4, 1967, in northwestern and west-central Wisconsin, in summary of floods in the United States during 1967: U.S. Geological Survey WaterSupply Paper $1880-$ C, p. 7-10.

Hutchinson, R.D., 1970, Ground-water resources of Racine and Kenosha Counties, Wisconsin: U.S. Geological Survey WaterSupply Paper $1878,63 \mathrm{p}$.

Olcott, P.G., 1966, Geology and water resources of Winnebago County, Wisconsin: U.S. Geological Survey Water-Supply Paper $1814,61 \mathrm{p}$.

Weeks, E.P., Erickson, D.W., and Holt, C.L.R., Jr., 1965, Hydrology of the Little Plover River basin, Portage County, Wisconsin, and the effects of water-resources development: U.S. Geological Survey Water-Supply Paper 1811, 78 p.

Green, J.H., and Hutchinson, R.D., 1965, Ground-water pumpage and water-level changes in the Milwaukee-Waukesha area, Wisconsin, 1950-61: U.S. Geological Survey Water-Supply Paper 1809-I, $19 \mathrm{p}$.

Summers, W.K., 1965, Geology and ground-water resources of Waushara County, Wisconsin: U.S. Geological Survey WaterSupply Paper 1809-B, 32 p.

Holt, C.L.R., Jr., and Knowles, D.B., 1963, The water situation in Wisconsin in the role of ground water in the national water situation: U.S. Geological Survey Water-Supply Paper 1800, p. $943-$ 960.

Cline, D.R., 1965, Geology and ground-water resources of Dane County, Wisconsin: U.S. Geological Survey Water-Supply Paper $1779-\mathrm{U}, 64 \mathrm{p}$

Holt, C.L.R., Jr., 1965, Geology and water resources of Portage County, Wisconsin: U.S. Geological Survey Water-Supply Paper $1796,77 \mathrm{p}$.

Berkstresser, C.F., Jr., 1964, Ground-water resources of Waupaca County, Wisconsin: U.S. Geological Survey Water-Supply Paper 1669-U, $38 \mathrm{p}$.

Knowles, D.B., 1964, Ground-water conditions in the Green Bay area, Wisconsin, 1950-60: U.S. Geological Survey Water-Supply Paper 1669-J, $37 \mathrm{p}$. 
Cline, D.R., 1963, Hydrology of upper Black Earth Creek basin, Wisconsin, with a section on surface water by M.W. Busby: U.S. Geological Survey Water-Supply Paper 1669-C, 27 p.

Collier, C.R., 1963, Sediment characteristics of small streams in southern Wisconsin, 1954-59: U.S. Geological Survey WaterSupply Paper 1669-B, 34 p.

LeRoux, E.F., 1963, Geology and ground-water resources of Rock County, Wisconsin: U.S. Geological Survey Water-Supply Paper 1619-X, $50 \mathrm{p}$.

Newport, T.G., 1962, Geology and ground-water resources of Fond du Lac County, Wisconsin: U.S. Geological Survey Water-Supply Paper 1604, $52 \mathrm{p}$.

Knowles, D.B., Dreher, F.C., and Whetstone, G.W., 1964, Water resources of the Green Bay area, Wisconsin: U.S. Geological Survey Water-Supply Paper 1499-G, 66 p.

LeRoux, E.F., 1957, Geology and ground-water resources of Outagamie County, Wisconsin: U.S. Geological Survey WaterSupply Paper 1421, $57 \mathrm{p}$.

Harger, A.H., and Drescher, W.J., 1954, Ground-water conditions in south-western Langlade County, Wisconsin: U.S. Geological Survey Water-Supply Paper 1294, $39 \mathrm{p}$.

Foley, F.C., Walton, W.D., and Drescher, W.J., 1953, Ground-water conditions in the Milwaukee-Waukesha area, Wisconsin: U.S. Geological Survey Water-Supply Paper 1229, 96 p.

\section{HYDROLOGIC INVESTIGATIONS ATLASES}

Kammerer, Phil A., Jr., Trotta, Lee C., Krabbenhoft, David P., and Lidwin, R.A., 1998, Geology, ground-water flow, and dissolved-solids concentrations in ground water along hydrogeologic sections through Wisconsin aquifers, U.S. Geological Survey Hydrologic Investigations Atlas, HA-731, 4 sheets.

Gebert, W.A., Graczyk, D.J., and Krug, W.R., 1987, Average annual runoff in the United States, 1951-80: U. S. Geological Survey Hydrologic Investigations Atlas HA-710, 1 sheet.

Hughes, P.E., Hannuksela, J. S., and Danchuk, W.J., 1981, Flood of July 1-5, 1978, on the Kickapoo River, South-western Wisconsin: U.S. Geological Survey Hydrologic Investigations Atlas HA653,7 sheets.

Oakes, E.L., and Cotter, R.D., 1975, Water resources of Wisconsinupper Wisconsin River basin: U.S. Geological Survey Hydrologic Investigations Atlas HA-536, 3 sheets.

Young, H.L., and Skinner, E.L., 1974, Water resources of WisconsinLake Superior basin: U.S. Geological Survey Hydrologic Investigations Atlas HA-524, 3 sheets.

Hindall, S.M., and Borman, R.G., 1974, Water resources of Wisconsin-lower Wisconsin River basin: U.S. Geological Survey Hydrologic Investigations Atlas HA-479, 3 sheets.

Young, H.L., and Borman, R.D., 1973, Water resources of Wisconsin-Trempealeau-Black River basin: U.S. Geological Survey Hydrologic Investigations Atlas HA-474, 4 sheets.

Oakes, E.L., and Hamilton, L.J., 1973, Water resources of Wisconsin-Menominee-Ocontc-Peshtigo River basin, U.S. Geological Survey Hydrologic Investigations Atlas HA-470, 4 sheets.

Hindall, S.M., and Skinner, E.L., 1973, Water resources of Wisconsin-Pecatonica-Sugar River basin: U.S. Geological Survey Hydrologic Investigations Atlas HA-453, 3 sheets.
Young, H.L., and Hindall, S.M., 1973, Water resources of Wisconsin-St. Croix River basin: U.S. Geological Survey Hydrologic Investigations Atlas HA-451, 4 sheets.

Skinner, E.L., and Borman, R.G., 1973, Water resources of Wisconsin-Lake Michigan basin: U.S. Geological Survey Hydrologic Investigations Atlas HA-432, 4 sheets.

Shearman, J.O., and Holmstrom, B.K., 1971, Floods on Rock River in southwestern Jefferson County, Wisconsin: U.S. Geological Survey Hydrologic Investigations Atlas HA-413, 1 sheet.

1971, Floods on Rock River in northeastern Jefferson County, Wisconsin: U.S. Geological Survey Hydrologic Investigations Atlas HA-394, 1 sheet.

Sherman, J.O., 1970, Floods on Rock River in northern Rock County, Wisconsin: U.S. Geological Survey Hydrologic Investigations Atlas HA-393, 1 sheet.

Gebert, W.A., 1971, Low-flow frequency of Wisconsin streams: U.S. Geological Survey Hydrologic Investigations Atlas HA- 390, 1 sheet.

Young, H.L., and Hindall, S.M., 1972, Water resources of Wisconsin-Chippewa River basin: U.S. Geological Survey Hydrologic Investigations Atlas HA-386, 4 sheets.

Hindall, S.M., and Flint, R.F., 1970, Sediment yields of Wisconsin streams: U.S. Geological Survey Hydrologic Investigations Atlas HA-376, 1 sheet.

Devaul, R.W., and Green, J.H., 1971, Water resources of Wisconsincentral Wisconsin River basin: U.S. Geological Survey Hydrologic Investigations Atlas HA-367, 4 sheets.

Cotter, R.D., Hutchinson, R.D., Skinner, E.L., and Wentz, D.A., 1969, Water resources of Wisconsin-Rock-Fox River basin: U.S. Geological Survey Hydrologic Investigations Atlas HA-360, 4 sheets.

Olcott, P.G., 1968, Water resources of Wisconsin-Fox-Wolf River basin: U.S. Geological Survey Hydrologic Investigations Atlas HA-321, 4 sheets.

U.S. Geological Survey, 1965, Preliminary map of the conterminous United States showing depth to and quality of shallowest ground water containing more than 1,000 parts per million dissolved solids: U.S. Geological Survey Hydrologic Investigations Atlas HA-199, 31 p., 2 sheets.

\section{PROFESSIONAL PAPERS}

Young, H.L., 1992, Summary of ground-water hydrology of the Cambrian-Ordovician aquifer system in the northern midwest, United States: U.S. Geological Survey Professional Paper 1405-A, 55 p.

1992, Hydrogeology of the Cambrian-Ordovician aquifer system in the northern midwest, United States: U.S. Geological Survey Professional Paper 1405-B, 99 p., 1 pl.

Mandle, R.J., and Kontis, A.L., 1992, Simulation of regional groundwater flow in the Cambrian-Ordovician aquifer system in the northern midwest, United States: U.S. Geological Survey Professional Paper 1405-C, $97 \mathrm{p}$.

Siegel, D.I., 1989, Geochemistry of the Cambrian-Ordovician aquifer system in the northern midwest, United States: U.S. Geological Survey Professional Paper 1405-D, 76 p.

Green, J.H., 1968, The Troy Valley of southeastern Wisconsin: U.S. Geological Survey Professional Paper 600-C, p. 135-139. 
Carey, K.L., 1967, The underside of river ice, St. Croix River, Wisconsin: U.S. Geological Survey Professional Paper 575-C, p. 195-199.

1966, Observed configuration and computed roughness of the underside of river ice, St. Croix River, Wisconsin: U.S. Geological Survey Professional Paper 550-B, p. 192-198.

Weeks, E.P., 1964, Field methods for determining vertical permeability and aquifer anisotropy: U.S. Geological Survey Professional Paper 501-D, p. 193-198.

1964, Use of water-level recession curves to determine the hydraulic properties of glacial outwash in Portage County, Wisconsin: U.S. Geological Survey Professional Paper 501-B, p. 181-184.

\section{WATER-RESOURCES INVESTIGATIONS REPORTS}

Grannemann, N.G., Hunt, R.J., Nicholas, J.R., Reilly, T.E., and Winter, T.C., 2000, The importance of ground water in the Great Lakes Region: U.S. Geological Survey Water-Resources Investigations Report 00-4008, 14 p.

Brown, Timothy A., Dunning, Charles P., and Sharpe, Jennifer B., 2000, Altitude, depth, and thickness of the Galena-Platteville bedrock unit in the subcrop area of Illinois and Wisconsin: U.S. Geological Survey Water-Resources Investigations Report 974054-C, 4 sheets.

Lenz, Bernard N. and Rheaume, S.J., Benthic invertebrates of fixed sites in the Western Lake Michigan Drainages, Wisconsin and Michigan, 1993-95: U.S. Geological Survey Water-Resources Investigations Report 95-4211-D, 30 p.

Krohelski, J.T., Feinstein, D.T., and Lenz, B.N., 1999, Simulation of stage and hydrologic budget for Shell Lake, Washburn County, Wisconsin: U.S. Geological Survey Water-Resources Investigations Report 99-4209, 23 p.

Batten, W.G., Yeskis, D.J., and Dunning, C.P., 1999, Hydrogeologic properties of the Ordovician Sinnipee Group at test well BN483, better brite superfund site, De Pere, Wisconsin: U.S. Geological Survey Water-Resources Investigations Report 99. 4199, 19 p.

Waschbusch, R.J., 1999, Evaluation of the effectiveness of an urban stormwater treatment unit in Madison, Wisconsin, 1996-97: U.S. Geological Survey Water-Resources Investigations Report 99. 4195, 49 p.

Steuer, Jeffrey S., Hall, David W., and Fitzgerald, Sharon A., 1999, Distribution and transport of polychlorinated biphenyls and associated particulates in the Hayton Millpond, South Branch Manitowoc River, 1993-95: U.S. Geological Survey Water-Resources Investigations Report 99-4101, 20 p.

Steuer, Jeffrey S., Fitzgerald, Sharon A., and Hall, David, 1999, Distribution and transport of polychlorinated biphenyls and associated particulates in the Milwaukee River system, Wisconsin, 1993-95: U.S. Geological Survey Water-Resources Investigations Report $99-4100,37 \mathrm{p}$

Fitzpatrick, Faith A., Knox, James C., and Whitman, Heather E., 1999 , Effects of historical land-cover changes on flooding and sedimentation, North Fish Creek, Wisconsin: U.S. Geological Survey Water-Resources Investigations Report 99-4083, 12 p.

Waschbusch, R.J., Selbig, W.R., and Bannerman, R.T., 1999, Sources of phosphorus from two urban residential basins in Madison, Wisconsin, 1994-95, U.S. Geological Survey Water-Resources Investigations Report 99-4021, $47 \mathrm{p}$.
Saad, David A., and Schmidt, Morgan A., 1999, Water-resources-related information for the Oneida Reservation and vicinity, Wisconsin, U.S. Geological Survey Water-Resources Investigations Report 98-4266, $57 \mathrm{p}$.

Saad, David A., and Thorstenson, Donald C., 1998, Flow and geochemistry along shallow ground-water flowpaths in an agricultural area in southeastern Wisconsin: U.S. Geological Survey Water-Resources Investigations Report 98-4179, 62 p.

Robertson, Dale M., 1998, Evaluation of the surface-water sampling design in the Western Lake Michigan Drainages in relation to environmental factors affecting water quality at base flow, U.S. Geological Survey Water-Resources Investigations Report 98-4072, $53 \mathrm{p}$.

Walker, John F., Saad, David A., and Krohelski, James T., 1998, Optimization of ground-water withdrawal in the lower Fox River communities, Wisconsin: U.S. Geological Survey WaterResources lnvestigations Report 97-4218, 24 p.

Richards, Kevin D., Sullivan, Daniel J., and Stewart, Jana S., 1998, Surface-water quality at fixed sites in the Western Lake Michigan Drainages, Wisconsin and Michigan, and the effects of natural and human factors, 1993-95, U.S. Geological Survey Water-Resources Investigations Report 97-4208, $40 \mathrm{p}$.

Stewart, Jana S., 1998, Combining satellite data with ancillary data to produce a refined land-use/land-cover map: U.S. Geological Survey Water-Resources lnvestigations Report 97-4203, 11 p., 3 pl.

Conlon, T.D., 1998, Hydrogeology and simulation of ground-water flow in the sandstone aquifer, northeastern Wisconsin: U.S. Geological Survey Water-Resources Investigations Report 97-4096, $60 \mathrm{p} ., 1 \mathrm{pl}$.

Elder, John F., Manion, Bart J., and Goddard, Gerald L., 1997, Mesocosm experiments to assess factors affecting phosphorus retention and release in an extended Wisconsin wetland: U.S. Geological Survey Water-Resources Investigations Report 97 $4272,14 \mathrm{p}$.

Steuer, Jeffrey, Selbig, William, Hornewer, Nancy, and Prey, Jeffrey, 1997, Sources of contamination in an urban basin in Marquette, Michigan and an analysis of concentrations, loads, and data quality: U.S. Geological Survey Water-Resources Investigations Report $97-4242,25 \mathrm{p}$.

Peters, Charles A., et al, 1997, Environmental setting and implications for water quality in the Western Lake Michigan drainage: U.S. Geological Survey Water-Resources Investigations Report 974196, $79 \mathrm{p}$.

Scudder, Barbara C., Sullivan, Daniel J., Fitzpatrick, Faith A., and Rheaume, Stephen J., 1997, Trace elements and synthetic organic compounds in biota and streambed sediment of the Western Lake Michigan drainages, 1992-1995: U.S. Geological Survey WaterResources Investigations Report 97-4192, 34 p.

Fitzgerald, Sharon A., 1997, Results of quality-control sampling of water, bed sediment, and tissue in the Western Lake Michigan drainages study unit of the national water-quality assessment program: U.S. Geological Survey Water-Resources Investigations Report 97-4148, 24 p.

Batten, W.G., Brown, T.A., Mills, P.C., and Sabin, T.J., 1997, Rockstratigraphic nomenclature, lithology, and subcrop area of the Galena-Platteville bedrock unit in Illinois and Wisconsin: U.S. Geological Survey Water Resources Investigations Report 97. 4054-B, 1 sheet.

Sullivan, Daniel J. and Peterson, Elise M., 1997, Fish communities of benchmark streams in agricultural areas of eastern Wisconsin: Water Resources Investigations Report 96-4038-D, 23 p. 
Sullivan, Daniel J., 1997, Fish communities of fixed sites in the Western Lake Michigan drainages, Wisconsin and Michigan, 1993-95: U.S. Geological Survey Water-Resources Investigations Report 95-4211-C, $23 \mathrm{p}$.

Fitzpatrick, Faith A., and Giddings, Elise M.P., 1997, Stream habitat characteristics of fixed sites in the Western Lake Michigan drainages, Wisconsin and Michigan, 1993-95: U.S. Geological Survey Water-Resources Investigations Report 95-4211-B, 58 p.

Garn, Herbert S., Olson, Daniel L., Seidel, Tracy L., and Rose, William J., 1996, Hydrology and water quality of Lauderdale Lakes, Walworth County, Wisconsin, 1993-94: U.S. Geological Survey Water-Resources Investigations Report 96-4235, 29 p.

Conlon, T.D., 1996, Hydrogeology of the sand and gravel aquifer in the vicinity of the Wild Rose State Fish Hatchery, North-Central Waushara County, Wisconsin: U.S. Geological Survey WaterResources Investigations Report 96-4213, 14 p.

Legg, Andrew D., Bannerman, Roger T., and Panuska, John, 1996, Variation in the relation of rainfall to runoff from residential lawns in Madison, Wisconsin, July and August 1995: U.S. Geological Survey Water-Resources Investigations Report 96-4194, $11 \mathrm{p}$.

Robertson, Dale M., Field, Stephen J., Elder, John F., Goddard, Gerald L., and James, William F., 1996, Phosphorus dynamics in Delavan Lake Inlet, Southeastern Wisconsin, 1994: U.S. Geological Survey Water-Resources Investigations Report 96-4160, $18 \mathrm{p}$

Robertson, Dale M., 1996, Use of frequency-volume analyses to estimate regionalized yields and load of sediment, phosphorus, and polychlorinated biphenyls to Lakes Michigan and Superior: U.S. Geological Survey Water-Resources Investigations Report 964092, 47 p.

Fitzpatrick, Faith A., Peterson, Elise M., and Stewart, Jana S., 1996, Habitat characteristics of benchmark streams in agricultural areas of Eastern Wisconsin: U.S. Geological Survey Water-Resources Investigations Report 96-4038-B, 35 p.

Rheaume, S.J., Stewart, J.S., and Lenz, Bernard N., 1996, Environmental setting of benchmark streams in agricultural areas of Eastern Wisconsin: U.S. Geological Survey Water-Resources Investigations Report 96-4038-A, 50 p.

Robertson, Dale M., and Saad, David A., 1996, Water-quality assessment of the Western Lake Michigan drainages-analysis of available information on nutrients and suspended sediment, water years 1971-90: U.S. Geological Survey Water Resources Investigations Report 96-4012,165 p.

Rose, William J,. and Graczyk, David J., 1996, Sediment transport, particle size, and loads in North Fish Creek in Bayfield County, Wisconsin, water years 1990-91: U.S. Geological Survey WaterResources Investigations Report 95-4222, 18 p.

Batten, W.G., and Lidwin, R.A., 1996, Water resources of the Lac du Flambeau Indian Reservation, Wisconsin, 1981-86: U.S. Geological Survey Water-Resources Investigations Report 94-4025, 42 p., 3 pls.

Sullivan, D.J., Peterson, E.M., and Richards, K.D., 1995, Environmental setting of fixed sites in the Western Lake Michigan Drainages, Michigan and Wisconsin: U.S. Geological Survey WaterResources Investigations Report 95-4211-A, $30 \mathrm{p}$.

Batten, W. G., and Lidwin, R.A., 1995, Water resources of the Bad River Indian Reservation, northern Wisconsin: U.S. Geological Survey Water-Resources Investigations Report 95-4207, 45 p., $2 \mathrm{pl}$.
Conlon, T. D., 1995, Hydrogeology of southwestern Sheboygan County, Wisconsin, in the vicinity of the Kettle Moraine Springs Fish Hatchery: U.S. Geological Survey Water-Resources Investigations Report 94-4106, 17 p.

Corsi, S. R., and Schuler, J.G., 1995, Discharge ratings for tainter gates and roller gates at Lock and Dam No. 7 on the Mississippi River, La Crescent, Minnesota: U.S. Geological Survey Water Resources Investigations Report 95-4089, 17 p.

DeWild, John F., and Krohelski, James T., 1995, Radon-222 concentrations in ground water and soil gas on Indian Reservations in Wisconsin: U.S. Geological Survey Water-Resources Investigations Report 95-4088, 12 p.

Kammerer, P.A., Jr., 1995, Ground-water flow and quality in Wisconsin's shallow aquifer system: U.S. Geological Survey Water-Resources Investigations Report 90-4171, 42 p., 2 pl.

Goddard, Gerald L., and Field, Stephen J., 1994, Hydrology and water quality of Whitewater and Rice Lakes in southeastern Wisconsin, 1990-91: U.S. Geological Survey Water-Resources Investigations Report 94-4101, 36 p.

Krohelski, James T., Kammerer, Jr., Phil A., and Conlon, Terrence D., 1994, Water resources of the Menominee Indian Reservation of Wisconsin: U.S. Geological Survey Water-Resources Investigations Report 93-4053, 54 p., 4 pl.

Rose, William J., 1993, Hydrology of Little Rock Lake in Vilas County, north-central Wisconsin: U.S. Geological Survey WaterResources Investigations Report 93-4139, 22 p.

Graczyk, D.J., 1993, Surface-water hydrology and quality, and macroinvertebrate and smallmouth bass populations in four stream basins in southwestern Wisconsin, 1987-90: U.S. Geological Survey Water-Resources Investigations Report 93-4024, 70 p.

Batten, W.G., and Conlon, T.D., 1993, Hydrogeology of glacial deposits in a preglacial bedrock valley, Waukesha County, Wisconsin: U.S. Geological Survey Water-Resources Investigations Report 92-4077, 15 p.

House, L.B., 1993, Simulation of the effects of hypothetical residential development on water levels in Graber Pond, Middleton, Wisconsin: U.S. Geological Survey Water-Resources Investigations Report 92-4029, 10 p.

Krohelski, J.T., and Lidwin, R.A., 1993, Hydrology and water quality of the Forest County Potawatomi Indian Reservation, Wisconsin U.S. Geological Survey Water-Resources Investigations Report 91-4136, 24 p.

Rose, William J., 1993, Water and phosphorus budgets and trophic state, Balsam Lake, northwestern Wisconsin, 1987-1989: U.S Geological Survey Water-Resources Investigations Report 91 4125,28 p.

Field, S.J., 1993, Hydrology and water quality of Powers Lake, southeastern Wisconsin: U.S. Geological Survey Water-Resources Investigations Report 90-4126, $36 \mathrm{p}$.

Field, Stephen J., 1993, Hydrology and water quality of Wind Lake in southeastern Wisconsin: U.S. Geological Survey WaterResources Investigations Report 91-4107,61 p.

Hughes, P.E., 1993, Hydrology, water quality, trophic status, and aquatic plants of Fowler Lake, Wisconsin: U.S. Geological Survey Water-Resources Investigations Report 91-4076, 44 p.

Krug, William R., Conger, Duane H., and Gebert, Warren A., 1992, Flood-frequency characteristics of Wisconsin streams: U.S Geological Survey Water-Resources Investigations Report 914128,185 p., 2 pls 
Rose, W.J., 1992, Sediment transport, particle sizes, and loads in lower reaches of the Chippewa, Black, and Wisconsin Rivers in western Wisconsin: U.S. Geological Survey Water-Resources Investigations Report 90-4124, 38 p.

Wentz, D.A., and Rose, W.J., 1991, Hydrology of Lakes Clara and Vandercook in North-Central Wisconsin: U.S. Geological Survey Water-Resources Investigations Report 89-4204, 24 p.

Patterson, G. L., 1990, Ground-water levels and quality at Crex Meadows Wildlife Area, Burnett County, Wisconsin: U.S. Geological Survey Water-Resources Investigations Report 89$4129,19 \mathrm{p}$.

Field, S.J., and Graczyk, D.J., 1990, Hydrology, aquatic macrophytes, and water quality of Black Earth Creek and its tributaries, Dane County, Wisconsin, 1985-86: U.S. Geological Survey WaterResources Investigations Report 89-4089, 44 p.

Krug, W.R., Gebert, W.A., Graczyk, D.J., Stevens, D.L., Jr., Rochelle, B.P., Church, M.R., and Campbell, W.G., 1988, Runoff map for the Northeastern, Southeastern, and Mid-Atlantic United States for water years 1951-80: U.S. Geological Survey WaterResources Investigations Report 88-4094, $44 \mathrm{p}$

Rose, William J., 1988, Water resources of the Apostle Islands National Lakeshore, Northern Wisconsin: U.S. Geological Survey Water-Resources Investigations Report 87-4220, $44 \mathrm{p}$.

Field, Stephen J., and Duerk, Marvin D., 1988, Hydrology and water quality of Delavan Lake in southeastern Wisconsin: U.S. Geological Survey Water-Resources Investigations Report 87$4168,61 \mathrm{p}$.

Walker, J.F., Osen, L.L., and Hughes, P.E., 1987, Cost effectiveness of the U.S. Geological Survey's stream-gaging program in Wisconsin: U.S. Geological Survey Water-Resources Investigations Report 86-4125, $44 \mathrm{p}$

Krohelski, J.T., Ellefson, B.R., and Storlie, C.A., 1987, Estimated use of ground water for irrigation in Wisconsin, 1984: U.S. Geological Survey Water-Resources Investigations Report 864079, 12 p., $1 \mathrm{pl}$.

House, L.B., 1987, Simulation of unsteady flow in the Milwaukee Harbor Estuary at Milwaukee, Wisconsin: U.S. Geological Survey Water-Resources Investigations Report 86-4050, 19 p.

Conger, D.H., 1986, Estimating magnitude and frequency of floods for Wisconsin urban streams: U.S. Geological Survey WaterResources Investigations Report 86-4005, 18 p.

Graczyk, D.J., 1986, Water quality in the St. Croix National Scenic Riverway, Wisconsin: U.S. Geological Survey Water-Resources Investigations Report 85-4319, $48 \mathrm{p}$.

Field, S.J., 1986, Relations between precipitation, streamflow, and water quality in the Galena River basin, Wisconsin: U.S. Geological Survey Water-Resources Investigations Report 85 $4214,48 \mathrm{p}$.

Emmons, P.J., 1987, An evaluation of the bedrock aquifer system in northeastern Wisconsin: U.S. Geological Survey WaterResources Investigations Report 85-4199, 48 p.

Krug, W.R., and Goddard, G.L., 1986, Effects of urbanization on streamflow, sediment loads, and channel morphology in Pheasant Branch basin near Middleton, Wisconsin: U.S. Geological Survey Water-Resources Investigations Report 85-4068, 82 p.

Cotter, R.D., 1986, Hydrogeology and ground-water quality of Lannon-Sussex Area, northeastern Waukesha County, Wisconsin: U.S. Geological Survey Water-Resources Investigations Report 84-4213, 28 p.
Field, S.J., 1985, Nonpoint-source discharges and water quality of Elk Creek basin, west-central Wisconsin: U.S. Geological Survey Water-Resources Investigations Report 84-4094, $38 \mathrm{p}$.

Field, S.J., and Lidwin, R.A., 1984, An assessment of nonpoint-source discharges, streamflow, and water quality in Onion River. Wisconsin: U.S. Geological Survey Water-Resource Investigations Report 84-4066, 78 p.

House, L.B., 1984, Effects of urbanization on three ponds in Middleton, Wisconsin: U.S. Geological Survey Water-Resources Investigations Report 84-4051, $17 \mathrm{p}$.

Kammerer, P.A., Jr., 1984, An overview of ground-water-quality data in Wisconsin: U.S. Geological Survey Water-Resources Investigations Report 83-4239, 58 p.

Krug, W.R., and House, L.B., 1984, Evaluation of alternative reservoir-management practices in the Rock River basin, Wisconsin: U.S. Geological Survey Water-Resources Investigations Report 83-4186, 21 p.

Duerk, M.D., 1983, Automatic dilution gaging of rapidly varying flow: U.S. Geological Survey Water-Resources Investigations Report $83-4088,17 \mathrm{p}$.

Kammerer, P.A., Jr., Lidwin, R.A., Mason, J.W., and Narf, R.P., 1983, Aquatic biology in Nederlo Creek, southwestern Wisconsin: U.S Geological Survey Water Resources Investigations 82-56, 27 p.

Lawrence, C.L., and Ellefson, B.R., 1982, Water use in Wisconsin, 1979: U.S. Geological Survey Water-Resources Investigations $82-444,98 \mathrm{p}$.

Wentz, Dennis A., and Graczyk, David J., 1982, Effects of a floodwater-retarding structure on the hydrology and ecology of Trout Creek in southwestern Wisconsin: U.S. Geological Survey Water-Resources Investigations $82-23,68 \mathrm{p}$.

Holmstrom, B.K., 1982, Low-flow characteristics of streams in the Lake Michigan basin, Wisconsin: U.S. Geological Survey WaterResources Investigations Open-File Report 81-1193, 102 p.

House, Leo B., 1981, An assessment of streamflow, water quality, and the effects of construction on impoundment on Bridge Creek at Augusta, Wisconsin: U.S. Geological Survey Water-Resources Investigations Open-File Report 81-1192, 25 p.

Field, S.J., and Lidwin, R.A., 1982, Water-quality assessment of Steiner Branch basin, Lafayette County, Wisconsin: U.S. Geological Survey Water-Resources Investigations 81-52, 58 p.

Gebert, W.A., 1982, Low-flow characteristics of streams in the Central Wisconsin River basin, Wisconsin: U.S. Geological Survey Water-Resources Investigations Open-File Report 81-495, 99 p.

Conger, Duane H., 1981, Techniques for estimating magnitude and frequency of floods for Wisconsin streams: U.S. Geological Survey Water-Resources Investigations Open-File Report 80$1214,116 \mathrm{p}$.

Krug, William R., and House, Leo B., 1980, Streamflow model of Wisconsin River for estimating flood frequency and volume: U.S. Geological Survey Water-Resources Investigations 80$1103,44 \mathrm{p}$

Holmstrom, B.K., 1980, Low-flow characteristics of streams in the Menominee-Oconto-Peshtigo River basin, Wisconsin: WaterResources Investigations Open-File Report 80-749, 82 p.

1980, Low-flow characteristics of streams in the St. Croix River basin, Wisconsin: U.S. Geological Survey Water-Resources Investigations Open-File Report 80-696, 62 p. 
Gebert, W.A., 1980, Low-flow characteristics of streams in the upper Wisconsin River basin, Wisconsin: U.S. Geological Survey Water-Resources Investigations Open-File Report 80-69l, 60 p.

Krug, William R., 1981, Hydrologic effects of proposed changes in management practices, Winnebago Pool, Wisconsin: U.S. Geological Survey Water-Resources Investigations 80-107, 19 p.

House, Leo B., and Skavroneck, Steven, 1981, Comparison of the propane-area tracer method and predictive equations for determination of stream-reaeration coefficients on two small streams in Wisconsin: U.S. Geological Survey Water-Resources Investigations $80-105,18 \mathrm{p}$.

Kontis, A.L., and Mandle, R.J., 1980, Data-base system for northern Midwest regional aquifer-system analysis: U.S. Geological Survey Water-Resources Investigations 80-104, 27 p.

Grant, R.S., and Goddard, Gerald, 1980, Channel erosion and sediment transport in Pheasant Branch basin near Middleton, Wisconsin, a preliminary report: U.S. Geological Survey Water-Resources Investigations Open-File Report 80-161, 19 p., 11 figs., 3 tables.

McLeod, R.S., 1980, The effects of using ground water to maintain water levels of Cedar Lake, Wisconsin: U.S. Geological Survey Water-Resources Investigations 80-23, $35 \mathrm{p}$.

Grant, R.S., and Skavroneck, Steven, 1980, Comparison of tracer methods and predictive models for determination of stream-reaeration coefficients on three small streams in Wisconsin: U.S. Geological Survey Water-Resources Investigations 80-19, $36 \mathrm{p}$.

Hindall, S.M., 1979, Ground-water quality in selected areas of Wisconsin: U.S. Geological Survey Water-Resources Investigations Open-File Report 79-1594, 20 p.

Stedfast, D.A., 1979, Low-flow characteristics of streams in the Pecatonica-Sugar River basin, Wisconsin: U.S. Geological Survey Water-Resources Investigations Open-File Report 79$1274,92 \mathrm{p}$.

Grant, R.S., and Goddard, Gerald, 1979, Urban storm-runoff modeling-Madison, Wisconsin: U.S. Geological Survey WaterResources Investigations Open-File Report 79-1273, 20 p.

Novitzki, R.P., and Holmstrom, B.K., 1979, Monthly and annual water budgets of Lake Wingra, Madison, Wisconsin, 1971-77: U.S. Geological Survey Water-Resources Investigations 79-100, 31 p.

Kammerer, P.A., and Sherrill, M.G., 1979, Hydrology and water quality in the Nederlo Creek basin before construction of two waterretention structures: U.S. Geological Survey Water-Resources Investigations $79-95,42 \mathrm{p}$

Gebert, W.A., 1979, Low-flow characteristics of streams in Lake Superior basin, Wisconsin: U.S. Geological Survey WaterResources Investigations 79-38, $74 \mathrm{p}$.

Holmstrom, B.K., 1979, Low-flow characteristics of Wisconsin streams at sewage-treatment plants and industrial plants: U.S. Geological Survey Water-Resources Investigations 79-31, $123 \mathrm{p}$.

Gebert, W.A., 1979, Red Cedar River basin, Wisconsin: Low-flow characteristics: U.S. Geological Survey Water-Resources Investigations 79-29, $12 \mathrm{p}$.

Holmstrom, B.K., 1979, Low-flow characteristics of streams in the Trempealeau-Black River basin, Wisconsin: U.S. Geological Survey Water-Resources Investigations 79-9, $79 \mathrm{p}$

Sherrill, M.G., 1979, Contamination potential in the Silurian dolomite aquifer, eastern Wisconsin: U.S. Geological Survey WaterResources Investigations 78-108, 2 pls.
Holmstrom, B.K., 1978, Low-flow characteristics of streams in the Rock-Fox River basin, Wisconsin: U.S. Geological Survey Water-Resources Investigations 78-85, $98 \mathrm{p}$

Rathbun, R.E., and Grant, R.S., 1978, Comparison of the radioactive and modified techniques for measurement of stream reaeration coefficients: U.S. Geological Survey Water-Resources Investigations $78-68,65 \mathrm{p}$.

Field, S.J., 1978, Ten-year low mean monthly discharge determinations for ungaged streams near waste-stabilization ponds in Wisconsin: U.S. Geological Survey Water-Resources Investigations $78-49,16 \mathrm{p}$.

Novitzki, R.P., 1978, Hydrology of the Nevin wetland near Madison, Wisconsin: U.S. Geological Survey Water-Resources Investigations $78-48,25 \mathrm{p}$.

Grant, R.S., 1978, Reaeration capacity of the Rock River between Lake Koshkonong, Wisconsin, and Rockton, Illinois: U.S. Geological Survey Water-Resources Investigations 77-128, $33 \mathrm{p}$.

Gebert, W.A., 1978, Low-flow characteristics of streams in the lower Wisconsin River basin: U.S. Geological Survey Water-Resources Investigations $77-118,80 \mathrm{p}$.

Gebert, W.A., and Holmstrom, B.K., 1977, Low-flow characteristics at gaging stations on the Wisconsin, Fox, and Wolf Rivers, Wisconsin: U.S. Geological Survey Water-Resources Investigations $77-27,20 \mathrm{p}$.

Rose, W.J., 1977, Hydrologic considerations associated with dredging spring ponds in Wisconsin: U.S. Geological Survey WaterResources Investigations $77-18,35 \mathrm{p}$

Krug, W.R., 1976, Simulation of streamflow of Flambeau River at Park Falls, Wisconsin, to define low-flow characteristics: U.S. Geological Survey Water-Resources Investigations 76-116, 14 p.

Grant, R.S., 1976, Reaeration of coefficient measurements of 10 small streams in Wisconsin using radioactive tracers- with a section on the energy-dissipation model: U.S. Geological Survey WaterResources Investigations 76-96, $50 \mathrm{p}$.

Novitzki, R.P., 1976, Recycling ground water in Waushara County, Wisconsin: Resource management for cold-water fish hatcheries: U.S. Geological Survey Water-Resources Investigations 76-20, $60 \mathrm{p}$.

Hindall, S.M., 1976, Measurement and prediction of sediment yields in Wisconsin streams: U.S. Geological Survey Water-Resources Investigations $54-75,27 \mathrm{p}$.

Oakes, E.L., Hendrickson, G.E., and Zuehls, E.E., 1975, Hydrology of the Lake Wingra basin, Dane County, Wisconsin: U.S. Geological Survey Water-Resources Investigations 17-75, 31 p.

Gebert, W.A., and Holmstrom, B.K., 1974, Low-flow characteristics of Wisconsin streams at sewage-treatment plants: U.S. Geological Survey Water-Resources Investigations 45-74, $101 \mathrm{p}$.

Hendrickson, G.E., Knutilla, R.L., and Doonan, C.J., 1973, Hydrology and recreation of selected cold-water rivers of the St. Lawrence River basin in Michigan, New York, and Wisconsin: U.S. Geological Survey Water-Resources Investigations 8-73, 73 p.

\section{OPEN-FILE REPORTS}

Corsi, S.R., Greb, S.R., Bannerman, R.T., and Pitt, R.E., 1999, Evaluation of the multi-chambered treatment train, a retrofit water-quality management device: U.S. Geological Survey Open-File Report 99-270, 24 p. 
Maertz, D.E., 1999, Water-resources investigations in Wisconsin, 1999: U.S. Geological Survey Open-File Report 99-229, 112 p.

Wisconsin District Lake-Studies Team, 1999, Water-quality and lakestage data for Wisconsin lakes, water year 1998: U.S. Geological Survey Open-File Report 99-98, 143 p

Krug, W. R., 1999, Simulation of the effects of operating Lakes Mendota, Monona, and Waubesa, south-central Wisconsin, as multipurpose reservoirs to maintain dry-weather flow: U.S. Geological Survey Open-File Report 99-67, 18 p.

Hall, D.W., Behrendt, T.E., and Hughes, P.E., 1998, temperature, pH, conductance, and dissolved oxygen in cross sections of 11 Lake Michigan tributaries, 1994-95: U.S. Geological Survey OpenFile Report 98-567, 85 p.

Maertz, D.E., 1998, Water-resources investigations in Wisconsin: U.S. Geological Survey Open-File Report 98-295, 96 p.

Wisconsin District Lake-Studies Team, 1998, Water-quality and lakestage data for Wisconsin lakes, water year 1997: U.S. Geological Survey Open-File Report 98-78, 129 p.

Ellefson, B.R., Fan, C.H., and Ripley, J.L., 1997, Water use in Wisconsin, 1995: U.S. Geological Survey Open-File Report 97-356, 1 sheet.

Maertz, D.E., 1997, Water-resources investigations in Wisconsin, U.S. Geological Survey Open-File Report 97-351, 91 p.

Wisconsin District Lake-Studies Team, 1997, Water-quality and lakestage data for Wisconsin lakes, water year 1996: U.S. Geological Survey Open-File Report 97-123, 134 p.

Rappold, K.F., Wierl, J.A., and Amerson, F.U., 1997, Watershed characteristics and land management in the nonpoint-source evaluation monitoring watersheds in Wisconsin: U.S. Geological Survey Open-File Report 97-119, 39 p.

Owens, D.W., Corsi, S.R., and Rappold, K.F., 1997, Evaluation of nonpoint-source contamination, Wisconsin: Selected topics for water year 1995: U.S. Geological Survey Open-File Report 96-661A, $41 \mathrm{p}$.

Bannerman, Roger T., Legg, Andrew D., and Greb, Steven R., 1996, Quality of Wisconsin stormwater 1989-94: U.S. Geological Survey Open-File Report 96-458, 26 p.

Maertz, D.E., 1996, Water-resources investigations in Wisconsin, U.S. Geological Survey Open-File Report 96-333, 74 p.

Wisconsin District Lake-Studies Team, 1996, Water-quality and lakestage data for Wisconsin lakes, water year 1995: U.S. Geological Survey Open-File Report 96-168, 123 p.

Wierl, J.A., Rappold, K.F., and Amerson, F.U., 1996, Summary of the land-use inventory for the nonpoint-source evaluation monitoring watersheds in Wisconsin: U.S. Geological Survey Open-File Report $96-123,23 \mathrm{p}$.

Steuer, J.J., Selbig, W.R. and Hornewer, N.J., 1996, Contaminant concentrations in stormwater from eight Lake Superior basin cities, 1993-94: U.S. Geological Survey Open-File Report 96-122, $16 \mathrm{p}$.

Waschbusch, R.J., 1996, Stormwater-runoff data, Madison, Wisconsin 1993-94: U.S. Geological Survey Open-File Report 95-733, $33 \mathrm{p}$.

Maertz, D.E., 1995, Water-resources investigations in Wisconsin, 1995: U.S. Geological Survey Open-File Report 95-328, 84 p.
Walker, J.R., Graczyk, D.J., Corsi, S.R., Owens, D.W., and Wierl, J.A., 1995, Evaluation of nonpoint-source contamination, Wisconsin: Land-use and best-management-practices inventory, selected streamwater-quality data, urban-watershed quality assurance and quality control, constituent loads in rural streams, and snowmeltrunoff analysis, water year 1994: U.S. Geological Survey OpenFile Report 95-320, $21 \mathrm{p}$

Wisconsin District Lake-Studies Team, 1995, Water-quality and lakestage data for Wisconsin lakes, water year 1994: U.S. Geological Survey Open-File Report 95-190, 157 p.

Peters, C.A., 1995, National Water-Quality Assessment Program, Western Lake Michigan Drainages-Summaries of Liaison Committee Meeting, Green Bay, Wisconsin, March 28-29, 1995: U.S Geological Survey Open-File Report 95-163, 57 p.

Corsi, S.R., Walker, J.F., Graczyk, D.J., Greb, S.R., Owens, D.W., and Rappold, K.F., 1995, Evaluation of nonpoint-source contamination, Wisconsin: Selected streamwater-quality data, land-use and best-management practices inventory, and quality assurance and quality control, water year 1993: U.S. Geological Survey OpenFile Report 94-707, 57 p

Krohelski, J.T., and Batten, W.G., 1995, Simulation of stage and the hydrologic budget of Devils Lake, Sauk County, Wisconsin: U.S. Geological Survey Open-File Report 94-348, 22 p.

House, Leo B., 1995, Distribution and transport of polychlorinated biphenyls in Little Lake Butte des Morts, Fox River, Wisconsin, April 1987-October 1988: U.S. Geological Survey Open-File Report 93-31, 43 p., 1 pl.

Maertz, D.E., 1994, Water-resources investigations in Wisconsin, 1994: U.S. Geological Survey Open-File Report 94-321.

Graczyk, D.J., Walker, J.F., Greb, S.R., Corsi, S.R., and Owens, D.W., 1993, Evaluation of nonpoint-source contamination, Wisconsin: Selected data for 1992 water year: U.S. Geological Survey OpenFile Report 93-630, 48 p.

House, Leo B., Waschbusch, Robert J., and Hughes, Peter E., 1993, Water quality of an urban wet detention pond in Madison, Wisconsin, 1987-88: U.S. Geological Survey Open-File Report 93-172, $57 \mathrm{p}$

House, L.B., Hughes, P.E., and Waschbusch, R.J., 1993, Concentrations and loads of polychlorinated biphenyls in major tributaries entering Green Bay, Lake Michigan, 1989-90: U.S. Geological Survey Open-File Report 93-132, 41 p.

Walker, John F., 1993, Techniques for detecting effects of urban and rural land-use practices on stream-water chemistry in selected watersheds in Texas, Minnesota, and 1llinois: U.S. Geological Survey Open-File Report 93-130, 16 p.

Maertz, D.E., 1993, Water-resources investigations in Wisconsin, 1993: U.S. Geological Survey Open-File Report 93-129, 91 p.

Ellefson, B.R., Sabin, T.J., and Krohelski, J.T., 1993, Water use in Wisconsin, 1990: U.S. Geological Survey Open-File Report 93118,1 sheet.

Maertz, D.E., 1992, Water-resources investigations in Wisconsin: Programs and activities of the U.S. Geological Survey, 19911992: U.S. Geological Survey Open-File Report 92-125, 93 p.

Elder, J.F., Krabbenhoft, D.P, and Walker, J.F., 1992, Water, energy, and biogeochemical budgets (WEBB) program: Data availability and research at the northern temperate lakes site, Wisconsin: U.S. Geological Survey Open-File Report 92-48, 15 p. 
Krabbenhoft, D.P., and Kroheiski, J.T., 1992, Data on water quality, lake sediment, and lake-level fluctuation, St. Croix Indian Reservation, Wisconsin, 1981-87: U.S. Geological Survey Open-File Report 92-26, 53 p.

Hughes, P.E., 1993, Hydrologic and water-quality data for the East River Basin of northeastern Wisconsin: U.S. Geological Survey Open-File Report 89-245, 91 p.

Setmire, J.G., 1991, National Water-Quality Assessment Program Western Lake Michigan Drainage Basin: U.S. Geological Survey Open-File Report 91-161, Water Fact Sheet, 2 p.

Melcher, N.B. and Walker, J.F., 1990, Evaluation of selected methods for determining streamflow during periods of ice effect: U.S. Geological Survey Open-File Report 90-554, 51 p.

U.S. Geological Survey, 1990, The effects of the 1988 drought on the water resources of Wisconsin: U.S. Geological Survey Open-File Report 90-149, Water Fact Sheet, 2 p.

House, L.B., 1990, Data on polychlorinated biphenyls, dieldrin, lead, and cadmium in Wisconsin and upper Michigan tributaries to Green Bay, July 1987 through April 1988: U.S. Geological Survey Open-File Report 89-52, 11 p

Gebert, Warren A., Graczyk, David J., and Krug, William R., 1988, Runoff for selected sites in Shenandoah National Park, Virginia, July 18, 1981 through July 17, 1982: U.S. Geological Survey Open-File Report 88-98, 13 p.

Ellefson, B.R., Rury, Kraig S., and Krohelski, James T., 1988, Water use in Wisconsin, 1985: U.S. Geological Survey Open-File Report 87-699.

Krug, W.R., Gebert, W.A., and Graczyk, D.J., 1989, Preparation of average annual runoff map of the United States, 1951-80: U.S. Geological Survey Open-File Report 87-535, 414 p.

Krug, William R., Ostenso, Nile A., and Krohelski, James T., 1988, Prediction of the effects of mine dewatering on four lakes near Crandon, Wisconsin, by use of a water-budget model: U.S. Geological Survey Open-File Report 87-471, 63 p.

Graczyk, David J., Gebert, Warren A., Krug, William R., and Allord, G.J., 1987, Maps of runoff in the Northeastern Region and southern Blue Ridge Province of the United States during selected time periods in 1983-85: U.S. Geological Survey Open-File Report 87-106, 8 p., 3 pl.

Graczyk, David J., Krug, William R., and Gebert, Warren A., 1986, A history of annual streamflows from the 21 water-resource regions in the United States and Puerto Rico, 1951-83: U.S. Geological Survey Open-File Report 86-128, 30 p.

Henrich, E.W., 1984, Drainage area data for Wisconsin Streams: U.S. Geological Survey Open-File Report 83-933, 322 p.

Lawrence, C.L., Ellefson, B.R., and Cotter, R.D., 1984, Public-supply pumpage in Wisconsin in 1979: U.S. Geological Survey OpenFile Report 83-931, $40 \mathrm{p}$

Lawrence, C.L., and Ellefson, B.R., Water use in Wisconsin, 1979 , U.S. Geological Survey Open-File Report 82-444, 98 p.

Novitzki, R.P., 1979, Streamflow estimates in selected Wisconsin streams: U.S. Geological Survey Open-File Report 79-1282, $11 \mathrm{p}$.

Harr, C.A., and Novitzki, R.P., 1979, Availability of supplemental water supplies at salmonid fish-propagation stations in Wisconsin: U.S. Geological Survey Open-File Report 79-1170, 13 p.
Krug, W.R., 1979, Simulation of streamflow of Rock River at Lake Koshkonong, Wisconsin, to determine effects of withdrawal of powerplant-cooling water: U.S. Geological Survey Open-File Report 79-253, $21 \mathrm{p}$

McLeod, R.S., 1978, Water-level declines in the Madison area, Dane County, Wisconsin: U.S. Geological Survey Open-File Report 78-936, $15 \mathrm{p}$.

Field, S.J., 1978, Low-flow characteristics of small streams in proposed Public Law 566 basins: U.S. Geological Survey Open-File Report 78-664, 32 p.

Hindall, S.M., 1978, Suspended-sediment transport in the Big Eau Pleine River basin, central Wisconsin: U.S. Geological Survey Open-File Report 78-313, 12 p.

Lawrence, C.L., 1976, Regional flood limits of lower Yahara River, Lake Waubesa and south, in Dane County, Wisconsin: U.S. Geological Survey Open-File Report 76-805, 20 p.

Krug, W.R., 1976, Probable maximum flood at Lake Chippewa near Winter, Wisconsin: U.S. Geological Survey Open-File Report $76-800,14 p$

Grant, R.S., 1976, Waste-assimilation study of Koshkonong Creek below sewage-treatment plant at Sun Prairie, Wisconsin: U.S. Geological Survey Open-File Report 76-655, 44 p.

Lawrence, C.L., 1976, Regional flood limits of upper Yahara River in Dane County, Wisconsin: U.S. Geological Survey Open-File Report 76-448, 15 p.

Holmstrom, B.K., 1976, Low-flow characteristics and mean annual discharge of North Branch Manitowoc River at Potter, Wisconsin: U.S. Geological Survey Open-File Report 76-204, $20 \mathrm{p}$.

Krug, W.R., 1976, Flood-plain delineation for regional flood in Dane County, Wisconsin: U.S. Geological Survey Open-File Report 76-164, $168 \mathrm{p}$.

Field, S.J., 1975, Low-flow study of the Pike River basin, Racine and Kenosha Counties, Wisconsin: U.S. Geological Survey OpenFile Report 75-653, 10 p.

Green, J.H., 1975, Flow characteristics of the lower Wisconsin River: U.S. Geological Survey Open-File Report 75-582, 9 p.

Holmstrom, B.K., 1975, Streamflow characteristics of Klawitter Creek basin near Westfield, Wisconsin: U.S. Geological Survey OpenFile Report 75-527, 14 p.

Krug, W.R., 1975, Analysis of operational plan for Lake Chippewa near Winter, Wisconsin: U.S. Geological Survey Open-File Report 75-487, $17 \mathrm{p}$

Holmstrom, B.K., 1975, Low-flow characteristics of the Eau Claire River basin near Antigo, Wisconsin: U.S. Geological Survey Open-File Report 75-336, 19 p.

Gebert, W.A., 1974, Streamflow characteristics of Little Wolf RiverHolt Creek basin near Galloway, Wisconsin: U.S. Geological Survey Open-File Report, 10 p.

Lawrence, C.L., and Holmstrom, B.K., 1973, Floods on Yahara River tributaries, Dane County, Wisconsin: U.S. Geological Survey Open-File Report, 19 p.

Grant, R.S., Krug, W.R., and Duerk, M.D., 1973, Floodplain and floodway delineation for regional flood in central Marathon County, Wisconsin: U.S. Geological Survey Open-File Report, 33 p. 
Holmstrom, B.K., Gebert, W.A., and Borman, R.G., 1973, Alder Creek hydrology, Wisconsin: U.S. Geological Survey Open-File Report, $28 \mathrm{p}$.

Lawrence, C.L., and Holmstrom, B.K., 1972, Flood in Starkweather Creek basin, Madison, Wisconsin: U.S. Geological Survey OpenFile Report, 15 p.

Holmstrom, B.K., 1972, Drainage-area data for Wisconsin streams: U.S. Geological Survey Open-File Report, 74 p. (Updated 1973, 1974, 1978, and 1979.)

Hindall, S.M., 1972, Sediment yields of Wisconsin streams: U.S. Geological Survey Open-File Report, 2 p.

Weeks, E.P., and Stangland, H.G., 1971, Effects of irrigation on streamflow in the central sand plains of Wisconsin: U.S. Geological Survey Open-File Report, 113 p.

Conger, D.H., 1971, Estimating magnitude and frequency of floods in Wisconsin: U.S. Geological Survey Open-File Report, 200 p.

Holmstrom, B.K., and Lawrence, C.L., 1971, Floods on Yahara River, Lake Mendota to Lake Kegonsa, Dane County, Wisconsin: U.S. Geological Survey Open-File Report, 12 p.

Lawrence, C.L., and Holmstrom, B.K., 1971, Floods on Yahara River, Lake Kegonsa dam to countyline, Dane County, Wisconsin: U.S. Geological Survey Open-File Report, 10 p.

Shearman, J.O., and Lawrence, C.L., 1971, Floods on Yahara River upstream from Lake Mendota, Dane County, Wisconsin: U.S. Geological Survey Open-File Report, 7 p.

Gebert, W.A., 1971, Hydrology of Pine Creek: U.S. Geological Survey Open-File Report, $6 \mathrm{p}$.

1971, Hulbert Creek hydrology, southwestern Wisconsin: U.S. Geological Survey Open-File Report, 11 p.

Gonthier, J.B., 1970, Water resources of southeastern WisconsinMilwaukee River basin: U.S. Geological Survey Open-File Report, 138 p. (Extensively used in preparation of "A comprehensive plan for the Milwaukee River watershed", v. 1 and 2, 1970 and 1971, Southeastern Wisconsin Regional Planning Commission Report No. 13, v. 1, 514 p. and v. 2,623 p.)

Hamilton, L.J., 1970, Availability of ground water in the lower Wisconsin River Valley, Wisconsin: U.S. Geological Survey Open-File Report, 45 p.

Campbell, R.E., and Dreher, F.C., 1970, A proposed stream-flow data program for Wisconsin: U.S. Geological Survey Open-File Report, $55 \mathrm{p}$.

Shearman, J.O., 1969, Evaluation of flood potential, part 2 of Floodplain management-Lake Koshkonong: U.S. Geological Survey Open-File Report, 6 p.

Young, K.B., 1965, Effect of treated effluent diversion on Yahara River flow: U.S. Geological Survey Open-File Report, 81 p.

1965, Supplement to report on flow characteristics of Wisconsin streams: U.S. Geological Survey Open-File Report, 81 p.

U.S. Geological Survey, 1964, Water-quality records in Michigan and Wisconsin: U.S. Geological Survey Open-File Report, 61 p.

Young, K.B., 1963, Flow characteristics of Wisconsin streams: U.S. Geological Survey Open-File Report, $151 \mathrm{p}$.

Erickson, D.W., 1961, Floods in Wisconsin, magnitude and frequency: U.S. Geological Survey Open-File Report, 109 p.
1961, Wisconsin River near Dekorra, Wisconsin, flood-flow characteristics at proposed bridge site on the Wisconsin Freeway in Columbia County: U.S. Geological Survey Open-File Report, $13 \mathrm{p}$.

Spicer, H.C., and Edwards, G.J., 1955, Electrical resistivity measurements in the Neillsville area, Wisconsin: U.S. Geological Survey Open-File Report, 34 p.

1954, A resistivity survey to locate an aquifer in the glacial deposits near Marshfield, Wisconsin: U.S. Geological Survey Open-File Report, 76 p.

Drescher, W.J., 1948, Results of pumping tests on artesian wells in the Milwaukee-Waukesha area, Wisconsin: U.S. Geological Survey Open-File Report, 22 p.

\section{OPEN-FILE MAPS}

Gonthier, J.B., 1979, Water-table map of Waukesha County, Wisconsin: U.S. Geological Survey Water-Resources Investigations Open-File Map 79-43, 1 pl.

Sherrill, M.G., and Erickson, J.R., 1979, Water-table map of Walworth County, Wisconsin: U.S. Geological Survey Water-Resources Investigations Open-File Map 79-42, $1 \mathrm{pl}$.

Sherrill, M.G., and Schiller, J.J., 1979, Water-table map of Racine County, Wisconsin: U.S. Geological Survey Water-Resources Investigations Open-File Map 79-41, 1 pl.

Sherrill, M.G., Schiller, J.J., and Erickson, J.R., 1979, Water-table map of Milwaukee County, Wisconsin: U.S. Geological Survey Water-Resources Investigations Open-File Map 79-40, 1 pl.

Sherrill, M.G., and Schiller, J.J., 1979, Water-table map of Kenosha County, Wisconsin: U.S. Geological Survey Water-Resources Investigations Open-File Map 79-39, 1 pl.

Borman, R.G., 1976, Thickness of unconsolidated materials of Walworth County, Wisconsin: U.S. Geological Survey OpenFile Report 76-465, scale 1:62,500.

1976, Water-table map of Walworth County, Wisconsin: U.S. Geological Survey Open-File Report 76-464, scale 1:62,500.

1976, Bedrock topography of Walworth County, Wisconsin: U.S. Geological Survey Open-File Report 76-463, scale 1:62,500.

1976, Bedrock geology of Walworth County, Wisconsin: U.S. Geological Survey Open-File Report 75-462, scale 1:62,500.

Gonthier, J.B., 1975, Bedrock topography of Waukesha County, Wisconsin: U.S. Geological Survey Open-File Report 75-572, scale $1: 62,500$.

1975, Water-table map of Waukesha County, Wisconsin: U.S Geological Survey Open-File Report 75-571, scale 1:62,500.

1975, Bedrock geology of Waukesha County, Wisconsin: U.S. Geological Survey Open-File Report 75-570, scale 1:62,500.

Borman, R.G., 1971, Preliminary map showing thickness of glacial deposits in Wisconsin: U.S. Geological Survey Open-File Report, scale $1: 2,500,000$

1971, Preliminary map of probable well yields from bedrock in Wisconsin: U.S. Geological Survey Open-File Report, scale $1: 2,500,000$. 
1971, Preliminary map of probable well yields from glacial deposits in Wisconsin: U.S. Geological Survey Open-File Report, scale 1:2,500,000.

\section{ADMINISTRATIVE REPORTS}

Rose, W.J., 1979, Bedload in northwestern Wisconsin's Nemadji River: U.S. Geological Survey Administrative Report, 12 p.

Hindall, S.M., and Graczyk, D.J., 1978, St. Croix National Scenic Riverway flood-plain delineation and water quality monitoring: U.S. Geological Survey Administrative Report, 47 p.

Kammerer, P.A., and Lidwin, R.A., 1977, Water quality in the Pine River basin Richland and Vernon Counties, Wisconsin: U.S. Geological Survey Administrative Report, 93 p.

Novitzki, R.P., 1971, Hydrologic investigations of Heart Lake, Green Lake County, Wisconsin: U.S. Geological Survey Administrative Report, 9 p.

1971, Hydrologic investigations for the Woodruff Fish Hatchery, Oneida County, Wisconsin: U.S. Geological Survey Administrative Report, 4 p.

1971, Hydrologic investigations of a proposed reservoir site in Trempealeau County, Wisconsin: U.S. Geological Survey Administrative Report, 4 p.

\section{FACT SHEETS}

Hunt, Randall J., Graczyk, David J., and Rose, William J., 2000, Water flows in the Necedah National Wildlife Refuge: U.S. Geological Survey Fact Sheet 068-00, 4 p.

Graczyk, David J., Robertson, Dale M., Rose, William J., and Steuer, Jeffrey J., 2000, Comparison of water-quality samples collected by siphon samplers and automatic samplers in Wisconsin: U.S. Geological Survey Fact Sheet 067-00, 4 p.

Graczyk, D.J., Vanden Brook, J.P., and Rheineck, B.D., 1999, Herbicides in the Pecatonica, Trempealeau, and Yahara Rivers in Wisconsin, May 1997-July 1998: U.S. Geological Survey Fact Sheet $167-99,9 \mathrm{p}$.

Wierl, Judy A., Giddings, Elise, M.P., and Bannerman, Roger T., 1998, Evaluation of a method for comparing phosphorus loads from barnyards and croplands in Otter Creek watershed, Wisconsin: U.S. Geological Survey Fact Sheet 168-98, 4 p.

Rose, W.J., and Robertson, D.M., 1998, Hydrology, water quality, and phosphorus loading of Kirby Lake, Barron County, Wisconsin: U.S. Geological Survey Fact Sheet 066-98, 4 p.

Stuntebeck, Todd D., and Bannerman, Roger T., 1998, Effectiveness of barnyard best management practices in Wisconsin: U.S. Geological Survey Fact Sheet 051-98, 4 p.

Team for evaluating the Wisconsin Water-Monitoring Network, 1998, Plan for an integrated long-term water-monitoring network for Wisconsin: U.S. Geological Survey Fact Sheet 048-98, 4 p.

Corsi, Steven R., Graczyk, David J., Owens, David W., and Bannerman, Roger T., 1997, Unit-area loads of suspended sediment, suspended solids, and total phosphorus from small watersheds in Wisconsin: U.S. Geological Survey Fact Sheet 195-97, 4 p.

Graczyk, David J., and Vanden Brook, James P., 1997, Herbicides in the Pecatonica and Yahara Rivers in southwestern Wisconsin, May 1996-July 1996: U.S. Geological Survey Fact Sheet 175-97, $4 \mathrm{p}$.
Lenz, Bernard N., 1997, Feasibility of combining two aquatic benthic macroinvertebrate community databases for water-quality assessment: U.S. Geological Survey Fact Sheet 132-97, 4 p.

Hunt, Randall J., 1996, Do created wetlands replace the wetlands that are destroyed: U.S. Geological Survey Fact Sheet 246-96, 4 p.

Elder, John F., and Goddard, Gerald L., 1996, Sediment and nutrient trapping efficiency of a constructed wetland near Delavan Lake, Wisconsin, 1993-1995: U.S. Geological Survey Fact Sheet 232 $96,4 \mathrm{p}$.

Kammerer, P.A., Jr., 1996, Hydrology and water quality of Park Lake, South-Central Wisconsin: U.S. Geological Survey Fact Sheet $197-96,4 \mathrm{p}$.

Matzen, Amy M., and Saad, David A., 1996, Pesticides in ground water in the Western Lake Michigan drainages, Wisconsin and Michigan, 1983-1995: U.S. Geological Survey Fact Sheet 192-96, 4 p.

U.S. Geological Survey, 1996, Real-time streamflow conditions: U.S. Geological Survey Fact Sheet 190-96, 2 p.

Krabbenhoft, David P., 1996, Mercury studies in the Florida Everglades: U.S. Geological Survey Fact Sheet 166-96, 4 p.

Fitzgerald, Sharon A., and Steuer, Jeffrey J., 1996, The Fox River PCB transport study - stepping stone to a healthy Great Lakes ecosystem: U.S. Geological Survey Fact Sheet 116-96, 4 p.

Sullivan, Daniel J., and Richards, Kevin D., 1996, Pesticides in streams in the Western Lake Michigan drainages, Wisconsin and Michigan, 1993-95: U.S. Geological Survey Fact Sheet 107-96, 4 p.

Stuntebeck, Todd D., 1995, Evaluating barnyard best management practices in Wisconsin using upstream-downstream monitoring: U.S. Geological Survey Fact Sheet 221-95, 4 p.

Robertson, Dale M., and Saad, David A., 1995, Environmental factors used to subdivide the Western Lake Michigan Drainages into relatively homogeneous units for water-quality site selection: U.S. Geological Survey Fact Sheet 220-95, 4 p.

Krabbenhoft, D.P., and Rickert, D.A., 1995, Mercury contamination of aquatic ecosystems: U.S. Geological Survey Fact Sheet 216-95, $4 \mathrm{p}$.

Saad, David A., 1995, Nitrate in ground water in the Western Lake Michigan Drainage Basin, Wisconsin and Michigan: U.S. Geological Survey Fact Sheet 070-94, 2 p.

\section{WISCONSIN GEOLOGICAL AND NATURAL HISTORY SURVEY INFORMATION CIRCULARS}

Batten, W.G., 1989, Hydrogeology of Wood County, Wisconsin: Wisconsin Geological and Natural History Survey Information Circular 60, 27 p., 2 pls.

Patterson, G.L., and Zaporozec, Alexander, 1988, Analysis of waterlevel fluctuations in Wisconsin wells: Wisconsin Geological and Natural History Survey Information Circular 63, 38 p.

Batten, W.G., 1987, Water resources of Langlade County, Wisconsin: Wisconsin Geological and Natural History Survey Information Circular 58, 28 p., 1 pl.

Krohelski, J.T., 1986, Hydrogeology and ground-water use and quality, Brown County, Wisconsin: Wisconsin Geological and Natural History Survey Information Circular 57, 42 p. 
House, L.B., 1986, Stage fluctuations of Wisconsin Lakes: Wisconsin Geological and Natural History Survey Information Circular No. 49,84 p.

Devaul, R.W., Harr, C.A., and Schiller, J.J., 1983, Ground-water resources and geology of Dodge County, Wisconsin: Wisconsin Geological and Natural History Survey Information Circular 44, $34 \mathrm{p}$.

Erickson, R.M., and Cotter, R.D., 1983, Trends in ground-water levels in Wisconsin through 1981: Wisconsin Geological and Natural History Survey Information Circular 43, $139 \mathrm{p}$.

Novitzki, R.P., 1982, Hydrology of Wisconsin Wetlands: Wisconsin Geological and Natural History Survey Information Circular 40, $22 \mathrm{p}$.

Kammerer, Phil A., Jr., Ground-water quality atlas of Wisconsin: Wisconsin Geological and Natural History Survey Information Circular 39, $39 \mathrm{p}$.

Young, H.L., and Batten, W.G., 1980, Ground-water resources and geology of Washington and Ozaukee Counties, Wisconsin: Wisconsin Geological and Natural History Survey Information Circular 38, 37 p.

Harr, C.A., Trotta, L.C., and Borman, R.G., 1978, Ground-water resources and geology of Columbia County, Wisconsin: Wisconsin Geological and Natural History Survey Information Circular 37, $30 \mathrm{p}$.

Hindall, S.M., 1978, Effects of irrigation on water quality in the sand plain of central Wisconsin: Wisconsin Geological and Natural History Survey Information Circular 36, $50 \mathrm{p}$.

Borman, R.G., 1976, Ground-water resources and geology of Walworth County, Wisconsin: Wisconsin Geological and Natural History Survey Information Circular 34, 45 p.

Borman, R.G., and Trotta, L.C., 1976, Ground-water resources and geology of Jefferson County, Wisconsin: Wisconsin Geological and Natural History Survey Information Circular 33, 31 p.

Borman, R.G., 1976, Ground-water resources and geology of St. Croix County, Wisconsin: Wisconsin Geological and Natural History Survey Information Circular 32, $30 \mathrm{p}$.

Bell, E.A., and Hindall, S.M., 1975, The availability of ground water for irrigation in the Rice Lake-Eau Claire area, Wisconsin: Wisconsin Geological and Natural History Survey Information Circular 31, 65 p.

McLeod, R.S., 1975, A digital-computer model for estimating hydrologic changes in the aquifer system in Dane County, Wisconsin: Wisconsin Geological and Natural History Survey Information Circular 30, 40 p.

Gonthier, J.B., 1975, Ground-water resources of Waukesha County, Wisconsin: Wisconsin Geological and Natural History Survey Information Circular 29, $47 \mathrm{p}$.

McLeod, R.S., 1975, A digital-computer model for estimating drawdown in the sandstone aquifer in Dane County, Wisconsin: Wisconsin Geological and Natural History Survey Information Circular 28, 91 p.

Holt, C.L.R., Jr., and Skinner, E.L., 1973, Ground-water quality in Wisconsin through 1972: Wisconsin Geological and Natural History Survey Information Circular 22, 148 p.

Erickson, R.M., 1972, Trends in ground-water levels in Wisconsin, 1967-71: Wisconsin Geological and Natural History Survey Information Circular 21, 40 p. (Supplement to Information Circular 9).
Holt, C.L.R., Jr., Cotter, R.D., Green, J.H., and Olcott, P.G., 1970, Hydrogeology of the Rock-Fox River basin of southeastern Wisconsin: Wisconsin Geological and Natural History Survey Information Circular 17, 47 p. (Prepared for the Annual Meeting of the Geological Society of America-Field Trip Guidebook).

Devaul, R.W., 1967, Trends in ground-water levels in Wisconsin through 1966: Wisconsin Geological and Natural History Survey Information Circular 9, $109 \mathrm{p}$.

Ryling, R.W., 1961, A preliminary study of the distribution of saline water in the bedrock aquifers of eastern Wisconsin: Wisconsin Geological and Natural History Survey Information Circular 5, $23 \mathrm{p}$.

Drescher, W.J., 1956, Ground water in Wisconsin: Wisconsin Geological and Natural History Survey Information Circular 3, 37 p.

1955, Some effects of precipitation on ground water in Wisconsin: Wisconsin Geological and Natural History Survey Information Circular 1, $17 \mathrm{p}$.

\section{WISCONSIN GEOLOGICAL AND NATURAL HISTORY SURVEY MISCELLANEOUS PAPERS}

Patterson, G.L., 1989, Water resources of Vilas County, Wisconsin: Wisconsin Geological and Natural History Survey Miscellaneous Paper 89-1, 46 p.

\section{OTHER PUBLICATIONS}

Hunt, Randy and Zheng, Chunmiao, 1999, Newsletter: Debating complexity in modeling; Eos, Transactions, American Geophysical Union, v. 80, no. 3, p. 29.

Hunt, R.J., Walker, J.F., and Krabbenhoft, D.P., 1999, Characterizing hydrology and the importance of ground-water discharge in natural and constructed wetlands: Wetlands, no. 19, v. 2, p. 458-472.

Lathrop, R.C., Carpenter, S.R., and Robertson, D.M., 1999, Summer water clarity responses to phosphorus, Daphnia grazing, and internal mixing in Lake Mendota: Limnology and Oceanography, v. 44 , no. 1, p. $137-146$

Panuska, J.C., and Robertson, D.M., 1999, Estimating phosphorus concentrations following alum treatment using apparent settling velocities: Lakes and Reservoir Management, v. 15, no. 1, p. 28-38.

Cleckner, Lisa B., Garrison, Paul J., Hurley, James P., Olson, Mark L., and Krabbenhoft, David P., 1998, Trophic transfer of methyl mercury in the northern Florida Everglades: Biogeochemistry, v. 40, p. 347-361.

Hunt, R.J., Anderson, M.P., and Kelson, V.A., 1998, Improving a complex finite difference groundwater-flow model through the use of an analytic element screening model: Ground Water, v. 36, no. 6 , p. 1011-1017.

Hunt, R.J., Bullen, T.D., Krabbenhoft, D.P., and Kendall, C., 1998, Using stable isotopes of water and strontium to investigate the hydrology of a natural and constructed wetland: Ground Water, v. 36 , no. 3 , p. $434-443$.

Hurley, James P., Krabbenhoft, David P., Cleckner, Lisa B., Olson, Mark L., Aiken, George R., and Rawlik Jr., Peter S., 1998, System controls on the aqueous distribution of mercury in the northern Florida Everglades: Biogeochemistry, v. 40, p. 293-311.

Krabbenhoft, David P., Gilmour, Cynthia C., Benoit, Janina M., Babiarz, Christopher L., Andren, Anders W., and Hurley, James P., 1998, Methyl mercury dynamics in littoral sediments of a temperate seepage lake: Canadian Journal of Fisheries and Aquatic Sciences, v. 55 , no. 4 , p. 835-844. 
Krabbenhoft, David P., Hurley, James P., Olson, Mark L., and Cleckner, Lisa B., 1998, Diel variability of mercury phase and species distributions in the Florida Everglades: Biogeochemistry, v. 40, p. 311-325.

Peters, C.A., and others, 1998, Water-quality in the western Lake Michigan drainages, Wisconsin and Michigan, 1992-95: U.S. Geological Survey Circular 1156, $40 \mathrm{p}$.

Robertson, D.M., Elder, J.F., Goddard, G.L., and James, W.F., 1998, Dynamics in phosphorus retention in wetlands upstream of Delavan Lake, Wisconsin: Lakes and Reservoir Management, v. 14, no. 4 , p. 466-477.

Schindler, John E., and Krabbenhoft, David P., 1998, The hyporheic zone as a source of dissolved organic carbon and carbon gases to a temperate forested stream: Biogeochemistry, v. 43, p. 157-174.

Team for Evaluating the Wisconsin Water-Monitoring Network, 1998, An integrated water-monitoring network for Wisconsin: University of Wisconsin Water Resources Center Special Report WRC SR 98-01, $62 \mathrm{p}$

Thorstenson, Donald C., Weeks, Edwin P., Haas, Herbert, Busenberg, Eurybiades, Plummer, L. Niel., and Peters, Charles A., 1998, Chemistry of unsaturated zone gases sampled in open boreholes at the crest of Yucca Mountain, Nevada: Data and basic concepts of chemical and physical processes in the mountain: Water Resources Research, v. 34 , no. 6, p. 1507-1529.

Walker, J.F., and Krabbenhoft, D.P., 1998, Groundwater and surfacewater interactions in riparian and lake-dominated systems in McDonnell, J.J., and Kendall, C., eds., Isotopic tracers in catchment hydrology: Elsevier, Amsterdam, The Netherlands, p. 467-486.

Fitzgerald, S.A., and Steuer, J.J., 1997, Polychlorinated biphenyls (PCBs) as probes of biogeochemical processes in rivers, in Molecular Markers in Environmental Geochemistry, Eganhouse, R.P., ed.: American Chemical Sociey Symposium Series, p. 382397.

Fitzgerald, S.A., and Steuer, J.J., 1997, Polychlorinated biphenyls (PCBs) as probes of biogeochemical processes in rivers, American Chemical Society Annual Meeting, Orlando, Florida, August 1996.

Hornewer, N.J., Johnson, G.P., Robertson, D.M., and Hondzo, M., 1997, Field-scale tests for determining mixing patterns associated with coarse-bubble air diffuser configurations, Egan Quarry, Illinois, in Environmental and Coastal Hydraulics: Protecting the Aquatic Habitat, proceedings of the International Association of Hydraulic Research, San Francisco, CA, USA, p. 57-63.

Hunt, R.J., Krabbenhoft, D.P., and Anderson, M.P., 1997, Assessing hydrogeochemical heterogeneity in natural and constructed wetlands: Biochemistry, v. 39, p. 271-293.

Olson, M.L., Cleckner, LB., Hurley, J.P., Krabbenhoft, D.P., and Heelan, T.W., 1997, Resolution of matrix effects on analysis of total and methyl mercury in aqueous samples from the Florida Everglades: Fresenius Journal of Analytical Chemistry, v. 358, p. 392-396.

Robertson, D.M., 1997, Regionalized loads of sediment and phosphorus to Lakes Michigan and Superior - High flow and long-term average: Journal of Great Lakes Research, v. 23, p. 416-439.

Walker, J.F., and Wang, D., 1997, Measurement of flow under ice covers in North America: Journal of Hydraulic Engineering, v. 123, no. 11 , p. $1037-1040$
Anderson, W.L., Robertson, D.M., and Magnuson, J.J., 1996, Evidence of recent warming and El Nino-related variation in ice breakup of Wisconsin lakes: Limnology and Oceanography, v. 41 , p. $815-$ 821 .

Bullen, T.D., Krabbenhoft, D.P., and Kendall, C., 1996, Kinetic and mineralogic controls on the evolution of groundwater chemistry and ${ }^{87} \mathrm{Sr}{ }^{86} \mathrm{Sr}$ in a sandy silicate aquifer, northern Wisconsin: Geochemica Cosomchemica Acta, v. 60, p. 1807-1821

Elder, J.F., James, R.V., and Steuer, J.J., 1996, Mobility of 2,2',5,5'tetrachlorobiphenyl in model systems containing bottom sediments and water from an industrialized river basin in northeastern Wisconsin: Journal of Great Lakes Research, v. 22, no. 3, p. 697706.

Gebert, Warren A. and Krug, William R., 1996, Streamflow trends in Wisconsin's driftless area: Journal of the American Water Resources Association, v. 32, no. 4, p. 733-744.

Hunt, R.J., Krabbenhoft, D.P., and Anderson, M.P., 1996, Groundwater inflow measurements in wetland systems: Water Resources Research, v. 32, no. 3, p. 495-507.

Hunt, R.J., and Krohelski, J.T., 1996, The application of an analytic element model to investigate ground-water lake interactions at Pretty Lake, Wisconsin: Journal of Lakes and Reservoir Management, v. 12 , no. 4 , p. $487-495$.

Imberger, J., Robertson, D.M., and Boland, K., 1996, Lake Number A quantitative indicator of mixing to be used in water quality management: ScientificImpeller, Solna, Sweden, no. 4, p. 9-15.

Klump, J.V., Edgington, D.N., Sager, P.E., and Robertson, D.M., 1996 The bigeochemistry of Green Bay - 1. Sedimentary phosphorus cycling in a phosphorus mass balance for the Green Bay ecosystem: Canadian Journal of Fisheries and Aquatic Sciences, v. 54, no. 1, p. 10-26.

Krug, William R., 1996, Simulation of temporal changes in rainfallrunoff characteristics, Coon Creek Basin, Wisconsin: Journal of the American Water Resources Association, v. 32, no. 4, p. 745752 .

Assel, Raymond A., and Robertson, Dale M., 1995, Changes in winter air temperatures near Lake Michigan, 1851-1993, as determined from regional lake-ice records: limnology and Oceanography, v. 40 , no. 1, January 1995 , p. $165-176$

Assel, R.A., Robertson, D.M., Hoff, M.H., and Selgeby, J.H., 1995, Climatic-change implications from long-term (1823-1994) ice records near the Laurention Great Lakes: Annals of Glaciology, v. 21 , p. $383-386$.

Greb, Steven R., and Graczyk, David J., 1995, Frequency duration analysis of dissolved-oxygen concentrations in two southwestern Wisconsin streams: Water Resources Bulletin, American Water Resources Association, v. 31, no. 3, June 1995, p. 431-438.

Kendall, C., and Krabbenhoft, D.P., 1995, Applications of isotopes to tracing sources of solutes and water in shallow systems in Charbeneau, R.J., ed., Groundwater Management, proceedings of the international symposium, August 1995, San Antonio, Tx, American Association of Civil Engineers, p. 390-395.

Krabbenhoft, David P., Benoit, Janina M., Babiarz, Christopher L., Hurley, James P., and Andren, Anders W., 1995, Mercury cycling in the Allequash Creek watershed, northern Wisconsin: Water, Air, and Soil Pollution, v. 80, nos. 1/4, February 1995, p. 425-433.

Krabbenhoft, David P., and Webster, Katherine E., 1995, Transient hydrogeological controls on the chemistry of a seepage lake: Water Resources Research, v. 31, no. 9, September 1995, p. 2295-2305. 
Velleux, Mark, Endicott, Douglas, Steuer, Jeffrey, Jaeger, Steven, and Patterson, Dale, 1995, Long-term simulation of PCB export from the Fox River to Green Bay: Journal of Great Lakes Research, International Association for Great Lakes Research, v. 21, no. 3, 1995 , p. 359-372.

Wentz, Dennis A., Rose, William J., and Webster, Katherine E., 1995 , Long-term hydrologic and biogeochemical responses of a soft water seepage lake in north central Wisconsin: Water Resources Research, v. 31, no. 1, January 1995, p. 199-212.

Elder, John F., 1994, Distribution and grain-size partitioning of metals in bottom sediments of an experimentally acidified Wisconsin lake: Water Resources Bulletin, v. 30, no. 2, p. 251-259.

Hurley, J.P., Krabbenhoft, D.P., Babiarz, C.L., and Andren, A.W., 1994, Cycling processes of mercury across sediment/water interfaces in seepage lakes in Baker, L.A., ed., Environmental Chemistry of Lakes and Reservoirs: Advances in Chemistry Series, American Chemical Society, Washington, D.C., p. 426-449.

Krabbenhoft, David P., Bowser, Carl J., Kendall, Carol, and Gat, Joel R., 1994, Use of oxygen-18 and deuterium to assess the hydrology of groundwater/lake systems in Baker, L.A., ed., Environmental Chemistry of Lakes and Reservoirs: Advances in Chemistry Series, American Chemical Society, Washington, D.C., p. 67-90.

Robertson, D.M., Anderson, W., and Magnuson, J.J., 1994, Relations between El Nino/Southern Oscillation events and the climate and ice cover of lakes in Wisconsin, p. 48-57. in Greenland, D. ed., El Nino and Long-Term Ecological Research (LTER) Sites, Publication no. 18, LTER Network Office: University of Washington, Seattle, WA, $57 \mathrm{p}$.

Robertson, D.M. and Imberger, J., 1994, Lake Number, a quantitative indicator of mixing used to estimate changes in dissolved oxygen. Internationale Revue der gesamten: Hydrobiologie, v. 79, p. $159-176$

Teal, M.J., Ettema, R., and Walker, J.F., 1994, Estimation of mean flow velocity in ice-covered channels: Journal of Hydraulic Engineering, v. 120 , no. 12 , p. 1385-1400.

Walker, John F., 1994, Methods for measuring discharge under ice cover: Journal of Hydraulic Engineering, v. 120, no. 11, p. 1327 1336.

Walker, John F., 1994, Statistical techniques for assessing water-quality effects of BMPs: Journal of Irrigation and Drainage Engineering, v. 120 , no. 2 , p. 334-347.

Bannerman, R.T., Owens, D.W., Dodds, R.B., and Hornewer, N.J. 1993, Sources of pollutants in Wisconsin stormwater: Water Science Technology, v. 28 , no. $3-5$, p. 241-259.

Fitzgerald, S.A., and Gardner, W.S., 1993, An algal carbon budget for pelagic/benthic coupling in Lake Michigan: Limnology and Oceanography, v. 28 , no. 3 , p. 547-560.

Walker, John F., and Graczyk, David J., 1993, Preliminary evaluation of effects of best management practices in the Black Earth Creek, Wisconsin, priority watershed: Water Science Technology, v. 28 no. 3-5, p. 539-548.

Assel, R.A. and Robertson, D.M., 1992, Climatic changes near the Great Lakes inferred from 141-year ice records in proceedings of the 5th International Meeting on Statistical Climatology, Toronto, Canada, June, p. 81-85.

Krabbenhoft, D.P., Anderson, M.P., and Bowser, C.J., 1992, Reply to comment by Stauffer on "Estimating groundwater exchange with lakes using stable isotopes:" Water Resources Research, v. 28, no. 6, p. 1751-1753.
Krabbenhoft, D.P., and Babiarz, C.L., 1992, Role of groundwater transport in aquatic mercury cycling: Water Resources Research, v. 28 , no. 12 , p. $3119-3128$.

Luecke, C., Lunte, C.C., Wright, R.A., Robertson, D.M., and McLain, A.S., 1992, Impacts of variation in planktivorous fish on abundance of Daphnids: A simulation model of the Lake Mendota Food Web, in Kitchell, J.F. ed., Food Web Management - A Case Study of Lake Mendota: Springer-Verlag, New York, NY, 553 p.

Robertson, D.M., Ragotzkie, R.A., and Magnuson, J.J., 1992, Lake ice records used to detect historical and future climatic changes: Climatic Change, v. 21, p. 407-427.

Elder, J.F., and Collins, J.J., 1991, Freshwater molluscs as indicators of bioavailability and toxicity of metals in surface-water systems: Reviews of Environmental Contamination and Toxicology, v. 122 , no. 4 , p. $37-79$

Walker, J.F., 1991, Accuracy of selected techniques for estimating iceaffected streamflow: Journal of Hydraulic Engineering, v. 117, no. 6 , p. 697-712.

Krabbenhoft, D.P., Anderson, M.P., and Boswer, C.J., 1990, Estimating groundwater exchange with lakes, 2 - Calibration of a threedimensional, solute transport model to a stable isotope plume: Water Resources Research, v. 26, no. 10, p. 2445-2462.

Krabbenhoft, D.P., Bowser, C.J., Anderson, M.P., and Valley, J.W., 1990, Estimating groundwater exchange with lakes, 1 - Use of the stable isotope method: Water Resources Research, v. 26, no. 10 , p. $2445-2453$.

Lodge, D.M., Krabbehoft, D.P., and Striegl, R.G., 1989, Groundwater velocity and abundance of grazing of crayfish as predictors of submersed macrophyte biomass in Sparkling Lake, Wisconsin: Limnology and Oceanography, v. 34, no. 1, p. 235-239.

Walker, J.F., Pickard, S.A., and Sonzogni, W.C., 1989, Spreadsheet watershed modeling for nonpoint-source pollution management in a Wisconsin basin: Water Resources Bulletin, v. 25, no. 1 , p. $139-147$

Wentz, D.A., Garrison, P.J., and Bockheim, J.G., 1989, Section 7 Chemical input-output budgets, in Knauer, D., and Brouwer, S.A., eds., The Wisconsin Regional Integrated Lake-Watershed Acidification Study (RILWAS): 1981-1983: Palo Alto, California, Electric Power Research Institute Report EA-6214, p. 7-1 to 7-30.

Wentz, D.A., and Rose, W.J., 1989, Interrelationships among hydrologic-budget components of a northern Wisconsin seepage lake and implications for acid-deposition modeling: Archives of Environmental Contamination and Toxicology, v. 18, p. 147-155.

Wentz, D.A., Rose, W.J., and Krohelski, J.T., 1989, Section 5-Hydrologic component, in Knauer, D., and Brouwer, S.A., eds., The Wisconsin Regional Integrated Lake-Watershed Acidification Study (RILWAS): 1981-1983: Palo Alto, California, Electric Power Research Institute Report EA-6214, p. 5-1 to 5-77.

Rochelle, B.P., Church, M.R., Gebert, W.A., Graczyk, D.J., and Krug, W.R., 1988, Relationship between annual runoff and watershed area for the eastern United States: Water Resources Bulletin, v. 24 , no. 1 , February 1988 , p. $35-41$.

Walker, J.F., 1988, General two-point method for determining velocity in open channel: ASCE Journal of Hydraulic Engineering, v. 114, no. 7, p. 801-805.

Graczyk, D.J., 1980, Flood insurance study of Verona, Dane County, Wisconsin, 3 fig., 3 pls. 
Grant, R.S., and Graczyk, D.J., 1979, Flood insurance study of Hayward, Sawyer County, Wisconsin, $42 \mathrm{p}$.

Graczyk, D.J., 1978, Flood insurance study of Marathon City, Marathon County, Wisconsin, 1 fig., 3 pls.

Graczyk, D.J., 1978, Flood insurance study of Athens, Marathon County, Wisconsin, 3 figs., 3 pls. 


\section{WISCONSIN DISTRICT PERSONNEL}

\section{DISTRICT OFFICE-MIDDLETON 53562}

8505 Research Way

Phone: (608) 828-9901

FAX: (608) 821-3817

Office Hours: 0800 to 1630

\section{Office of the District Chief}

Gebert, Warren A., District Chief

(608) 821-3801 (wagebert@usgs.gov)

Elder, John F., Research Hydrol/Biol

(608) 821-3854

\section{Administrative Services Unit \\ Grover, Richard L., Admin Off \\ (608) 821-3803 (rlgrover@usgs.gov) \\ Maertz, Diane E., Admin Opers Asst \\ (608) 821-3801 \\ Fuller, Jan M., Admin Opers Asst \\ (608) 821-3802 \\ Wolf, Julie A., Admin Opers Asst \\ (608) 821-3804}

Moore, Merry E., Admin Opers Asst

(608) 828-9901 or 0

\section{Computer Applications Unit}

Bodoh, Robert B., Comp Prog Analyst (608) 821-3805 (rbbodoh@usgs.gov)

Gill, Gary W., Comp Asst

(608) 821-3866

\section{Publications Unit}

Greenwood, Michelle M., Chief, Pub Unit (608) 821-3812 (mmgreenw@usgs.gov) Jones, Susan Z., Edit Asst

(608) $821-3815$

\section{Environmental Studies Section}

Hughes, Peter E., Chief Supv Hydrol/Biol (608) 821-3833 (pehughes@usgs.gov)

Walker, John F., Research Hydrol/Engr (608) 821-3853

Graczyk, David J., Hydrol/For

(608) 821-3840

Hall, David W., Hydrol

(608) 821-3875

Krug, William R., Hydrol/Engr

(608) 821-3829

Steuer, Jeffrey J., Hydrol/Eng

(608) 821-3830

Corsi, Steven R., Hydrol/Eng

(608) 821-3835

House, Harold R., Hydrol/Eng

(608) 821-3876

Owens, David W., Hydr Engr

(608) 821-3863

Stuntebeck, Todd D., Phys Sci

(608) 821-3872

\author{
Waschbusch, Robert J., Hydrol \\ (608) 821-3868 \\ Booth, Nathaniel, Hydr Eng \\ (608) 821-3822 \\ Selbig, Willaim, Hydrol \\ (608) 821-3823 \\ Goddard, Gerald L., Hyd Tech \\ (608) 821-3841 \\ Hanson, Halward L., Hyd Tech \\ (608) 821-3862 \\ Housner, David E., Hyd Tech \\ (608) 827-6255, ext. 15 \\ Rutter, Troy D., Hyd Tech \\ (608) 821-3848 \\ Wierl, Judy A., Hydr Eng \\ (608) 821-3874
}

\author{
Hydrogeologic Studies and Data Section \\ Krohelski, James T., Chief Supv Hydrol \\ (608) 821-3850 (jtkrohel@usgs.gov) \\ (608) 821-3843 \\ Hunt, Randall J., Hydrol/Geol \\ (608) 821-3847 \\ Feinstein, Daniel T., Hydrol \\ (414) 297-3172 \\ Olson, Mark L., Biol \\ (608) 821-3878 \\ Ellefson, Bernard R., Hyd Tech \\ (608) 821-3849 \\ Dunning, Charles D., Physical Scientist \\ (608) 821-3827 \\ DeWild, John F., Hyd Tech \\ (608) 821-3846 \\ Rauman, James M., Hyd Tech \\ (608) 821-3871
}

Krabbenhoft, David P., Research Hydrol/GeoChem

Hydrologic Systems and Data Section

Garn, Herbert, Chief Supv Hydrol

(608) 821-382,8 (hsgarn@usgs.gov)

Rose, William J., Hydrol/Engr

(608) 821-3834

Holmstrom, Barry K., Hydrol/Engr

(608) 821-3831

Olson, Daniel L., Hyd Tech

(608) 821-3852

Homant, Paulette, Hyd Tech

(715) 356-9494

Stark, Patricia A., Hyd Data Asst

(608) 821-3838 
National Water Quality Assessment Program

Peters, Charles A., Chief Supv Hydrol

(608) 821-3810 (capeters@usgs.gov)

Fitzgerald, Sharon A., Research Hydrol/Biol (787) 749-4346, ext. 252

Robertson, Dale P., Research Hydrol/Chem (608) 821-3867

Fitzpatrick, Faith A., Hydrol

(608) 821-3818

Sullivan, Daniel J., Hydrol

(608) 821-3869

Scudder, Barbara C., Research Hydrol/Biol (608) 821-3832

Saad, David A., Hydrol/Geol

(608) 821-3865

Schmidt, Morgan, Hydrol

(608) 821-3820

Richards, Kevin E., Hyd Tech

(608) 821-3861

Stewart, Jana S., Geographer

(608) $821-3855$
FIELD HEADQUARTERS-MIDDLETON 53562

8551 Research Way, Suite 120

Phone: (608) 827-6255

Office Hours: 0800 to 1630

Habale, Josef, Hyd Tech, ext. 10

Koenig, Kenneth R., Hyd Tech, ext. 13

March, Steven A., Hyd Tech, ext. 12

Wittwer, Thomas A., Hyd Tech, ext. 14

FIELD HEADQUARTERS-RICE LAKE 54868

313 W. Knapp St., P.O. Box 506

Phone: (715) 234-4015

Office Hours: 0800 to 1630

Popowski, Thomas J., Hyd Tech

Schuler, Josef G., Hyd Tech

Lenz, Bernard, Hydraulic Engineer

FIELD HEADQUARTERS-MERRILL 54452

2011 East Main Street

Phone: (715) 536-2200

Office Hours: 0800 to 1630

Hanig, Jeffrey J., Hyd Tech

Esser, Brett M., Hyd Tech 